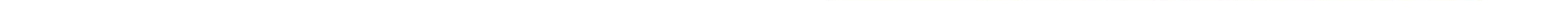


São Paulo

2012

MICHELE DE SÁ VIEIRA

\section{Entre as serras: Sistema de espaços livres públicos, uma reflexão para Suzano}

Dissertação apresentada ao Programa de Pós-Graduação da Faculdade de Arquitetura e Urbanismo da Universidade de São Paulo para a obtenção do título de Mestre em Arquitetura

Área de Concentração: Paisagem e Ambiente Orientador: Prof. Dr. Silvio Soares Macedo 
Autorizo a reprodução e divulgação total ou parcial deste trabalho, por qualquer meio convencional ou eletrônico, para fins de estudo e pesquisa, desde que citada a fonte.

e-mail da autora: michelesav@itelefonica.com.br

VIEIRA, Michele de Sá

V657s Entre as serras: Sistema de espaços livres públicos, uma reflexão para Suzano/ Michele de Sá Vieira. - São Paulo, 2012.

283 p. : il.

Dissertação (Mestrado - Área de Concentração: Paisagem e Ambiente) - FAUUSP. Orientador: Prof. Dr. Silvio Soares Macedo

1.Espaços livres - Sistemas 2.Políticas públicas 3.Ecologia da paisagem I.Título II.Título: Entre as serras: Sistema de espaços livres públicos, uma reflexão para Suzano 
Ao meu pai por ter me ensinado que o conhecimento traz a liberdade. 


\section{Agradecimentos}

0 desenvolvimento deste trabalho teve a contribuição de diversas pessoas que cercam a minha vida, tanto no convívio profissional, quanto na vida pessoal. A todos agradeço imensamente e ressalto algumas delas pela intensa paciência, amizade, incentivo, dedicação e amor:

Ao prefeito Marcelo de Souza Candido, pelas inúmeras oportunidades que me foram dadas, na Prefeitura Municipal de Suzano, as quais me possibilitaram um amplo desenvolvimento profissional.

A dois arquitetos da prefeitura, Elvis José Vieira, por todas as dúvidas sanadas ao longo do mestrado e conhecimentos passados durante o tempo em que trabalhamos juntos e Sanderlei Fernandes Vilanova, pelas suas várias contribuições desde o desenvolvimento do projeto de pesquisa até a conclusão da dissertação.

A amigos muito queridos que fazem parte da minha vida pessoal, em especial ao João Gabriel Dias Clemente, meu treinador de longas corridas, responsável pela minha constante disposição física e mental na elaboração deste projeto e, também, a três amigas, Solande Wuo, companheira dos desafios vinculados à temática ambiental; Maria Angélica Batista, principal incentivadora do meu mestrado na Universidade de Mogi das Cruzes, onde dou aulas; e Lilian Pachler, pelas incontáveis e agradáveis conversas.

À minha família, em especial, à minha mãe, aos meus irmãos e minhas avós, Tereza, Geralda (in memoriam) e Grizelides (in memoriam), que sempre participaram dos meus estudos.

Ao meu orientador, Silvio Soares Macedo, com muito carinho e admiração, pela sua intensa e extrema dedicação ao trabalho que elaboramos juntos, além de sua esposa, Jô Capitani, por me receber sempre de forma tão acolhedora em sua casa para o desenvolvimento das orientações.

Finalmente, ao meu marido e jornalista Pedro Carvalho Vieira, parceiro de todos os momentos, pela participação que teve nesta dissertação, pois afinal ele contribuiu com várias revisões, traduções, entre outros inúmeros aspectos, mas, principalmente, Ihe agradeço por toda a paciência, compreensão, amizade e amor, a mim dedicados ao longo dos nossos 23 anos de relacionamento. 


\section{Resumo/ Abstract}

VIEIRA, Michele de Sá. Entre as serras: Sistema de espaços livres públicos, uma reflexão para Suzano. 2012. XXX p. Dissertação (Mestrado) - Faculdade de Arquitetura e Urbanismo, Universidade de São Paulo. São Paulo, 2012.

0 trabalho reflete sobre a paisagem, o ambiente e os espaços livres de Suzano, município situado na bacia do Alto Tietê Cabeceiras, que faz parte da Região Metropolitana de São Paulo. Inicialmente, desenvolve-se a análise de conceitos voltados à ecologia de paisagens e do sistema de espaços livres públicos. Em seguida, faz-se uma aproximação da paisagem e do sistema de espaços livres do municipio, objetivando compreender a diversidade de suas paisagens, bem como do seu ambiente nos distritos que o compõem. Após esta compreensão retoma-se novamente o conceito voltado à ecologia de paisagens, para que este possa ser utilizado na constituição de uma proposta de sistema de espaços livres públicos para o território, buscando a valorização das suas paisagens, assim como do ambiente. Ao final, verifica-se quais são os entraves existentes na gestão pública, que dificultam a implementação de políticas ambientais no pais.

Palavras-chave: Sistema de espaços livres públicos; Políticas públicas; Ecologia de paisagens

The goal of this dissertation is to study the impact of landscape and open spaces on the environment in urban areas. The focus will be on the city of Suzano, which is located at the basin of Alto Tietê Cabeceiras and is part $f$ the metropolitan region of São Paulo, Brazil. The first part of the study will focus on ecological concepts of landscapes and open spaces of the city. After, we aim to better understand the diversity of the open spaces within these territories and how they shape and mold the terrain and effect the local environment. Once an informed and educated analysis is achieved, the goal is then to establish a proposal to implement an open space program for the surrounding Suzano area that would both bring better quality of life and value to the city and their inhabitants. Finally, we plan to point out what obstacles and barriers might exist in within the government for implementation of these policies.

Key words: Public open space systems; Public policy; Landscape ecology 
SUMÁRIO

Introdução

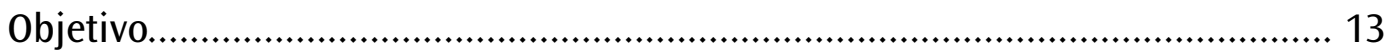

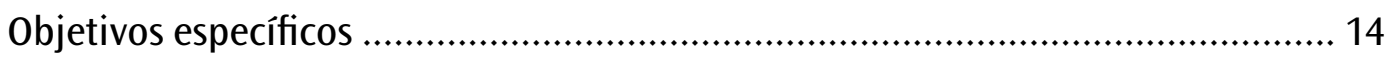

Estrutura da dissertação ……………………………………………………...... 16

Capítulo 1 - Potencialidades e conflitos: Uma aproximação conceitual e prática ..... 19

Paisagem: 0 conceito em questão ………………………………………........ 21

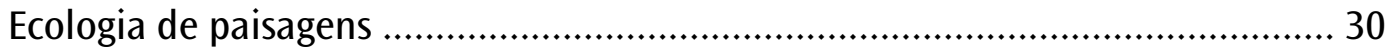

Dinâmica ambiental e urbanização: Introduzindo questões .................................. 36

A produção do espaço e os processos de urbanização e

degradação: Características gerais .................................................................. 46

Crescimento e desenvolvimento sustentável ....................................................... 50

Sistema de espaços livres públicos como elementos da

paisagem urbana: Conceitos ........................................................................... 59

Capítulo 2 - Compreendendo o sentido da paisagem ……………………………..... 91

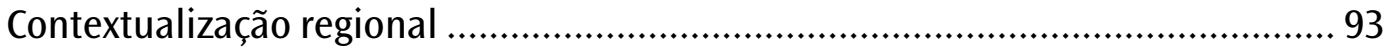

Contextualização territorial de Suzano ……………………………………..... 99

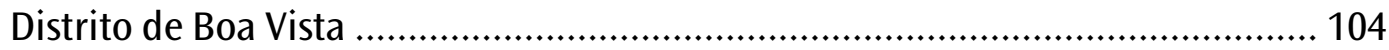

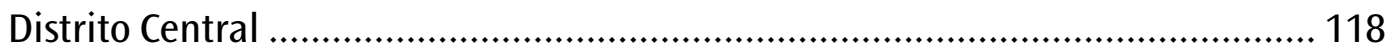

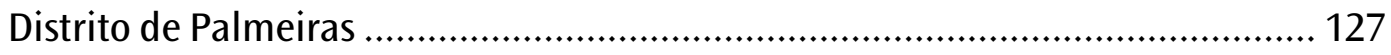

Urbanização em Área de Proteção dos Mananciais ............................................ 133

Capítulo 3 - Uma análise sobre as unidades de paisagens ............................................. 149

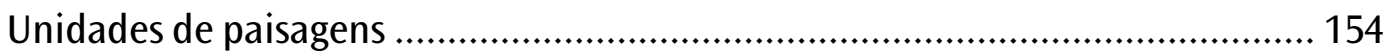

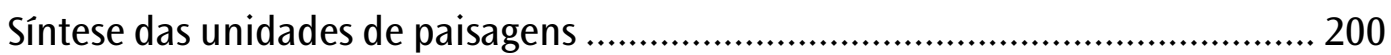


Capítulo 4 - A constituição do sistema de espaços livres públicos:

Uma reflexão sobre as possíveis conexões da paisagem ........................... 207

Conexões da paisagem: Conceitos e análises .................................................... 209

Sistema de espaços livres públicos: A constituição de cenários futuros ................ 231

Sistema de espaços livres públicos: Uma proposta para o território de Suzano... 241

Capítulo 5 - A gestão pública e os entraves para o alcance dos objetivos .................... 249

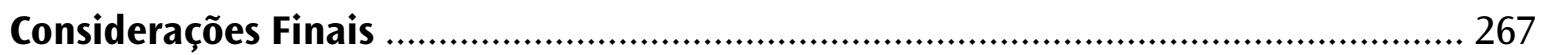

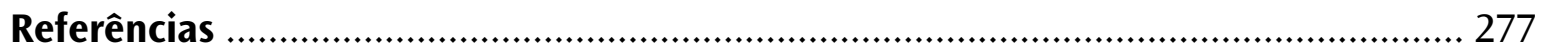

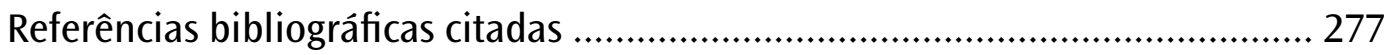

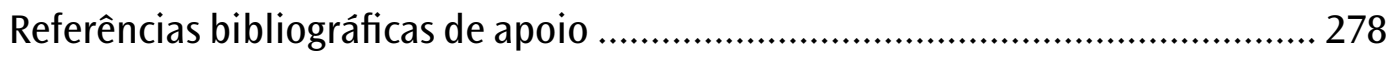

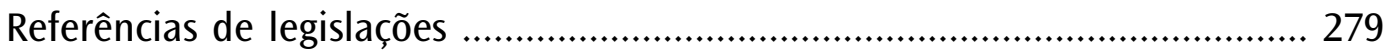

Referências de endereços eletrônicos ....................................................... 280

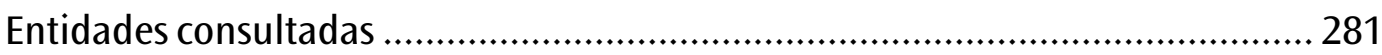

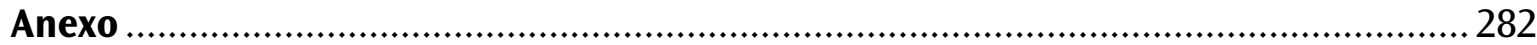





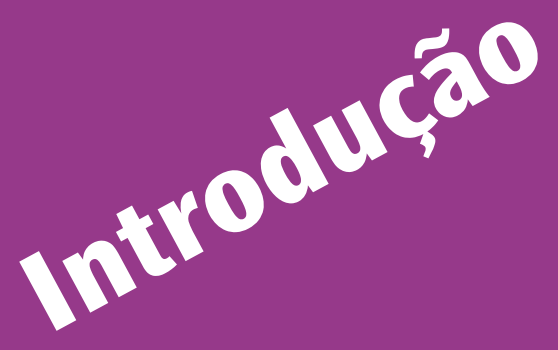





\section{Introdução}

Este é um trabalho que retrata a gestão da paisagem, da dinâmica ambiental sob o viés do paisagismo e, em especial, da ecologia da paisagem, além dos métodos, processos e fatos em andamento no município de Suzano, que se situa na Região Metropolitana de São Paulo.

A dissertação apresenta uma análise, investigativa e reflexiva, buscando em um primeiro instante situar o leitor, através da explicitação dos objetivos gerais e específicos e, também, da estruturação do trabalho que se divide em duas partes e cinco capítulos.

Para tanto, o estudo percorre um caminho que se inicia a partir de uma aproximação conceitual vinculada à paisagem e à ecologia de paisagens, posteriormente, aproxima-se do território verificando quais são as suas potencialidades e conflitos, buscando detalhá-los em um terceiro momento. Após a apropriação dos conceitos e do território faz-se uma proposta paisagística para o município, a qual visa a sua valorização a partir dos recursos ambientais, em especial dos florestais. Ao final, apresentamos como os diversos entraves existentes nas políticas públicas ambientais prejudicam e até mesmo impedem a implantação de um sistema de espaços livres públicos que se possa denominar como adequado para a cidade e o município.

Como elemento central da análise coloca-se que a urbanização, tradicionalmente, tem-se produzido de maneira a não contribuir para com a estabilidade do suporte físico e a dinâmica ecológica pré-existente. Dessa forma, entende-se que pelos diferentes lugares, as diversas formas ambientalmente inadequadas de 
ocupação do território brasileiro se repetem, tanto as de caráter rural, quanto as urbanas.

Isto se dá em função dos constantes processos de ocupação acontecerem em locais que deveriam ser preservados pelas ações do Poder Público, que ignoram situações de risco como estas, contribuindo dessa forma para com inúmeros desastres ambientais nos municípios, como os deslizamentos e as enchentes, além das perdas ambientais relacionadas à qualidade da água, aos desmatamentos acentuados, entre outros.

Observa-se que as áreas urbanas contribuem significativamente para com a instabilidade do suporte físico, na medida em que os rios, que se encontram nos espaços urbanizados, são canalizados, em sua maior parte, além de possuírem suas margens ocupadas pelo sistema viário ou construções.

Todos estes fatos acabam trazendo danos imensuráveis à população, já que interferem no cotidiano da sua vida e mesmo na continuidade dela, pois por vezes vidas são suprimidas em função dos desastres e das perdas ambientais.

0 que se observa é que as condições climáticas, o suporte físico, a biodiversidade, a vegetação, a estrutura do solo, bem como o sistema hídrico são ignorados nas ações por grande parte dos setores público e privado. Isto se dá por meio de ações como: a eliminação da vegetação para a implementação da agricultura e da urbanização, a extração de minério que leva a grandes movimentações de terra e o sistema hídrico reordenado para executar obras de todo porte, sendo eles suprimidos, extraídos e movimentados. 
Objetivo Geral

0 objetivo deste trabalho é a construção de uma análise territorial que compreende os processos e agentes que interferem na paisagem e no ambiente, dentro dos limites do município de Suzano, que está situado vizinho às serras do Itapety e do Mar, além de ser cortado por ampla área de várzea.

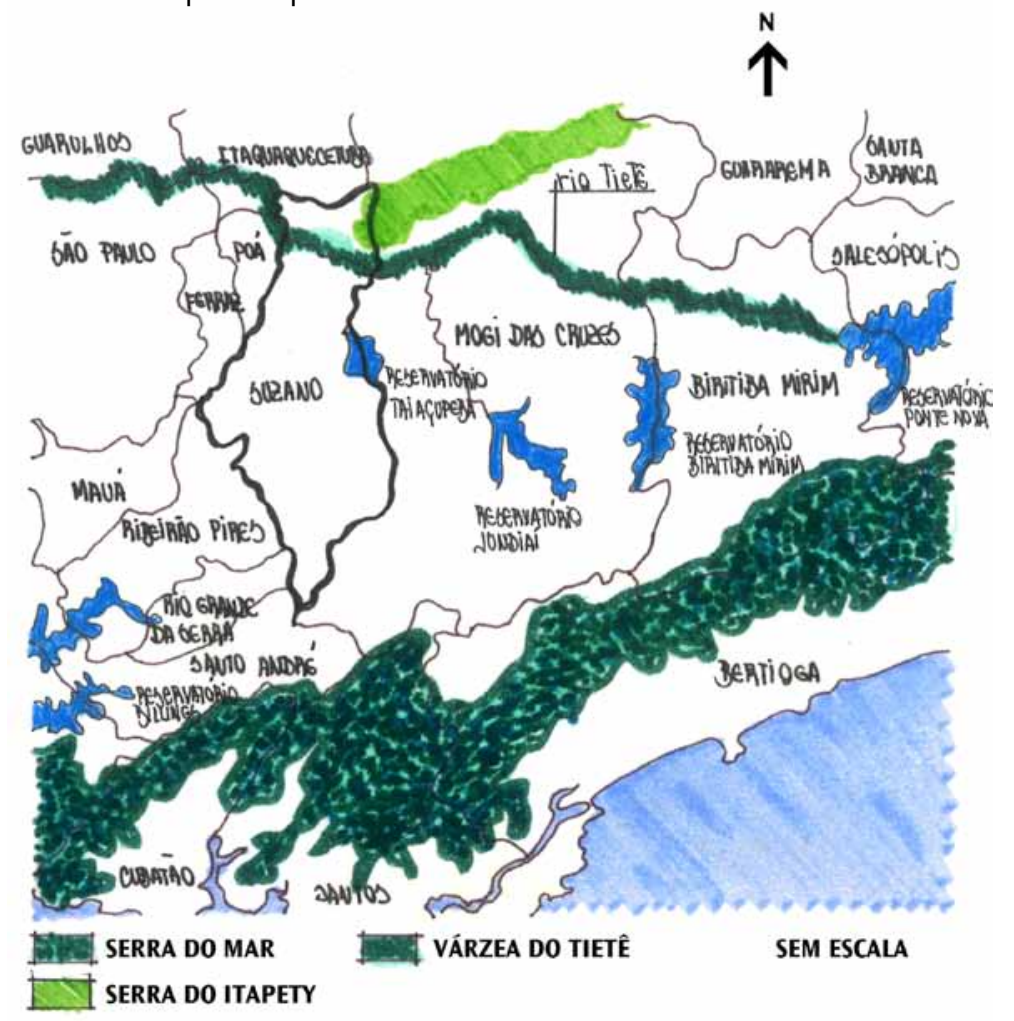

A análise é feita pela ótica da paisagem, dando-se ênfase aos princípios do planejamento da paisagem, à ecologia de paisagens, bem como à qualificação e incremento do sistema de espaços livres públicos.
Mapa que aponta as potencialidades ambientais existentes no território de Suzano, bem como no seu entorno - baseado em mapa da SOS Mata Atlântica, 2008; mapa dos Mananciais da Região Metropolitana de São Paulo, 2007; e mapa que demonstra as Áreas de Interesse Ambiental Especial da Secretaria Estadual de Meio Ambiente, 2000 Fonte: Desenho criado por Michele de Sá Vieira, 2011 


\section{Objetivos específicos}

IPara Metzger (2001), unidade da paisagem trata-se de cada tipo de componente da paisagem (unidades de recobrimento e uso do território, ecossistemas e tipos de vegetação, por exemplo).
0 trabalho desenvolve uma análise do território para verificar a viabilidade de criação de um sistema de espaços livres públicos capaz de promover a conectividade entre os diversos ecossistemas existentes, através da implementação de parques lineares e corredores ecológicos, perpassando por diversos objetivos específicos.

Dessa forma, tem-se como objetivo, o entendimento da apropriação do município de Suzano, através do conhecimento do seu ambiente, dos processos de ocupação, relatando seus conflitos, os benefícios que o território ainda guarda como as matas e a rede hidrica, que possuem papéis estruturantes em sua formação.

Compreende-se, também, através do viés da ecologia de paisagens, quais são as melhores estratégias para elevar os aspectos urbanisticos e ambientais do território, utilizando-se dos valores da natureza como as águas e as matas, para que o município possa ter qualidade de vida.

Com um olhar mais detalhado, aborda-se também objetivos específicos como a compreensão da paisagem do município, considerando que esta é formada por um "mosaico heterogêneo", composto por unidades da paisagem que podem ter a capacidade de se interconectar, possibilitando a restauração dos sistemas ecológicos e, consequentemente, o fluxo gênico, com a intenção de verificar a provável chance de recuperação das espécies endêmicas antes existentes nos locais de estudo!

Além disso, verificar as potencialidades ecológicas do sistema de espaços livres urbanos para que se possa trabalhar na conservação e regeneração dos recursos naturais existentes, tais como águas urbanas, vegetação, entre outros, a partir da compreensão 
do arranjo ideal do uso do solo na paisagem deste território, considerando-se os conceitos da ecologia de paisagens no que se refere à estrutura, função e mudança.

Nesta dissertação entende-se que os espaços livres públicos existentes, a exemplo dos sistemas de matas, viário e hídrico, podem evoluir para alcançar uma forma que seja capaz de resgatar as funções ecológicas e ainda colaborar para o desenvolvimento ambiental do município, econômico e cultural da sociedade local, através da implantação de um padrão morfológico, elaborado em conformidade com as estruturas ecológicas de cada lugar deste território.

Com relação à criação de políticas públicas, verifica-se em que medida o seu desenvolvimento pode ser aproveitado como fator indutor na constituição de um sistema de espaços livres públicos. Assim, sugere-se alguns espaços prioritários para que haja investimentos públicos, bem como de ações para a construção de cenários ideais voltados à implementação de um sistema, capaz de incorporar as caracteristicas, ambientais, ecológicas, paisagísticas e cênicas do território. 


\section{Estrutura da dissertação}

Estrutura-se em duas partes e cinco capitulos:

A primeira parte, denominada como Potencialidades e conflitos: Uma reflexão conceitual e prática da paisagem de Suzano, abrange os capitulos 1 e 2, perpassando inicialmente por uma análise conceitual e apropriando-se, em um segundo momento, das potencialidades e dos conflitos territoriais existentes, bem como suas interferências na paisagem de Suzano.

No Capítulo 1 - Potencialidades e conflitos: Uma aproximação conceitual e prática, apontamos as potencialidades ambientais, assim como os conflitos existentes no território, além de reunir algumas contribuições teóricas voltadas ao conceito de paisagem, ecologia de paisagem, produção do espaço, crescimento e desenvolvimento sustentável, além do sistema de espaços livres públicos.

No Capítulo 2 - Compreendendo o sentido da paisagem, entende-se a paisagem do município de Suzano, dentro da contextualização regional e local, considerando que esta é formada por um mosaico em transformação, composto por várzeas, áreas urbanizadas, agricultura, águas, fragmentos de mata nativa e florestas de eucalipto, distribuido por três distritos, cada qual com suas caracteristicas ambientais, sociais e culturais.

A segunda parte, denominada Novas estratégias de gestão para a valorização das potencialidades ecológicas, a qual compreende os capitulos 3, 4 e 5, investiga o município de Suzano de forma mais detalhada, de modo a incentivar a ampliação planejada do "Sistema de Espaços Livres Públicos", o qual terá como um 
dos seus objetivos propiciar a restauração ambiental, paisagística e ecológica do município, a partir de novas estratégias de gestão.

No Capítulo 3 - Uma análise sobre as unidades de paisagens, o território foi subdividido em 10 unidades de paisagem, utilizando-se da similaridade e uniformidade com relação ao uso e ocupação do solo como critério para a subdivisão das unidades. Estas foram analisadas pelo viés de suas características, conflitos, previsão com relação aos cenários futuros possíveis, além do levantamento das principais ações públicas executadas entre os anos de 2005 a 2011, objetivando aprofundar as reflexões vinculadas às questões urbanísticas, paisagísticas e ambientais.

No Capítulo 4 - A constituição de um sistema de espaços livres públicos: Uma reflexão sobre as possíveis conexões da paisagem, indica-se de que maneira o sistema de espaços livres públicos, existente no município, poderá evoluir para alcançar uma forma capaz de resgatar as funções ecológicas e, ainda, colaborar para o desenvolvimento urbanístico e ambiental do território, através de uma proposta-síntese, pautada nos princípios da ecologia de paisagens.

No Capítulo 5 - A gestão pública e os entraves para o alcance dos objetivos, expõe-se uma análise crítica e reflexiva, quanto ao papel dos gestores públicos como autoridades municipais, que atuam em territórios que possuem características ambientais, ecológicas e paisagísticas especiais e, portanto, de grande valor, como é o caso do município de Suzano.

Assim, verifica-se em que medida a criação de políticas públicas podem trabalhar como fator indutor na implementação do sistema de espaços livres públicos não convencional. 
E, ainda, no sentido de aplicar o conhecimento posto no capitulo quatro, analisa-se a possibilidade de se implantar os parques lineares e os corredores ecológicos como uma nova estratégia para o municipio em análise. Dessa forma estabelece-se os parques lineares e corredores ecológicos como estratégias de gestão para a valorização do território. 


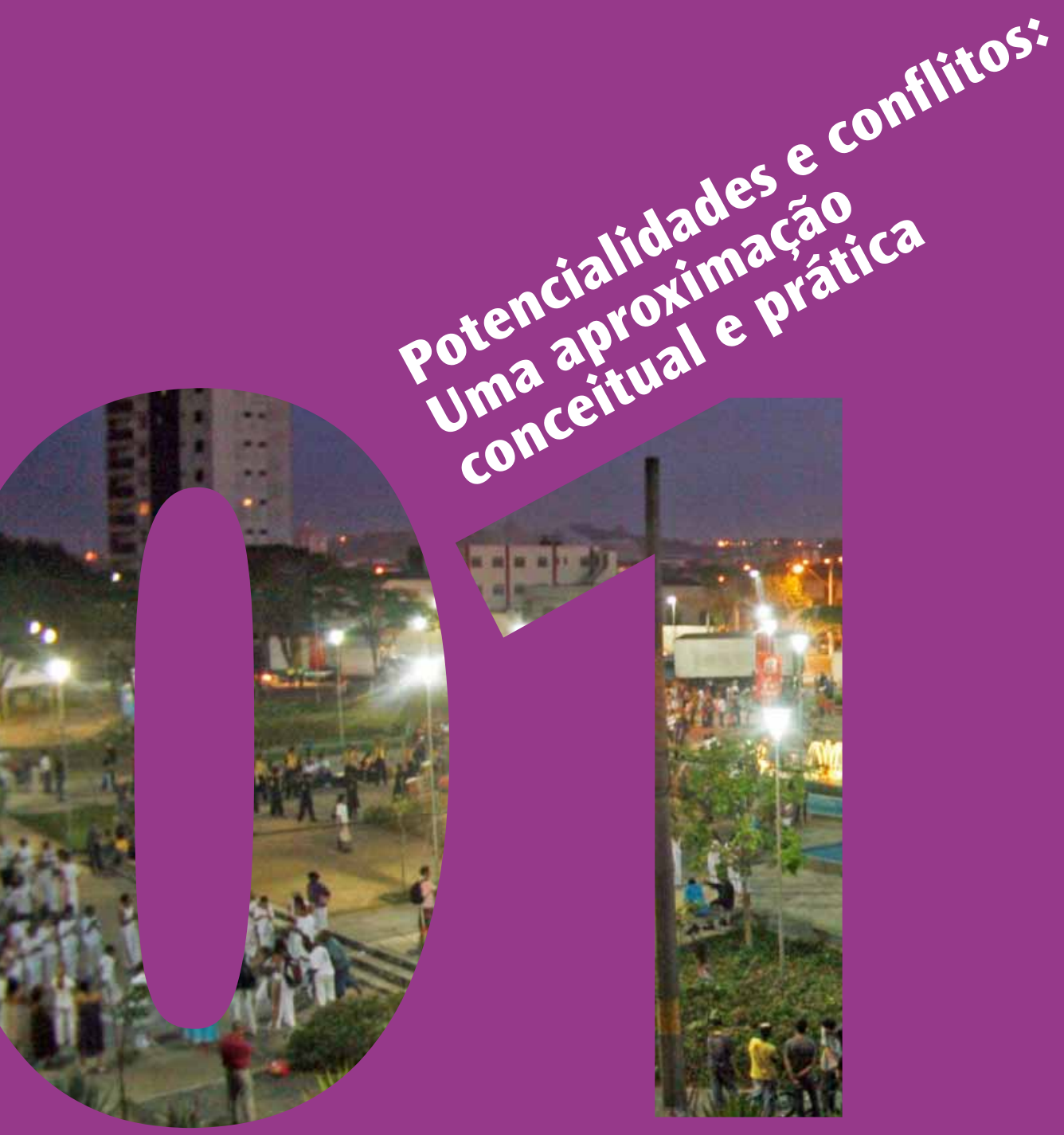





\section{Paisagem: 0 conceito em questão}

0 uso do termo 'paisagem' muitas vezes esteve relacionado com pinturas elaboradas a partir da natureza durante o período da Renascença, além disso pode significar também aquilo que o olhar abrange em um único golpe de vistal.

Inicialmente, dada sua conotação estética, o conceito era bastante interligado com o paisagismo e com a arte dos jardins. No entanto, a partir do século XIX, em decorrência do fato de possuir a capacidade de expressar as características de um lugar, a paisagem começa a ser considerada como um objeto a ser estudado nos trabalhos dos naturalistas e dos geógrafos ${ }^{2}$.

Ou seja, a forma dos campos, da vegetação, a importância do clima, bem como sua influência sobre os seres vivos, passam a ser consideradas dentro do conceito em questão.

A paisagem é compreendida como a própria expressão morfológica das estruturas físicas que se manifestam na natureza, variando conforme o solo, a cobertura vegetal, o sistema hídrico e o clima, o que acaba por caracterizar, dessa forma, seus aspectos espaciais.

Assim, possui a capacidade de expressar a aparência, bem como a representação de uma série de objetos visiveis dentro de uma região, de um território, onde se desenvolve a vida de comunidades humanas.

Além da premissa que a paisagem é uma estrutura física, que se manifesta através de sua imagem, entende-se que sua per-
I CHRISTOFOLETTI, A.. Modelagem de sistemas ambientais. São Paulo: Edgard Blucher, 1999. p. 38.

2 Ibid., p. 38. 
3 PELLEGRINO, P. R. M.. Paisagens

Temáticas: Ambiente virtual. Tese

(Doutorado) - Faculdade de Arquitetura e Urbanismo, Universidade de São Paulo. São Paulo, 1995.

4 Ibid., p. 12. cepção não é apenas visual, mas também olfativa, tátil, sonora e cinética ${ }^{3}$.

Uma outra perspectiva voltada ao conceito pode ser inspirada na Semiótica, que estabelece a paisagem como um fenômeno de comunicação e de percepção, enquanto forma de produção e informação. Ou seja, a paisagem passa a ser entendida enquanto um fenômeno que se apresenta através de símbolos, signos, sinais naturais e artificiais, alguns se caracterizando através de uma conformação delimitada e presença constante, enquanto outros pela instabilidade e presença transitória, todos em constante comunicação com os seres vivos ${ }^{4}$.

A paisagem é uma estrutura complexa, constituída por elementos não somente naturais, mas também por obras materiais e imateriais, executadas pela sociedade. Isto porque a composição da paisagem é entendida para além dos aspectos físicos, podendo ser expressa por valores culturais, comportamentos sociais, ações individuais coletivas e processos econômicos exercidos sobre lugares específicos por um determinado período.

Pelo fato da paisagem ir além dos aspectos físicos, ela passa a ser estudada sob o ponto de vista da análise territorial, por permitir um entendimento dos processos geradores desta paisagem, 0 que pode facilitar e balizar as ações públicas.

Assim, sua configuração se deve à interdependência entre os diversos elementos constituintes, sejam eles naturais ou materiais. A partir dessas variáveis é que sua forma, estrutura e funcionamento acontecem, estando ela sujeita a mudanças e aperfeiçoamentos.

Além disso, entender o processo de construção da paisagem significa apropriar-se do modo de produção do território, que se 
apresenta em relação ao modelo de desenvolvimento econômico impresso sobre ele, dentro de um recorte temporal.

A paisagem é um objeto dinâmico e não estável caracterizada pelas diversas formas de povoamento e apropriação do território que se transformam ao longo do tempo, a cada momento, resultando na paisagem contemporânea.

Esta paisagem é lida pelo olhar e pela percepção visual de cada observador que a interpretada dentro da sua escala, de acordo com o seu campo visual e segundo as suas limitações físicas, caracterizando-a como o modo de ver projetado na superfície da terra ${ }^{5}$.

Assim, é reveladora da sintese entre o tempo e o espaço, expressa pelas ideologias, transformações, reflexões, conflitos, contradições e adversidades que acontecem sobre o território, em função da interferência de diversos aspectos.

A paisagem, dessa forma, é um objeto que possui a capacidade de abrigar ações e/ou atividades humanas, tais como as ocupações que se dão ao longo do solo, que possibilitam estabelecer mudanças sobre ela através de modos de produção vinculados à indústria, ao comércio e à agricultura, produzindo, por sua vez, alterações e transformações diretas nos sistemas naturais.

Assim, ela é expressa por processos e não somente como um elemento representado por uma extensão de terra que guarda apropriações estéticas, sensoriais e visuais ${ }^{6}$. Estes processos podem ser sociais, promovendo relações de sociabilidade, enfim, atividades previstas no circuito social estimuladas pela gestão do território; econômicos, representados pelas intensas atividades industriais e comerciais que atuam na transformação, produção
5 MACEDO, S. S.. Paisagem, urbanização e litoral do éden à cidade. Tese (Livre-Docência) - Faculdade de Arquitetura e Urbanismo, Universidade de São Paulo. São Paulo, 1993. p. 11.

6 YÁZIGI, E.. Turismo e paisagem. São Paulo: Contexto, 2002. 


\section{Suzano: Taikô - Praça Cidade das Flores}

Fonte: Wanderley Costa - Prefeitura Municipal de Suzano, 2009 e reprodução da natureza em bens de consumo; e culturais, por possibilitar que a sociedade se expresse nos espaços através das manifestações artísticas, criando proximidade e identidade com 0 território, que se materializa pelas diversas edificações e costumes e que perpetuam ao longo do tempo, podendo ser transmitidos às gerações futuras.

Como exemplo, no município de Suzano, estas manifestações acontecem sob diversas formas demonstradas pelas imagens a seguir, como a apresentação do Taikô na praça, uma prática musical, percussiva, corporal e coletiva, que utiliza os tambores japoneses (taikô) como instrumentos principais. Outras formas de manifestação acontecem através dos quadros expostos nas calçadas, que permitem aos pedestres desfrutar da arte na rua, as rodas de capoeira, bem como a Roda de Todos os Santos.

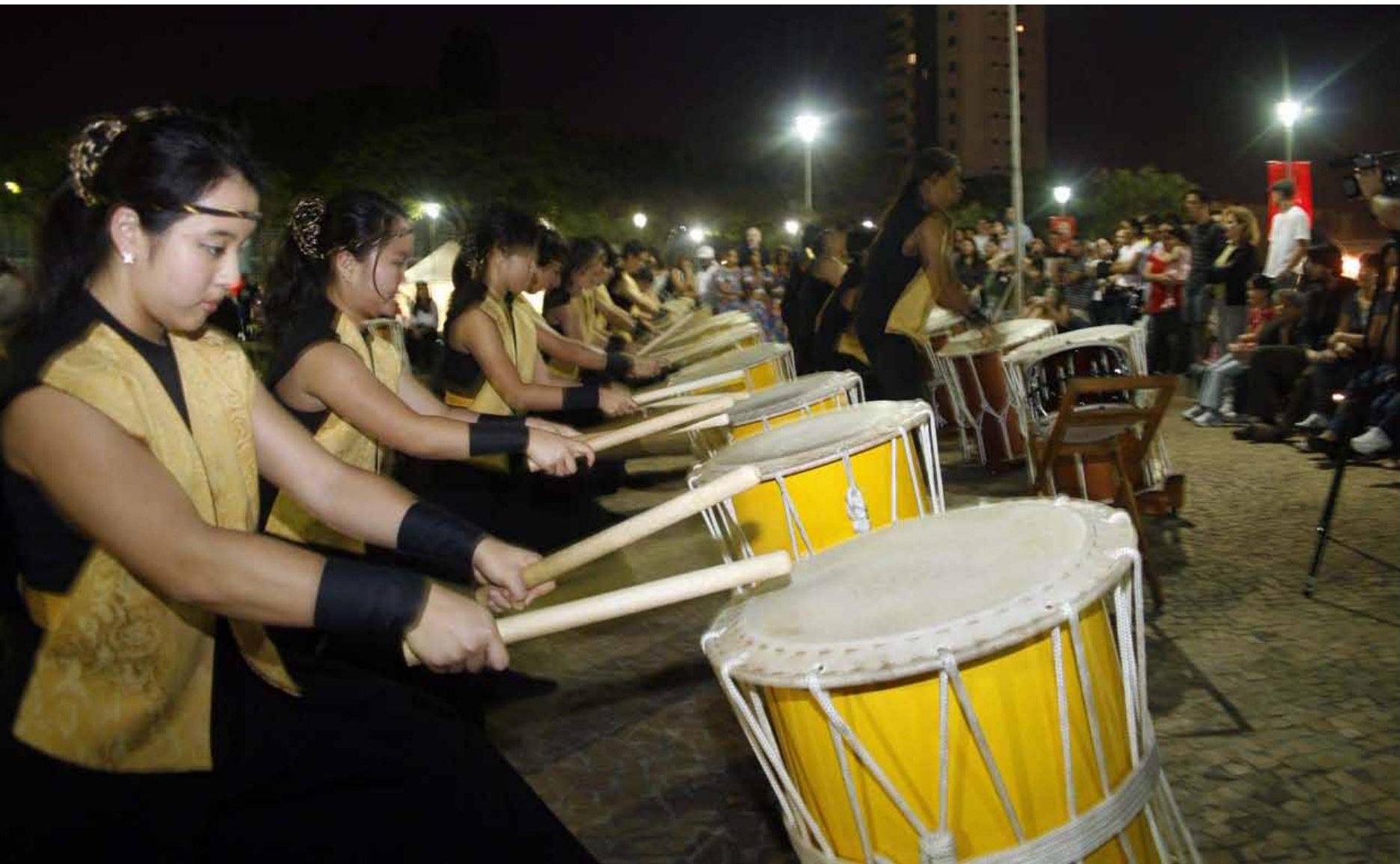




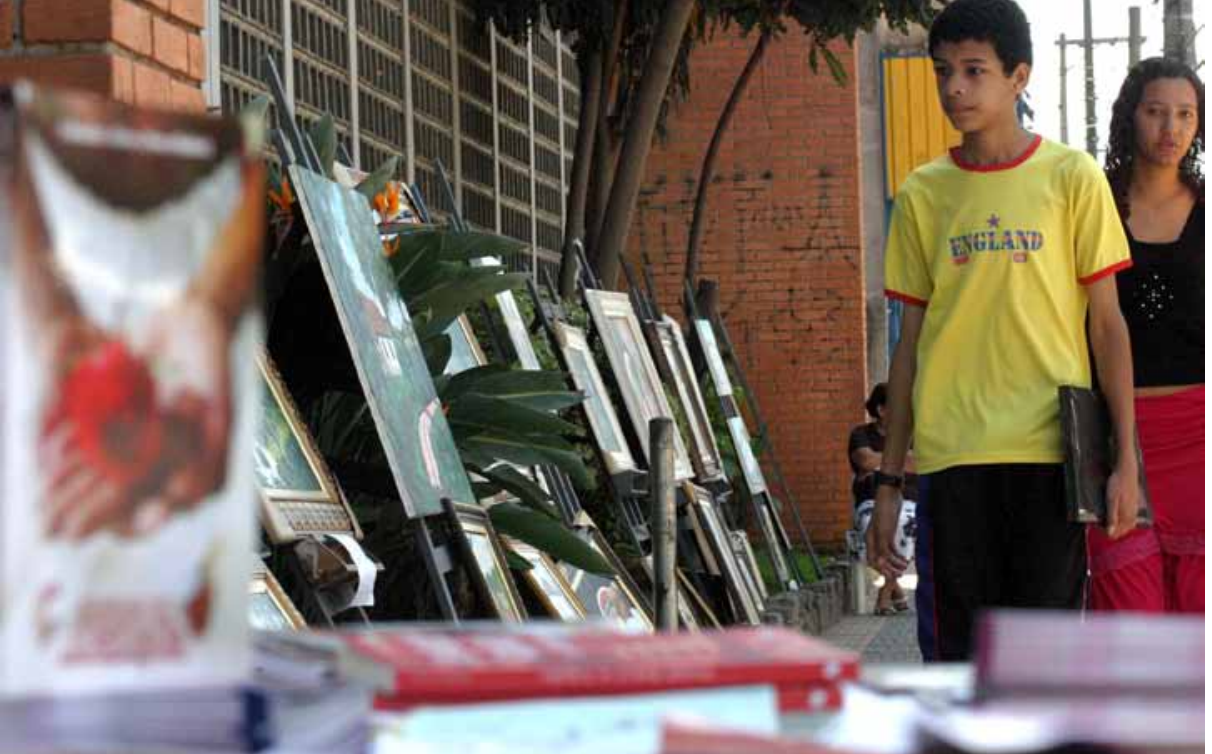

Suzano: Arte na Rua - Calçada do Centro Cultural Moriconi

Fonte: Wanderley Costa - Prefeitura Municipal de Suzano, 2007

Suzano: Capoeira - Praça Cidade das Flores

Fonte: Wanderley Costa - Prefeitura

Municipal de Suzano, 2009

Suzano: Roda de Todos os Santos -

Rua Tiradentes

Fonte: Wanderley Costa - Prefeitura

Municipal de Suzano, 2009 
7 BONILHA, I.. 0 desenho da paisagem à beira-rio e as metamorfoses da Várzea do Tietê na cidade de São Paulo. Dissertação (Mestrado) Faculdade de Arquitetura e Urbanismo, Universidade de São Paulo, São Paulo. 2002. p. 29.

8 SANTOS, M.. A natureza do espaço. São Paulo: Hucitec, 1996.
A partir dos exemplos citados, entende-se que a paisagem da cidade se constitui não somente em função dos recursos naturais disponíveis, mas também dos diversos processos pautados em práticas sociais e econômicas, sustentados a partir de ideologias e ações políticas distintas.

A paisagem urbana é, então, o resultado preciso das expressões econômicas, culturais e sociais dentro da conjuntura histórica e que se reflete em conflitos urbanísticos, apresentando-se claramente através da forma como as ocupações urbanas se consolidaram no espaço.

Sabemos que um dos resultados principais das ocupações urbanas são os assentamentos humanos que dão forma ao espaço. Estudá-los permite compreender de que maneira a paisagem se forma e sob quais interesses ela se dá.

As características do suporte físico como as áreas alagadas, as feições do relevo, interferem diretamente na forma como estes assentamentos humanos se constituem na paisagem, por serem capazes de direcionar o traçado das vias e ferrovias, o declive das ruas, os desniveis das edificações, além da configuração dos espaços livres, influenciando dessa maneira a forma urbana de um determinado território 7 .

Para além dos aspectos físicos, a paisagem urbana é uma estrutura que contém uma série de fatores indutores de comportamentos sociais nos seus espaços ${ }^{8}$, que podem ser acessiveis e de domínio de todos, através das manifestações artísticas de criatividade e espontaneidade que acontecem na esfera da vida pública.

Portanto, a paisagem se revela mediante sinais que refletem o estágio de evolução de uma determinada sociedade e pode ser 
flagrada pelos seus signos e símbolos, que representam os acordos feitos pelos meios de produção e a "negociação" com a natureza.

Ou seja, a paisagem expressa a inter-relação entre as dimensões naturais e econômicas, as quais apresentam equilibrios, interesses e tempos distintos, isso evidencia-se em alguns momentos:

- o equilibrio e os interesses distintos, surgem na medida em que ocorre ou há a possibilidade de esgotamento dos recursos naturais;

- $\quad$ o tempo distinto aparece no instante em que a exploração dos recursos se torna tão intensa que estes acabam não tendo a capacidade de se refazer no tempo necessário para que sua utilização volte a acontecer.

E para que a paisagem seja decifrada, com relação ao seu equilíbrio, interesses e tempos, há que se considerar os diversos sistemas que a formam: biofísico, cultural, social e econômico.

Assim, a análise pressupõe que os processos de transformação da paisagem do território aconteçam através das manifestações físicas naturais, como os que envolvem águas, matas e várzeas; físicas materiais, que ocorrem pelas ocupações; e sociais, como pelas políticas e pela economia.

No entanto, o que se observa no Brasil é que o interesse cotidiano da sociedade em geral não está voltado para a conservação dos bens naturais. Os padrões demonstram que seus desejos e necessidades se relacionam principalmente com os bens de valor econômico, os quais se remetem ao consumo imediato. 
${ }^{9}$ MACEDO, S. S.. Paisagem, urbanização e litoral do éden à cidade. Tese (Livre-Docência) - Faculdade de Arquitetura e Urbanismo, Universidade de São Paulo. São Paulo, 1993. p. 14.

10 Ibid., p. 12.

II MACEDO, S. S.. Paisagem, urbanização e litoral do éden à cidade. Tese (Livre-Docência) - Faculdade de Arquitetura e Urbanismo, Universidade de São Paulo. São Paulo, 1993.
Em função dos valores adotados pela maioria das pessoas que ocupam o território é que este passa a assumir constantes reordenamentos sociais, ecológicos, ambientais e culturais, organizando, dessa forma, outras realidades transformadoras da paisagem.

[...] A cada paisagem, a cada lugar, então, atribui-se três tipos de qualidade, que seriam:

1. Ambiental - que mede as possibilidades de vida e sobrevida de todos os seres vivos e de suas comunidades nele existente.

2. Funcional - que avalia o grau de eficiência do lugar no tocante ao funcionamento da sociedade humana.

3. Estética - valores com características puramente sociais, que cada comunidade em um momento de tempo atribui a algum lugar?.

Dessa maneira, o processo de formação da paisagem é compreendido a partir de todas as caracteristicas: funcionais do suporte físico, climáticas do lugar, dos ecossistemas existentes, dos valores sociais e culturais, dos padrões de ocupação antrópica, do grau de processamento das estruturas ambientais existentes, além dos elementos componentes da estrutura morfológica ${ }^{10}$.

A fim de que se possa desenvolver o levantamento das caracteristicas apontadas anteriormente, uma das formas de planejamento paisagístico a ser adotada trata-se dos procedimentos consolidados pela obra de lan Mac Harg em Design with nature, editada em 1967'I.

Ian Mac Harg foi o primeiro a realizar um estudo aprofundado sobre a interação entre os processos naturais e sociais na transformação da paisagem e a aplicar este conhecimento numa 
proposta metodológica para o planejamento e o projeto da paisagem (landscape design) ${ }^{12}$.

Seu método propõe a análise tanto das caracteristicas físicas, ou seja, naturais do território (geologia, hidrologia, edafologia, ecologia vegetal e fauna), quanto dos valores culturais considerados importantes para a população, como os lugares, as zonas e os edifícios de grande representatividade dentro de um território.

Com isto, busca-se valorizar a paisagem através de um processo de análise típica do planejamento paisagístico que prima pela articulação dos processos físicos e sociais, enaltecendo, sobretudo, a natureza, através de planos que estimulam a articulação dos espaços urbanos com os aspectos naturais, entendendo que ela guarda em si um conjunto de valores que implicam em oportunidades e benefícios para a sociedade.
12 BONILHA, I.. 0 desenho da paisagem à beira-rio e as metamorfoses da Várzea do Tietê na cidade de São Paulo. Dissertação (Mestrado) Faculdade de Arquitetura e Urbanismo, Universidade de São Paulo. São Paulo, 2002. p. 32. 


\section{Ecologia de paisagens}

Para Metzger (2006), a 'ecologia de paisagens' é uma área de conhecimento dentro da ecologia marcada pela existência de duas principais abordagens: uma geográfica, que privilegia o estudo da influência do homem sobre a paisagem e a gestão do território; e outra ecológica, que enfatiza a importância do contexto espacial sobre os processos ecológicos e a valorização destas relações em termos de conservação biológica.

Na sua interpretação, ela busca analisar as áreas heterogêneas, compreendendo os fluxos de seres vivos, bem como a alteração das estruturas com menos mobilidade conjuntamente com os processos ecológicos.

A ecologia de paisagens trabalha com a ideia de interligações, sendo que esta área do conhecimento tem como procedimento metodológico analisar temas como: matriz, mancha, fragmento, mosaico, conectividade, unidade de paisagem, elemento de paisagem, borda, entre outros.

0 estudo também compreende o padrão estrutural de uma paisagem, bem como sua funcionalidade, no que se refere ao fluxo dos animais, das águas, das matas, bem como dos homens, dentro desta estrutura e como tudo isto pode se articular dentro de um mosaico.

E como as articulações acontecem dentro de um mosaico, propõe-se que as soluções devam ser vistas em escala territorial, para que se trabalhe com grandes padrões, entendendo como fun- 
cionam para que se alcance um desenho que esteja em harmonia com a estrutura do sistema natural.

Dessa forma, aplicam-se os princípios da ecologia de paisagens tanto no planejamento, como no projeto paisagístico e manejo do território, para que o mosaico possa ser compreendido.

Os desafios constantes no planejamento da paisagem não se resumem a ter uma visão espacial e temporal ampla de uma área, ou seja, em compreender apenas a dimensão de um território e o momento em que as ações se consolidaram neste espaço, mas em entender as principais questões sociais e ambientais presentes que interferem na formação do mosaico.

Assim, por exemplo, algumas ações sociais derivam de processos econômicos, que não permitem que segmentos da população tenham condições de adquirir ou alugar moradias em áreas urbanizadas. Tal situação acaba sendo um dos fatores de criação de paisagens altamente processadas, como é o que acontece constantemente com as áreas de várzeas e as encostas frágeis, que são alteradas paulatinamente para 0 abrigo de comunidades.

Ou seja, a desvalorização de determinadas paisagens como as várzeas acabam acontecendo no instante em que as pessoas, por falta de recursos financeiros, se instalam em áreas protegidas por lei, causando a impermeabilização dos solos, além de sofrerem as consequências das inundações.

Por outro lado, quando um padrão alto de renda permite que parte da população tenha a oportunidade de conviver com recursos naturais, ou ainda quando ações públicas direcionam a ocupação de várzeas por parques lineares, isso permite que as pessoas con- 
13 BONILHA, I.. 0 desenho da paisagem à beira-rio e as metamorfoses da Várzea do Tietê na cidade de São Paulo. Dissertação (Mestrado) Faculdade de Arquitetura e Urbanismo, Universidade de São Paulo, São Paulo, 2002. p. 32. vivam de forma harmônica com as águas e as matas, valorizando as paisagens naturais.

Ou seja, de uma forma ou de outra o mosaico territorial passa a ser refém de constantes alterações, provenientes de ações sociais que transformam "ao longo do tempo, as funções da paisagem, correspondentes à dinâmica dos fluxos de energia e dos movimentos de matéria (sociedade, plantas e animais), as quais acabam resultando em novas estruturas e funções, configurando assim, processos de contínuos de paisagem" que variam de porte e extensão de acordo com o tempo e o lugar ${ }^{13}$.

Para tanto, o objetivo do planejamento ecológico da paisagem tem por função fornecer as ferramentas para alcançar uma integração entre sociedade e natureza, de forma que ambas prosperem a longo prazo, resultando na melhor paisagem para 0 desenvolvimento do território e, dessa forma, entende-se que a aplicação da ecologia de paisagem pode colaborar na superação dos conflitos existentes em determinados territórios.

Assim, os conceitos vinculados à ecologia de paisagens oferecem um conjunto de princípios que são capazes de serem aplicados ao projeto e ao planejamento das paisagens, dando a possibilidade de obtermos o controle das conexões e transformações, que acontecem sobre o território a partir da nossa atuação.

A ecologia de paisagens é uma importante ferramenta por propiciar variadas análises, interpretações e proposições que possibilitam a atuação dos planejadores da paisagem, tanto na escala da paisagem urbana territorial quanto na regional, a partir do entendimento das relações entre os diversos elementos do mosaico que compõe esta paisagem. 
Seus princípios aplicam-se a qualquer mosaico paisagístico, ou seja, contemplam áreas de intensa atividade urbana, agrícola, além dos desertos, florestas e áreas naturais, atuando em torno de três características principais:

- estrutura da paisagem, padrão espacial ou arranjo dos elementos paisagísticos que compõem o territóriol4;

- função, movimento e o fluxo de pessoas, animais, plantas, água, vento, matéria e energia, pela estrutura ${ }^{15}$;

- transformação e dinâmica ou alteração no padrão espacial e na função através do tempo ${ }^{16}$.

A estrutura da paisagem em cada região é composta por três tipos de elementos: manchas, corredores e matrizes, que são conceituados para desenvolver os princípios analíticos gerais da ecologia da paisagem. Seu entendimento também pode colaborar no planejamento do uso do solo, bem como para o padrão espacial que possui a capacidade de controlar fortemente os movimentos, fluxos e mudanças.

Para tanto, coloca-se a definição de alguns conceitos vinculados à ecologia de paisagens, para que em um momento posterior eles possam ser utilizados, objetivando-se o entendimento da paisagem do território de Suzano:

- $\quad$ unidade da paisagem - "é definida como um trecho que apresenta uma homogeneidade de configuração, caracterizada pela disposição e dimensão similares dos quatro elementos da paisagem: suporte físico, estrutura/padrão de drenagem, cobertura vegetal e mancha urbana" 17 ;

- $\quad$ matriz - é uma unidade de paisagem que controla a dinâmica ecológica de um determinado setor da paisagem, ou seja, ela é caracterizada pela máxima complexidade funcional e
14 PELLEGRINO, P. R. M.. Paisagens temáticas: Ambiente virtual. São Paulo: FAUUSP. Tese (Doutorado) Faculdade de Arquitetura e Urbanismo, Universidade de São Paulo. São Paulo, 1995. p. 31.

15 Ibid., p. 21.

16 Ibid., p. 39.

17 PROJETO ORLA: fundamentos para gestão integrada. Brasília: MMA/SQA; Brasília: MP/SPU, 2002. p. 38. 
18 METZGER, J. P.. o que é ecologia de paisagens?. Biota Neotropica v.1 (n.1) BN00701122001, 2001. p.8. www.biotaneotropica.org.br/v1n12/ pt/fullpaper?bn00701122001+pt. Acesso em: 14 de jan. 2012.
19 Ibid., p. 8.
20 Ibid., p. 7.
21 Ibid., p. 8.

ambiental, além de possuir grandes extensões lineares, sendo que, em geral, é reconhecida por recobrir a maior parte da paisagem, podendo ser natural (grandes fragmentos de mata) ou urbanizada (cidade). Para o entendimento da ecologia de paisagens, dentro de um dado recorte territorial, compreende-se a existência quanto à presença da matriz ou não, se ela é única ou subdividida, variada ou homogênea, contínua ou perfurada 18 ;

- manchas - são consideradas as áreas homogêneas de uma unidade da paisagem, possuindo extensões espaciais reduzidas e não-lineares ${ }^{19}$;

- corredores - são áreas homogêneas em uma determinada escala de uma unidade da paisagem, apresentando disposição espacial linear que ligam dois fragmentos, além disso, os corredores são avaliados no que se refere à sua largura e continuidade e também quanto ao fato de serem retos ou curvilineos ${ }^{20}$;

- fragmento - trata-se de uma mancha originada por fragmentação, ou seja, por subdivisão, promovida pelo homem, de uma unidade que inicialmente se apresentava sob forma contínua21;

- mosaico - é uma paisagem a qual apresenta determinada estrutura contendo mancha, corredor e matriz, ou pelo menos dois desses elementos, podendo os mosaicos serem compostos por áreas urbanizadas, agricultáveis, naturais ou de reflorestamento e etc.. Assim, os mosaicos paisagísticos, existentes sobre a superfície de qualquer território, são resultantes da combinação entre matrizes, corredores e manchas. Para a avaliação do mosaico considera-se de que maneira os elementos da paisagem estão colocados sobre um território, 
ou seja, analisa-se qual é a dimensão das manchas, seus formatos, recortes e agrupamentos 22 ;

- $\quad$ paisagem - trata-se de um mosaico heterogêneo formado por unidades interativas, podendo se apresentar com manchas, corredores e matrizes ${ }^{23}$;

- conectividade - é a capacidade que a paisagem, ou que as unidades da paisagem, possuem de facilitar os fluxos biológicos. Assim, o sucesso com relação à conectividade depende da proximidade dos elementos de habitat, da densidade dos corredores, quantidade de stepping stones, bem como da permeabilidade da matriz, seja ela natural ou urbanizada24;

- $\quad$ stepping stones - os "pontos de ligação" ou "trampolins ecológicos", são pequenas áreas de habitat como parques, manchas, maciços de vegetação, praças, etc., dispersas pela matriz que podem ser as áreas urbanizadas, os campos, bem como as áreas agricultáveis. Estes pontos de ligação são pequenos fragmentos utilizados para restabelecer a continuidade, quando outras formas são inviáveis ${ }^{25}$.

Dessa forma, ao possuir o entendimento dos conceitos expostos acima, é possivel promover rearranjos das formas de ocupação que compõem a paisagem, permitindo a implantação de políticas de uso e ocupação do solo, as quais possam trabalhar no intuito de reduzir a degradação dos fragmentos, assegurando a estabilidade dos ecossistemas que compõem o território.
22 Ibid., p. 8.

23 Ibid., p. 8.

24 Ibid., p. 7.

25 Ibid., p 8. 


\section{Dinâmica ambiental e urbanização: Introduzindo questões}

26 AFONSO, C. M.. A paisagem da Baixada Santista: Urbanização, transformação e conservação. São Paulo: Editora da Universidade de São Paulo; FAPESP, 2006. p. 27. Poluição do ar, contaminação das águas por lançamento de efluentes domésticos e/ou industriais, disposição de resíduos sólidos e resíduos da construção civil são problemas frequentes nas aglomerações urbanas, seja pelo Brasil ou no município de Suzano. Por consequência, configura-se um estado de crise ambiental crônica nos municípios da Região Metropolitana paulista, caracterizado pela grande supressão de áreas florestadas; pressão urbana sobre as áreas legalmente protegidas através da implantação de um padrão de assentamento que exige transformação total das características naturais, gerando, dessa forma, a poluição do ar, dos rios e das águas.

27 CHRISTOFOLETTI, A.. Modelagem de sistemas ambientais. São Paulo: Edgard Blucher, 1999. p 37.
Considerando que a paisagem também é resultado dos padrões de urbanização, a mancha urbana, bem como a estrutura sobre a qual ela acontece, é analisada paralelamente com a dinâmica ambiental, pois para além das transformações diretas que gera, "também provoca efeitos indiretos sobre os sistemas naturais" 26 .

Assim, o uso do adjetivo ambiental é direcionado para entender as características funcionais e dinâmicas dos sistemas que contemplam todos os seres vivos dentro dos contextos físicos, os quais envolvem os processos químicos e biológicos, abrangendo, dessa forma, os solos, as águas, o clima, a vegetação e também os contextos socioeconômicos que atuam sobre as atividades das comunidades humanas ${ }^{27}$.

Entende-se, ainda, que o termo 'ambiente' pode ser aplicado para diversas escalas de grandeza, ou seja: global, continental, regional e local, estendendo-se a espaços terrestres e aquáticos, oceânicos, lacustres, florestados e etc..

Dentro de uma escala específica compreende-se que todos os eventos que acontecem dentro de um espaço se expressam sobre uma organização espacial-territorial que abriga dessa maneira a produção de materiais e energia, que atuam diretamente nos sistemas socioeconômicos, produzindo edificações, insumos, emissões e resíduos que transformam o ambiente.

Por sua vez, esta organização espacial, que funciona pela interação dos fluxos de matéria e energia entre os seus compo- 
nentes, produz alterações em todas as suas áreas de abrangência. Assim, as mudanças ambientais implicam em transformações nas características e na qualidade ambiental dos espaços, relevantes para a sobrevivência dos ecossistemas.

Neste processo de transformação contínua dos ambientes, a sociedade humana é, com certeza, a responsável, nos últimos milênios, pela criação de diversos tipos de espaços e lugares, pela eliminação e proliferação de comunidades inteiras de seres vivos e, portanto, pela formalização de inúmeras paisagens ${ }^{28}$.

0 conceito de ecossistema pode ser compreendido como o conjunto de interações entre todos os seres vivos que habitam uma determinada área ou região relativamente homogênea de organismos que interagem com o seu ambiente, de modo que os fluxos de energia e de nutrientes, a produtividade, a dinâmica da população, a sucessão e a biodiversidade, possam promover a permuta de materiais entre os componentes vivos e abióticos 29 .

A sociedade expressa suas atividades por meio de diferentes padrões de ocupação, por ações que usufruem/exploram as potencialidades existentes no território, modificando-o e, consequentemente, alterando os aspectos do ambiente por vezes de maneira conflituosa.

Entende-se que quando as ocupações são feitas em concordância com o ambiente, ou seja, prevendo-se, por exemplo, a correta implantação das habitações, entre outros, em conformidade com: o uso e ocupação do solo, a legislação e o saneamento ambiental, não há motivos que impeçam a população de estar próxima a áreas de alto potencial ambiental, as quais são capazes de resguardar a qualidade de vida.
28 MACEDO, S. S.. Paisagem, urbanização e litoral do éden à cidade. Tese (Livre-Docência) - Faculdade de Arquitetura e Urbanismo, Universidade de São Paulo, São Paulo, 1993. p. 18.

29 Ibid., p. 35. 
Qualidade de vida esta que somente existe a partir do momento em que se garantam, ao cotidiano da população, oportunidades que possibilitem:

- usufruir de serviços ambientais voltado ao saneamento como o abastecimento de água que somente é possivel mediante a manutenção dos níveis adequados com relação aos recursos hídricos, bem como o equilíbrio ecológico aquático;

- conviver com o meio natural, na medida em que eles se apresentam através de ecossistemas com grande integridade no que se refere à dinâmica ambiental, possibilitando, dessa forma, que sejam desfrutados com relação a sua beleza cênica, além de oferecer oportunidades vinculadas ao lazer e à recreação;

- desfrutar do urbano, por ele criar oportunidades vinculadas ao ócio, através da implementação de praças e parques, bem como aos percursos agradáveis, na medida em que desenvolve calçadas com boa acessibilidade, que contemplem uma arborização capaz de trazer sombra e embelezamento.

Além disso, outros aspectos, como a preservação e a conservação das florestas, também estão vinculados à qualidade de vida, já que fornecem benefícios diretos e indiretos, através dos serviços ambientais e ecossistêmicos como os:

- reguladores, na medida em que as florestas realizam processos vitais que raramente recebem valor monetário, como a proteção dos rios, a regulação do clima e das chuvas e o armazenamento de carbono da atmosfera;

- de provisão, por fornecerem bens diretos, tais como os frutos, óleos, madeira, fibras, que resultam em alimento e matéria- 
-prima para produtos e indústrias, a exemplo da farmacêutica, de construção e de cosméticos;

- de suporte, ao propiciarem benefícios indiretos para as pessoas, como a formação dos solos e o crescimento das plantas, fundamentais aos outros serviços por promover o equilibrio dos ecossistemas;

- culturais, representados no turismo, nos esportes e no lazer, bens imateriais, ou seja, recreativos, estéticos, por resguardarem o embelezamento da paisagem e até espirituais, os quais são fornecidos pela floresta em função da ligação que o ser humano possui com ela.

Somando-se aos aspectos já colocados, entende-se ainda que para se ter qualidade de vida devem ser resguardados:

- a biodiversidade, pois ela garante tanto o fluxo de energia quanto as interações, entre todos os recursos naturais e seres vivos;

- $\quad$ ambiente urbano, na medida em que os cursos d'água e os fragmentos de mata nativa, inseridos nas áreas urbanizadas, são fundamentais para o meio ambiente da cidade, já que contribuem para a saúde das pessoas que vivem nestas áreas;

- $\quad$ extrativismo vegetal, no momento em que a exploração de recursos, tais como óleos, fitoterápicos, alimentos, fibras, dentre outros, são feitos com vistas ao não esgotamento dos mesmos, a fim de que estes possam continuar a ser utilizados;

- o desenvolvimento rural sustentável, considerando-se a necessidade de promover práticas vinculadas à agricultura, que não provoquem a degradação do solo, bem como das matas e dos recursos hídricos; 
30 Compreende-se como 'impacto ambiental' qualquer deterioração do meio ambiente que decorre de atividade humana. A Resolução n. 1/86 do CONAMA, em seu Art. $1^{\circ}$, considera impacto ambiental "qualquer alteração das propriedades físicas, químicas e biológicas do meio ambiente, causada por qualquer forma de matéria ou energia resultante das atividades humanas que direta ou indiretamente afetam: I - a saúde, a segurança e o bem-estar da população; II - as atividades sociais e econômicas; III a biota; IV - as condições estéticas e sanitárias do meio ambiente; $\mathrm{V}$ - a qualidade dos recursos ambientais".

\section{${ }^{31}$ AFONSO, C. M.. A paisagem da}

Baixada Santista: Urbanização, transformação e conservação. São Paulo: Editora da Universidade de São Paulo; FAPESP, 2006. p. 37.
- a cidadania, com o intuito de estimular atividades vinculadas a uma sociedade educadora e ambientalista;

- 0 desenvolvimento socioeconômico em conformidade com a conservação e a preservação dos recursos ambientais, considerando-se a necessidade quanto à conservação da atmosfera, das águas interiores, superficiais e subterrâneas, dos estuários, do mar territorial, do solo e subsolo, além dos elementos da biosfera.

Assim, continuamente a sociedade pode promover situações que atuam no bem-estar do território, através de ações geradas pela urbanização.

A intensidade destas ações humanas, que modificam o meio ambiente, pode ser definida como impactos ambientais, os quais possuem sua origem, por diversas vezes pautadas nas atividades socioeconômicas, tais como as ações imobiliárias, comerciais e industriais 30 .

Os impactos são, portanto, efeitos e transformações impressos sobre o ambiente, provocados pelas ações humanas no meio ambiente físico que refletem, por interação, nas condições que envolvem a vida e as atividades humanas 31 .

Assim, estas mudanças sensiveis, ora positivas, ora negativas, acidentais ou planejadas, diretas ou indiretas, interferem nas condições da qualidade de vida das pessoas, bem como na estabilidade dos ecossistemas.

Nesse sentido, a urbanização é considerada como um processo que possui alta capacidade de transformar o ambiente pelas ações diretas ou indiretas da sociedade humana, que atua sobre as 
águas, terras e atmosferas, produzindo as mais diversas formas de alteração.

Ou seja, a dinâmica das relações sociais interfere diretamente na organização espacial das cidades e na sobrevivência dos recursos locais, sejam eles paisagísticos ou ambientais, definindo padrões específicos de urbanização.

Essa dinâmica, por sua vez ora resulta em acertos por respeitar as dinâmicas ecológicas e ambientais de um território, porém em outros momentos resulta em desacertos em função de suas ações provocarem a degradação da qualidade ambiental explícita dos solos, das águas e das matas.

Oficialmente, no Brasil, os desacertos se efetivam no momento em que: a população ocupa áreas de várzeas que deveriam ser preservadas, os fragmentos florestais são retirados a fim de atenderem às demandas das ocupações urbanas e agrícolas, os corpos d'água são contaminados por efluentes líquidos das empresas, além do instante em que ocorre o descarte irregular de resíduos da construção civil em terrenos não ocupados.

Segundo a Lei n. 6.938/81, que dispõe sobre a Política Nacional de Meio Ambiente, em seu Art. $3^{\circ}$, é colocado que "entende-se por degradação da qualidade ambiental, a alteração adversa das características do meio ambiente".

Desse modo um território oferece possibilidades múltiplas de interações, sendo assim a forma como acontece a urbanização favorece ou não estas relações. Ela pode fomentar grandes encontros como a possibilidade das comunidades conviverem com a natureza, ou pode ocorrer de tal forma que a população tenha um 
contato esporádico com as áreas não urbanizadas, perdendo-se a relação íntima com a mesma.

Por outro lado, no cotidiano urbano, esta convivência não é estritamente necessária. Uma cidade que possui: moradores com uma renda suficiente para as necessidades básicas, arrecadação expressiva, boas condições urbanísticas (ruas, avenidas, calçadas, canteiros centrais, praças, parques e etc.), uma administração pública que se preocupa com as demandas sociais e urbanísticas, possibilita ao morador uma vida de alta qualidade.

Mas, além das ações da sociedade, outros fatores também interferem na formalização de novas paisagens, como os próprios fenômenos naturais, que se expressam pelas mudanças do clima, deslocamentos da terra, os quais geram terremotos, bem como os processos vulcânicos.

0 que se constata é que as transformações somente sensibilizam as comunidades no instante em que estas são afetadas em seu cotidiano, com efeitos imediatos e agressivos, que trazem grandes transtornos à saúde, à economia, e até mesmo à própria vida da população em momentos de crise extrema, causada muitas vezes por grandes inundações, desmoronamentos de terra, contaminações químicas e ausência de água potável.

Situações estas que provocam alteração no valor do solo, deslocamentos da população para outros espaços, o que acaba por gerar interferências não somente no local em questão, mas também nos lugares de influência da área diretamente afetada.

Verifica-se, assim, que em "bons momentos", quando não se têm alterações vinculadas ao meio ambiente que reflitam diretamente no cotidiano das pessoas, garantindo-se consequentemente 
o abastecimento de água, a produção de alimentos, a saúde, a circulação viária e de pedestres, bem como o equilíbrio da economia, os efeitos negativos não são percebidos ou considerados.

No entanto, observa-se que em determinados momentos, espaços que deveriam ser preservados, sofrem com diversos niveis de processamento. Na Grande São Paulo, por exemplo, em função do seu adensamento, tecnologias sofisticadas foram utilizadas para a apropriação dos vales dos rios já existentes, produzindo drásticas transformações no contexto local e gerando uma urbanização altamente conflituosa, densa, com o solo intensamente impermeabilizado e com sua drenagem em grande parte encoberta, sendo comuns as altas temperaturas e enchentes.

Ou seja, esse exemplo passa a ser um modelo, o qual é continuamente imposto às grandes metrópoles. Dessa forma, seus assentamentos e sobrevida exigem naturalmente altos investimentos e drásticas transformações no suporte físico, envolvendo complexas técnicas de engenharia para a sua efetivação ${ }^{32}$.

Portanto, observa-se que determinadas formas de ocupação comprometem o meio ambiente devido aos agressivos processos de transformação da estrutura ambiental. No entanto, existem alternativas para possibilitar que os assentamentos ocorram sem que os ecossistemas sejam segregados ou extirpados, a partir de formas de urbanização que valorizem a convivência equilibrada entre as comunidades e as estruturas ambientais.

Ao remetermos estes diálogos para o Brasil, observamos que "muito se avançou, no tocante à discussão da questão ambiental, como um todo, na segunda metade do século XX"33. A partir dos primeiros anos do século passado, diversas medidas sanitaristas
32 MACEDO, S. S.. Paisagem, urbanização e litoral do éden à cidade. Tese (Livre-Docência) - Faculdade de Arquitetura e Urbanismo, Universidade de São Paulo, São Paulo, 1993. p. 18.

33 Ibid., p. 19. 
34 Idem.

35 Com isso, os benefícios ambientais e paisagísticos vão sendo eliminados a partir de práticas consolidadas como a eliminação e impermeabilização das várzeas e das encostas, a exemplo do que ocorre em boa parte da Região Metropolitana de São Paulo, onde seus espaços são destinados para a circulação de veículos, bem como para as instalações urbanas. foram tomadas no Rio de Janeiro, principalmente em função das grandes epidemias ali observadas, causadas, especialmente, em decorrência da insalubridade da cidade, permitindo que as outras se modernizassem, através da inserção de diversos melhoramentos urbanos e pela formulação de uma série de medidas priorizando a qualidade ambiental, tendo em vista, a questão da saúde pública ${ }^{34}$.

No entanto, verifica-se que apesar dos avanços, o objetivo na prática estava voltado para a expansão das cidades, que se faz sobre todo e qualquer espaço disponivel, desprezando-se em geral qualquer cuidado ambiental, o que acabou por gerar diversos tipos de poluição como a contaminação das águas, do ar, das represas, além das erosões e assoreamentos 35 .

Segundo a Lei n. 6.938/81, a qual dispõe sobre a Política Nacional de Meio Ambiente, em seu Art. $3^{\circ}$, é colocado que "entende-se por poluição, a degradação da qualidade ambiental, resultante de atividades que direta ou indiretamente: prejudicam a saúde, a segurança e o bem-estar da população, atuem na criação de condições adversas às atividades sociais e econômicas, afetem desfavoravelmente a biota e as condições estéticas ou sanitárias do meio ambiente e lancem matérias ou energia em desacordo com padrões ambientais estabelecidos".

As agendas ambientais contemporâneas mostram que a solução para esta crise, entre o urbano e o ambiente, passa pela busca do equilíbrio entre as dinâmicas urbana e natural, superando-se os conflitos e as angústias constantes, entendendo-se em um primeiro momento que: ou se urbaniza ou se conserva, o que não é possivel, claro, pois as cidades, assim como a natureza, necessitam existir. 
E na busca por esse constante equilíbrio, que nunca chegará ao ideal, alguns fatores se apresentam como primordiais para que ao menos uma tentativa aconteça.

Fatores estes que se pautam no tratamento dos efluentes urbanos, no uso de tecnologias 'limpas' nos processos industriais, além da substituição nas novas frentes de expansão urbana, do padrão de assentamento hoje, em 2012, predominante, por um modo alternativo de urbanizar que se fundamente nas condições e nos processos naturais locais e regionais, tornando-se assim fundamentais para que o equilíbrio seja minimamente alcançado ${ }^{36}$.
36 AFONSO, C. M.. A paisagem da Baixada Santista: urbanização, transformação e conservação. São Paulo: Editora da Universidade de São Paulo, 2006. p. 27. 


\section{A produção do espaço e os processos de urbanização e degradação: Características gerais}

A produção do espaço é pautada nos aspectos sociais, físicos e ambientais, já que eles atuam junto ao cotidiano da população, dando a ela a possibilidade de incorporar à sua vida hierarquias sociais, decisões, distâncias, alternativas de lazer, cultura e situações, ou seja, bens imateriais que devem ou deveriam resguardar a qualidade da vida sobre o território.

Assim, apesar do crescimento, que se pauta em critérios unicamente exatos, ou seja, vinculado apenas a aspectos econômicos, ser um fator fundamental ao desenvolvimento, entende-se que as transformações junto a um território devem ser qualitativas e não apenas quantitativas.

Dessa forma, estabelecer um quadro conceitual que permita compreender a produção do espaço urbano torna-se fundamental para o entendimento da cidade contemporânea (2012), a qual se organiza e reorganiza tendo como base as mudanças constantes provenientes da economia e do social.

Economia esta que se apresenta de maneira diferenciada, por possuir investimentos múltiplos nos mais diversos setores e niveis de gestão, sejam eles públicos ou privados. Os públicos estão atrelados às economias voltadas para a educação, saúde, habitação, meio ambiente, desenvolvimento econômico, agricultura, transporte, entre outros, enquanto a economia privada volta-se ao setor de produção de papel e celulose, químico, de medicamentos, bens de consumo duráveis como a produção de peças, de higiene pessoal, etc.. 
Por consequência, estes investimentos acontecem nas diferentes porções do território, em cada espaço e tempo, em função: das suas características físicas que por muitas vezes estão interligadas aos recursos naturais; das questões sociais, que podem estar em determinados momentos ligados aos movimentos de moradia; das ideologias e politicas existentes sobre a cidade, as quais representam interesses coletivos e individuais.

Assim, cada território é um elemento sobre o qual o capital atua e se fixa, produzindo ingredientes essenciais para que a sociedade possa se desenvolver, através das instalações produtivas, do beneficiamento dos recursos naturais, bem como da implementação de infraestrutura física necessária à fixação do comércio, da indústria e das comunicações ${ }^{37}$.

Ou seja, todos estes movimentos que se dão em torno da economia e do social possuem a capacidade de intervir sobre 0 município através dos processos de trabalho privado, práticas do poder público e também por hábitos de consumo gerados pela sociedade.

Dessa forma, a cidade brasileira contemporânea média e grande, que se encontra sob a égide de estruturas políticas dotadas de amplas e complexas capacidades organizacionais que possuem habilidades para controlar a produção deste espaço, se altera constantemente mediante aos reflexos da economia, os quais podem ser compreendidos em função dos ciclos sistêmicos ${ }^{38}$.

A cidade contemporânea brasileira, por sua vez, é natural e formalmente híbrida, por guardar: muitas formas de apropriação do espaço produzidas em épocas diversas que se expressam através das várias densidades populacionais, tipos de ocupações dos
37 HARVEY, D.. Condição pós-moderna: Uma pesquisa sobre as origens da mudança cultural. São Paulo: Loyola, 1993.

38 Os ciclos são fenômenos capitalistas que expressam uma série de transições e rupturas, vinculadas à existência do Capital e são representados por quatro momentos bastante discerníveis pelos ciclos genovês, holandês, britânico e o atual, norteamericano. Cada ciclo demonstra o encerramento de determinados períodos financeiros dentro de um cenário, podendo ser tomados como exemplos interligados de um único processo histórico de expansão capitalista e que possuem a capacidade de reestruturar a economia mundial atuando consequentemente na produção do espaço (ARRIGHI, 1996). 
39 YÁZIGI, E.. Turismo e paisagem.

São Paulo: Contexto, 2002. lotes, densidades construídas, tempos de ociosidade da sociedade, condições climáticas, ecossistemas existentes, hábitos sociais e tensões diversas, que são materializados sobre o território 39 .

Esta diversidade impressa sobre o espaço por inúmeras vezes acaba por gerar conflitos junto aos recursos naturais e às áreas urbanizadas, expressando-se através das desigualdades, que acabam em um país como o Brasil e em muitos outros locais por excluir parte significativa da população ao acesso à terra urbana, à moradia, obrigando-a, de um modo informal, a ocupar espaços públicos e privados de interesse paisagístico e ambiental, bem como áreas de conservação e preservação ambiental, além de parques e reservas.

Assim, verifica-se que a paisagem e o ambiente se constituem a partir de premissas que visam resguardar o controle do território, no sentido de garantir a posse e o acesso aos bens de produção, bem como dos recursos humanos e naturais, em função da constituição e do desenvolvimento do poder econômico, 0 que acaba por excluir necessidades de uma sociedade, que devem ser baseadas também nos aspectos sociais, ambientais, ecológicos, culturais e históricos.

Entende-se, ainda, que a produção em escala mundial, através do sistema econômico, incentiva a ocupação e o uso de vastos territórios, o que leva a uma escassez prévia dos recursos em pontos diversos, imposta pela produção capitalista que estimula a constante criação de novas fronteiras com o consumo e, como em quase todas as formas de produção moderna, sem a equidade social e o equilíbrio ambiental. 
POTENCIALIDADES E CONFLITOS: UMA APROXIMAÇÃO CONCEITUAL E PRÁTICA

Portanto, compreende-se que o ambiente, compreendido em sua complexidade, é tomado não somente como meio natural, mas sim como o resultado dinâmico das inter-relações entre os processos sociais e os fenômenos do suporte biofísico. 


\section{Crescimento e desenvolvimento sustentável}

40 VEIGA, J. E.. Desenvolvimento sustentável. $O$ desafio do século XXI. Rio de Janeiro: Garamond Universitária, 2005.

$4 \mathrm{I}$ Para os fins previstos na Lei $\mathrm{n}$. 6.938/8, em seu Art. $3^{\circ}$, inciso II, entende-se por "degradação da qualidade ambiental a alteração adversa das características do meio ambiente".
No intuito de se obter o entendimento dos conflitos urbanos contemporâneos neste momento, colocam-se os dois conceitos acima, procurando, em especial, associar a questão ambiental aos recursos naturais finitos. Dessa forma, são analisados os conceitos voltados ao crescimento econômico e desenvolvimento sustentável, com o objetivo de compreendermos suas diferenças, sobreposições e inter-relações.

A possibilidade de crescimento indefinido, resultante das forças de mercado, passa a ser insuportável mediante à finitude dos recursos naturais existentes no território ${ }^{40}$. Esta é uma percepção contemporânea colocada na segunda metade do século $X X$, a qual surge a partir deste momento como uma nova modalidade de planejamento, evidenciando que as intervenções humanas ocorram dentro da capacidade de suporte dos ecossistemas.

0 crescimento, entendido de um modo tradicional, é expresso somente como uma expansão contínua das atividades econômicas, sociais e urbanas, na medida em que possibilita a sociedade desfrutar de seus produtos, não se preocupando com a manutenção dos recursos naturais. Ou seja, eles são utilizados, sem que haja a preocupação com relação a sua capacidade de se refazer. Ele é capaz de deflagrar processos de degradação da qualidade ambiental junto aos ciclos essenciais à vida, como os da água, terra, vegetação e ar de forma irrecuperável ${ }^{4}$.

Um exemplo é a forma como parte da indústria usufrui dos recursos hídricos, pois elas se utilizam dele para a sua produção e, 
em contrapartida, devolvem seus efluentes sem tratamento algum para os corpos d' água.

Ou seja, o crescimento acontece através de uma realidade que é objetiva, pautada no mercado do capital, já que a produção dos bens de consumo se coloca de maneira imprescindivel para o cotidiano das pessoas. 0 mercado, por sua vez, em função de se apropriar da natureza como meio de produção e fonte de riqueza, simplifica em função da sua lógica e da sua razão, a complexidade dos processos naturais, destruindo as identidades culturais, paisagísticas e éticas, ou seja, ele reduz os potenciais da natureza como simples capitais de mercado, a serem utilizados para a produção dos bens de consumo ${ }^{42}$.

Por isso, observa-se a existência de fortes contradições entre os processos ecológicos e os processos produtivos, os quais se dão em função de existir os diferentes: valores nas esferas institucionais, modelos de conhecimento, classes, grupos e atores sociais, os quais possuem desejos incompativeis ${ }^{43}$.

Nesse sentido, um território acaba expressando o efeito de um conjunto de práticas sociais, econômicas e culturais, que se articulam e se organizam através de regras, meios e fins construídos de acordo com os interesses específicos dos grupos e indivíduos que atuam sobre ele.

Estas práticas, por sua vez, geram contradições e relações entre a lógica e a dinâmica econômica, junto aos processos ecológicos ${ }^{44}$.

Por desconhecer ou ignorar as leis de conservação, essa dinâmica atua diretamente na degradação do espaço, já que suas ações
42 LEFF, H, Saber Ambiental: Sustentabilidade, racionalidade, complexidade e poder. Petrópolis, RJ: Vozes, 2001.

43 Ibid., p. 134.

44 Ibid., p. 134. 
45 Ibid., p. 23. comumente transcendem todas as normas, com o objetivo único de controlar o espaço a fim de obter avanços econômicos ${ }^{45}$.

Quanto ao desenvolvimento sustentável, ele é pautado na qualidade de vida que requer distribuição de renda justa, acesso pleno à saúde, educação, cultura, acessibilidade, bem como ao meio ambiente. Ele deve ser entendido como um processo socioeconômico que se constitui a partir de bases que levam em consideração a melhoria dos padrões econômicos e socioambientais, garantindo às gerações futuras, ou ao menos parte delas, a capacidade de produzir.

Além disso, o conceito possui como premissa a sustentabilidade, o que significa que a ele devem ser incorporadas dimensões sociais, culturais, ecológicas, ambientais e territoriais, ou seja, é necessário tratá-lo além do embasamento essencialmente econômico, puro e analítico.

Sob a perspectiva ecológica, a sustentabilidade é permeada por três princípios fundamentais: a conservação das dinâmicas ecológicas que sustentam a vida e a biodiversidade, a garantia da sustentabilidade dos usos que utilizam recursos renováveis e a permanência das ações humanas dentro da capacidade de suporte dos ecossistemas.

Assim ela possui como princípios a evolução socialmente includente, economicamente equilibrada, culturalmente diversa, além de estimular novos padrões de produção e consumo, ou seja, contribui na inserção de referenciais que busquem a sustentabilidade socioambiental.

Este modelo propõe a substituição do crescimento usual e socialmente perverso, que se alimenta de desigualdades crescentes, 
pautados simplesmente na economia de mercado, por padrões que contemplem e valorizem o ambiente e o ser humano.

Valorização esta, a qual tem como premissa o desenvolvimento econômico pautado em objetivos que levem em consideração não somente a produção dos bens de consumo, utilizando-se dos recursos naturais de maneira a não degradá-los. Ter que garantir uma renda mínima para o ser humano não é o suficiente, pois o importante é garantir a renda necessária para que a população tenha qualidade de vida.

A partir desta compreensão é que o conceito de desenvolvimento sustentável, que une os dois conceitos analisados anteriormente (desenvolvimento e sustentabilidade), surge como uma estratégia mundial para a conservação, lançado pela União Mundial para a Conservação (IUCN) e pelo Fundo Mundial para a Conservação (WWF), apoiados pelo Programa das Nações Unidas para o Meio Ambiente (PNUMA).

Ele é definido como um processo que permite satisfazer necessidades da população atual sem comprometer a capacidade de atender as gerações futuras. Para tanto, entende-se a importância de serem implementadas estratégias políticas que trabalhem para que seja resguardada a sobrevivência do gênero humano, a partir do esforço compartilhado de toda a sociedade ${ }^{46}$.

"O conceito se coloca contrário a ideia de um crescimento sustentado, sem uma justificativa rigorosa da capacidade do sistema econômico de internalizar as condições ecológicas e sociais (de sustentabilidade, equidade, justiça e democracia) deste processo. $47^{\prime \prime}$
46 LEFF, H.. Saber Ambiental: Sustentabilidade, racionalidade, complexidade e poder. Petrópolis, RJ: Vozes, 2001. p. 19.

47 Ibid., p.19. 
48 Ibid., p. 28.

49 Ibid., p.133.

50 Ibid., p.133.

$5 I$ Ibid., p.134.

52 Ibid., p.134.

0 discurso voltado ao desenvolvimento sustentável visa superar: os conflitos como a pobreza extrema, a não satisfação das necessidades básicas, a deterioração das condições de vida, as ações impostas pelo processo de transição para a modernidade, buscando, dessa maneira, estabelecer novas formas de convivência e apropriação da natureza ${ }^{48}$. Além disso, ele questiona os custos socioambientais derivados de uma razão puramente pautada no cálculo econômico, bem como a eficácia dos sistemas tecnológicos com relação à exploração dos recursos naturais ${ }^{49}$.

Assim, para superar esta racionalidade produtiva sugere-se a introdução de reformas democráticas no Estado, a incorporação de normas ecológicas junto aos setores público e privado, a criação de novas técnicas de produção, bem como a dissolução das externalidades socioambientais geradas pela lógica do capital ${ }^{50}$. Com isto, são propostas outras formas de desenvolvimento a partir de novos princípios éticos que respeitem os potenciais ecológicos, da transformação dos processos econômicos, da implementação de políticas tecnológicas e educativas alternativas ${ }^{51}$.

Dessa maneira o discurso ambientalista, mesmo em suas formas menos radicais, sugere a reorientação da ordem econômica dominante mediante a incorporação de novos instrumentos econômicos que mobilizem um conjunto de mudanças sociais e transformações institucionais para internalizar as bases ecológicas e sociais de um desenvolvimento sustentável${ }^{52}$.

Assim, a resolução da questão ambiental, bem como a construção de novas formas de transformar o ambiente, que oriente a transição para um desenvolvimento sustentável, requer a mobilização de um conjunto de processos sociais como, a formação de uma consciência ecológica, o planejamento matricial da adminis- 
tração pública, a participação da sociedade na gestão dos recursos ambientais, a reorganização interdisciplinar do saber, bem como a ampliação de conhecimentos ${ }^{53}$.

Mas para que isso aconteça, um conjunto de significações, normas, valores, interesses e ações socioculturais, além da busca do bem comum com a intervenção do Estado e a participação da sociedade civil num processo de reapropriação da natureza, devem ser trabalhados a fim de orientar seus valores e potenciais para um desenvolvimento sustentável e democrático ${ }^{54}$.

A estratégia proposta prevê uma harmonização entre 0 desenvolvimento socioeconômico através da conservação do meio ambiente, com ênfase na preservação dos ecossistemas naturais e na diversidade genética para a utilização racional dos recursos naturais.

0 princípio do desenvolvimento sustentável pressupõe a utilização dos recursos naturais pelo homem na linha de mínimo risco, isto é, sem a degradação do meio e da depredação das fontes de alimento e energia. Este desenvolvimento seria controlado a fim de garantir recursos para o futuro através da atuação do poder público na moderação de conflitos, incentivo das regulamentações ambientais, implementação de subsídios voltados à conservação da natureza, efetivação da fiscalização, articulação social e incremento de infraestrutura voltada ao saneamento ambiental.

Entende-se, assim, que a dimensão econômica não pode ser imposta e entendida como a única estratégia capaz de resguardar as necessidades humanas, considerando-se que os recursos naturais, tal como o sistema hídrico, são fundamentais à sobrevivência.
53 Ibid., p.135.

54 Ibid., p.143. 
55 MACEDO, S.S. \& QUEIROGA, E. F.. Os sistemas de espaços livres e a constituição da esfera pública contemporânea no Brasil. São Paulo: FAUUSP, 2011. p. 28.
Para além das questões que foram colocadas anteriormente abordando o desenvolvimento e o crescimento, ao refletirmos sobre o desenvolvimento sustentável, entendemos que ele perpassa de maneira intrínseca sobre a temática voltada ao sistema de espaços livres públicos, objeto desta dissertação.

[...] "No Relatório Brundtland consta como o "[...] desenvolvimento que satisfaz as necessidades do presente, sem comprometer a capacidade das gerações futuras satisfazerem as suas próprias necessidades." Destarte, a noção é constituida por outras abstrações: "desenvolvimento", "satisfação de necessidades", "necessidades do presente", "capacidade das gerações", "gerações futuras" e "próprias necessidades". 55

Assim, diversos temas como os desafios socioambientais, a legislação que se cumpre ou não em um território, o crescimento populacional, a utilização de água e energia, a longo prazo, a preservação da biodiversidade e dos ecossistemas, o controle da urbanização e 0 atendimento das necessidades básicas voltadas à saúde e à moradia, interferem no desenvolvimento sustentável de um território, e consequentemente na consolidação de espaços considerados ambientalmente corretos, como os corredores ecológicos e alguns parques lineares.

Dessa forma, tem-se que, constantemente, as formas de ocupação por muitas vezes se colocam contrárias às premissas voltadas ao desenvolvimento sustentável e, no entanto, o que se constata é que a aplicação deste somente iria contribuir para a gestão do território e, consequentemente, dos espaços livres.

Para que o conceito possa ser aplicado, deve haver um pacto social direcionado e equilibrado entre os agentes econômicos, po- 
líticos, sociais, culturais e ambientais, podendo ter como resultado um processo social:

- gerador de excedentes e técnicas confiáveis de produção, preservador das condições naturais;

- $\quad$ objetivador de soluções;

- político com ampla participação no cotidiano da população;

- $\quad$ voltado à renda da população;

- disposto a superar as deficiências existentes no saneamento ambiental;

- $\quad$ inovador com relação a políticas, por um exemplo, voltadas à educação e à saúde.

No entanto, embora se entenda a importância da sustentabilidade, sabemos que no aspecto prático este conceito é incoerente, pois alcançar o desenvolvimento econômico, sob bases sociais justas e sem danificar o meio ambiente, ainda que seja na linha de mínimo risco, trata-se de uma prática utópica (em 2012). As próprias ações cotidianas como as formas de ocupações, o modelo de crescimento econômico imposto, os tímidos investimentos por parte do poder público e privado na conservação dos recursos naturais, demonstram claramente como o conceito de desenvolvimento sustentável é ignorado totalmente ou parcialmente.

Isto porque toda sociedade é configurada por grupos e interesses diversos, que possuem a capacidade de atuar na produção do espaço de maneira diversificada, promovendo processos que se apresentam de forma contraditória à preservação, conservação e restauração do meio ambiente.

Verifica-se que comerciantes, empresários, entidades de classe como as associações de arquitetos e advogados, as associações 
vinculadas aos movimentos de moradia, as ONG's ambientalistas, os grupos partidários sejam da situação ou oposição, os grupos voltados à religião, todos interferem no desenvolvimento do território, sendo que por vezes essa atuação pode ser favorável ou não à sua paisagem, bem como ao seu ambiente.

Fica claro que o crescimento urbano exige espaço, no entanto, este espaço nem sempre consegue resguardar: as qualidades ambientais e paisagísticas, além do acesso à educação e saúde, bem como os espaços livres, para que ele aconteça de maneira a atender a demanda da população.

No entanto, cabe ao Poder Público criar e aplicar políticas públicas já existentes na forma de legislação, para que este crescimento não se dê de forma a prejudicar espaços que já tiveram muitas perdas, mas que ainda possuam um quadro relativo de estabilidade ambiental e paisagística. 


\section{Sistema de espaços livres públicos como elementos da paisagem urbana: Conceitos}

Compreende-se como 'Sistema' todo o conjunto de espaços livres que se insere dentro de uma paisagem urbana de forma articulada e com capacidade de exprimir multiplicidade, totalidade, diversidade, organização e complexidade, sendo que qualquer ação impressa sobre esta paisagem, certamente, vai gerar uma reação correspondente, no caso equivalente ao surgimento de uma alteração morfológica parcial ou total ${ }^{56}$. Um sistema cumpre múltiplos papéis, que por vezes estão sobrepostos à circulação, à drenagem urbana, a atividades do ócio, imaginário e memória urbana, ao conforto ambiental, à conservação e requalificação ambiental, além do convívio.

"Não há tipo único ou ideal de sistema, pois cada cidade possui características específicas de tecido urbano em função de sua formação histórica, características socioeconômicas, do seu lugar geográfico e do seu suporte físico." 57

Assim, compreendemos que o espaço livre é tudo aquilo que está fora do edifício, por isso entende-se que os recursos naturais e os artificiais são espaços livres de um território, podendo compor um subsistema do sistema.

Os recursos naturais podem ser representados por fragmentos de mata inseridos em parques, reservas, áreas de mananciais, entre outros, sendo a água o principal elemento comum capaz de promover as interligações, considerando-se que junto aos corpos hídricos podemos ter corredores ecológicos e parques lineares capazes de fazer as conexões.
56 MACEDO, S.S.. Quadro do paisagismo no Brasil. São Paulo: FAUUSP, 1999.

57 MACEDO, S.S. \& QUEIROGA, E. F.. Os sistemas de espaços livres e a constituição da esfera pública contemporânea no Brasil. São Paulo: FAUUSP, 2011, p. 18. 
Recursos artificiais são expressos pelo sistema viário, que também cumpre um papel fundamental na interligação e articulação dos outros tipos de espaços públicos como praças, parques entre outros, contribuindo, dessa maneira, para a constituição do sistema.

"Entende-se como conceito de sistema de espaços livres (SEL) urbanos os elementos espaciais e as relações que organizam e estruturam o conjunto de todos os espaços livres de determinado recorte urbano - da escala intraurbana à regional." 58

Por sua vez, toda cidade tem um sistema de espaços livres que é produzido tanto pelo Poder Público como pela iniciativa privada, ou seja, composto por espaços privados e públicos.

Os espaços livres privados nem sempre se articulam com os espaços livres públicos, se configurando na forma de jardins das casas, pesqueiros, áreas de lazer dos condomínios residenciais, estacionamentos, áreas externas a restaurantes e bares, além de grandes glebas não parceladas, etc..

Espaço público é toda propriedade pública de uso comum do povo dentro de uma paisagem, como as ruas, praças, parques e imóveis do Poder Público, além de todos os lugares de apropriação pública onde se realizam ações da esfera pública.

Quanto aos espaços livres públicos urbanos, eles existem independentemente de sua dimensão, qualificação estética funcional e de sua localização e característica, podendo ser configurados por calçadas, vias, praças, parques, etc..

0 que se compreende é que os espaços livres públicos "podem servir tanto para as organizações de usos e fluxos como podem 
ser simples ajardinamentos. Há aqueles que melhoram a condição de vida da comunidade; aqueles que mudam a maneira como os lugares são percebidos e que podem, por isto, levar a outras transformações; e há aqueles produzidos com fins unicamente eleitoreiros, que não se sustentam a longo prazo."59

Existem, ainda, os espaços livres públicos urbanos que são elaborados e dinamizados para atrair novos usos. Dessa forma, pequenos largos, praças, parques públicos, calçadas e passagens e viadutos qualificados, contribuem com a qualidade do espaço a ser utilizado pelo pedestre, os quais devem ser acessiveis, ter boa manutenção e arborização, favorecendo dessa forma, a diversidade dos usos e a dinâmica urbana. 60
59 SAKATA, F. G.. Paisagismo urbano: Requalificação e criação de imagens. São Paulo: Editora Universidade de São Paulo, 2011. p. 48.

60 Ibid., p. 19. 
Para tanto, seguem exemplos de ações produzidas para:

1. Organização de usos e fluxos e mudança da maneira de como os lugares são percebidos

Suzano: Rotatória junto à Avenida Governador Mário Covas Junior (Marginal do Una), tinha como função somente organizar o trânsito Fonte: Prefeitura Municipal de Suzano, 2008

Suzano: Esta rotatória é um exemplo de como um espaço livre muda a maneira de como um local pode ser percebido. Anteriormente à rotatória junto à Avenida Governador Mário Covas Junior (Marginal do Una), tinha como função somente organizar o trânsito, a partir de novas ações que se deram sobre ela, este espaço passou a guardar uma escultura elaborada pela artista plástica Tomie Ohtake, em comemoração ao centenário da imigração japonesa no Brasil, assumindo, dessa forma, um novo significado urbano, transformando-se, portanto, em um marco referencial da cidade Fonte: Arquivo Meng Tsai, 2008
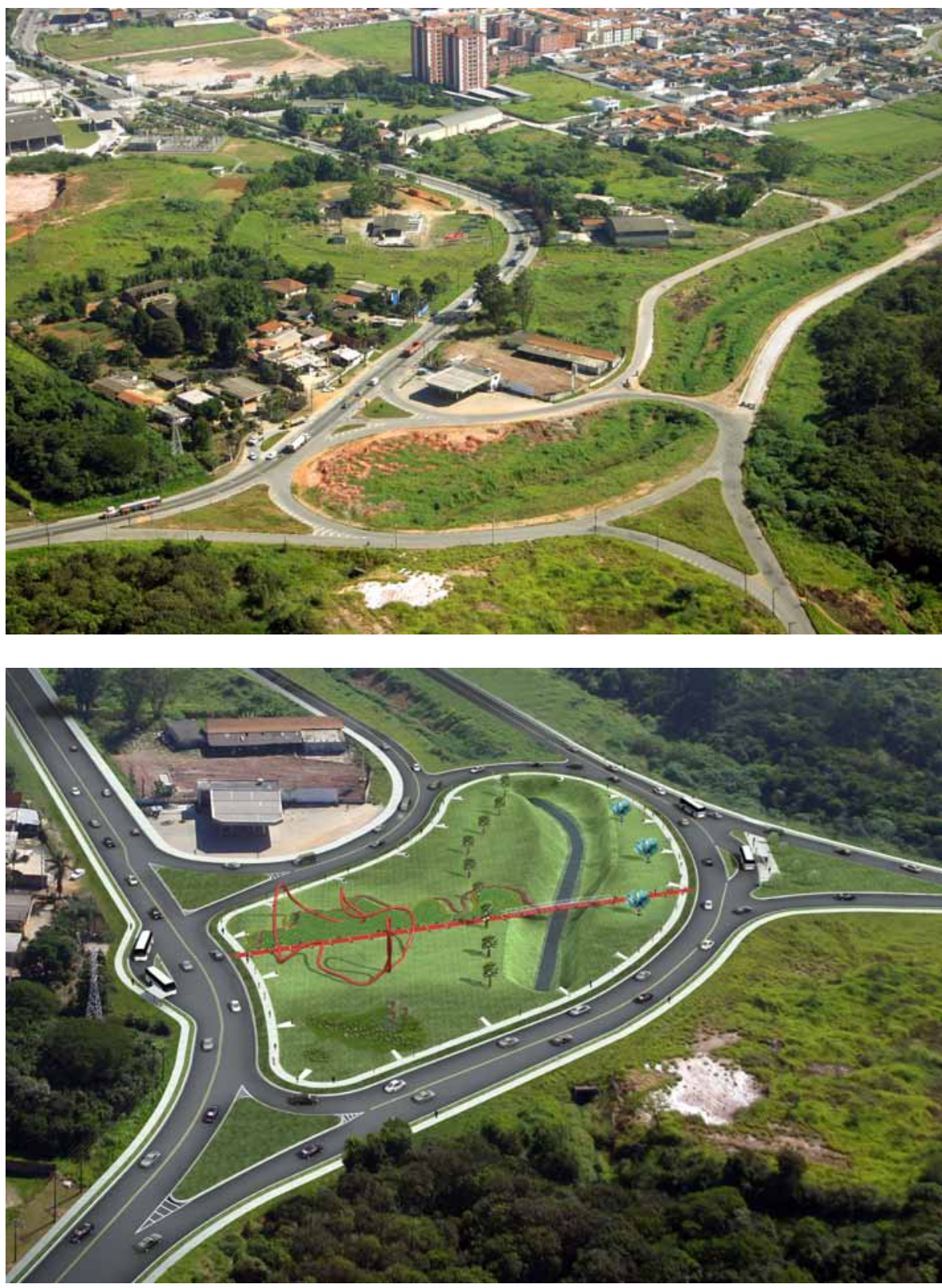
2. Fins eleitoreiros

Praça João Pessoa, onde se encontra a Igreja da Matriz do município de Suzano/SP. Os canteiros da praça foram todos replantados, próximo a períodos eleitorais Fonte: Prefeitura Municipal de Suzano, 2008
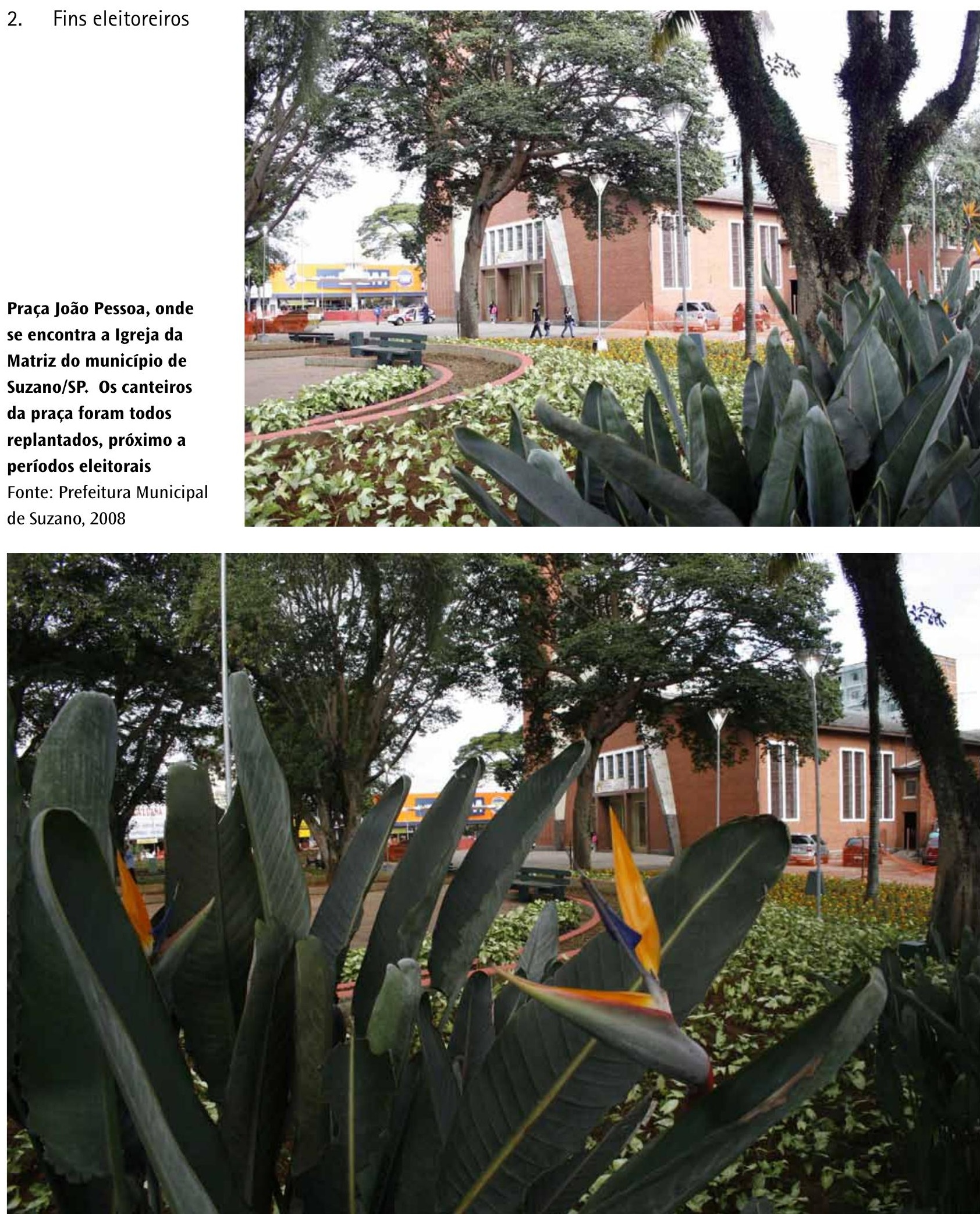
3. Proporcionar a melhoria da condição de vida das pessoas

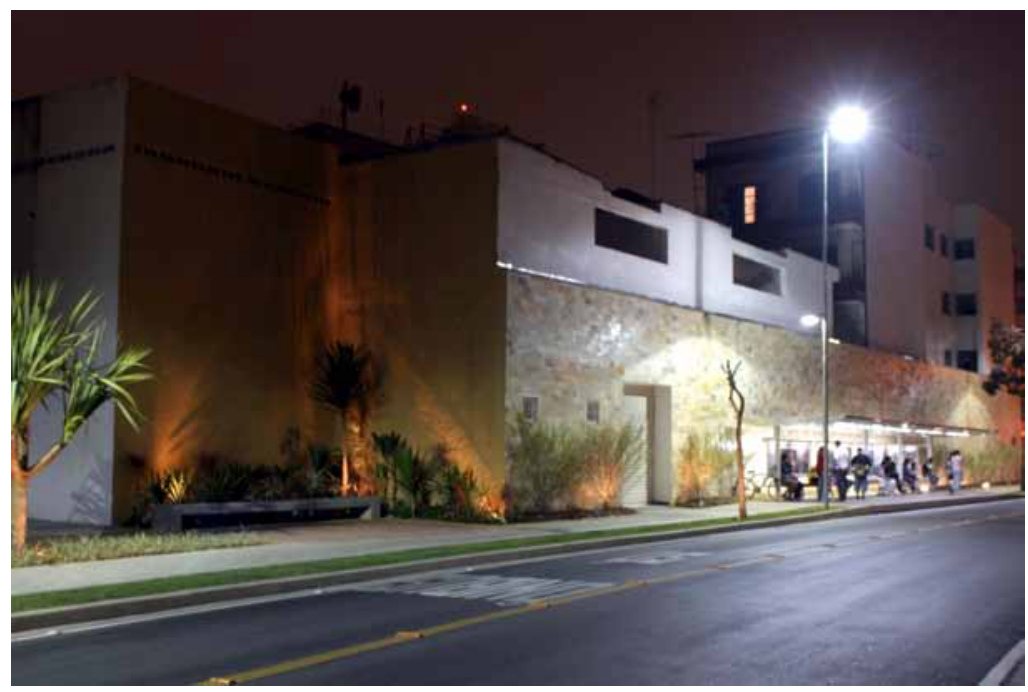

Suzano: A Parada Tiradentes trouxe várias melhorias para 0 local, nela o ponto de ônibus foi ampliado, o que permitiu que um número maior de pessoas ficasse abrigado, além disso, pisos táteis, como demonstra a imagem, foram inseridos para auxiliar os deficientes visuais

Fonte: Prefeitura Municipal de

Suzano, 2006

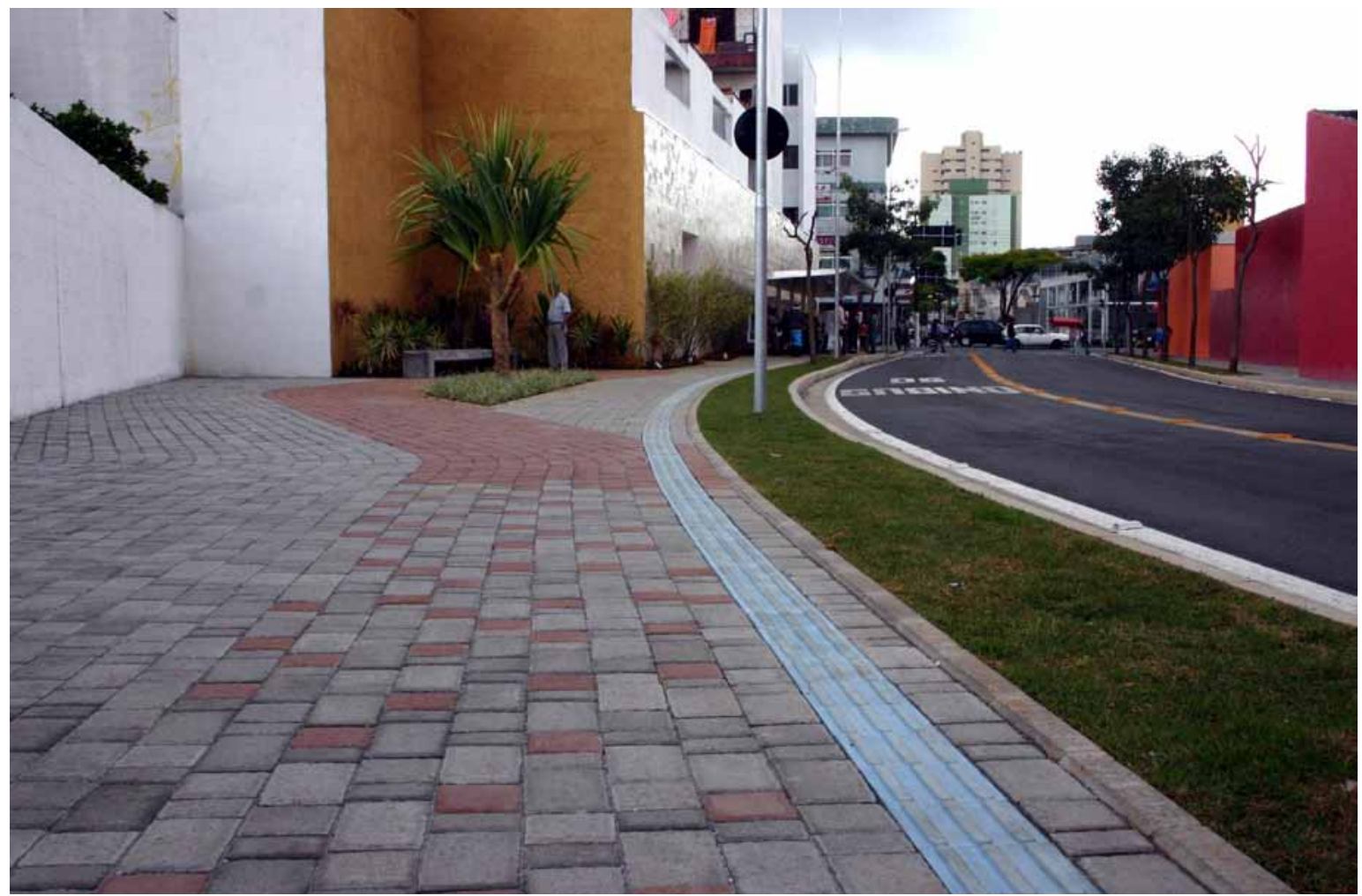



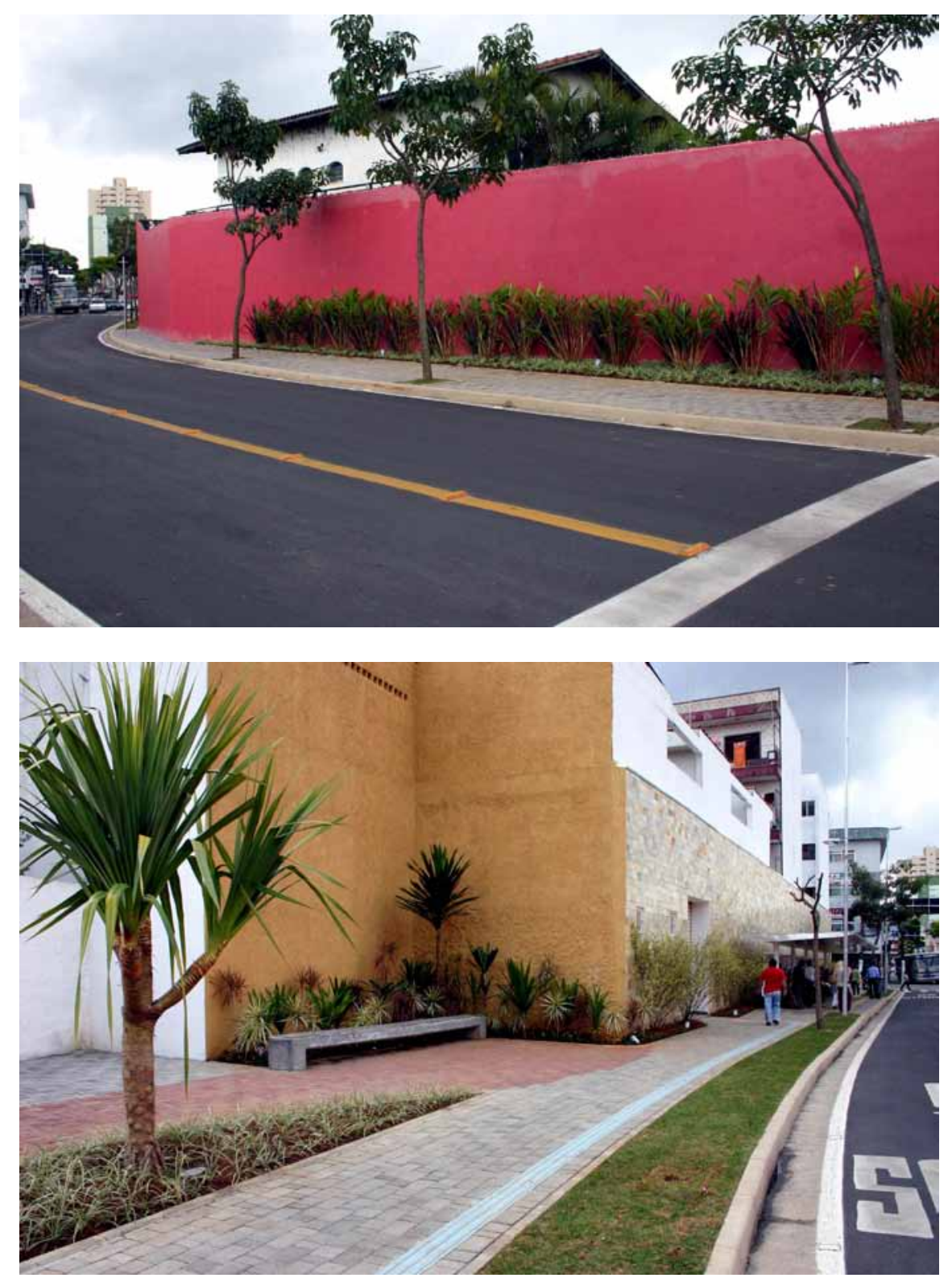

Suzano: Outros aspectos ainda foram trabalhados na Parada Tiradentes, como a inserção de canteiros, valorizando, dessa forma, o paisagismo no local e, consequentemente, o embelezamento da paisagem, além de um pequeno espaço voltado ao estar, para que a população pudesse permanecer no ambiente Fonte: Prefeitura Municipal de Suzano, 2006 


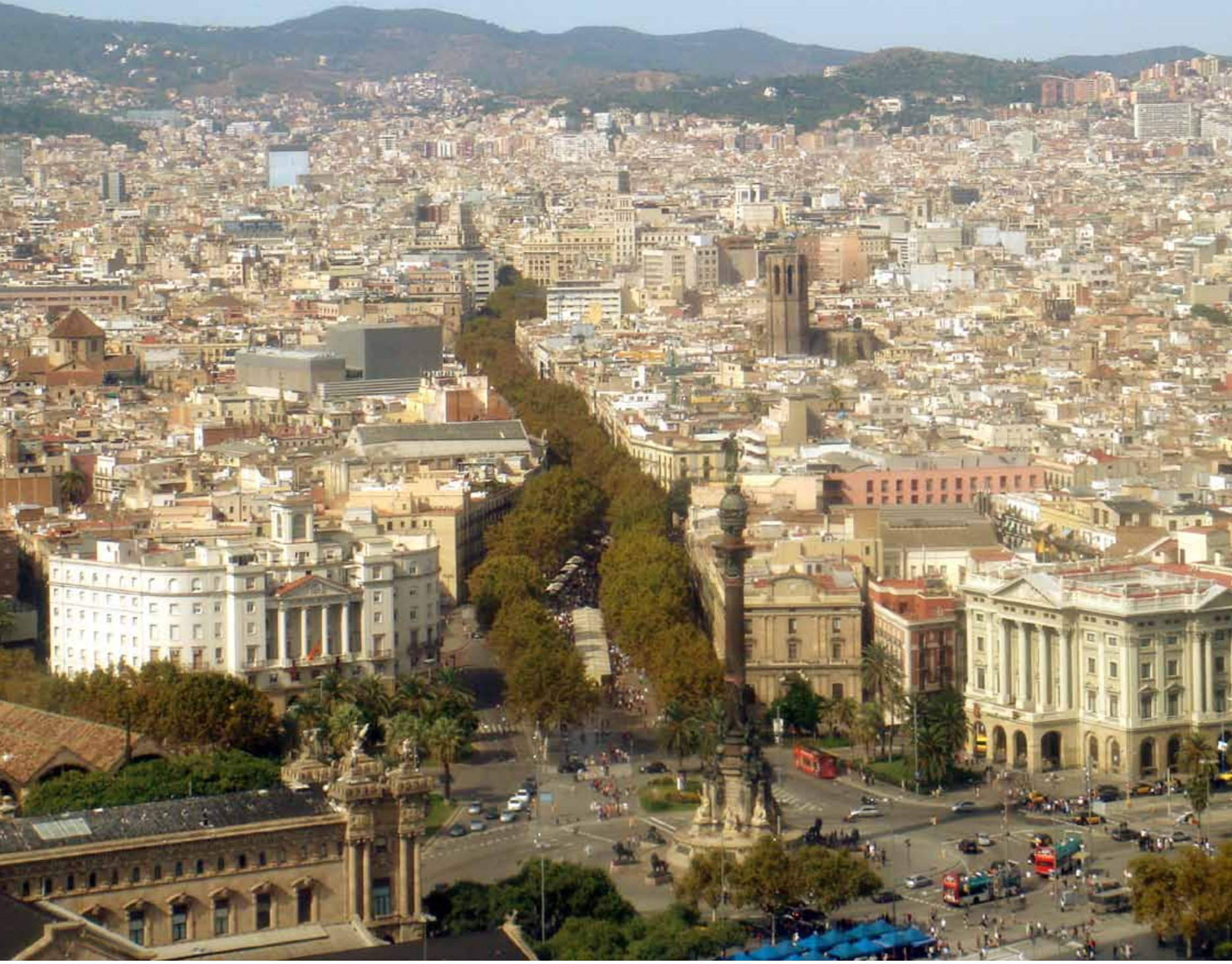

Barcelona/ Espanha - Rambla de Catalunya: As ramblas de Barcelona, em especial a Catalunya, são espaços que proporcionam grande melhoria na condição de vida das pessoas, por terem boa acessibilidade, promover a interligação entre importantes espaços e ainda por poder propiciar que grandes manifestações artísticas da cidade aconteçam nestes locais

Fonte: Arquivo Elvis Vieira, 2009 


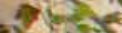


4. Atrair novos usos

Estados Unidos / Nova York - 0 Parque Linear High Line, antes um espaço que apenas tinha como função ser um viaduto, agora possui novos usos. Este local foi transformado em uma área, a qual guarda espaços de contemplação ao ar livre, bem como áreas vegetadas de grande expressão paisagística

Fonte: Arquivo Silvio Soares Macedo, 2010

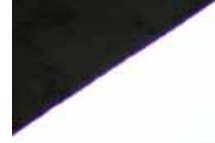


Assim, todos os exemplos comentados compõem parte de um (SEL) urbano, que é resultado de ações físicas e sociais. Fisicamente por estarem conectados entre si, principalmente pelo sistema viário e pelo sistema hídrico; e socialmente por permitirem que as relações cotidianas, políticas, culturais e artísticas se manifestem nos mais diversos elementos.

Verifica-se que a interligação física é apenas uma das inúmeras formas de interações que se estabelece entre os espaços livres, pois a própria essência da vida cotidiana urbana cria as relações importantes para a convivência em sociedade.

Nesse sentido, os espaços livres públicos podem ser analisados sob diferentes aspectos:

\section{Potencialidades ambientais e paisagísticas}

Para além das ações sociais e das articulações físicas possíveis, os espaços livres urbanos também cumprem uma importante função no que se refere à contribuição ambiental e paisagística.

Muitos deles se constituem em importantes estruturas ecológicas como as várzeas, matas e dunas, as quais são fundamentais na manutenção das dinâmicas ecológicas, contribuindo desta forma, para os serviços ambientais urbanos, no entanto, por inúmeras vezes estes elementos de paisagem não são incorporados a um sistema de espaços livres planejado. 


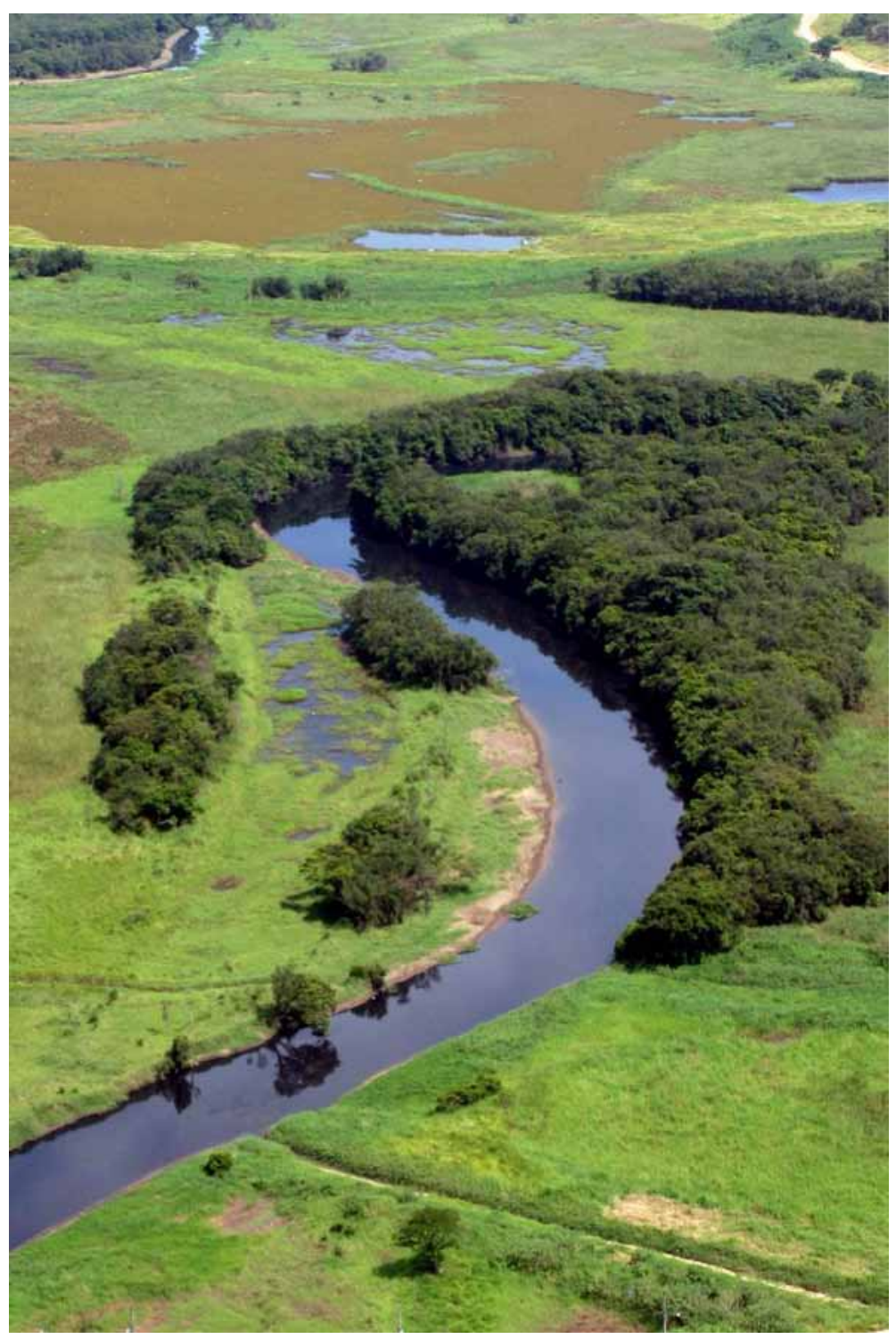

Suzano: Aspectos da Várzea do rio Tietê em Suzano/SP, desprovida de ocupações e com meandros preservados e fragmentos de mata ainda existentes. Este espaço é um típico exemplo que áreas com características ambientais e ecológicas podem fazer parte de um (SEL), a partir do uso destinado a ele. Neste caso a previsão é que seja implementado neste local o Parque Várzeas do Tietê Fonte: Wanderley Costa - Prefeitura Municipal de Suzano, 2008 
61 TÂNGARI, V.; ANDRADE, R.; SCHLEE, M. B. (Orgs.). Sistema de Espaços Livres: o cotidiano, apropriação e ausências. Rio de Janeiro: Universidade do Rio de Janeiro, 2009. p. 87.

62 MACEDO S. S. (Org.). Sistema de espaços livres da cidade contemporânea brasileira e a esfera de vida publica - considerações preliminares. São Paulo: IEB-USP, 2009. Disponível em: <http://egal2009. easyplanners.info/area05/5156CUSTODIO_Vanderli.doc>. Acesso em: 10 abr. 2011. p 3.

$63 \mathrm{lbid}$, p. 2.
Ressalta-se ainda que muitas propriedades públicas não se destinam necessariamente à vida pública, o que as impedem de participar de um sistema na forma de lazer ou como espaço para manifestações. No entanto, é possivel que elas participem do (SEL) a partir de princípios vinculados à preservação e à conservação.

"Por exemplo, um parque nacional, embora possa apresentar elevado interesse público e ser fruto de lutas políticas, possui na preservação ambiental seu papel de maior importância, sendo improvável seu uso para grandes manifestações políticas."6I

\section{Esfera pública e o sistema de espaços livres}

Entende-se que a esfera pública "envolve a produção cultural, a construção da cidadania, do interesse público, do bem público constituido socialmente diante do conflito de interesses individuais ou de grupos e, na cidade, teria a realização nos espaços públicos - ruas, calçadas, praças, parques e outros"62.

[...] Arendt (1991, p.15) qualifica a expressão vita activa como composta por três atividades humanas consideradas fundamentais: o labor, o trabalho e a ação. 0 labor diz respeito ao atendimento das necessidades do corpo biológico; o trabalho constrói a artificialidade do mundo e seria o responsável por sua duração além do período de vida humana; e, a ação seria a "[...] única atividade que se exerce diretamente entre os homens sem a mediação das coisas ou da matéria [...]"; portanto, a ação corresponderia à esfera da vida pública, a da realização da política stricto sensu, que desde a Antiguidade tem profunda relação com a organização do poder na cidade ${ }^{63}$.

Deixa-se claro que neste trabalho adotamos o conceito de esfera pública do Laboratório QUAPÁ - SEL, o qual divide a esfera 
pública em duas instâncias: esfera pública geral e esfera pública social.

A esfera geral compreende os espaços de autorrepresentação, espaço de visibilidade pública, enquanto a esfera social se caracteriza pelas relações econômicas de mercado, expressas pela crescente complexidade das sociedades capitalistas, podendo ser representada através das comunicações que acontecem nos espaços de jornais, cafés, entre outros 64 .

Outro aspecto importante que é considerado nesta reflexão é a desejável distinção entre esfera pública e espaço público. Nesse sentido trabalha-se "com a noção de espaço público enquanto espaço em que se realiza a esfera pública"65.

A esfera pública é tomada como toda a vida em público que remete à vida cotidiana, tenha ela caráter político ou não. Ou seja, caminhadas ao longo das calçadas, corridas nos parques, passeios familiares pelas praças e mesmo o encontro entre pessoas.

Já o espaço é entendido, como propôs Milton Santos, como um conjunto indissociável entre um sistema de objetos físicos e fixos e um sistema de ações que envolvem as relações sociais, 0 trabalho vivo e os fluxos 66 .

[...] Desta maneira não se abre mão de classificar como espaço público uma série de espaços de propriedade pública que interessam assim serem caracterizados e chamados - espaços públicos - salvaguardando sua natureza pública (de todos), ainda que não sejam necessariamente espaços da esfera pública, seja ela política ou geral. As reservas biológicas, por exemplo, caracterizadas como unidades de conservação altamente restritivas à presença humana, ainda assim são espaços de interesse público, e como tais merecem ser denominadas de espaços públicos de determinado território67.
64 TÂNGARI, V.; ANDRADE, R.; SCHLEE, M. B. (Orgs.). Sistema de Espaços Livres: o cotidiano, apropriação e ausências. Rio de Janeiro: Universidade do Rio de Janeiro, 2009. p. 88.

65 Ibid., p. 87.

66 SANTOS, M.. A natureza do espaço. São Paulo: Hucitec, 1996.

67 TÂNGARI, V.; ANDRADE, R.; SCHLEE, M. B. (Orgs.). Sistema de Espaços Livres: o cotidiano, apropriação e ausências. Rio de Janeiro: Universidade do Rio de Janeiro, 2009. p. 92. 

pode ser entendida sob dois aspectos:

i) como espaço de propriedade pública, independentemente de se prestar às ações próprias da esfera pública-política; e também ii) como espaço de apropriação pública, onde se realizam ações da esfera pública-política e da esfera pública geral, independentemente da propriedade ser pública ou privada 68 .

Assim, as manifestações da esfera pública em uma cidade acontecem, por exemplo, nas praças, nas ruas, nas calçadas, entre outros locais, ou seja: elas podem se expressar sobre os mais diversos espaços livres públicos de um território.

\section{Gestão do espaço público}

Pelo pais, em grande parte das cidades, não se observa a preocupação com relação à implementação, qualificação, bem como a conexão planejada dos espaços livres existentes.

Em grande parte dos municípios brasileiros, a não ser em alguns casos isolados, verifica-se a total ausência tanto na prática como nos discursos políticos, com relação à temática, apesar dos espaços livres serem considerados como infraestrutura essencial ao cotidiano das pessoas. Com isto, entende-se que no cotidiano das cidades as políticas voltadas a diálogos, constituição e qualificação dos sistemas, definitivamente não são prioritárias nos orçamentos públicos.

Observa-se que são raros os municípios que possuem espaços livres qualificados por toda a extensão do território, mesmo porque muitas gestões consideram que primeiro deve-se avançar em 
políticas que eles entendam ser fundamentais para o cotidiano da população, como a saúde, a educação, a habitação, para que em um segundo momento o sistema de espaços livres possa ser pensado e executado.

Entre outras consequências, os espaços livres, no que se refere às necessidades físicas, perdem, por exemplo, a oportunidade de terem incorporados os elementos naturais como participantes no seu projeto, e ainda vai-se além, pois ao remetermos a análise para as demandas sociais, verificamos que estas também não são alcançadas, simplesmente pelo fato da população não ser ouvida com relação aos seus anseios e/ou necessidades.

A conexão planejada dos espaços livres, dentre todos os aspectos, é o que tem a menor oportunidade de acontecer, pois ao considerarmos que há questões preliminares a serem superadas, como a própria implementação dos projetos pontuais, como de parques, praças e calçadas, imagina-se o quanto mais difícil deve ser para o Poder Público desenvolver planos de sistemas de espaços livres públicos e ainda implantá-los.

Somando-se a isto observa-se, em muitas cidades, que o Poder Público possui grandes dificuldades em até mesmo fazer a manutenção das áreas ajardinadas, da iluminação pública e pisos destes espaços.

Para além dos resultados voltados às questões de embelezamento do território, bem como das necessidades de lazer e recreação, observa-se que a ausência de investimento no sistema de espaços livres públicos é evidenciada nos crescentes desastres ambientais, os quais são verificados anualmente na época das chuvas torrenciais (alagamentos, deslizamentos, destruição e mortes), como as que ocorrem no início de cada ano no sul do país. ${ }^{69}$
69 MACEDO, S.S. \& QUEIROGA, E. F.. OS sistemas de espaços livres e a constituição da esfera pública contemporânea no Brasil. São Paulo: FAUUSP, 2011. p. 19. 
Ou seja, não investir em questões voltadas à urbanização, drenagem e fiscalização resulta diretamente no acontecimento de desastres ambientais como os que foram comentados.

Existe uma relação direta dos desastres ambientais com as temáticas voltadas à habitação e à drenagem, pois na medida em que se permite que as famílias habitem as áreas de várzea, este fato acaba resultando na impermeabilização do solo, a qual possui interligação direta com as enchentes, pois sabe-se que o sistema hídrico nas épocas de cheia necessitam de suas várzeas para que as águas possam espraiar-se e como elas estão ocupadas por habitações acabam sendo inundadas.

Com relação à fiscalização, no momento em que ela não encontra condição para ser efetivada, em decorrência da ausência de investimentos, não conseguindo dessa forma impedir que a população se instale nas áreas de várzeas e encostas, acaba por contribuir para que os desastres naturais aconteçam.

Além disso, dado ao fato de determinadas ações serem tidas como prioritárias, em detrimento dos investimentos a serem feitos para evitar os desastres ambientais (como a saúde e a educação que recebem por lei respectivamente, 15 e $25 \%$ dos recursos dos orçamentos municipais) $e_{1}$ ainda, considerando-se que o restante deve ser sempre dividido de acordo com as demandas indispensáveis com os demais órgãos da administração pública que compõem um governo como as Secretarias de Comunicação, Administração, Governo, Participação Popular, entre outras, que também necessitam de recursos, fica claro que pouco acaba por restar para que investimentos sejam feitos nos espaços livres públicos, a fim de se evitar os desastres naturais. 
Outro aspecto a ser considerado, vinculado às questões econômicas em nosso pais, é o baixo poder aquisitivo de determinadas camadas da população, com relação ao poder de compra, pois na medida em que as áreas de várzea são legalmente protegidas, elas acabam sendo vendidas pelo mercado informal para a habitação, o qual coloca o valor da terra a preços muito inferiores quando comparamos com o mercado formal.

Com isto, perde-se a oportunidade de atender tanto as demandas do cotidiano da população quanto a necessidade de preservar e conservar os recursos naturais, tirando das pessoas a possibilidade de estabelecer relações de sociabilidade fundamentais no seu dia a dia, assim como a de conviver com estes recursos. Ou seja, o Estado que possui o papel de gerenciar, normatizar e regular, deixa de cumprir o seu papel, no momento em que não consegue atender por motivos diversos as necessidades essenciais da população.

Tem-se como um fato que, no porte e na dimensão necessários, os recursos disponiveis em um governo em função das decisões políticas não são quantitativamente direcionados aos investimentos dos espaços livres como deveriam ser, de forma a atender às demandas de maneira adequada.

Elencar prioridades faz parte da administração pública, considerando-se que os recursos provenientes do tesouro, além dos vinculados, vindos do governo estadual e federal, são sempre insuficientes para atender todas as necessidades da população. Isto leva constantemente a escolhas voltadas às prioridades principais da sociedade, como a educação e a saúde. 
Contudo, é importante observar os inúmeros benefícios que a implementação de um sistema de espaços livres pode trazer para o território, considerando-se a habilidade que possuem de promover a melhoria do cotidiano da população, intensificar a imagem positiva que trazem para a cidade, ampliar o estímulo à continuidade da memória e da história, além de contribuir para com o embelezamento da paisagem.

Mas, o sucesso com relação aos benefícios que a existência de um sistema de espaços livres qualificado pode trazer para um território pode ser medido principalmente por um fator, que se trata da intensidade com que o espaço é usado pela população. Para que o uso seja intenso, é preciso atender às demandas da população, ou seja, o programa a ser desenvolvido no projeto arquitetônico deve estar vinculado às necessidades do entorno deste espaço livre.

Dessa forma, por um exemplo, se um loteamento possui uma população de idosos, entende-se que devam existir atividades vinculadas à bocha e ao xadrez; se trata de um conjunto de adolescentes, que então se tenham campos de futebol e pistas de skate; se a demanda está vinculada à saúde, que sejam contempladas pistas de caminhada; ao existirem fatores culturais e históricos ligados a uma determinada comunidade, como a japonesa, espera-se que ele contenha suas memórias e, por fim, ao se ter paisagens naturais com expressiva capacidade de contemplação, imagina-se que os espaços sejam postos a fim de que se possa desfrutar das belezas cênicas.

Ou seja, é importante observar que os espaços livres são feitos para as comunidades, já que o uso será delas e, portanto, seus anseios e tradições devem ser contemplados. 
Outro aspecto ainda a ser considerado, com relação a estes locais, trata-se da capacidade da gestão do Estado e da população em fazer os serviços de manutenção dos espaços livres, pois o que se vê com frequência é que após sua inauguração os órgãos administrativos possuem grande dificuldade em mantê-los, com relação à limpeza, poda de árvores, ao estado do mobiliário urbano, iluminação e paisagismo ${ }^{70}$.

Ou seja, diante de toda a análise feita, percebe-se que se por um lado existem administrações realmente comprometidas em meIhorar o cotidiano da população, por outro, vê-se que o predomínio é de ações sobre os espaços livres públicos que visam resultados imediatistas, com vistas a resguardar principalmente a capacidade de eleição, reeleição e sucessão de governadores, prefeitos e vereadores, tendo como foco a conquista ou a permanência no poder.

Em função do foco puramente vinculado às eleições, por muitas vezes os espaços recebem uma simples inserção de espécies ornamentais, objetivando única e exclusivamente valorizar a estética de modo que se crie imagens urbanas atraentes visando captar votos. Dessa forma, o embelezamento do espaço urbano passa a ser um dos fatores de promoção do poder público perante os cidadãos e, portanto, os eleitores. Ou seja, cativá-los por obras "cosméticas", que por vezes não trazem transformações reais, faz parte do cotidiano público brasileiro, sendo que ações estruturantes, as quais de fato atendam às demandas da totalidade da cidade ou das áreas mais carentes são, por vezes, deixadas de lado.

Assim, finais de mandato são oportunidades únicas para o desperdício, sendo comum o aparecimento de obras incrementais de embelezamento, sem nenhuma demanda específica.
70 Esta dificuldade acontece dado ao fato de não se contabilizar dentro dos custos totais da administração pública, os valores que devem ser destinados à manutenção destes espaços, ou seja, pensa-se no valor da obra para que ela seja executada, porém não em como ela será mantida. 
No entanto, entende-se que o final de um mandato, na verdade, pode ser considerado o início de um próximo, e que por isso os planos devem ou deveriam continuar sendo elaborados para que o gestor seguinte tenha em suas mãos o planejamento do território preparado para a sua atuação. Em resumo, perde-se, dessa forma, a possibilidade de implementar planos e projetos que realmente sejam eficazes e promovam a transformação do território dentro de uma política de longo prazo que contemple a esfera pública.

Com isto, acabam não sendo resolvidas demandas sociais voltadas à criação de políticas públicas realmente eficazes, como 0 desenvolvimento de planos que visem a implementação de sistema de espaços livres, os quais possuem a capacidade de transformar realmente a paisagem urbana, valorizando paralelamente os elementos naturais de um território, como as águas e as matas.

Evidentemente, não é possivel que uma determinada gestão pública invista seu mandato de quatro ou oito anos somente no desenvolvimento de planos, objetivando a criação da cidade ideal, perfeita ou até mesmo utópica, imaginando-se que existem recursos financeiros infinitos para que tudo possa ser resolvido, partindo-se do princípio que eleitores, políticos, partidos, associações, instituições, assembléias, coordenações e comissões cobram e necessitam de resultados imediatos.

Sabe-se que, embora o ideal seja trabalhar primeiramente no desenvolvimento dos planos para que depois eles sejam realizados, isto pode se tratar de pura ilusão, para uma gestão pública perante a realidade quanto às urgências. No entanto, na prática, entende-se que não há nada de fato, que impeça o desenvolvimento compartilhado dos dois. 
A falta de capacidade, interesse e gestão, além do desconhecimento por parte de alguns gestores da necessidade de se fazer planos que contemplem inclusive a participação popular também acabam sendo responsáveis pela não elaboração dos planos.

Ainda que seja compreensivel que os planos devam ser premissas para o desenvolvimento de ações e obras, entende-se que a execução não inviabiliza a elaboração destes, que deveriam ter como meta o planejamento do território dentro de uma longa escala temporal.

No entanto, compreende-se que os diversos segmentos da sociedade promovem pressões para que obras sejam feitas de maneira imediata, pois as suas necessidades são urgentes.

Ou seja, a cada novo mandato que se inicia, o qual precede outro, em que os planos não foram desenvolvidos, a situação se agrava, pois as obras acabam tendo que ser desenvolvidas paralelamente, ou então perde-se tempo durante a gestão para que primeiro sejam elaborados para que depois as ações sejam efetivadas $^{7 !}$.

Dessa forma, o que se verifica é que as transformações que visam espaços de extrema qualidade urbanística e ambiental somente vão ocorrer através da implementação de ações urbanas, que por muitas vezes não ocorrem em uma gestão, mas podem acontecer nas próximas, e para que isso se efetive, é necessário haver algum tipo de planejamento a longo prazo e, portanto, continuado.

No entanto, apesar dos inúmeros benefícios que o planejamento apresenta para um território, há que se ter ressalvas, pois a exemplo dos planos diretores, que em grande parte são consti-
7I Por outro lado, quando um governo, subsequente a uma outra gestão, encontra planos já realizados, sem dúvida alguma, passa a ter a oportunidade de promover uma gestão mais segura e eficiente, em função do fato de poder se pautar nas diretrizes já elaboradas, a exemplo de planos vinculados ao saneamento ambiental, onde estabelecem diretrizes para que a universalização dos serviços voltados ao abastecimento de água e ao esgotamento sanitário possa ser atingida em um determinado recorte temporal. 
72 VILLAÇA, F.. Dilemas do Plano Diretor. Disponível em: $<$ http://www. ongcidade.org/site/arquivos/artigos/ dilemas436f9e94d59fb.pdf $>$. Acesso em: 31 de abr. 2011.

73 Ibid., p. 245.

74 Idem. tuídos de uma enorme lista de enunciados de políticas, diretrizes, programas e indicações gerais diversas, sabe-se que a maioria deles, se por um lado não assegura qualquer comprometimento, nem mesmo político, por outro remete qualquer operacionalização para um futuro indefinido ${ }^{72}$.

Em muitos momentos os planos são pretensamente colocados por gestores públicos e técnicos como "todos poderosos", com uma "suposta missão de "integração" ou "coordenação", quer inter-setorial, quer na esfera interna da administração municipal, quer entre distintos niveis de governo ${ }^{73}$. Ou seja, entende-se que planos como os de saneamento, de restauração ambiental, bem como "o plano diretor não são peças puramente científicas e técnicas, mas peças políticas, vinculadas tão somente aos poderes e atribuições de um governo municipal".74

E sendo assim, o que se observa na prática é que por mais embasamento técnico, científico e político que os planos tenham, além de participação popular, as articulações políticas são fundamentais na sua aprovação junto às câmaras de leis, bem como para sua implantação.

Ou seja, é preciso haver continuidade e decisão política tripla, entre legislativo, executivo, além do respaldo do Ministério Público. Se não for assim, sem dúvida eles terão sido apenas um exercicio de conhecimento junto ao respectivo território de estudo.

Entende-se, portanto, que a solução final está pautada nos acordos políticos entre o executivo e o legislativo, que devem acontecer para que os trabalhos e ações sejam realmente efetivados. 
Estes acordos, entretanto, perpassam pela gestão política partidária, considerada de fundamental importância e completamente estratégica para a consolidação das políticas. $\mathrm{Ou}$ seja, com isto entende-se que a gestão de um território se dá não a partir do momento em que se elege um candidato, mas sim em instantes anteriores como as "prévias" onde o processo eleitoral começa a ser dialogado 75 .

Com relação ao poder executivo, as coligações partidárias são realizadas a fim de potencializar um determinado partido, garantindo dessa forma que ele seja detentor do poder, como prefeito, governador ou presidente.

Quanto ao legislativo, os partidos trabalham para se ter 0 maior número de vereadores, deputados e senadores, nas casas de lei, resguardando dessa forma, a maioria dos votos no que se refere aos projetos de leis, elaborados pelo executivo. Ou seja, é a somatória de forças entre o executivo e o legislativo que irá garantir que os planos desenvolvidos sob bases técnicas sejam aprovados e efetivados dentro do território.

Com isto, dentro de determinadas administrações, a gestão técnica vinculada aos órgãos administrativos, tais como as Secretarias e Ministérios, passam a ter parte das políticas desenvolvidas em seus gabinetes em função dos acordos partidários efetivados e não da real demanda necessária para atender a população.

Dessa forma, objetivando-se que um território possa avançar na gestão de políticas, as câmaras municipais, as assembléias legislativas e o senado, precisam estar completamente acordados com o executivo, para que os projetos, planos e ações voltados ao
75 Todo o processo governamental, de maneira embrionária, tem seu início nas "prévias", ou seja, nas eleições que são feitas dentro dos próprios partidos para decidir qual dos candidatos internos irá disputar as eleições com a oposição. 
${ }^{76} \mathrm{E}$, ainda, há que se considerar $\mathrm{o}$ tempo que estes acordos políticos conseguem se dar, pois por diversas vezes estes se estendem por tanto tempo que, a exemplo dos planos diretores, acabam desatualizados com relação à realidade do território. Para além das desatualizações com relação aos planos e a realidade local, tem-se também as questões vinculadas a perda de recursos e a morosidade com relação à tomada de decisões que também acontece em função das políticas partidárias, ou mesmo, em função de se optar por não entrar em embates com grupos sociais específicos.

77 MACEDO, S.S. \& QUEIROGA, E. F.. Os sistemas de espaços livres e a constituição da esfera pública contemporânea no Brasil. São Paulo: FAUUSP, 2011, p. 18.

78 MACEDO, S.S.. Quadro do paisagismo no Brasil. São Paulo: FAUUSP, 1999. transporte público, aos resíduos da construção civil, ao uso do solo, entre outros, se efetivem.

A vida da população passa a ser, dessa forma, refém da política partidária e municipal, que se estabelece de acordo com os interesses coletivos de um grupo ou de grupos, ou até mesmo de interesses individuais, prejudicando de maneira agressiva o desenvolvimento de um território ${ }^{76}$.

Assim, em função dos acordos, por muitas vezes países, regiões, estados e municípios, deixam de ser contemplados com ações fundamentais às necessidades essenciais de um povo.

\section{Projetos}

"Para tanto, os espaços livres da cidade devem ser muitos, diversificados, tratados paisagisticamente, arborizados (evidentemente não necessariamente todos), equipados, bem mantidos e bonitos." 77

Observa-se dessa forma que qualquer plano proposto para 0 território pode induzir a projetos sobre os espaços livres que contemplem ${ }^{78}$ :

\section{A. Ações}

- cosméticas - constituindo-se em espaços meramente decorativos de apropriação social, que colaboram para a esfera pública;

- de sobreposição - que tenham a capacidade de serem reinventados como espaço de visibilidade;

- $\quad$ mistas - que incorporam as ações comentadas acima. 
Suzano: A Praça João Pessoa, onde se localiza a Igreja matriz do município, pode ser classificada como um espaço de sobreposição, considerandose que esta, por vezes, recebe inserções de espécies no intuito de garantir visibilidade Fonte: Prefeitura Municipal de Suzano, 2008
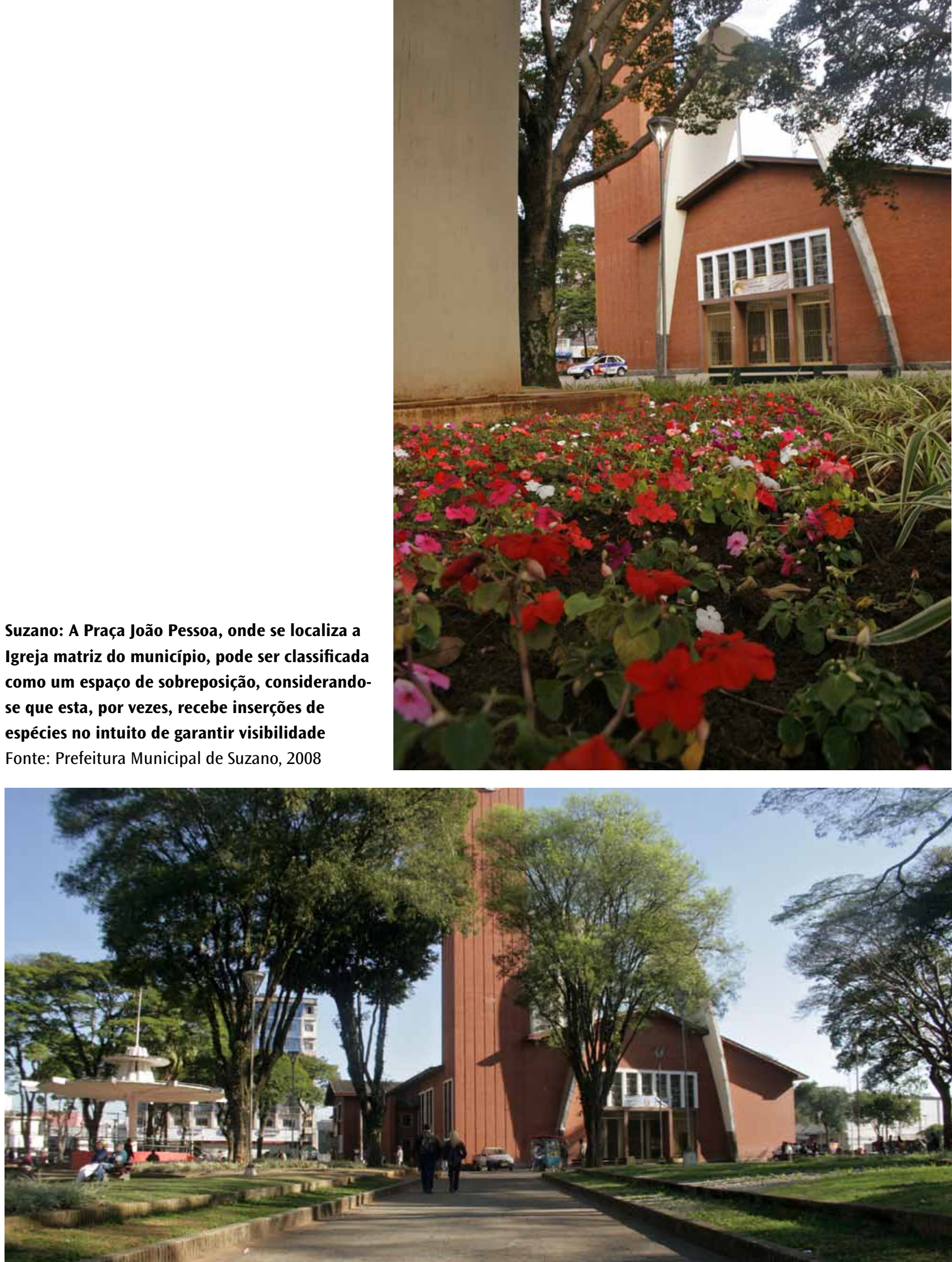


\section{B. Abrangências}

- para as atividades cotidianas;

- $\quad$ para a recreação de grandes segmentos da população;

- para o acesso.

C. Qualificações

- $\quad$ FUNCIONAIS - que estão ligadas à localização com programas adequados;

- $\quad$ ESTÉTICAS - voltadas a cada tempo e que apresentam valores com caracteristicas puramente sociais;

- $\quad$ AMBIENTAIS - as quais estão associadas às dinâmicas ecológicas existentes.
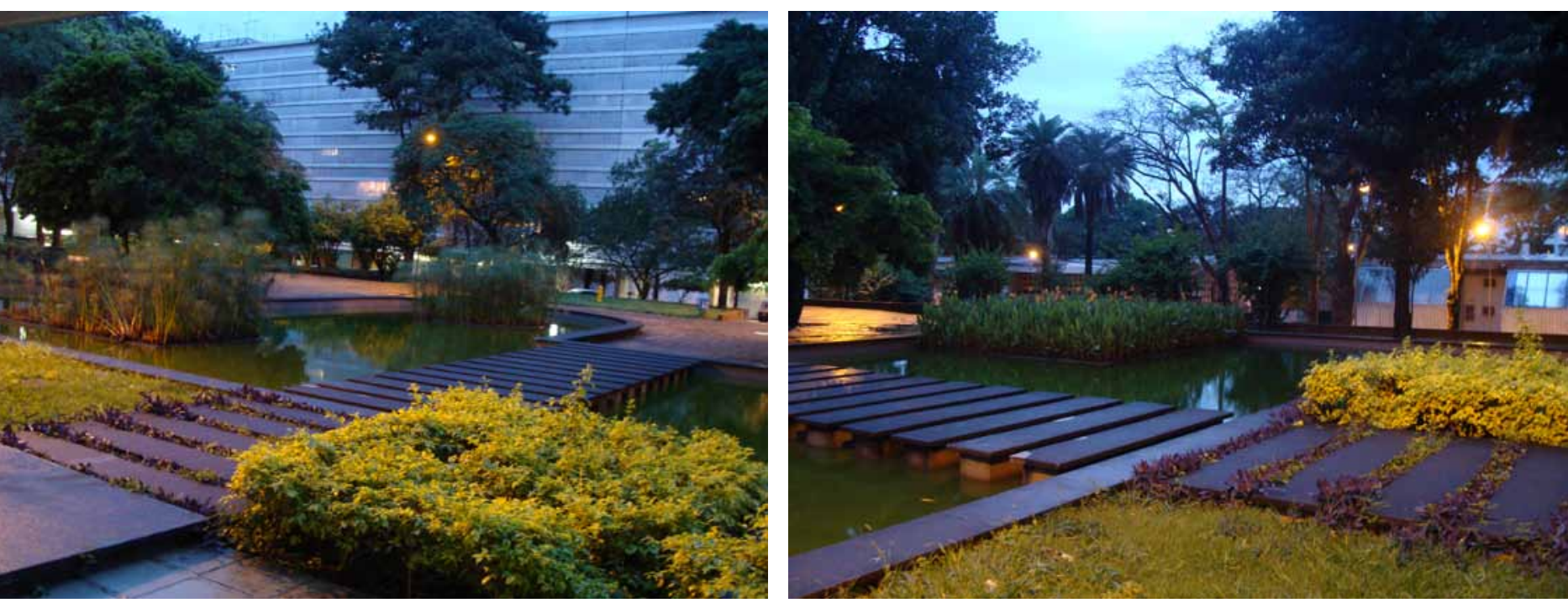

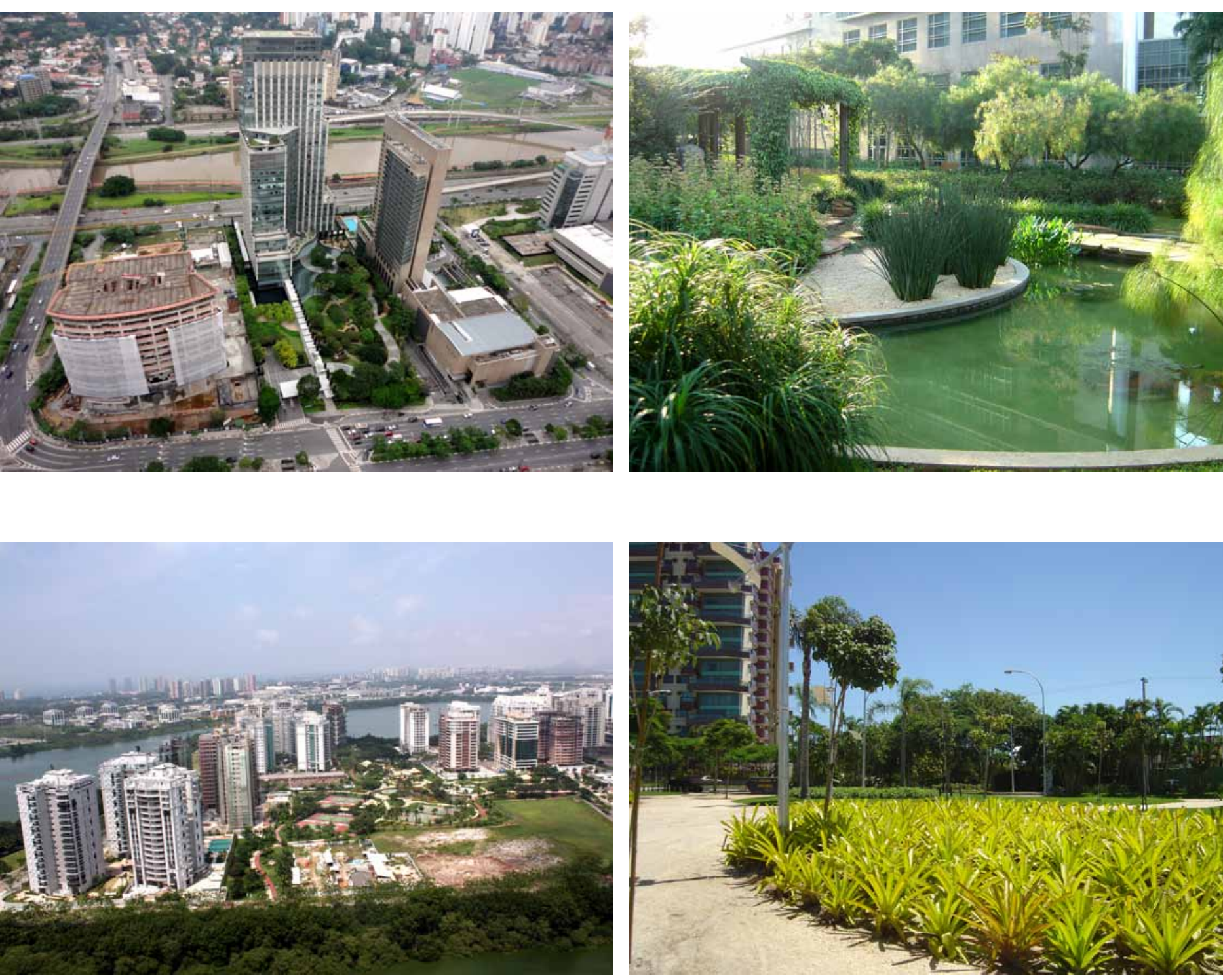

Como exemplo de qualificação estética, temos os espaços localizados respectivamente em Brasília, São Paulo e Rio de Janeiro, que por sua vez utilizam elementos como água e vegetação para obter a qualificação ideal voltada à estética Fonte: Arquivo Silvio Soares Macedo, 2009 


\section{Significados}

- $\quad$ estruturais - que organizam a totalidade do espaço urbano ou têm uma função definida para toda a população;

- complementares - que abriga as atividades cotidianas.
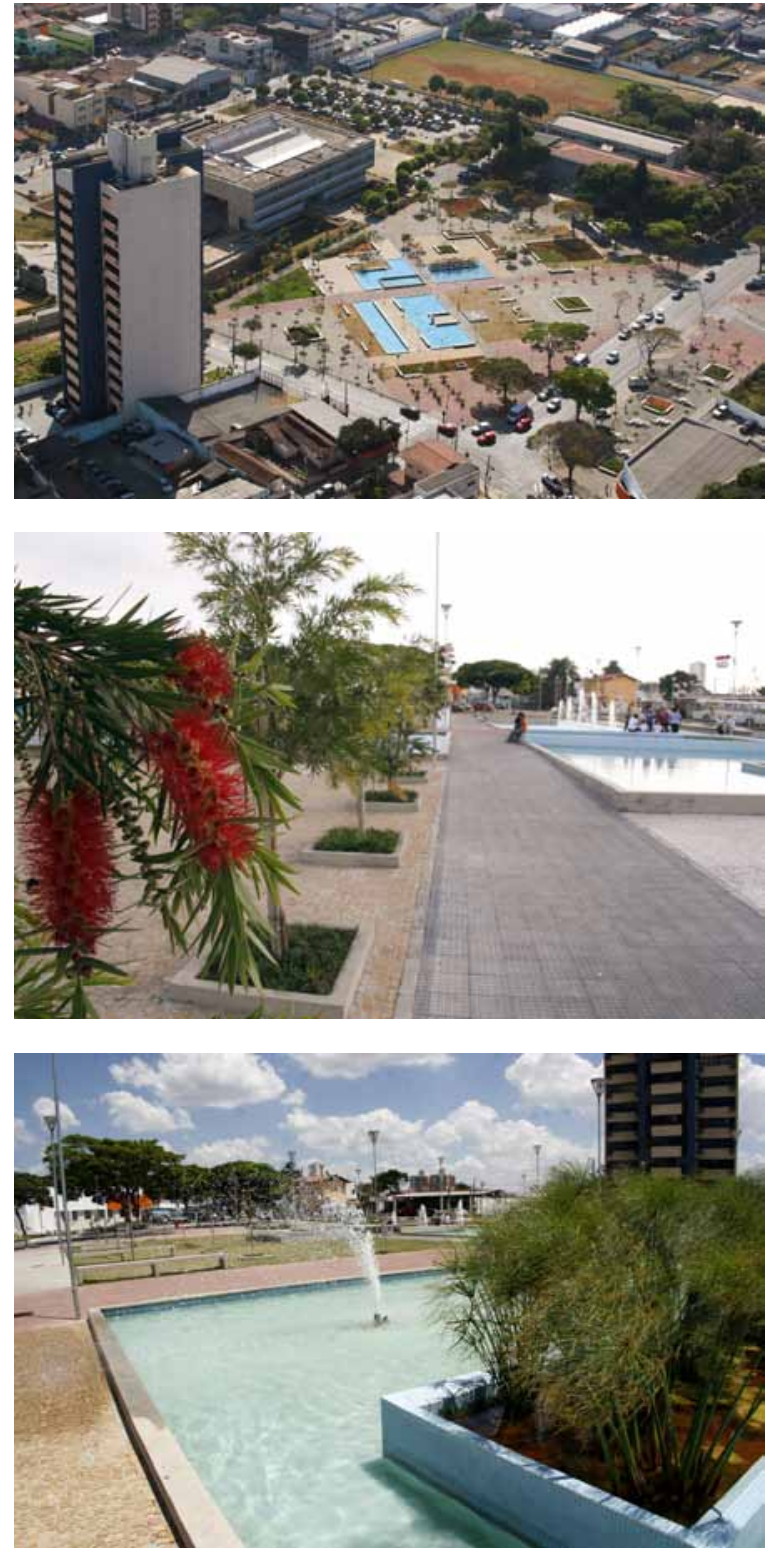
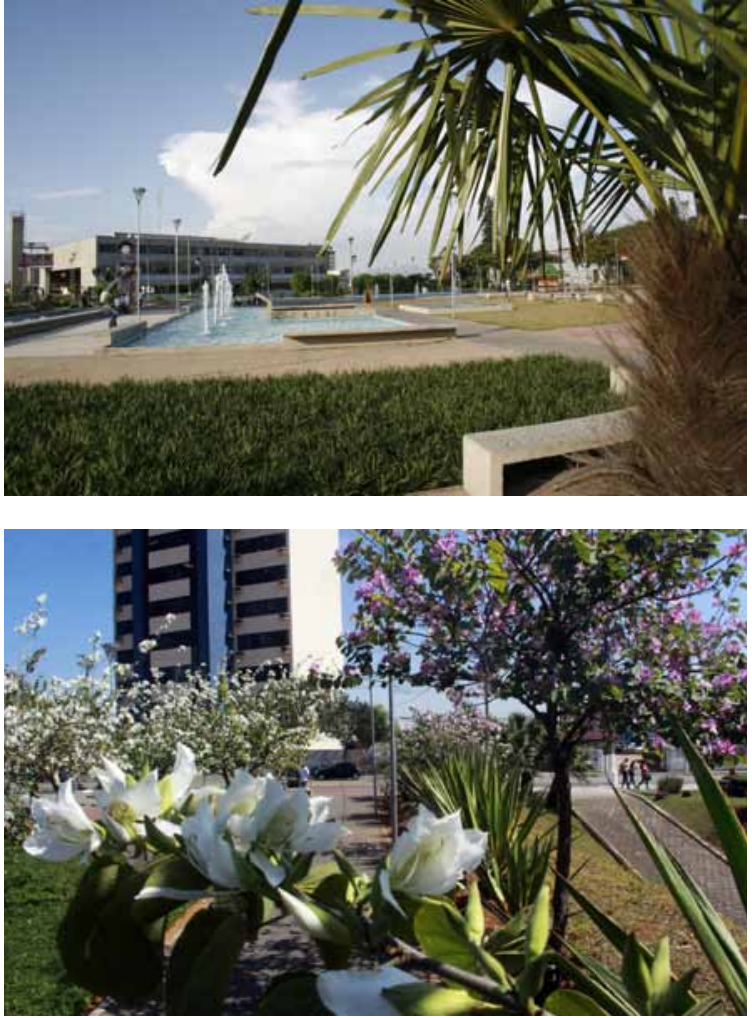

Suzano: Como exemplo de significados estruturais tem-se a Praça Cidade das Flores, considerandose que o espaço pré-existente era utilizado como estacionamento. Neste momento o local atende a atividades voltadas ao lazer e a recreação Fonte: Wanderley Costa - Prefeitura Municipal de Suzano, 2008 


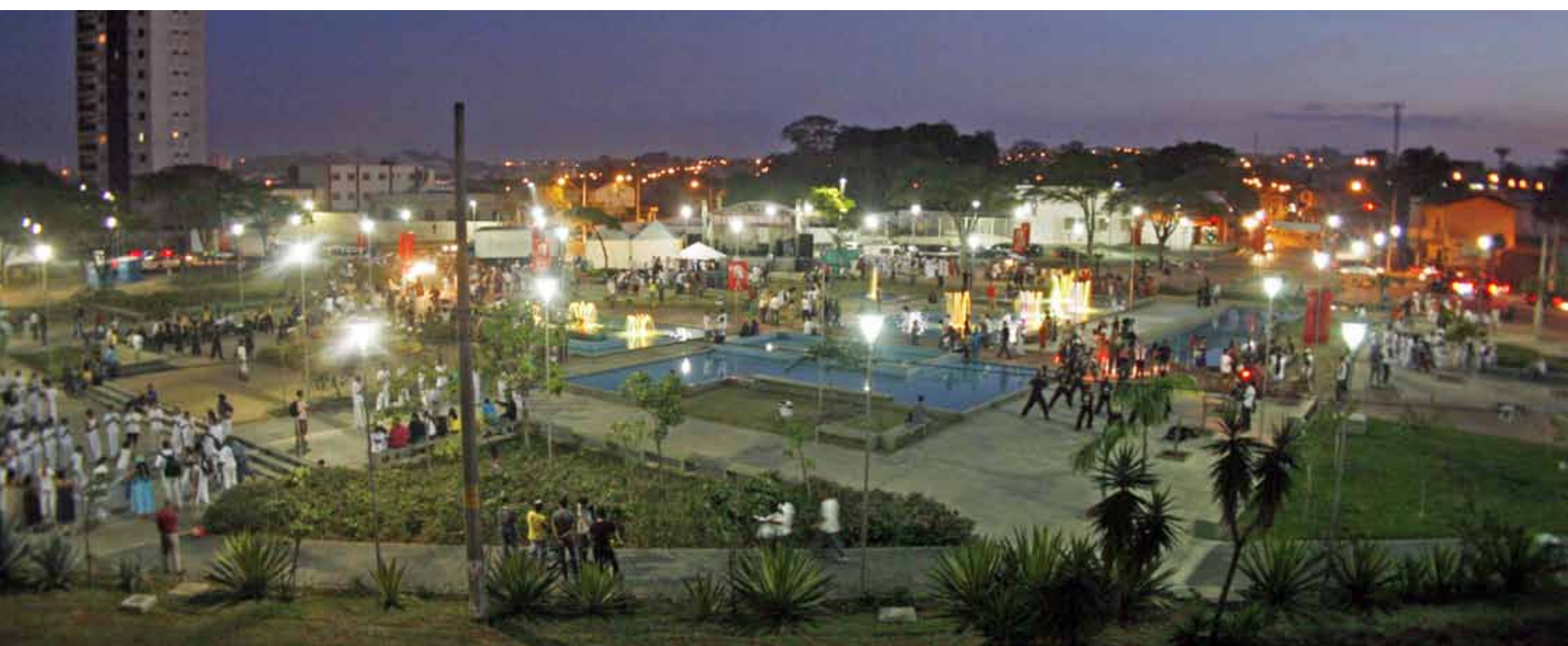

Suzano: A Praça Cidade das Flores estimula atividades de todos os tipos, a exemplo da "Roda de Todos os Santos", que possibilita o estabelecimento de trocas de experiências, vivências, sonhos e ansiedades da sociedade Fonte: Wanderley Costa - Prefeitura Municipal de Suzano, 2011 
ENTRE AS SERRAS: SISTEMA DE ESPAÇOS LIVRES PÚBLICOS, UMA REFLEXÃO PARA SUZANO 


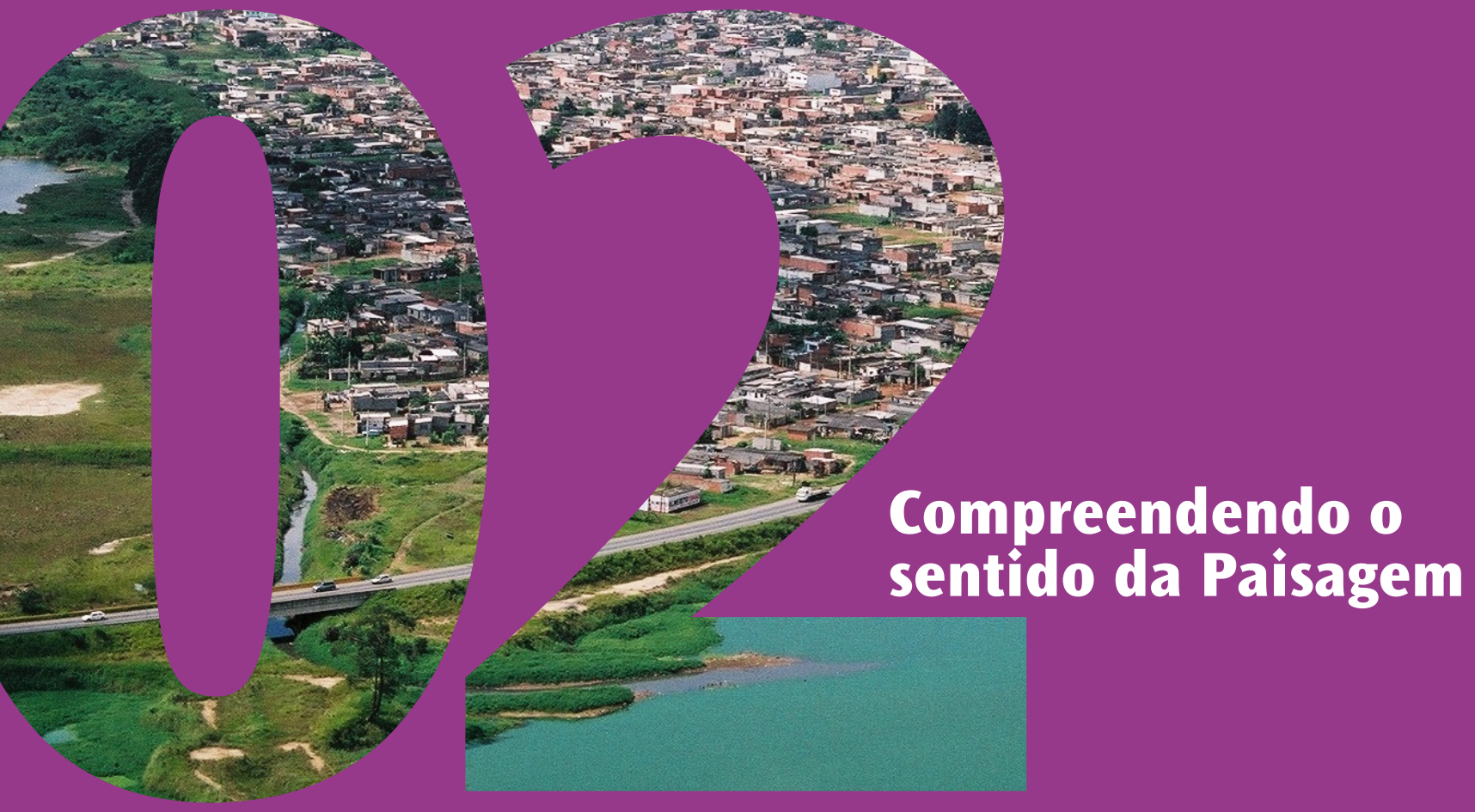





\section{Contextualização regional}

0 território municipal de Suzano, situado dentro da Bacia Hidrográfica do Alto Tietê Cabeceiras, está em área de domínio de Mata Atlântica, contendo uma porção de várzea do rio Tietê bastante intacta no lado norte, possuindo 73\% de seu espaço inserido em Área de Proteção dos Mananciais - APM da metrópole paulistana.

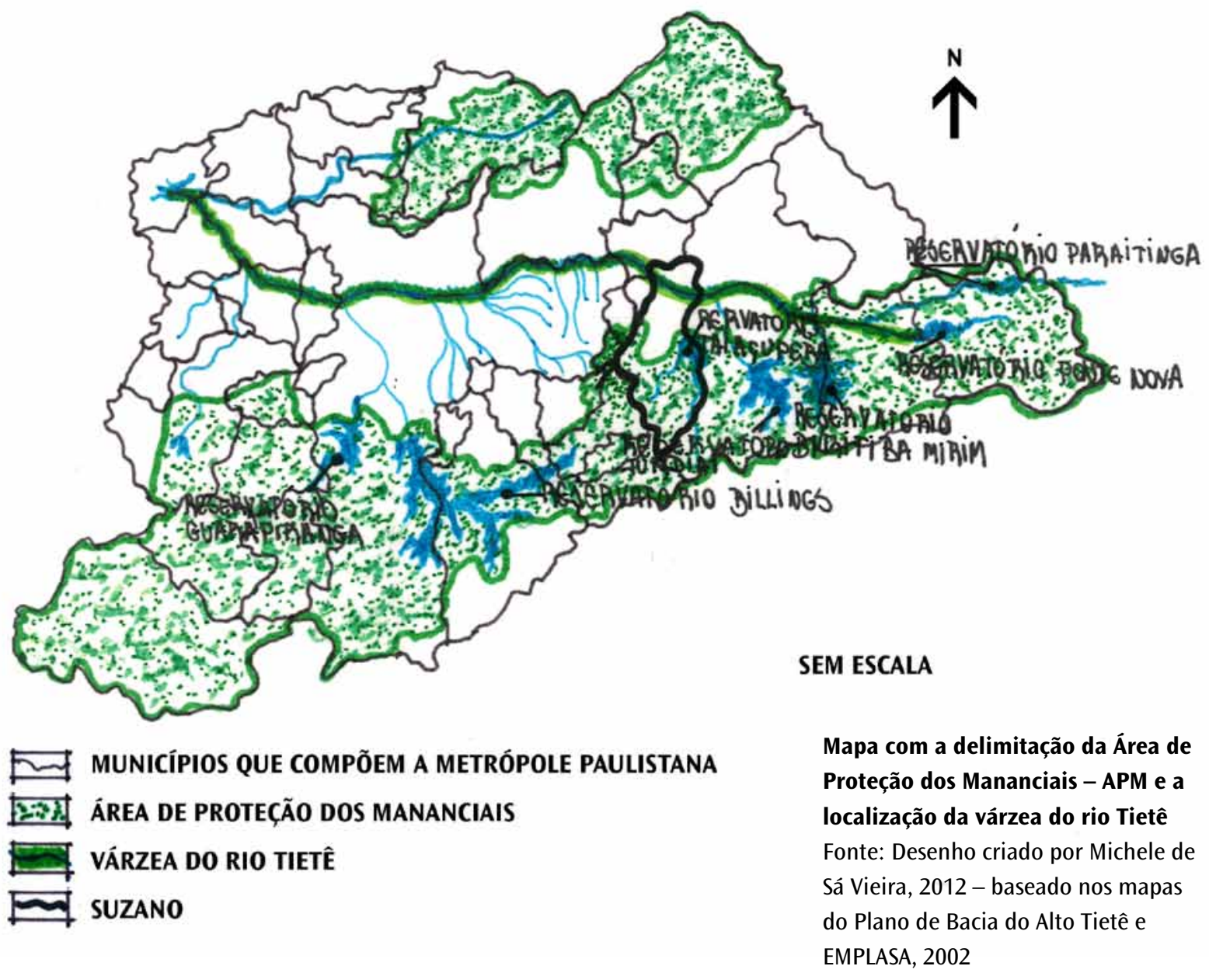


Região Metropolitana de São Paulo - Setor Leste: Área de Proteção dos Mananciais e mancha urbana até 2002. Em Suzano as ocupações, que se deram nesta área protegida por legislação estadual, ocorreram causando a destruição de diversos sistemas hídricos $\mathrm{e}$ fragmentos florestais Fonte: EMPLASA, 2002 - sem escala

Região Metropolitana de São Paulo - Setor Leste: Observase que as ocupações urbanas na Região Metropolitana de São Paulo estão concentradas ao norte, no entanto, apesar de protegida por lei, a Área de Proteção aos Mananciais, localizada ao sul, encontra-se bastante ocupada, processada e remodelada pela população Fonte: EMPLASA, 2002 - sem escala
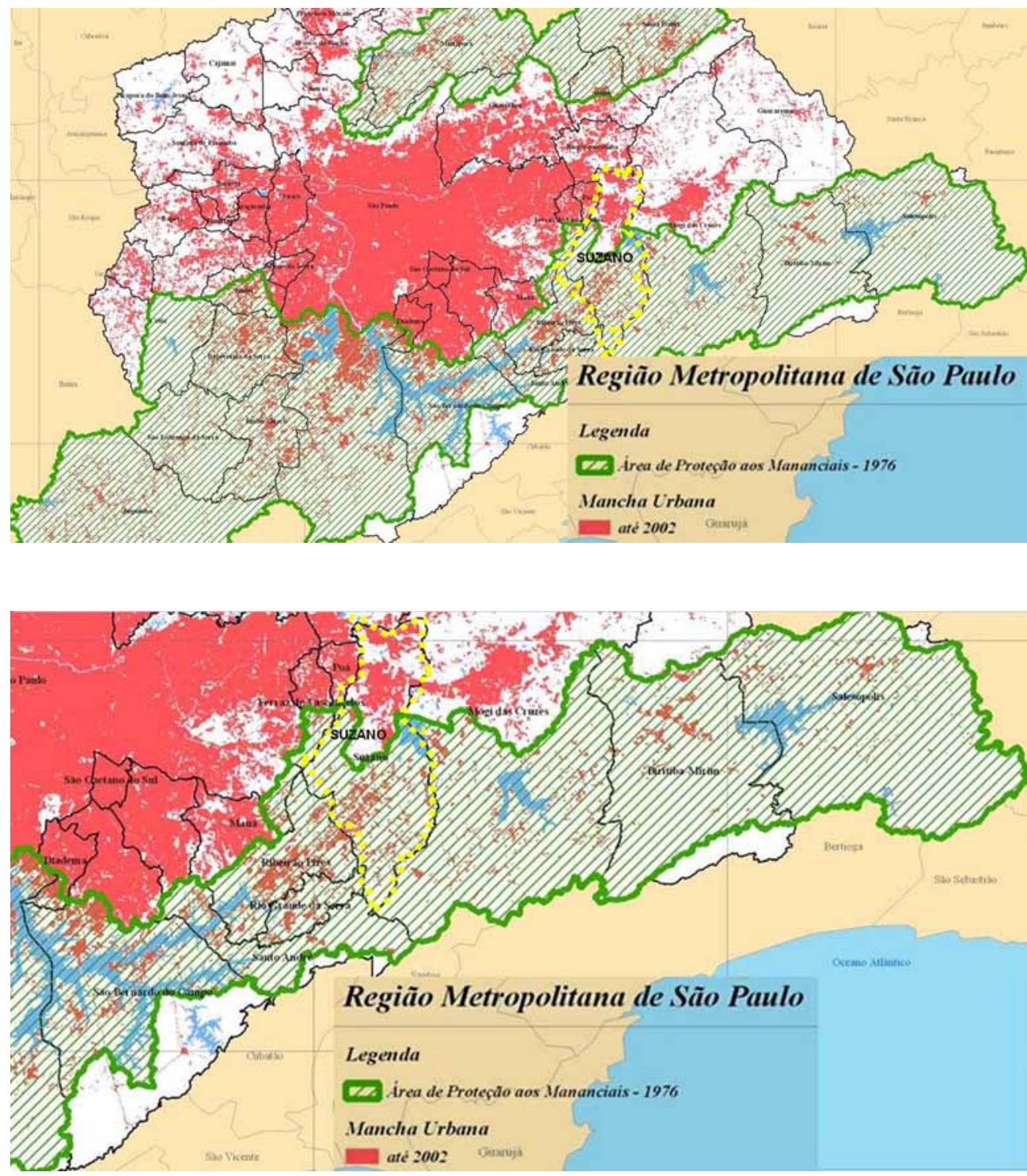

Paisagisticamente caracteriza-se por possuir intensa vegetação natural por todo o território, entre estas, com grandes fragmentos florestais naturais ainda bem conservados, meandros e vegetação preservados, em específico ao longo da várzea do Tietê, muitas áreas de agricultura, além da represa de Taiaçupeba, responsável pelo abastecimento de água do municipio. 


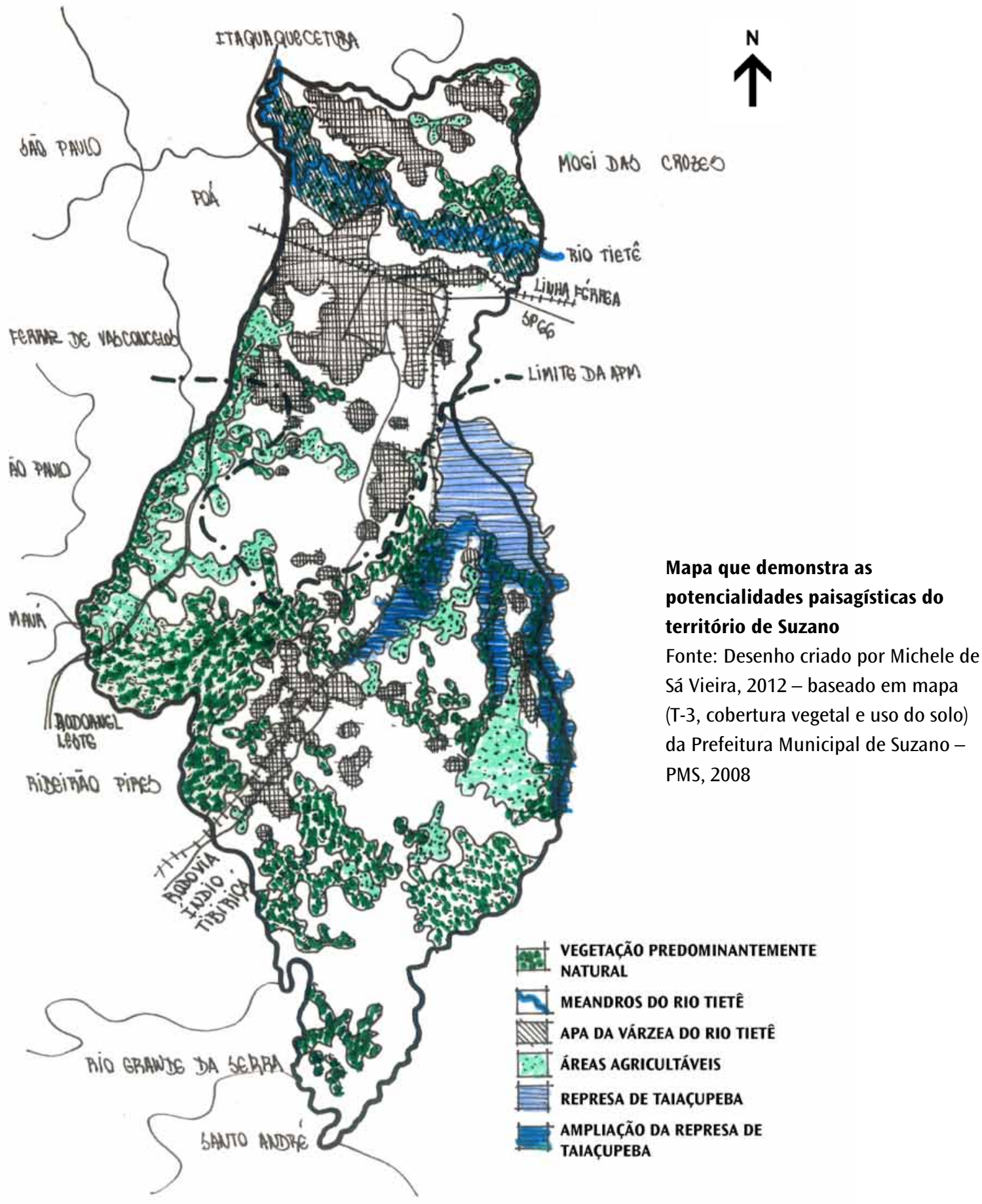


A Bacia Hidrográfica do Alto Tietê está sob a gestão do Comitê da Bacia Hidrográfica do Alto Tietê (CBH-AT), instalado em 1994, mas com funcionamento efetivo desde 1997. Esta unidade de gerenciamento é composta por 34 municípios da bacia, dos 39 territórios que compõem a Região Metropolitana de São Paulo (RMSP)!

A Sub-Bacia Hidrográfica do Alto Tietê Cabeceiras está sob a gestão do Subcomitê da Bacia Hidrográfica do Alto Tietê Cabeceiras, que "é um órgão colegiado, descentralizado, de caráter consultivo e deliberativo, vinculado ao Comitê da Bacia Hidrográfica do Alto Tietê, criado pela Lei n. 7663, de 30 de dezembro de 1991, com vistas a compatibilizar e integrar as ações em sua área de atuação, a qual abrange os municípios de Salesópolis, Biritiba Mirim, Mogi das Cruzes, Suzano, Poá, Ferraz de Vasconcelos, Itaquaquecetuba, Arujá, Guarulhos e São Paulo"2.

A região do Alto Tietê Cabeceiras possui importantes reservatórios de água, colaborando no abastecimento da Região Metropolitana de São Paulo, em função da sua alta produção com relação ao recurso hídrico.

O Sistema do Alto Tietê Cabeceiras (SPAT) é composto pelas represas Ponte Nova, Jundiai, Taiaçupeba, Biritiba-Mirim e Paraitinga, localizadas próximas às cabeceiras do rio Tietê, na região dos municípios de Salesópolis, Biritiba-Mirim, Mogi das Cruzes e Suzano. Os cinco reservatórios são interconectados por túneis, canais e sistemas de bombeamento. Na próxima imagem destacam-se os reservatórios de Taiaçupeba e Jundiai, situados respectivamente em Suzano e Mogi das Cruzes.
IO Comitê da Bacia Hidrográfica do Alto Tietê é composto de um Plenário, Diretoria com presidente, vice-presidente e secretaria-executiva, além de estruturar-se em cinco Subcomitês e Câmaras Técnicas.

${ }^{2}$ Subcomitê da Bacia Hidrográfica do Alto Tietê Cabeceiras (SBH - ATC) http://www.tietecabeceiras.com.br/ institucional/sobre-o-sub-comite. Acesso em: 16 de jan. 2012. 


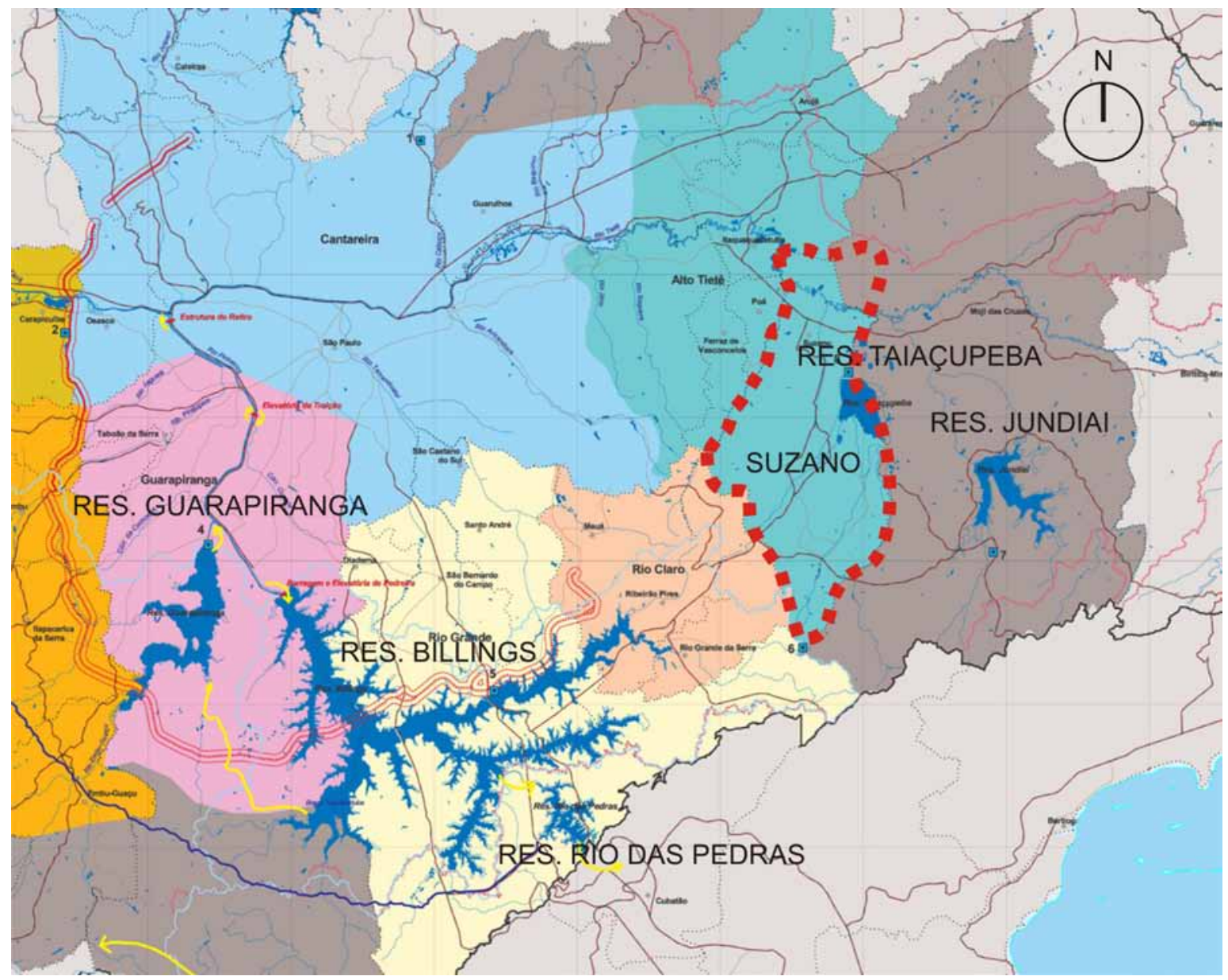

Sistema Produtor Alto Tietê (SPAT), ou simplesmente Sistema Alto Tietê, é um dos sistemas administrados pela SABESP destinados à captação, armazenamento e tratamento de água para a Grande São Paulo

Fonte: Secretaria do Estado do Meio Ambiente, 2000, sendo alterada pela Prefeitura de Suzano em 2008 
Contextualização territorial de Suzano

Seu território é um mosaico em transformação, composto por várzeas, áreas urbanizadas, agricultura, águas, fragmentos de mata nativa e as florestas de eucalipto. 


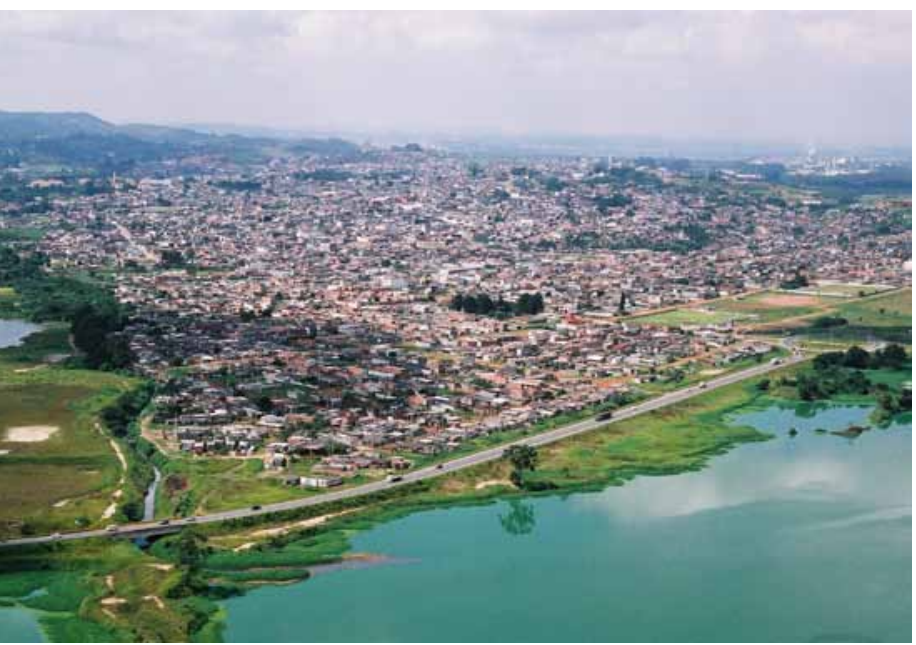

\section{Distrito de Boa Vista -}

\section{Loteamento Miguel Badra}

Fonte: Prefeitura Municipal

de Suzano, 2008

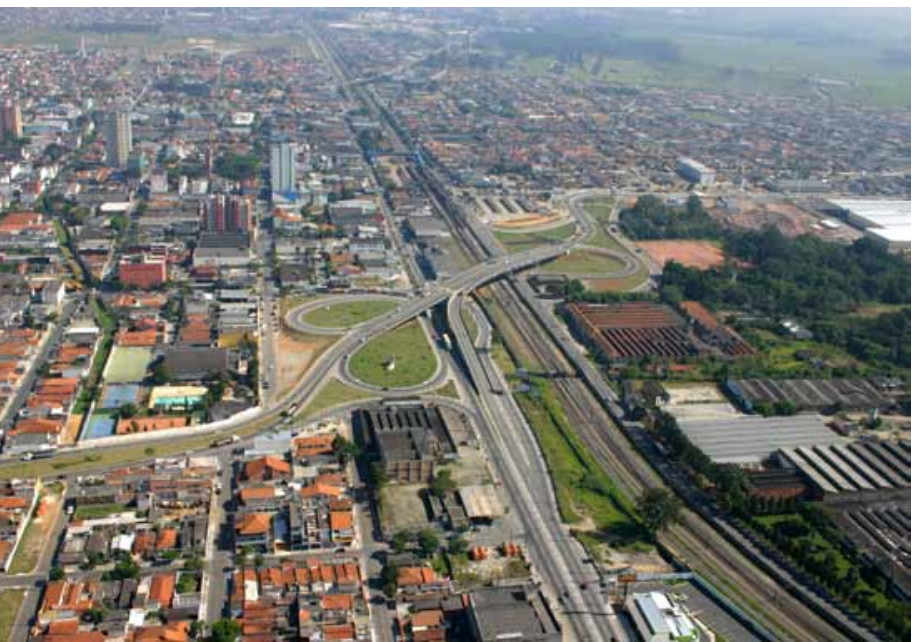

\section{Distrito Central - Loteamento Vila}

\section{Amorim}

Fonte: Prefeitura Municipal de

Suzano, 2008

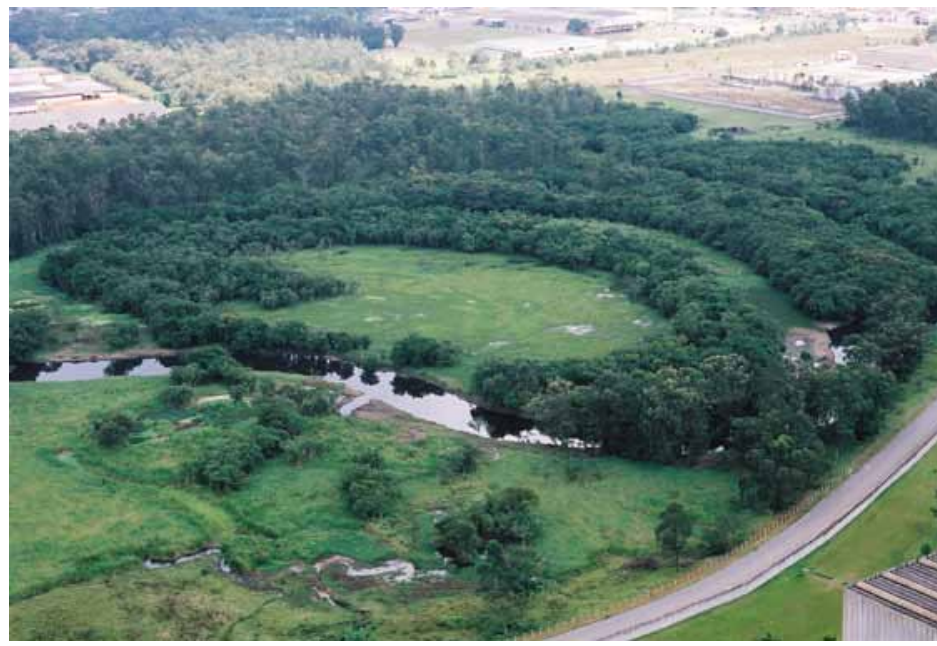

\section{Distrito de Boa Vista e Central -}

APA do rio Tietê

Fonte: Prefeitura Municipal de

Suzano, 2008

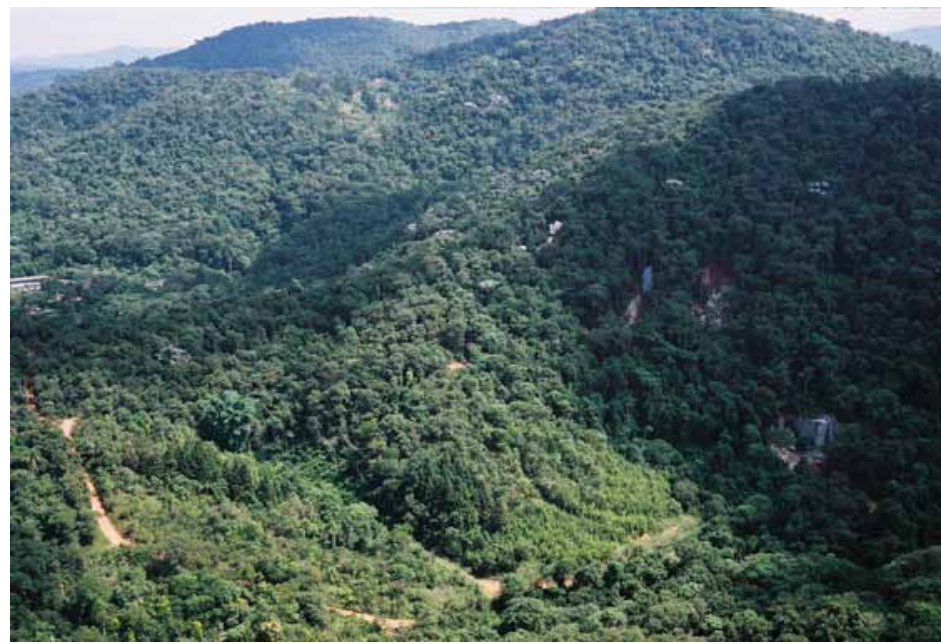

Distrito de Palmeiras - Matas

Nativas

Fonte: Prefeitura Municipal de

Suzano, 2008 


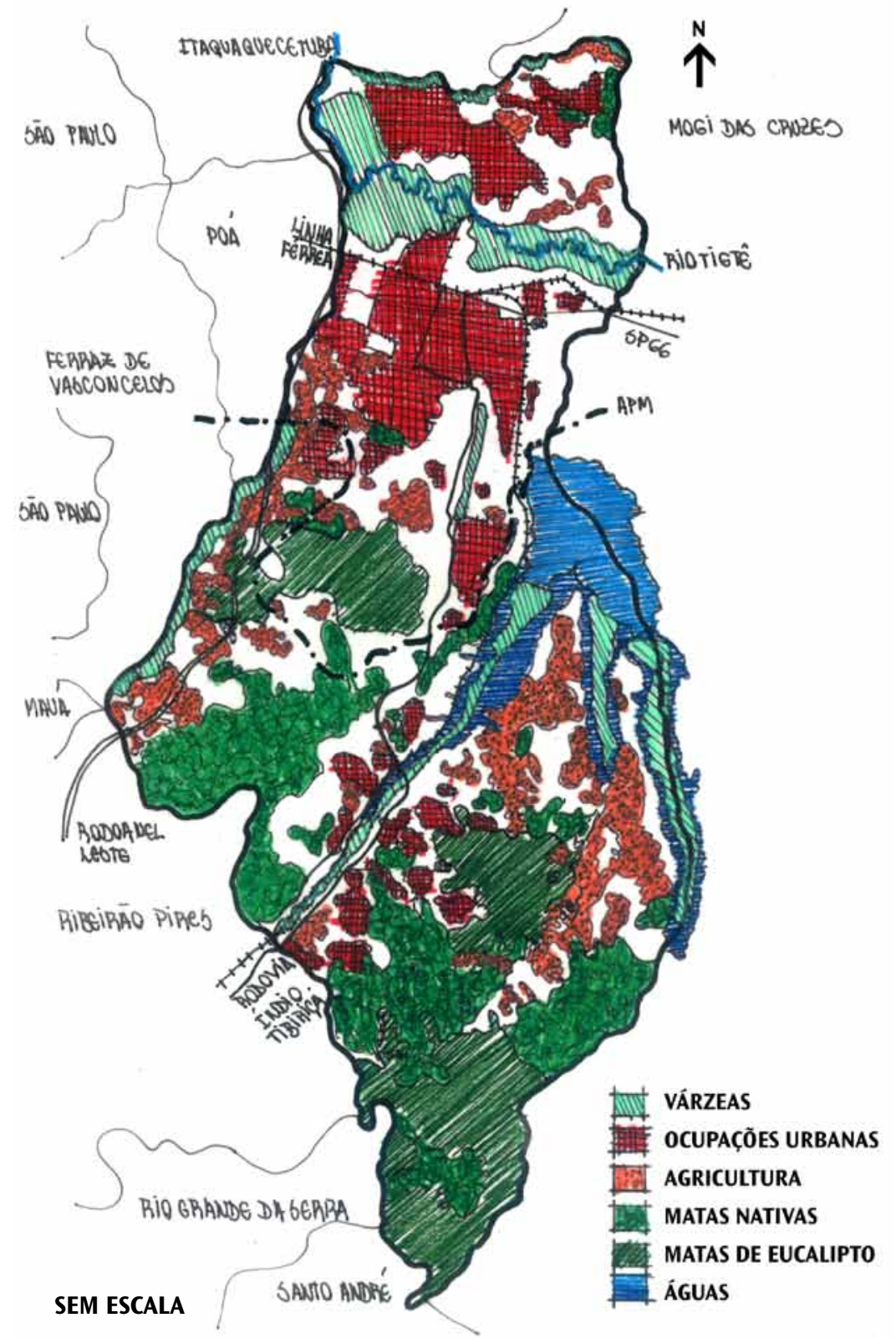

Assim, observa-se que Suzano possui urbanização compacta, tanto ao norte do território como ao centro, apresentando-se ao sul de forma fragmentada.

\section{Mapa do Mosaico de Suzano}

Fonte: Desenho criado por Michele de Sá Vieira, 2011 - baseado em mapa (T-3, cobertura vegetal e uso do solo) da Prefeitura Municipal de Suzano - PMS, 2008 
${ }^{3}$ Segundo o censo do IBGE - Instituto Brasileiro de Geografia e Estatística, 2010. < http://www.ibge. gov.br/cidadesat/painel/ painel. php?codmun $=355250>$. Acesso em: 06 de jun. 2011.
Verifica-se, ainda, que tais ocupações também se colocam de maneira conflituosa ao sul, em função de sua forte inserção em áreas densamente ocupadas por águas e matas, que na verdade deveriam ser preservadas.

0 municipio de 206,60 km² contava com uma população de 262.480 habitantes, o que resulta em uma densidade demográfica de 1.275,43 hab./ $\mathrm{km}^{2}$, sendo dividido em três distritos distintos: Boa Vista e Central, onde se concentram as maiores densidades populacionais da região; e Palmeiras, que se caracteriza por ocupações mais esparsas e encravadas na vegetação ${ }^{3}$. 


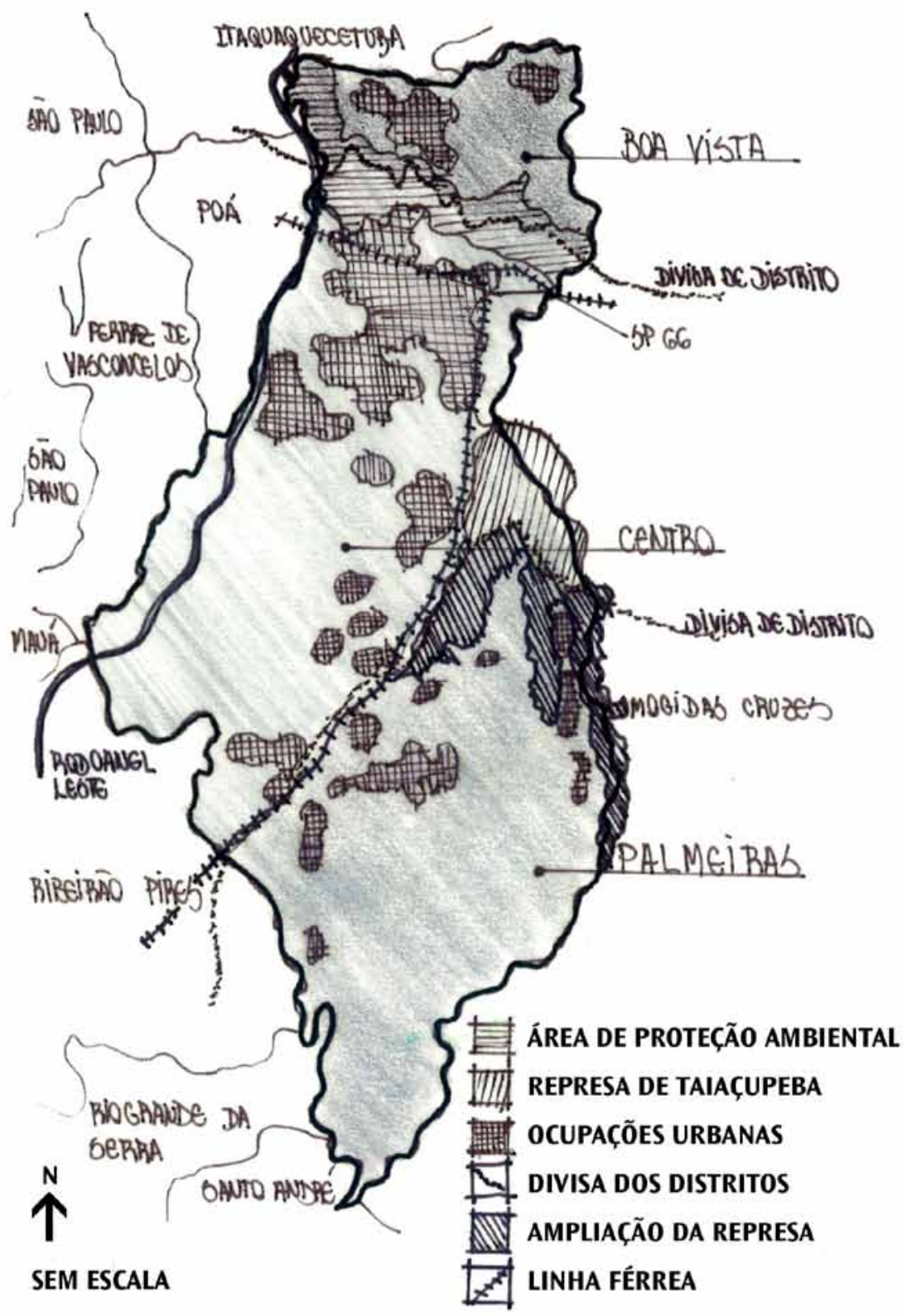

\section{Mapa com a divisão dos distritos de Suzano}

Fonte: Desenho criado por Michele de Sá Vieira, 2011 - baseado em mapa (T-1, áreas verdes, distritos e recursos hídricos) da Prefeitura Municipal de Suzano - PMS, 2008 
Além disso, como características gerais o município possui os seguintes dados:

\section{Distrito de Boa Vista}

${ }^{4}$ Segundo o censo do IBGE - Instituto Brasileiro de Geografia e Estatística, 2010. < http://www.ibge. gov.br/cidadesat/painel/ painel. php?codmun $=355250>$. Acesso em: 31 de jan. 2012.
Ao norte, no distrito de Boa Vista, localiza-se a área mais populosa do território, a qual contava com uma população de 82.811 habitantes, distribuída por 23,94 km², tendo como delimitação geográfica os municípios de Poá, Itaquaquecetuba e Mogi das Cruzes, enquanto dentro do próprio território se insere ao norte do rio Tietê, assentando-se sobre relevo plano na região junto à várzea do rio, enquanto o restante encontra-se em área com declividade acentuada 4 .

Os principais espaços livres deste distrito são o Parque Mirante do Tietê e parte do futuro Parque Várzeas do Tietê, que não possuem nenhum tratamento paisagístico. A principal caracteristica desta região é a baixa qualidade urbanística, por esta não possuir: espaços livres tratados, calçadas construidas, iluminação e saneamento ambiental em determinados locais, resultado este proveniente de décadas de falta de investimento por parte do Poder Público. Este, somente a partir de 2005, passou a voltar seus olhares e trabalho com mais ênfase para esta área, promovendo obras de infraestrutura como pavimentação, implementação de iluminação entre outras. 


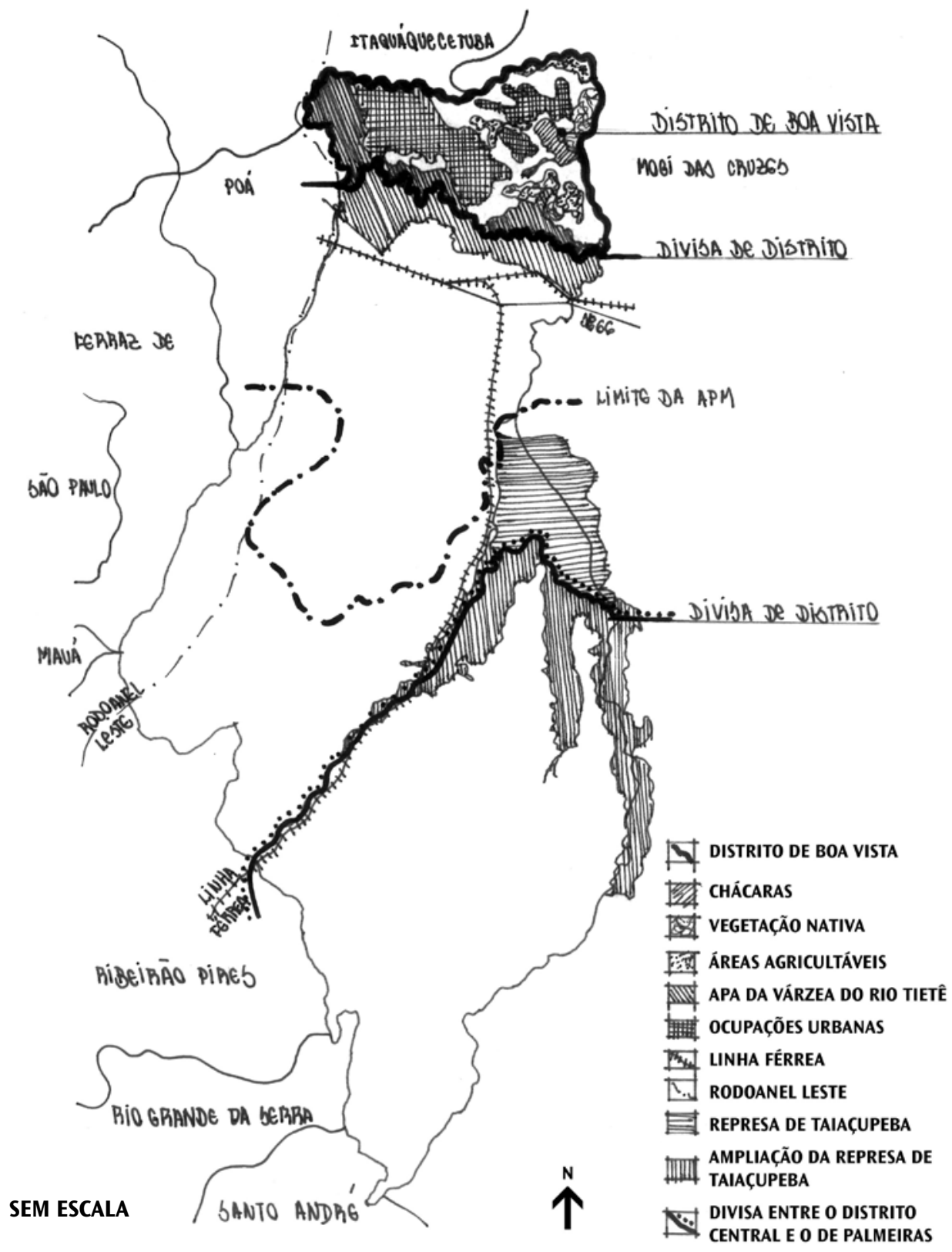

Mapa que demonstra a localização do distrito de Boa Vista

Fonte: Desenho criado por Michele de Sá Vieira, 2012 - baseado em mapa (T-1, áreas verdes, distritos e recursos hídricos) da Prefeitura Municipal de Suzano - PMS, 2008 


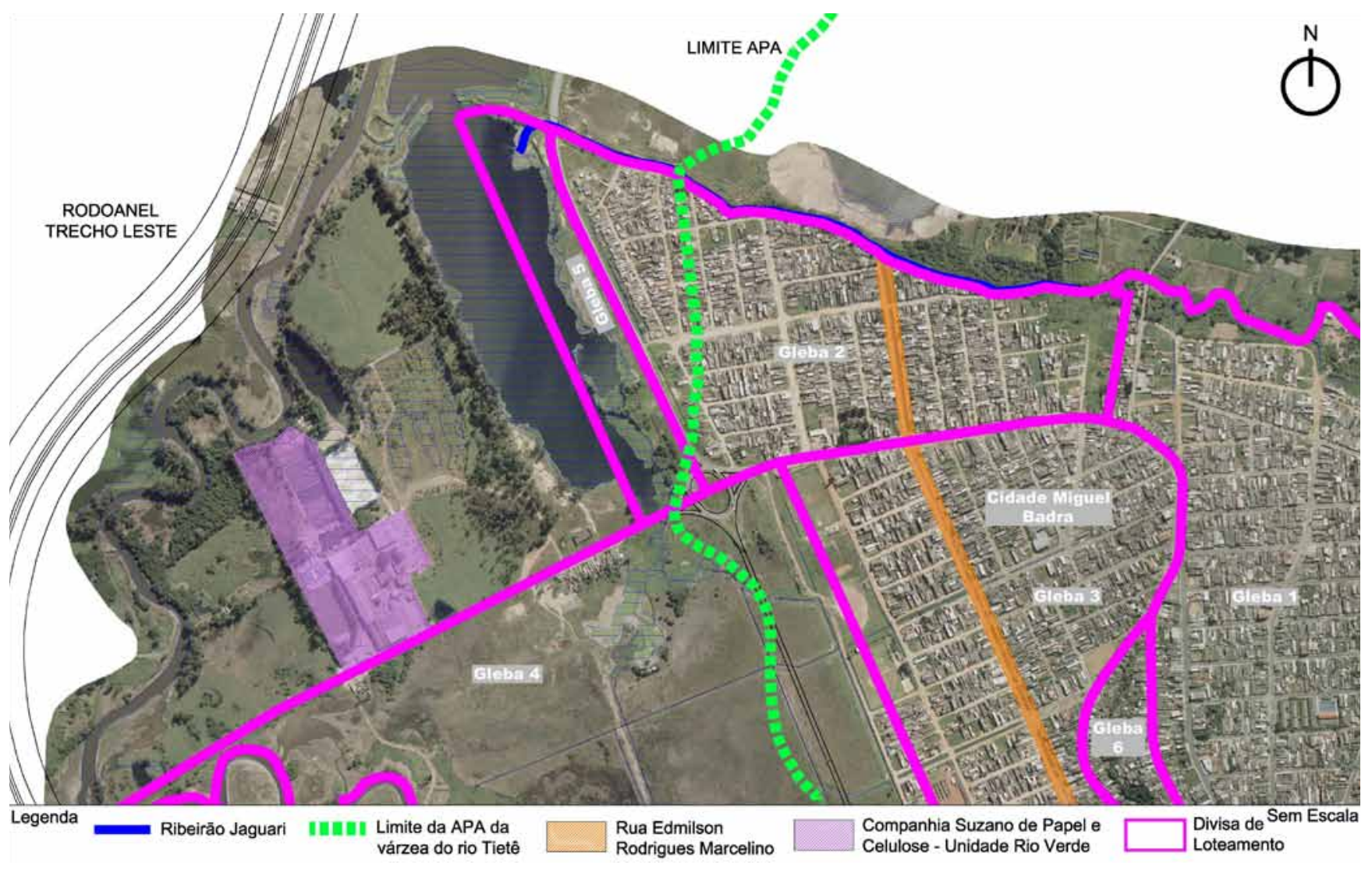

Suzano: Distrito de Boa Vista, loteamento Cidade Miguel Badra (Glebas 1, 2, 3, 4, 5 e 6), localizado na parte norte do território, sobre relevo plano. A urbanização é compacta, com o sistema viário linear, porém em alguns momentos ela é sinuosa. o loteamento é pavimentado, no entanto, as calçadas não possuem tratamento adequado, além de serem muito estreitas. Como aspecto positivo, possui ruas como a Edmilson Rodrigues Marcelino com boa extensão e canteiros centrais que possibilitam tratamento urbanístico, por exemplo, através da inserção de ciclovias. Outra característica importante deste loteamento, diz respeito ao fato dele estar próximo a APA do Tietê, sendo que dentro dela está uma das unidades da empresa Suzano Papel e Celulose Fonte: Prefeitura Municipal de Suzano, 2008 - imagem organizada por Michele de Sá Vieira e Sanderlei Fernandes Vilanova, 2012 


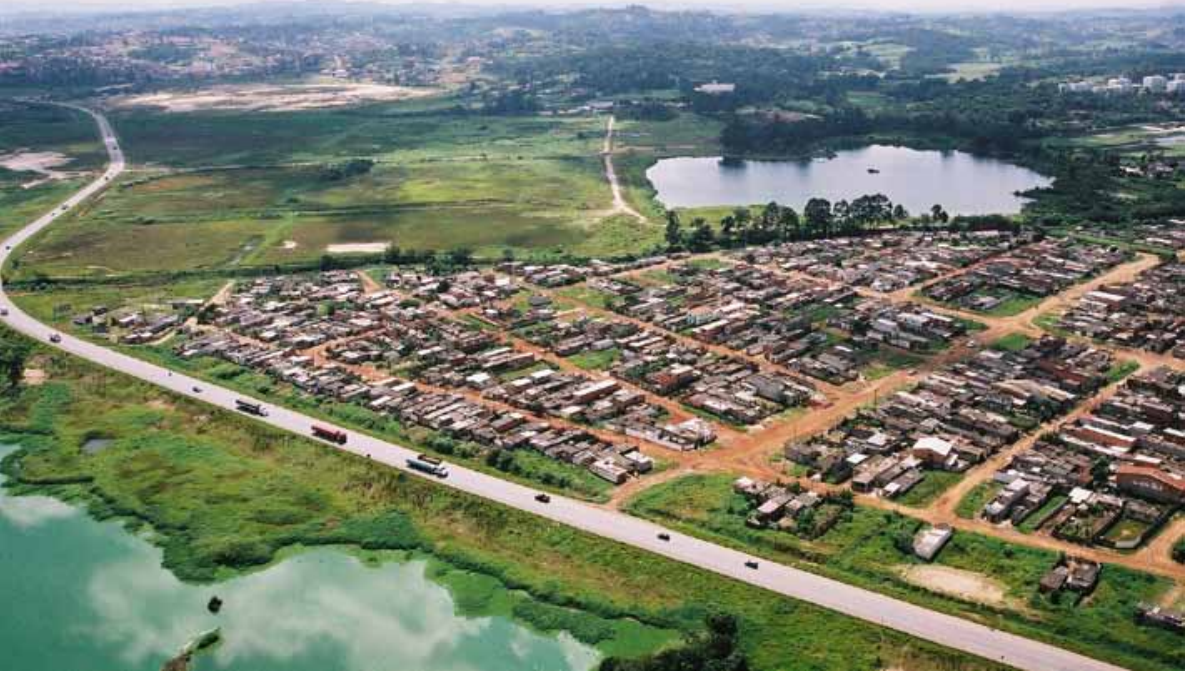

Suzano: Distrito de Boa Vista, loteamento Cidade Miguel Badra. Este loteamento, o qual possui topografia em parte plana, recebeu diversos investimentos com relação à pavimentação, além de equipamentos voltados à saúde $e$ à educação, no entanto, o sistema de espaços livres públicos é precário por não possuir tratamento urbanístico e paisagístico Fonte: Prefeitura Municipal de Suzano, 2008

Suzano: Distrito de Boa Vista, loteamento Cidade Miguel Badra. A Rua Edmilson Rodrigues Marcelino possui grandes canteiros centrais, assentados sobre sistema viário pavimentado. Embora a avenida guarde esta potencialidade urbanística, em 2012, eles são utilizados de maneira inadequada ao servirem como estacionamento. As calçadas não possuem tratamento urbanístico adequado, em função da ausência de revestimento e dimensão suficientes, que sejam capazes de resguardar as necessidades dos pedestres, além de serem também usadas como estacionamento. Em alguns espaços deste loteamento, nota-se até mesmo a ausência de pavimentação

Fonte: Arquivo Michele de Sá Vieira, 2011
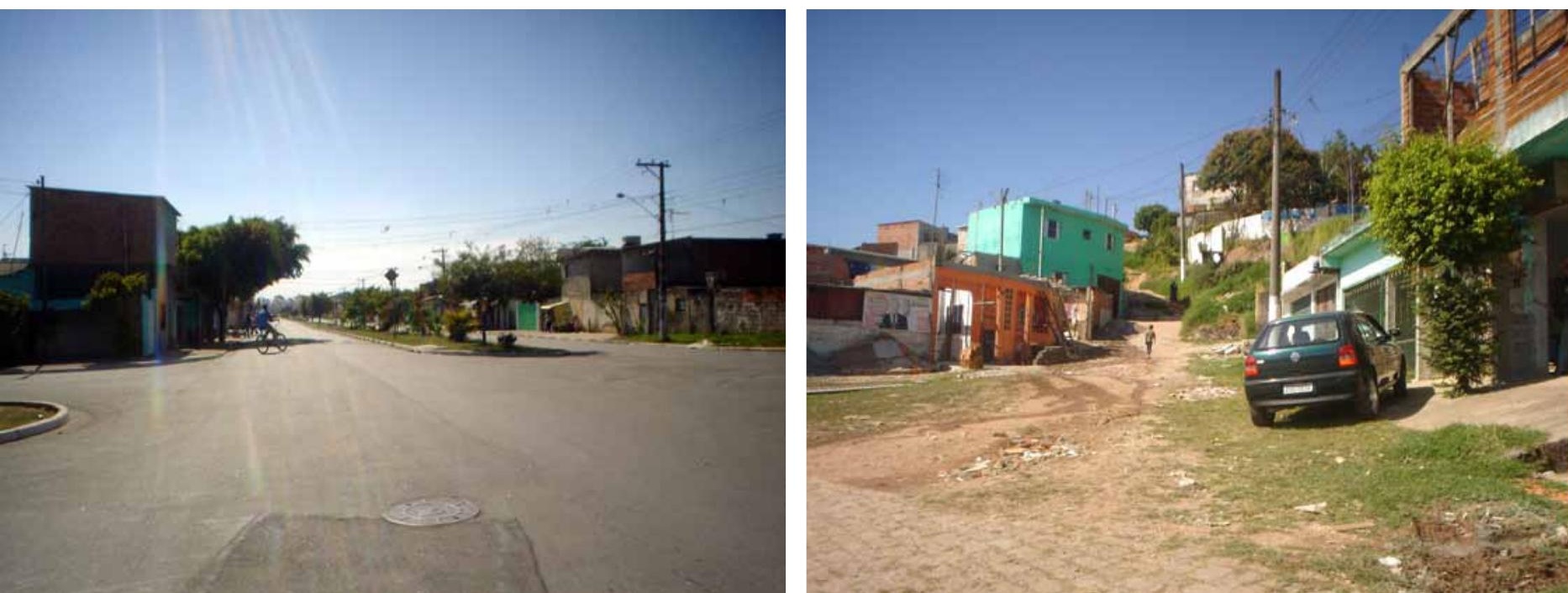


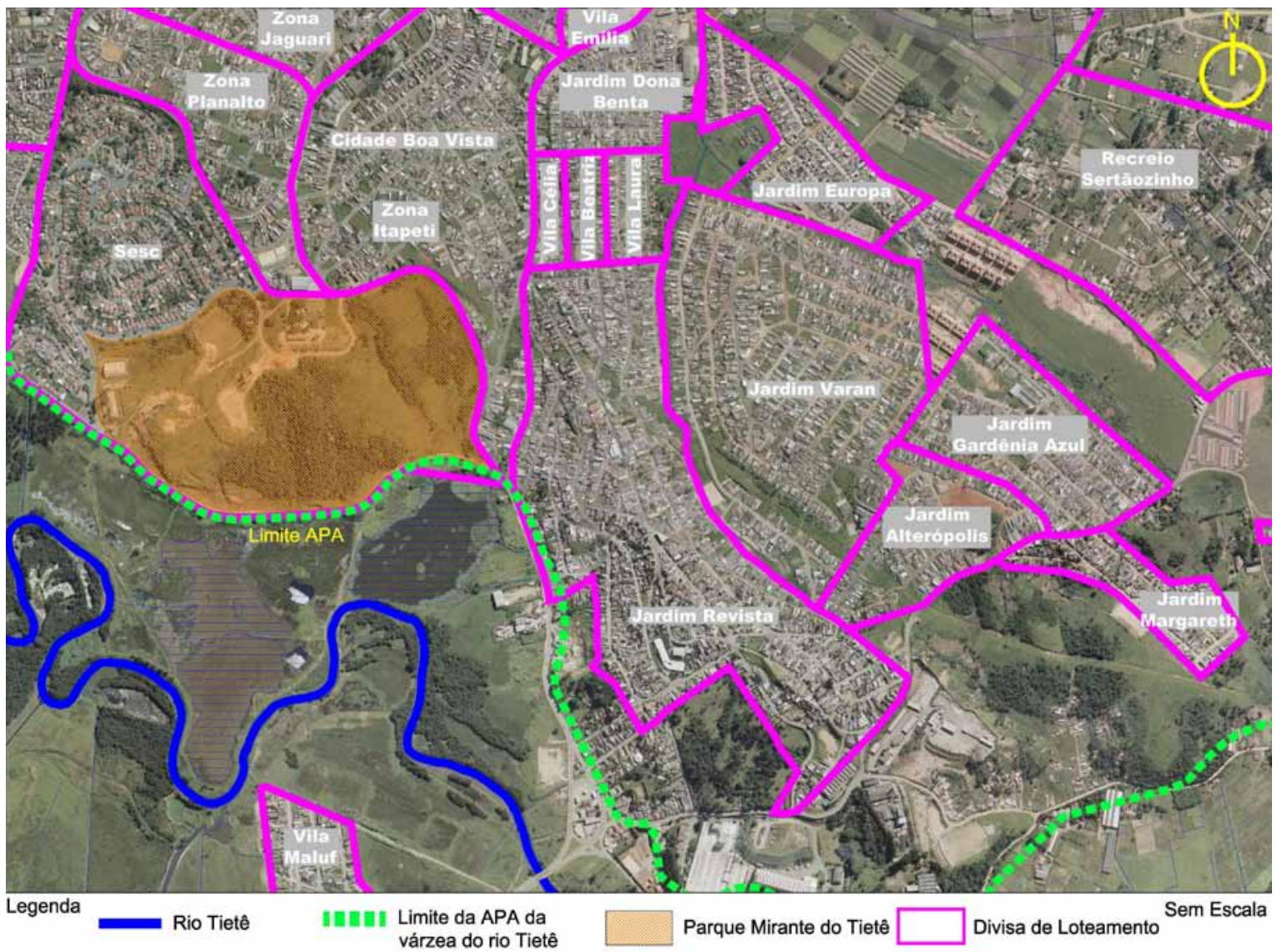

Suzano: Distrito de Boa Vista. Situados na parte norte do município, os loteamentos do SESC, Planalto, Itapeti, Jardim Revista, entre outros, localizam-se em um dos espaços de maior altitude do território sobre relevo inclinado. Em função disso, a malha viária é bastante sinuosa. No que se refere aos espaços livres dessa região, eles são muitos, porém nem todos se encontram tratados. Como maior potencialidade, tem-se o Parque Mirante do Tietê, fazendo fronteira com o rio Tietê (em 2012 ele não está de fato instalado)

Fonte: Prefeitura Municipal de Suzano, 2008 - imagem organizada por Michele de Sá Vieira e Sanderlei Fernandes Vilanova, 2012 

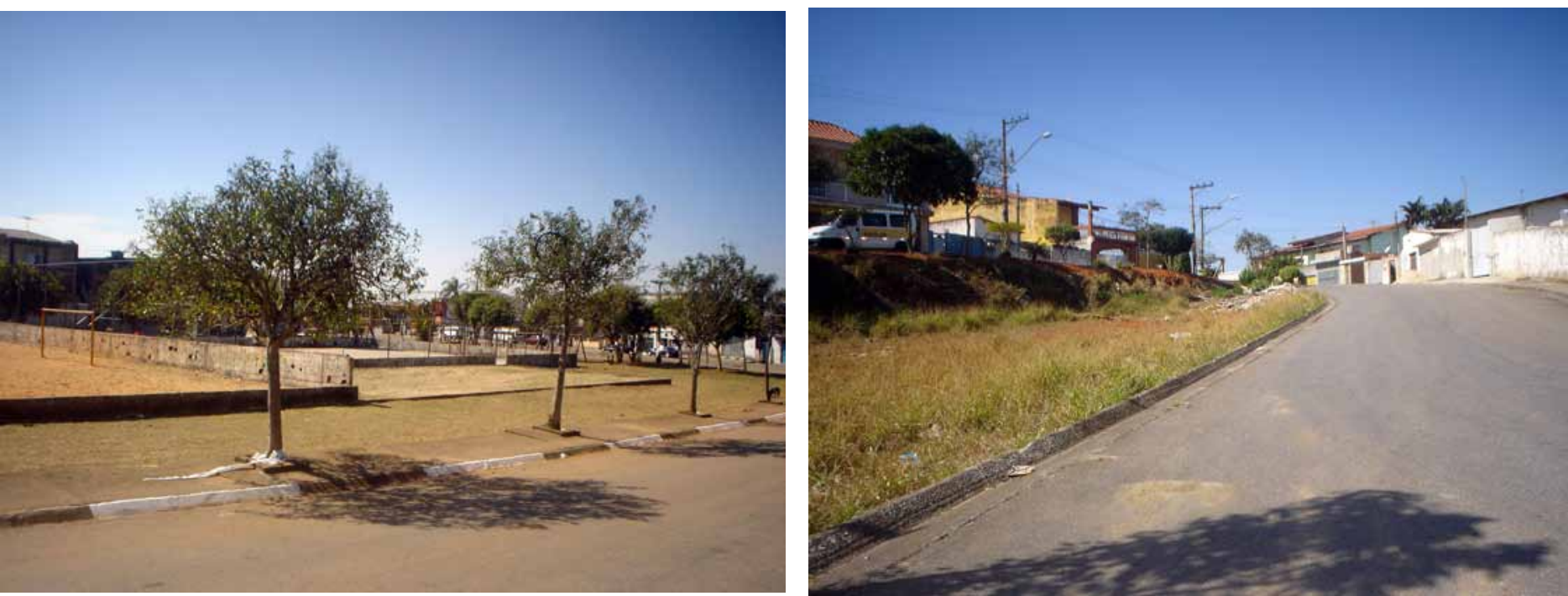

Suzano: Distrito de Boa Vista, loteamento Cidade Boa Vista - Praça 21 de abril e Avenida Boa Vista. Assim como no loteamento do Miguel Badra, o loteamento Cidade Boa Vista contém muitos canteiros centrais de boa dimensão para serem tratados dentro dos aspectos urbanísticos e paisagísticos. Além disso, possui inúmeros espaços livres, destinados à recreação, tais como praças, que possuem quadras e brinquedos

Fonte: Arquivo Michele de Sá Vieira, 2011

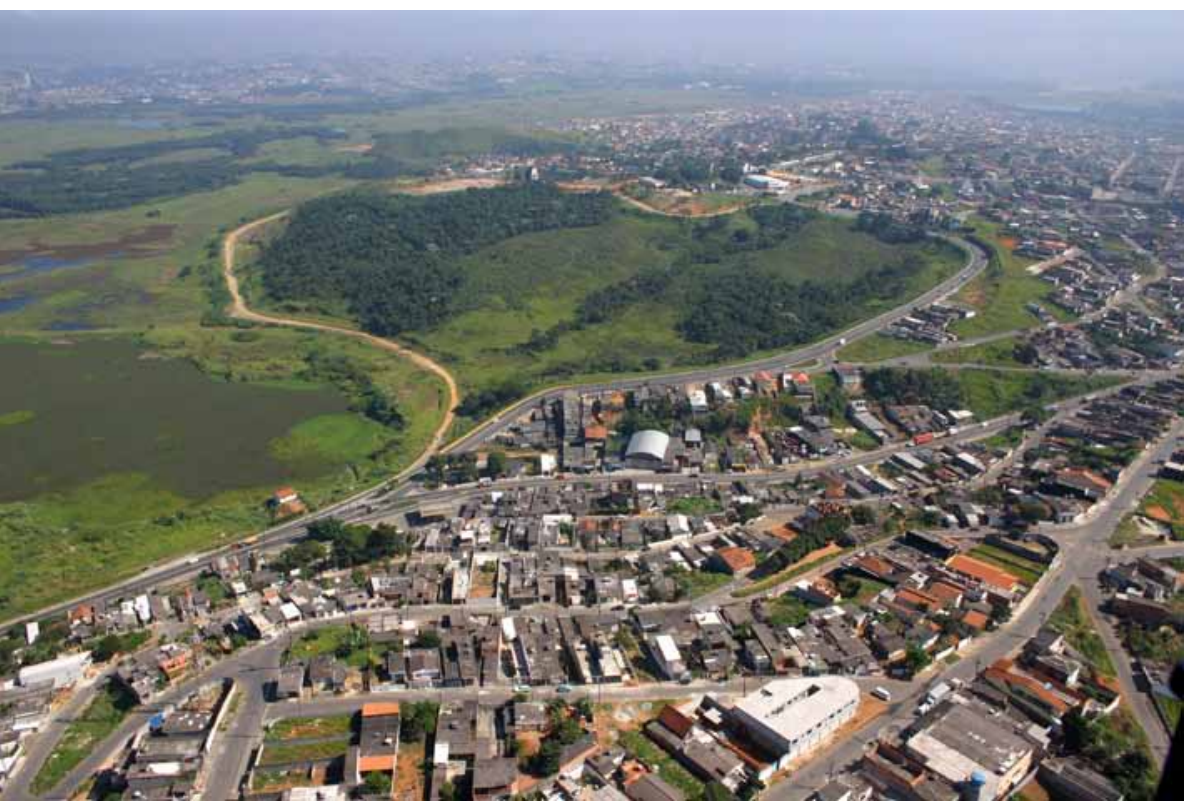

Suzano: Distrito de Boa Vista, loteamentos Jardim Revista, Itapeti, Planalto, SESC, entre outros. Estes loteamentos, que estão localizados em uma das cotas mais altas da cidade, possuem topografia acidentada e são densamente ocupados, além disso contêm espaços livres recobertos por fragmentos de mata bastante íntegros

Fonte: Prefeitura Municipal de Suzano, 2008 


\section{Parque Mirante do Tietê}

0 Parque Mirante do Tietê, no entanto, ainda não contém de fato (em 2012) as funções de um parque, localiza-se no loteamento do SESC, com uma área de aproximadamente $350.000 \mathrm{~m}^{2}$, fazendo fronteira com a APA do Tietê, futuro Parque Várzeas do Tietê, é considerado o mais importante fragmento não urbanizado do município, pelas suas dimensões e caracteristicas físicas inseridas junto a um tecido urbano consolidado.

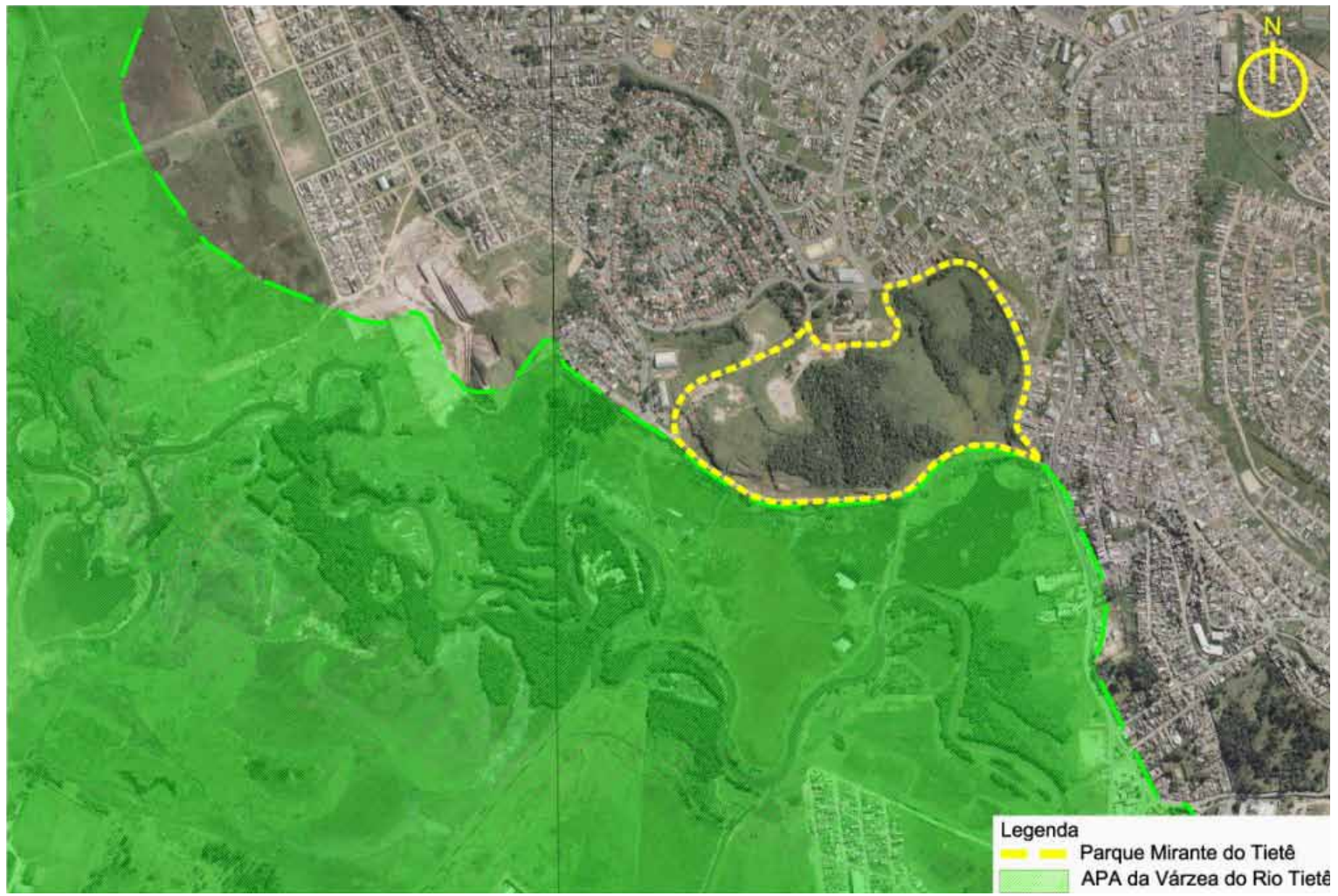

Suzano: Distrito de Boa Vista. Parque Mirante do Tietê. Esta área caracteriza-se por estar parcialmente degradada, guardando ainda três grandes manchas de vegetação nativa - cada uma com aproximadamente $93.000 \mathrm{~m}^{2}, 13.000$ $\mathrm{m}^{2}$ e $16.000 \mathrm{~m}^{2}$, perfazendo um total de $122.000 \mathrm{~m}^{2}$, o que nos mostra, portanto, que $35 \%$ da área ainda se encontra preservada

Fonte: Prefeitura Municipal de Suzano, 2008 - imagem organizada por Michele de Sá Vieira e Sanderlei Fernandes Vilanova, 2012 

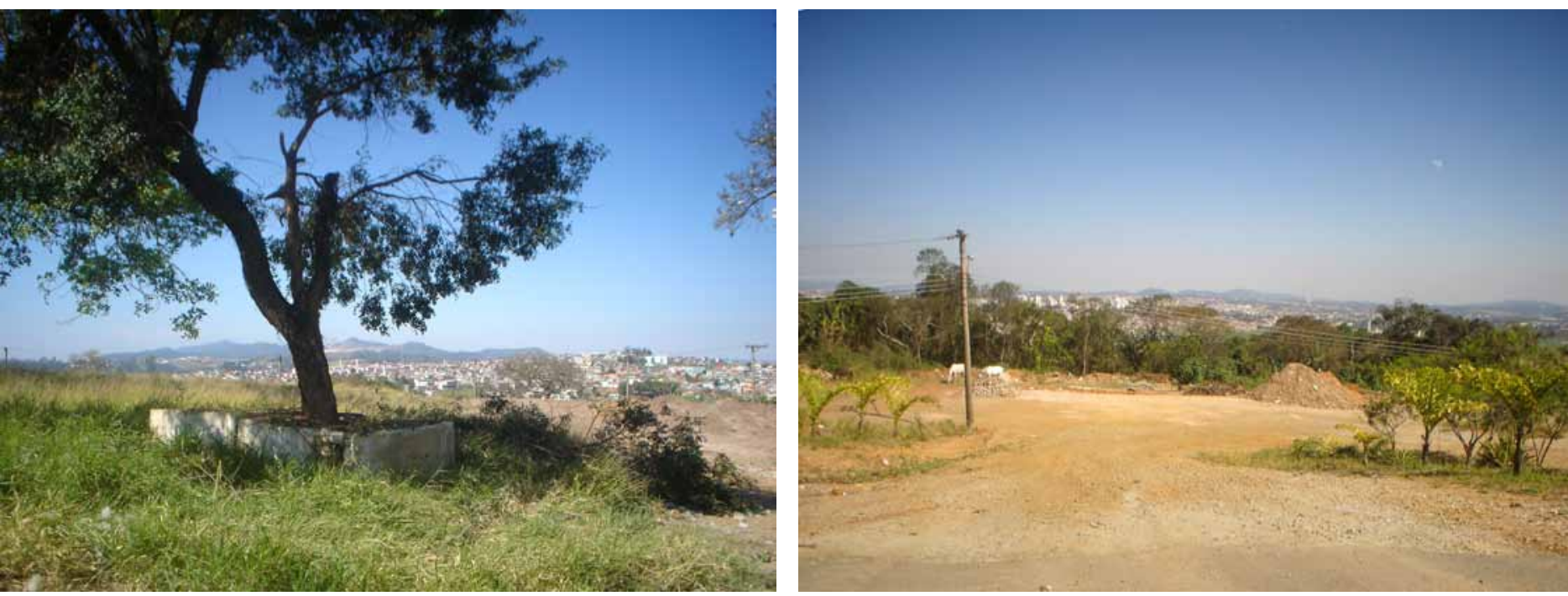

Suzano: Distrito de Boa Vista, loteamento do SESC - área do Parque Mirante do Tietê. Apesar da aparente degradação do local, em função do depósito de resíduos da construção civil, como mostra a foto o espaço possui dupla importância por apresentar três grandes fragmentos de Mata Atlântica e por ter potencialmente extensas áreas a serem destinadas ao lazer

Fonte: Arquivo Michele de Sá Vieira, 2011

\section{APA da Várzea do rio Tietê}

Uma das principais características do distrito de Boa Vista trata-se do fato deste abrigar parte da APA da várzea do rio Tietê:

Dessa forma, ao norte, dentro do distrito de Boa Vista, a APA:

- é limitada pelo loteamento do SESC, onde encontra-se o Parque Mirante do Tietê;

- contém parte das Glebas 4, 5 e 7, as quais compõem o loteamento Cidade Miguel Badra;

- é vizinha dos loteamentos Cidade Miguel Badra (Gleba 3), Jardim Revista, Jardim Alterópolis, Jardim Gardênia Azul, Jardim Margareth, Jardim Carla e Meu Sossego.

Já, ao sul, dentro do distrito Central a APA:

- $\quad$ encontra-se limitada pelo loteamento Vila Maria de Maggi;

- contém parte dos loteamentos Parque Maria Helena e Vila Maluf;

- está lindeira aos loteamentos Vila Amorim, Jardim Belém, Jardim Miriam, Jardim Bela Vista e Jardim Leymar. 


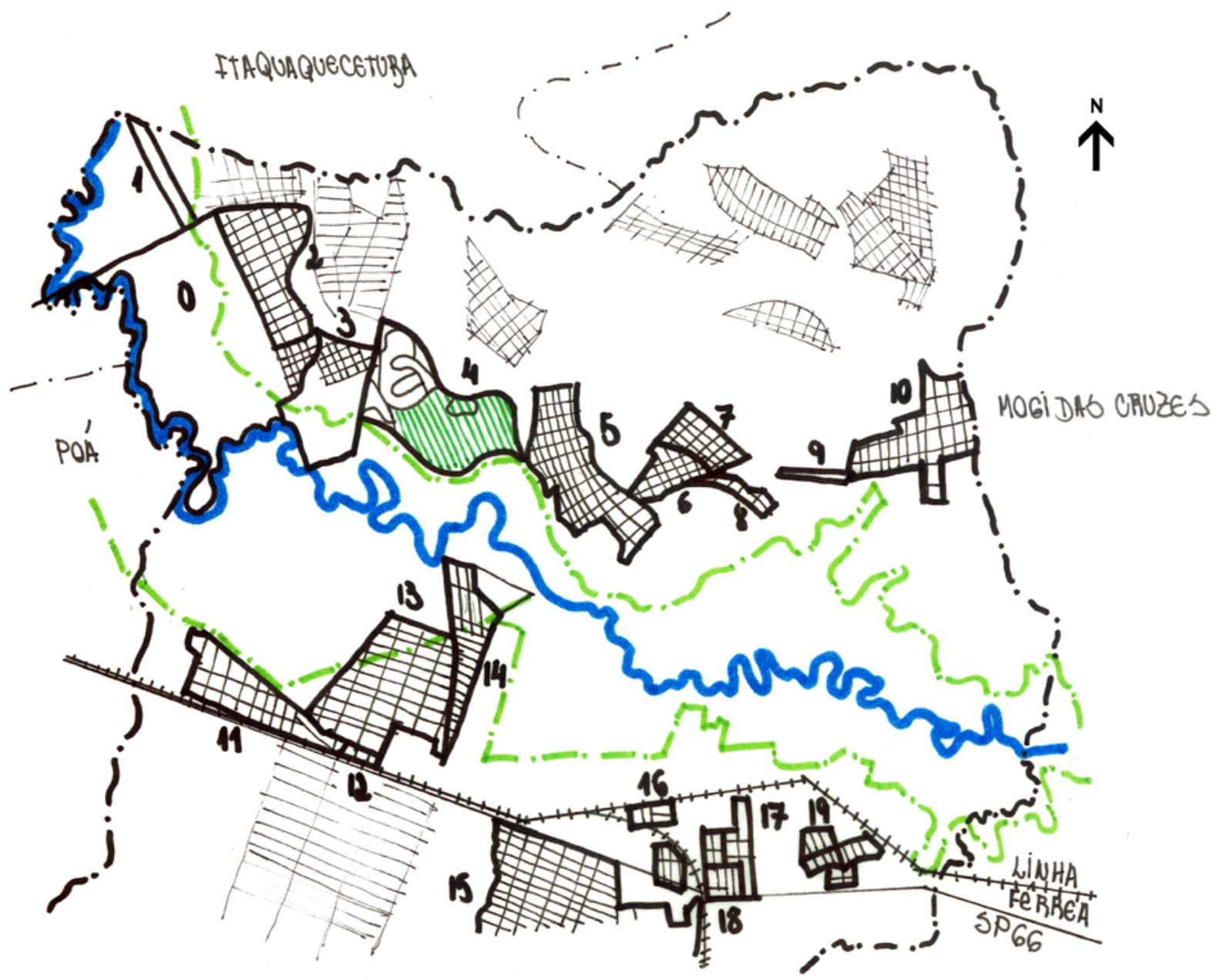

D. Divisa do municípIo de SUZANo

¿ LIMITE dA APA DA VÁrzeA do tIEtÊ

RIO TIETÊ

\section{Z LIMITE DOS LOTEAMENTOS}

\section{PARQUE MIRANTE DO TIETÊ}

\author{
0 - Cidade Miguel Badra (Gleba 4) \\ 1 - Cidade Miguel Badra (Gleba 5) \\ 2 - Cidade Miguel Badra (Gleba 3) \\ 3 - Cidade Miguel Badra (Gleba 7) \\ 4 - SESC \\ 5 - Jardim Revista \\ 6 - Jardim Alterópolis \\ 7 - Jardim Gardênia Azul \\ 8 - Jardim Margareth \\ 9 - Jardim Carla
}

10 - Meu Sossego

11 - Vila Maria de Maggi

12 - Jardim Maria Helenice

13 - Parque Maria Helena

14 - Vila Maluf

15 - Vila Amorim

16 - Jardim Belém

17 - Jardim Miriam

18 - Jardim Bela Vista

19 - Jardim Leymar

Mapa que demonstra a localização da Área de Proteção Ambiental - APA da várzea do rio Tietê, bem como dos loteamentos que estão próximos aos seus limites

Fonte: Desenho criado por Michele de Sá Vieira, 2012 - baseado em mapa T-5 do plano diretor de macrodrenagem, da Prefeitura Municipal de Suzano - PMS, 2008 
Ao longo dos anos, esta área tem sofrido variadas pressões antrópicas como o descarte de resíduos, assoreamento do leito do rio e especulação imobiliária e, apesar das situações adversas, a várzea do rio Tietê possui fragmentos de Mata Ciliar e planícies de alagamentos originais preservadas ao longo de um percurso com 13.500 m de extensão, com zonas de vida silvestre, tendo seus meandros intactos, diferentemente de muitos municípios que compõem a várzea do Tietê.
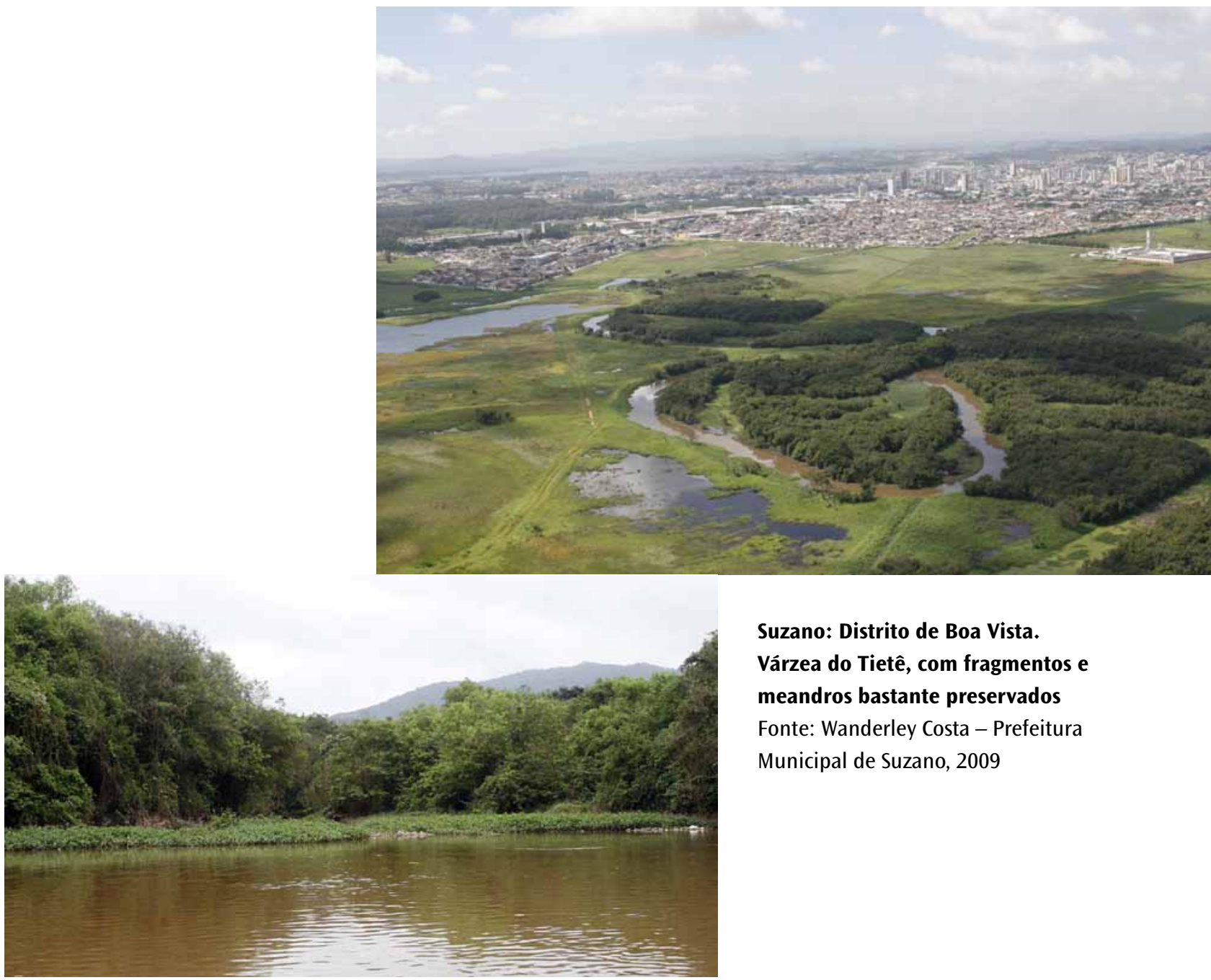

Suzano: Distrito de Boa Vista. Várzea do Tietê, com fragmentos e meandros bastante preservados Fonte: Wanderley Costa - Prefeitura Municipal de Suzano, 2009 
${ }^{5}$ Em 1982 foi inaugurado, pelo Governo do Estado de São Paulo, o Parque Ecológico do Tietê, o qual não foi implantado em sua totalidade. Somente dois trechos foram implantados: o de São Paulo (Barragem da Penha) até o município de GuaruIhos e de Tamboré em Barueri
Por reconhecer a potencialidade vinculada à várzea do Tietê, a principal ação pública de caráter nitidamente metropolitano prevista para os próximos anos, em relação a essa área privilegiada, trata-se da implantação do projeto Parque Várzeas do Tietê para que este espaço se volte para a população, passando a fazer parte do seu cotidiano, no que se refere às atividades vinculadas à educação ambiental, ao esporte e ao lazer.

Tendo o projeto do Parque Ecológico do Tietê sido feito em 1976, com implantação parcial datada de 1980, o que se verifica é que esta ação pública estadual, que inicialmente transformou a várzea em Área de Proteção Ambiental (APA), em 2010, a transforma em Parque Várzeas do Tietê 5 .

A retomada do projeto pelo Governo do Estado de São Paulo, através do Departamento de Águas e Energia Elétrica (DAEE), se apresentou, em 2009, como uma oportuna medida no que se refere ao resgate ambiental deste espaço, podendo ser entendida claramente como uma iniciativa interligada às eleições presidenciais de 2010, uma vez que o ex-governador do Estado de São Paulo foi candidato à presidência da república.

De qualquer forma, a proposta é uma oportunidade de garantir a preservação de amplas porções da várzea do Tietê como atenuante das enchentes que periodicamente castigam a metrópole, causando perdas de toda ordem. 
Proposta de localização para o futuro Parque Várzeas do Tietê - Trecho Salesópolis a São Paulo

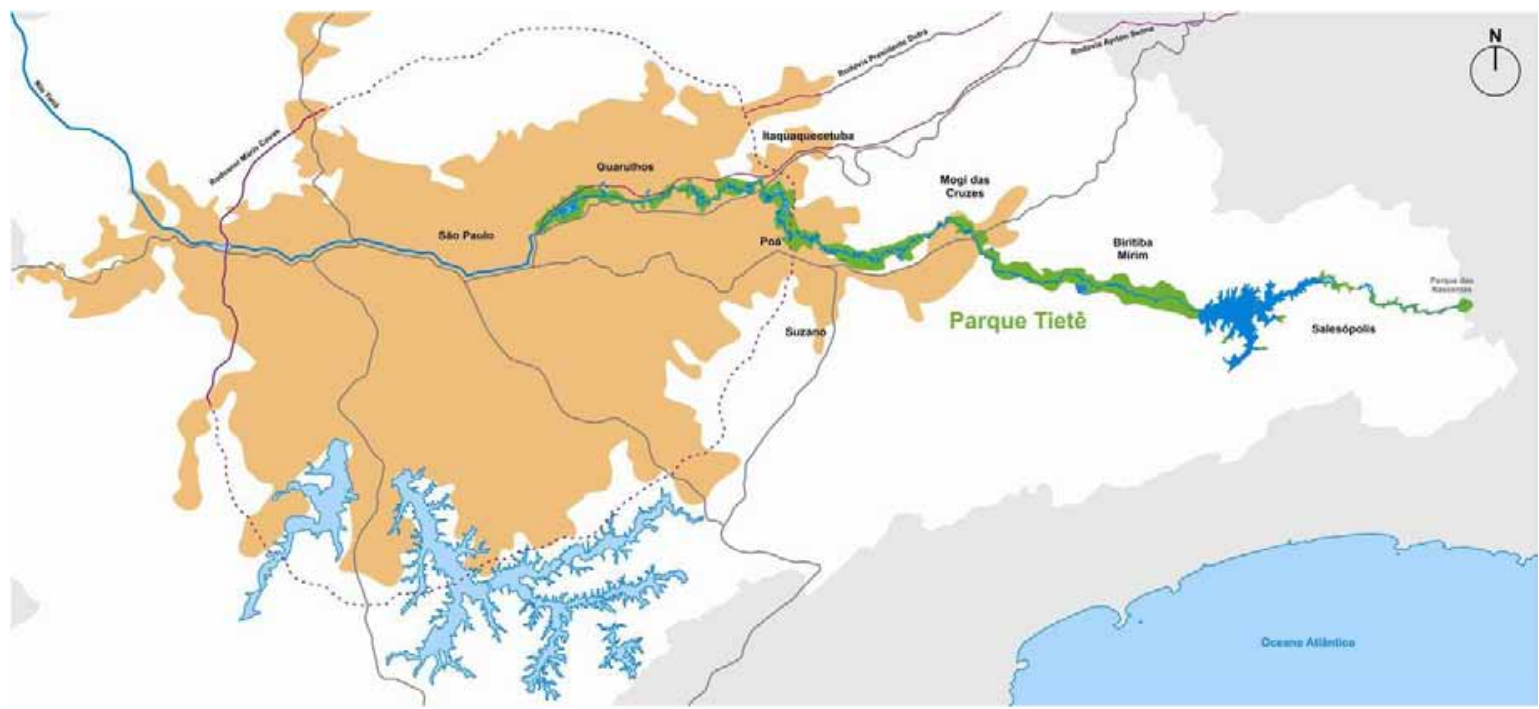

O Parque Várzeas do Tietê, idealizado pelo arquiteto Ruy Ohtake, em 1976, contempla todo o Alto Tietê

Cabeceiras. Trata-se de um equipamento de porte regional, envolvendo 10 municípios com o objetivo de preservar as várzeas do rio Tietê

Fonte: Escritório Ruy Ohtake, 2008

Proposta de localização para o Parque Várzeas do Tietê - Trecho Mogi das Cruzes a São Paulo

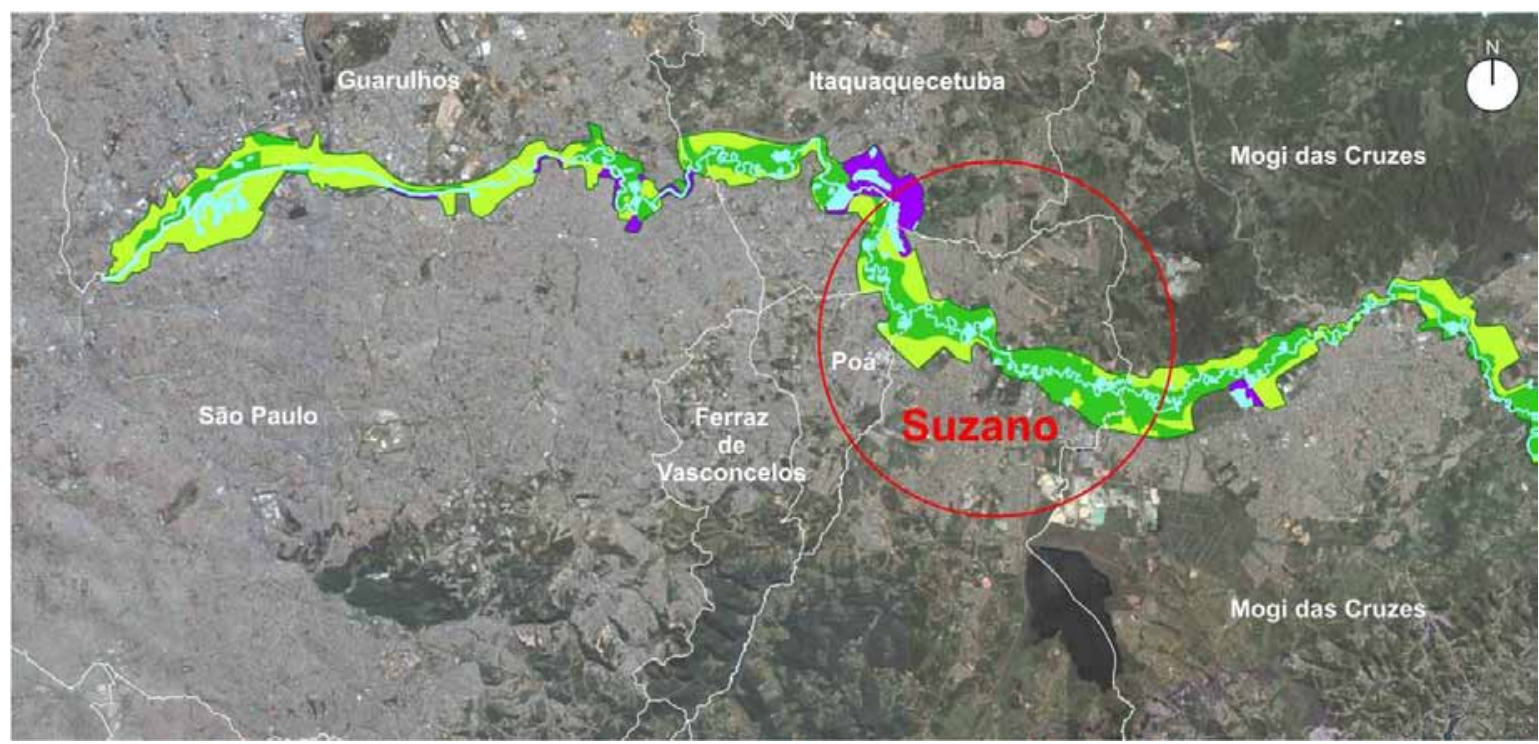

0 projeto propõe, dessa forma, uma intervenção urbano-ambiental que contempla desde o município de Salesópolis até a Barragem da Penha, com extensão de 50 km e condições para abranger mais de 1.500 hectares de área pública, surgindo como elemento organizador da paisagem e do crescimento urbano Fonte: Escritório Ruy Ohtake, 2008 
Proposta para o Parque Várzeas do Tietê em Suzano

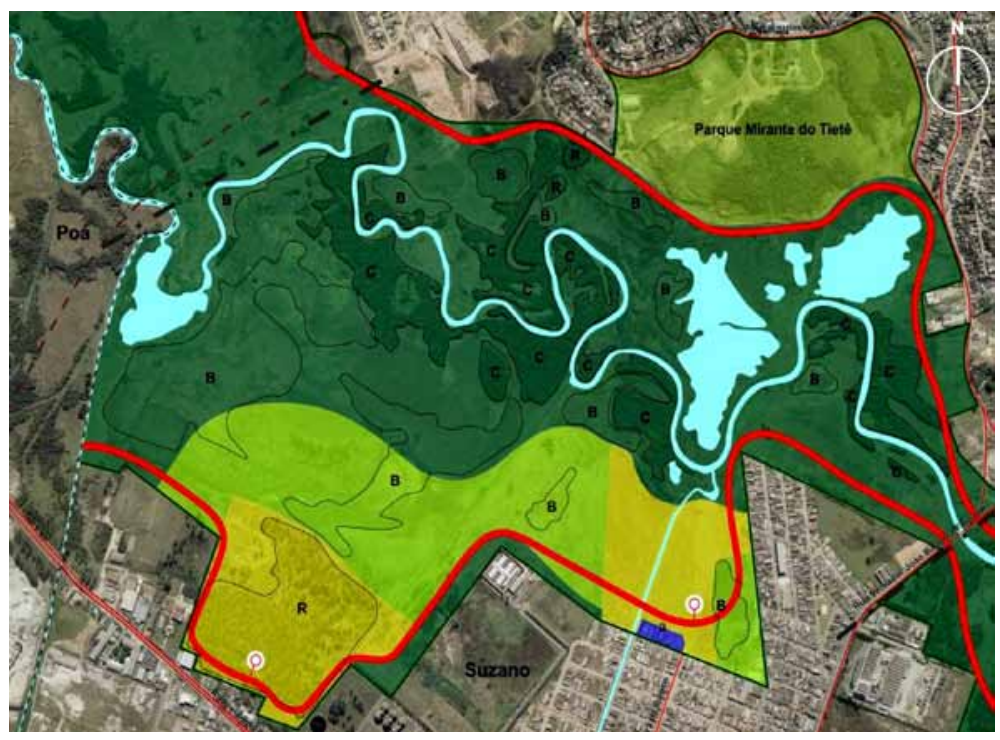

Entende-se que, em função do município apresentar carências no que se refere às áreas de esporte, lazer e recreação, a várzea poderá ser incorporada ao sistema de espaços livres públicos do território, a qual irá propiciar uma nova configuração para a paisagem no que se refere às suas atividades sociais, através da implementação de equipamentos de lazer, cultura, recreação e contemplação, mas também em função desta ação ter a capacidade de possibilitar futuras conexões ecológicas e ambientais com outros elementos do município, como o Parque Mirante do Tietê, que está ao seu lado.

No entanto, apesar de apresentar todo este potencial metropolitano, é importante analisar que o projeto, por ser de alçada estadual vai depender de políticas futuras (2012 em diante) a serem trabalhadas de forma compartilhada entre o governo municipal e o estadual, no que se refere a sua implementação e manutenção.
O espaço após a implantação do projeto terá características de um parque urbano onde a população poderá usufruir desta faixa aberta que integra os equipamentos de uso social com a vegetação e a água. 0 parque será contemplado não somente com equipamentos de lazer, mas também com projetos de revegetação arbórea, capaz de restabelecer o ecossistema, hoje parcialmente degradado por ações antrópicas

Fonte: Escritório Ruy Ohtake, 2008 


\section{Distrito Central}

${ }^{6}$ Segundo o censo do IBGE - Instituto Brasileiro de Geografia e Estatística, 2010. < http://www.ibge. gov.br/cidadesat/painel/ painel. php?codmun $=355250>$. Acesso em: 31 de jan. 2012.
DISTRITO CENTRAL

ESTAÇÃO DE TRATAMENTO DE ESGOTO ESTAÇ̃̃o de TRATAMENTO de ÁGUA NÚCLEO DO BARUEL APA DA VÁRZEA DO RIO TIETÊ OCUPAÇ̃̃ES URBANAS áreas AGRICULtáveis CULTIVO DE EUCALIPTO FRAGMENTOS FLORESTAIS DE MATA NATIVA

RESERVA PARTICULAR DE MIRAPORANGA REPRESA DE TAIAÇUPEBA

AMPLIAÇÃO DA REPRESA DE TAIAÇUPEBA

Mapa que demonstra a localização do distrito Central

Fonte: Desenho criado por Michele de Sá Vieira, 2012 - baseado em mapas ( $\mathrm{T}-1$, áreas verdes, distritos e recursos hídricos e T-6, turismo) da Prefeitura Municipal de Suzano - PMS, 2008
0 Distrito Central, que possui a segunda área mais populosa do território, contava com uma população de 155.804 habitantes, distribuida por 107,84 km², tendo como delimitação geográfica os municípios de Poá, Ferraz de Vasconcelos, Mauá, Ribeirão Pires e Mogi das Cruzes, enquanto dentro do próprio município ao norte é delimitado pelo rio Tietê, ao sul seus limites estão junto à Represa de Taiaçupeba e próximos à linha férrea operada pela MRS Logistica, assentando-se principalmente sobre relevo considerado plano6.

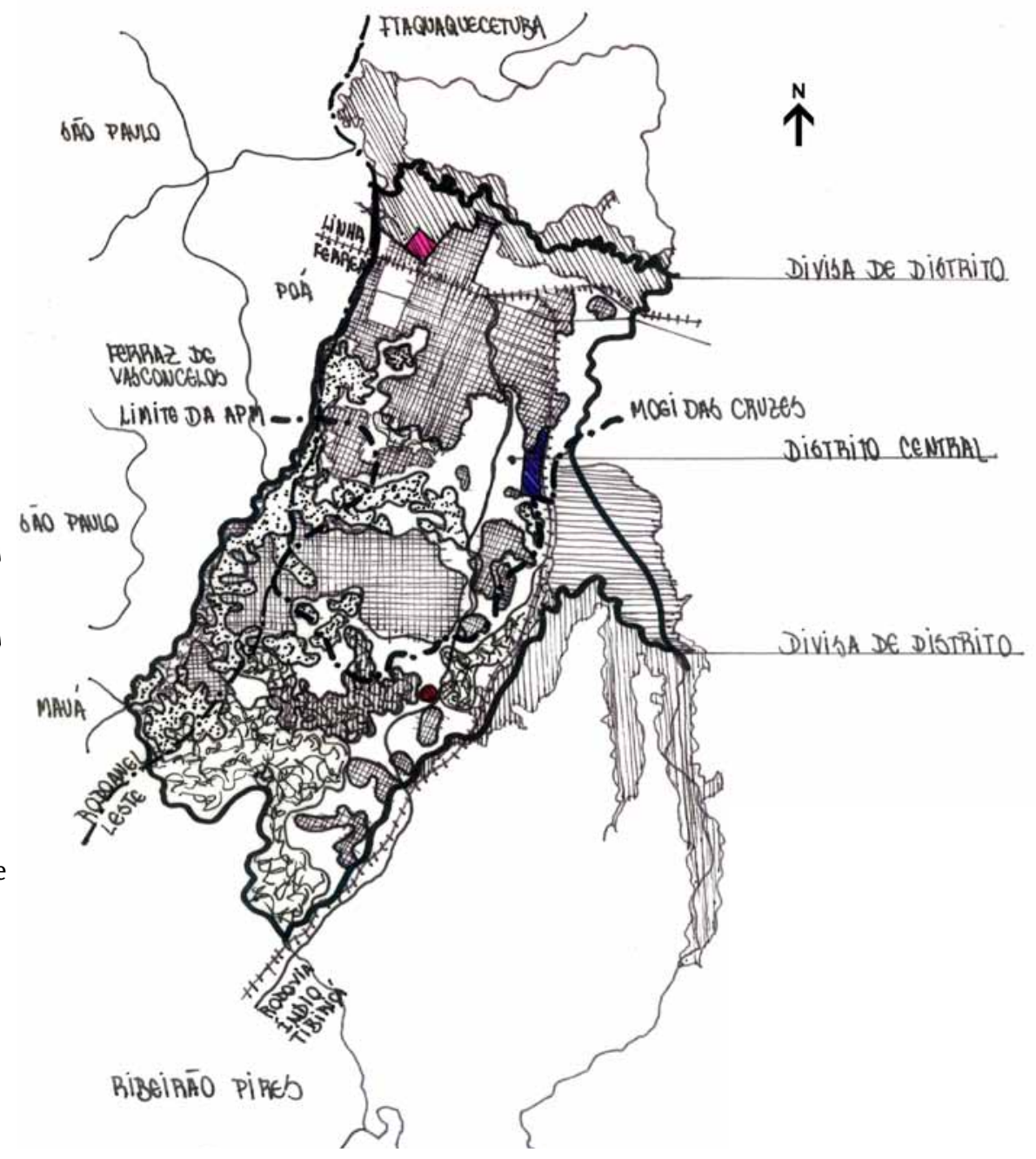


A diversidade com relação ao uso do solo neste distrito, que está parcialmente inserido em Área de Proteção dos Mananciais, é grande. 0 setor localizado mais ao sul é recoberto por amplas porções de vegetação, tais como: matas nativas, capoeira, campos, vegetação de várzea e florestas de eucalipto, além de possuir grandes áreas destinadas à agricultura.

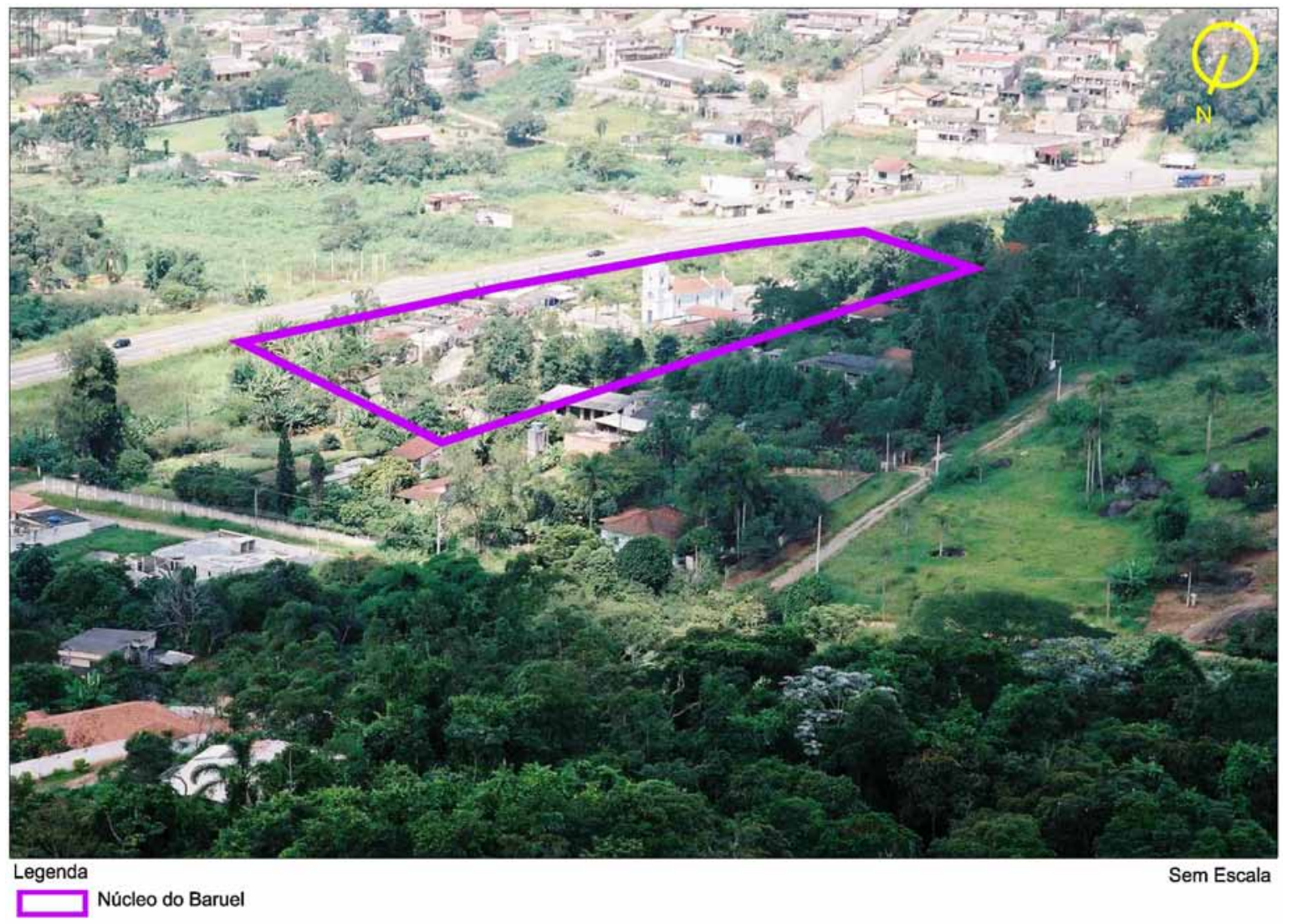

Suzano: Distrito Central. Ocupações junto ao núcleo do Baruel, considerado como o marco zero do território. A flora é a primeira a ser suprimida em razão das alterações promovidas pela ocupação urbana Fonte: Prefeitura Municipal de Suzano, 2008 - imagem organizada por Michele de Sá Vieira e Sanderlei Fernandes Vilanova, 2012 

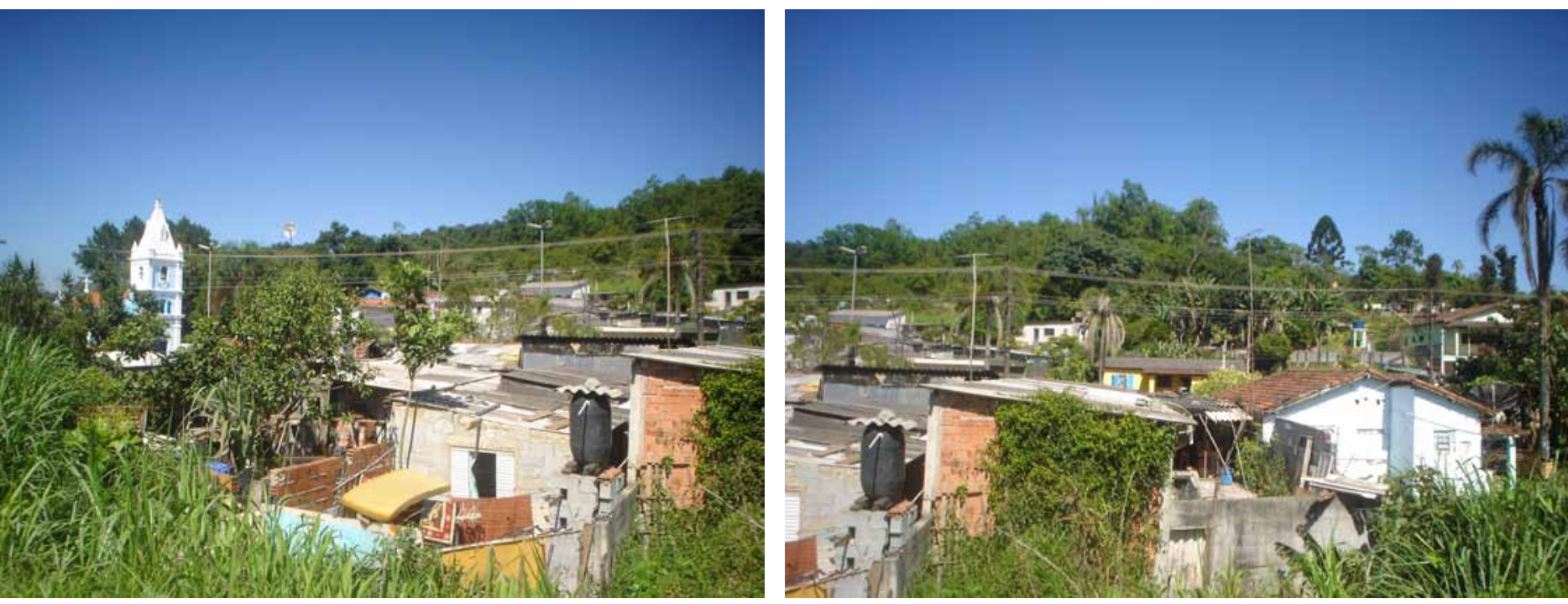

Suzano: Distrito Central - núcleo do Baruel. Percebe-se que parte das ocupações que se dão neste núcleo evidencia um processo de favelização, responsável também pela degradação do ambiente deste espaço Fonte: Prefeitura Municipal de Suzano, 2008
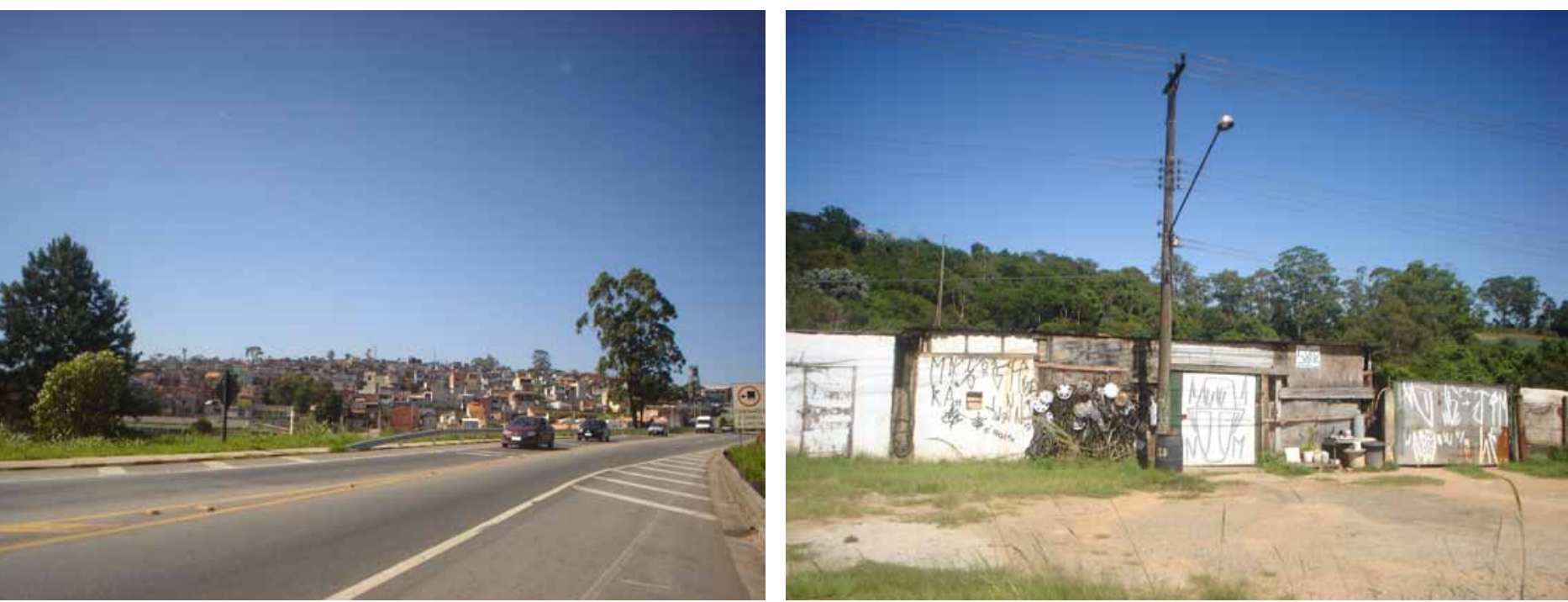

Suzano: Distrito Central. A rodovia Índio Tibiriçá incentivou ocupações junto ao seu percurso e próximas aos fragmentos florestais, este fato acabou contribuindo para com a supressão da vegetação nativa Fonte: Arquivo pessoal - Michele de Sá Vieira, 2011 
Esta região se constitui na principal área urbanizada do município, que tem boa infraestrutura de água e esgoto, contendo inclusive a Estação de Tratamento de Esgoto (ETE) e a Estação de Tratamento de Água (ETA) da SABESP, além de ser cortada pela linha férrea que interliga Suzano à Região Metropolitana.

Nela concentram-se as principais atividades administrativas do Poder Público, além das comerciais e industriais, bem como extensas áreas de moradias de camadas de renda média e alta. 0 que predomina é o padrão horizontal de urbanização, o parcelamento do solo constituido por malha viária regular e as quadras parceladas em lotes, que possibilitam tanto a instalação de comércio, como a construção de residências unifamiliares ou de edifícios de pequeno, médio e grande portes, com uma intensa circulação de pedestres e veículos.

Na área urbanizada existem deficiências no que se refere a aspectos como: o sistema público de drenagem de águas pluviais, a disponibilidade de áreas permeáveis, a quantidade de cobertura vegetal, bem como a alta impermeabilização do solo. Todos estes fatores somados, certamente, contribuem para a ampliação dos problemas frequentes relacionados à drenagem urbana, gerando, como consequência, as inúmeras enchentes que acontecem nas épocas das chuvas.

Observa-se que é na região central de Suzano que se concentram os maiores processos de transformação, por estarem ligadas ao jogo dos agentes do mercado imobiliário, que escolhem os locais para as construções em função de custos e retornos dos investimentos 7 .
${ }^{7} \mathrm{AFONSO}, \mathrm{C}$. M.. A paisagem da Baixada Santista: Urbanização, transformação e conservação. São Paulo: Editora da Universidade de São Paulo: FAPESP, 2006. p. 58. 
8Idem. p. 56

${ }^{9}$ MACEDO, S. S.. Paisagem, urbanização e litoral do éden à cidade. Tese (Livre-Docência) - Faculdade de Arquitetura e Urbanismo, Universidade de São Paulo, São Paulo, 1993.

Suzano: Distrito Central, Rua Baruel. Observa-se que a pequena dimensão das calçadas, assim como a ausência de recuos frontais, prejudicam a implantação de infraestruturas verdes, capazes de abrigar a arborização urbana, bem como facilitar os processos de drenagem propiciados muitas vezes pela permeabilidade gerada pelos canteiros de vegetação

Fonte: Arquivo Michele de Sá Vieira, 2011
Dessa forma, o crescimento urbanístico, ou seja, a intensidade, a direção, a modificação de estruturas viárias, o traçado, o parcelamento, a tipologia dos elementos urbanos, tais como residências e comércio, as articulações como as relações entre os elementos que compõem o espaço urbano, tudo isso está vinculado, em conjunto ou separadamente, aos aspectos socioeconômicos, à cultura de planejamento e aos projetos dos técnicos e gestores públicos, que atuaram na prefeitura, dos técnicos vinculados ao setor privado, além dos interesses do mercado imobiliário. Estes, por muitas vezes, se associam aos interesses do poder público, gerando resultados positivos, mas em outros se têm consequências negativas 8 .

Estes interesses, consequentemente, geraram uma tipologia urbana, que se caracteriza formalmente por possuir áreas muito adensadas em termos construtivos, com recuos reduzidos quando existem, além de calçadas estreitas?.

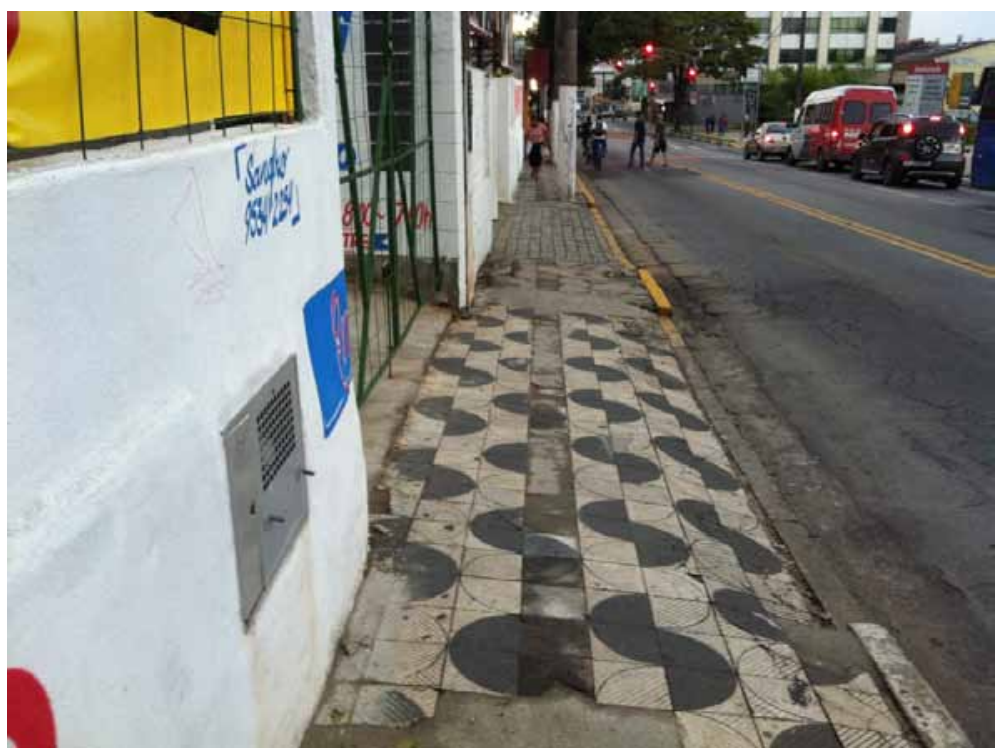



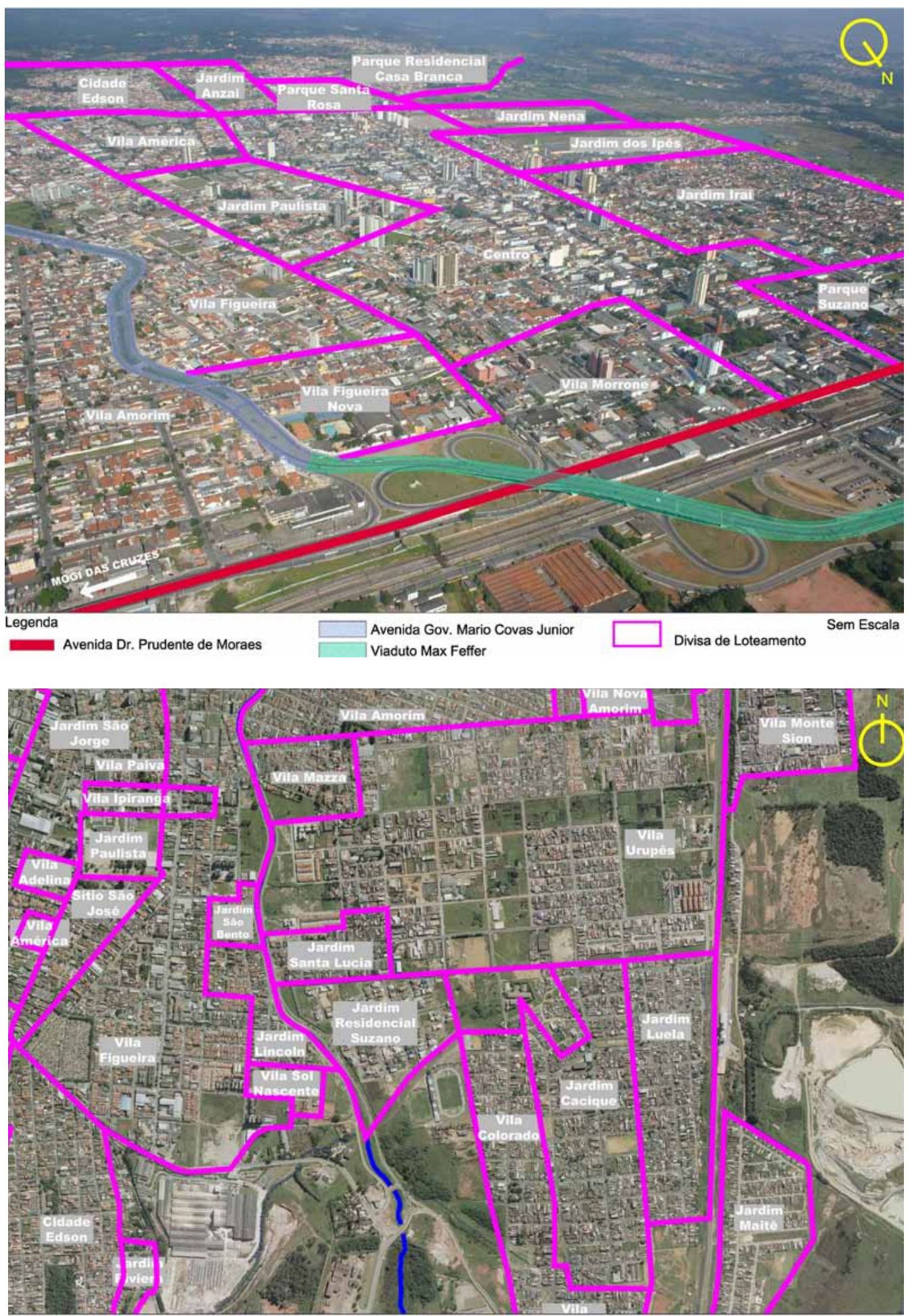

Legenda

Ribeirão Chico da Vargem (rio Una)
Divisa de Loteamento
Suzano: Distrito Central loteamentos Vila Amorim e Vila Figueira, entre outros. A Avenida Prudente de Moraes interliga Suzano a Mogi das Cruzes. Esta é transposta pelo viaduto Max Feffer, o qual se conecta a Avenida Mário Covas Jr., caracterizada por seu traçado sinuoso Fonte: Prefeitura Municipal de Suzano, 2008 - imagem organizada por Michele de Sá Vieira e Sanderlei Fernandes Vilanova, 2012

Suzano: Distrito Central. Nesta porção da cidade, que engloba loteamentos como o Jardim Residencial Suzano, Jardim Luela, Vila Figueira entre outros, ainda existem muitos espaços livres públicos e privados, com alto potencial para serem incorporados no cotidiano da cidade como área de lazer e recreação. Eles se concentram principalmente ao longo do ribeirão Chico da Vargem (rio Una), que se encontra canalizado e sem nenhum plantio nos seus arredores Fonte: Prefeitura Municipal de Suzano, 2008 - imagem organizada por Michele de Sá Vieira e Sanderlei Fernandes Vilanova, 2012 

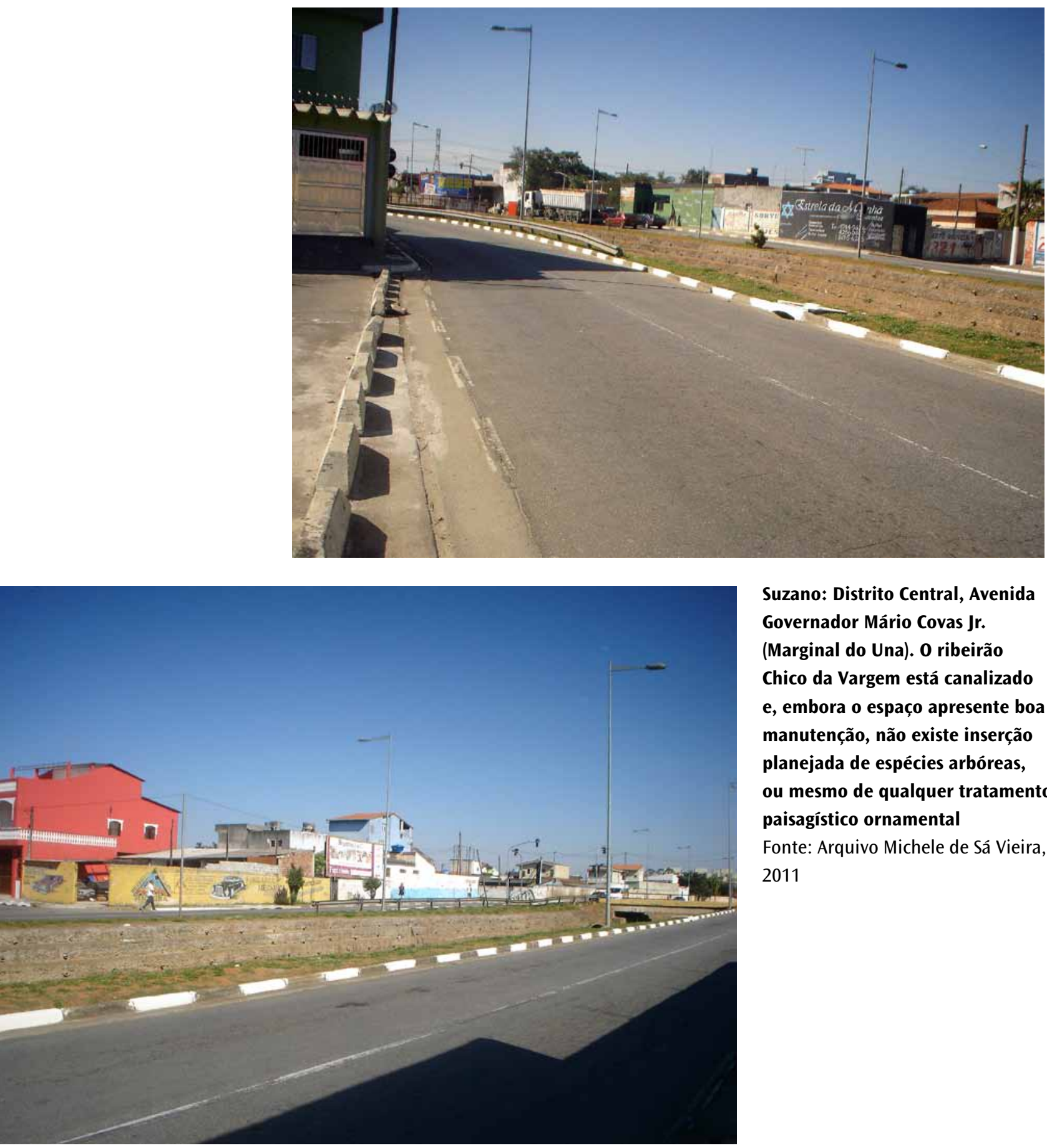

Suzano: Distrito Central, Avenida Governador Mário Covas Jr.

(Marginal do Una). 0 ribeirão

Chico da Vargem está canalizado

e, embora o espaço apresente boa manutenção, não existe inserção planejada de espécies arbóreas, ou mesmo de qualquer tratamento paisagístico ornamental

Fonte: Arquivo Michele de Sá Vieira, 2011 


\section{Distrito de Palmeiras}

Este distrito, que é o menos populoso dos três, contava com uma população de 23.865 habitantes, distribuída por 85,78 km², tendo como delimitação geográfica os municípios de Ribeirão Pires, Rio Grande da Serra, Santo André e Mogi das Cruzes, enquanto dentro do próprio território ao norte é delimitado pela Represa de Taiaçupeba, tendo também próximo ao seu limite a linha férrea ${ }^{10}$.

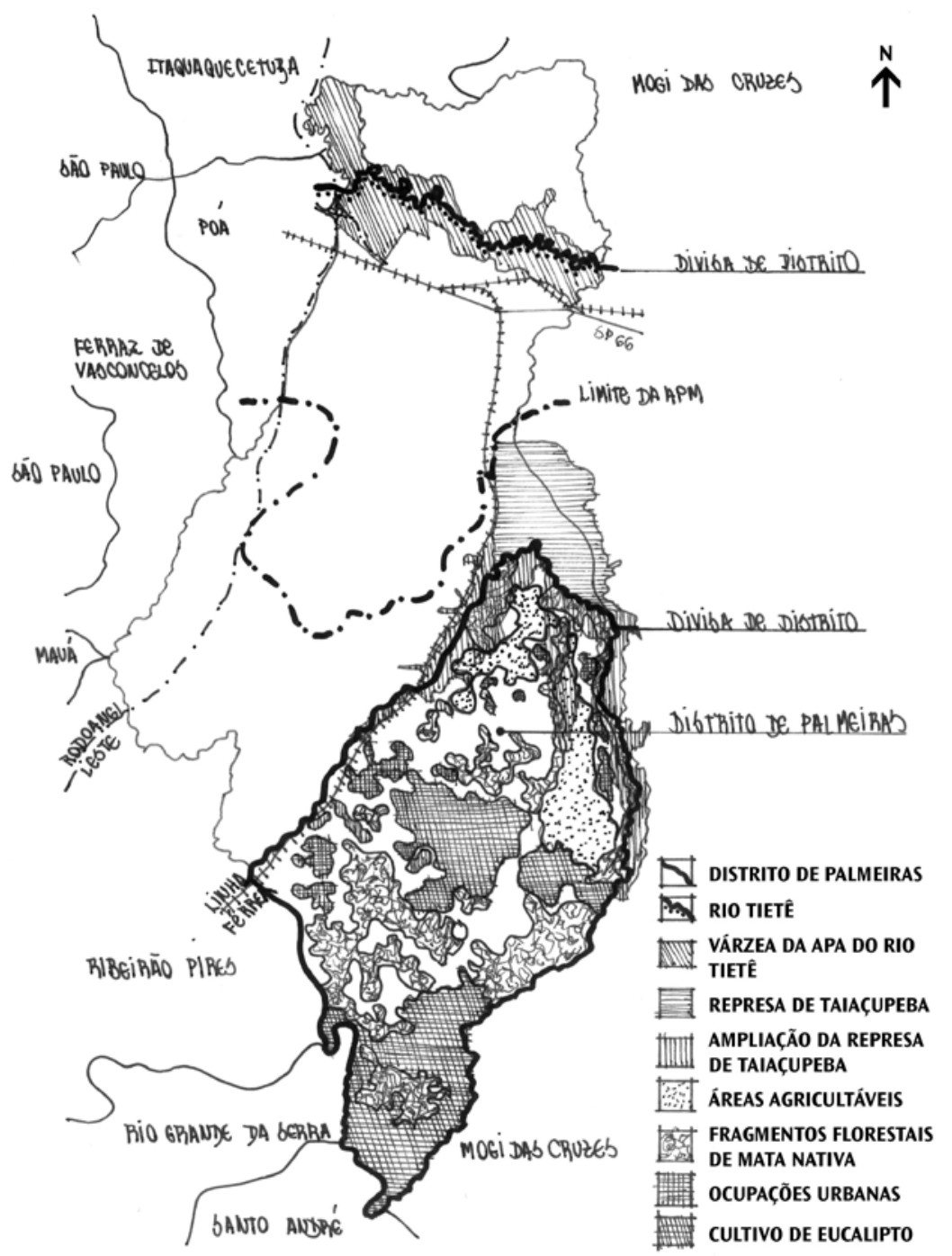

${ }^{10}$ Segundo o censo do IBGE - Instituto Brasileiro de Geografia e Estatística, 2010. < http://www.ibge. gov.br/cidadesat/painel/ painel. php?codmun $=355250>$. Acesso em: 31 de jan. 2012.

Mapa que demonstra a localização do distrito de Palmeiras

Fonte: Desenho criado por Michele de Sá Vieira, 2012 - baseado em mapa (T-1, áreas verdes, distritos e recursos hídricos) da Prefeitura Municipal de Suzano - PMS, 2008 
Suzano: Distrito de Palmeiras -

Presença da vegetação nativa, junto à agricultura nas margens da Rodovia Índio Tibiriçá. Percebe-se que nesta região do território parte da vegetação nativa foi suprimida para que se pudesse implementar a agricultura

Fonte: Prefeitura Municipal de Suzano, 2008 - imagem organizada por Michele de Sá Vieira e Sanderlei Fernandes Vilanova, 2012
A morfologia desta região, a qual está totalmente inserida na Área de Proteção dos Mananciais, se define por ter um relevo acidentado, a presença intensa da agricultura, amplos recobrimentos com diversos tipos de vegetação incluindo reflorestamentos de eucalipto, chácaras de recreio e ocupações urbanas esparsas encravadas no meio da mata nativa.

\section{Agricultura}

Esta atividade ocupa extensos territórios deste trecho do município, dado ao fato de existirem condições ideais para o seu desenvolvimento, como a alta disponibilidade de água necessária ao cultivo das hortaliças, bem como o solo fértil.

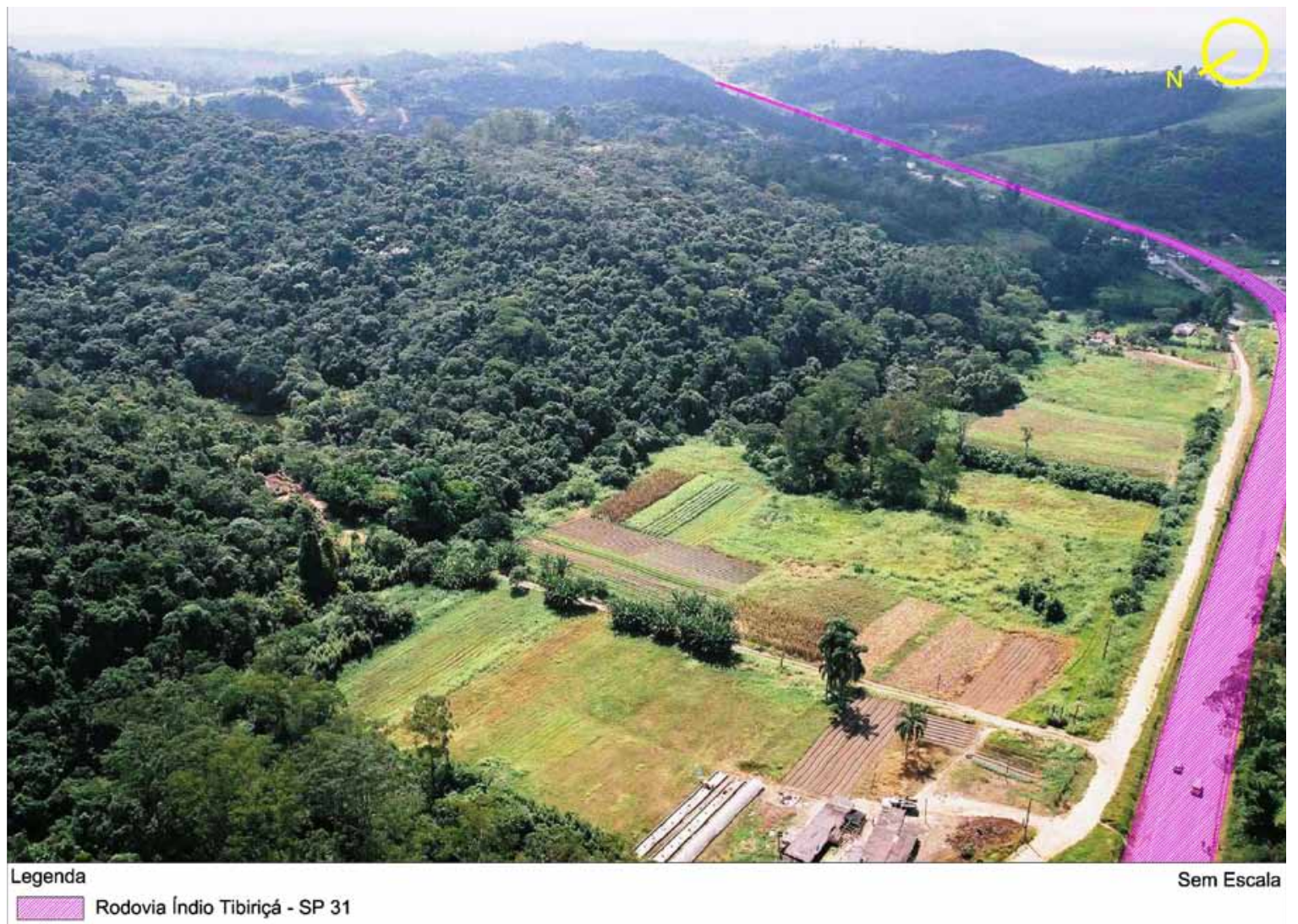




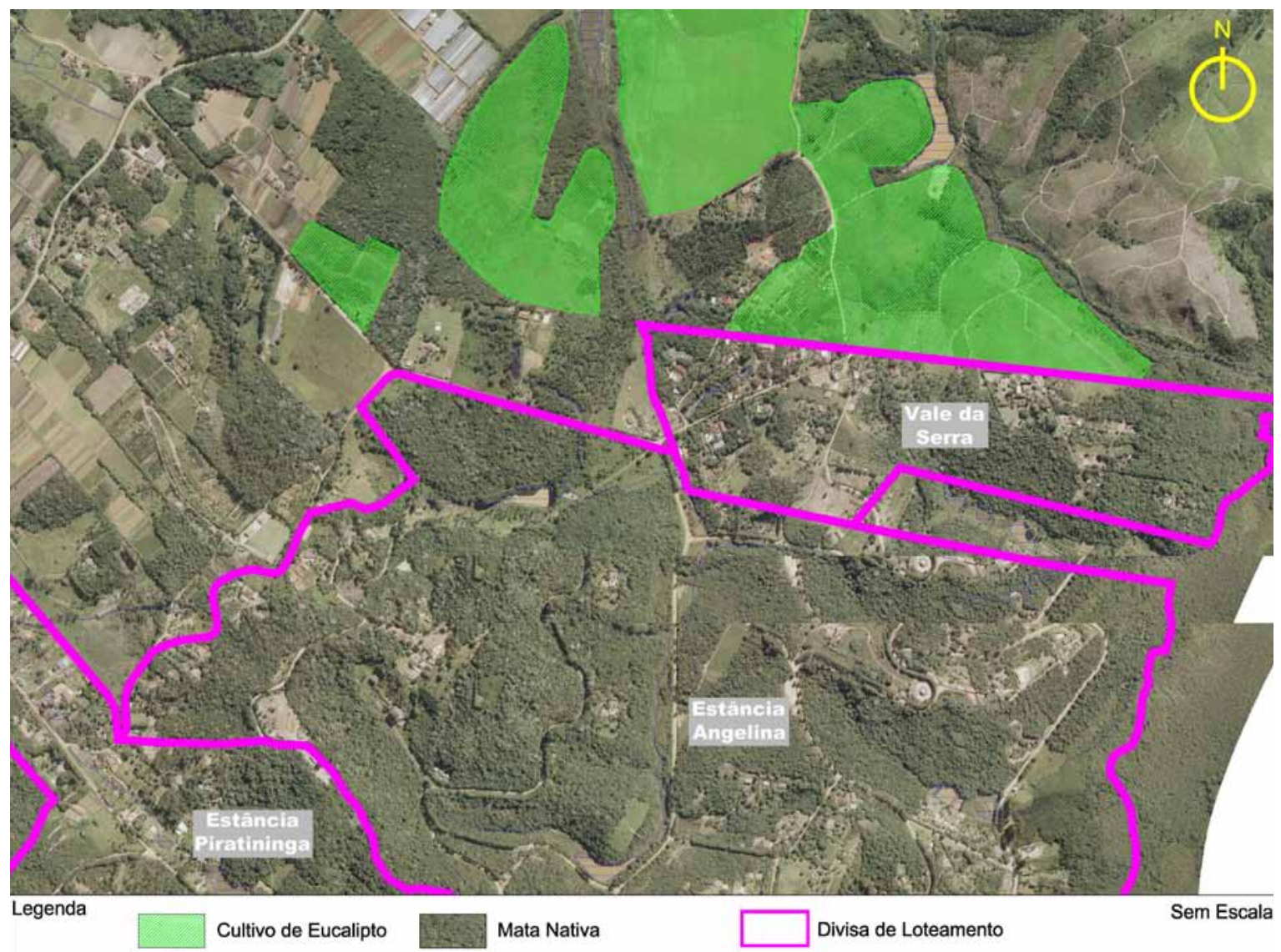

Loteamentos Vale da Serra, Estância Angelina e Estância Piratininga: apresentam sistema viário sinuoso com ocupações encravadas no meio da vegetação de mata nativa. A agricultura também se faz bastante presente no Distrito de Palmeiras, que juntamente com os eucaliptos e as ocupações acabam por contribuir com a diminuição dos fragmentos de mata nativa

Fonte: Prefeitura Municipal de Suzano, 2008 - imagem organizada por Michele de Sá Vieira e Sanderlei Fernandes Vilanova, 2012 


\section{Vegetação}

Ao analisarmos o distrito de Palmeiras verificamos que se coloca de maneira diferenciada, com relação a outras regiões do território, por possuir uma vegetação luxuriante e ecossistemas ainda bem preservados, além de suas terras serem cobertas por

Suzano: Distrito de Palmeiras.

Grandes fragmentos de mata nativa, que estão sendo degradados em função das atividades ilegais vinculadas à exploração mineral

Fonte: Prefeitura Municipal de Suzano, 2008 áreas de mata, capoeira, campos, vegetação de várzea e reflorestamento.

No entanto, o que se observa é que os conflitos nesta área do municipio são latentes justamente pela potência ambiental e ecossistêmica que possui, o que acaba por estimular, dessa forma, a exploração mineral e também com relação à caça.

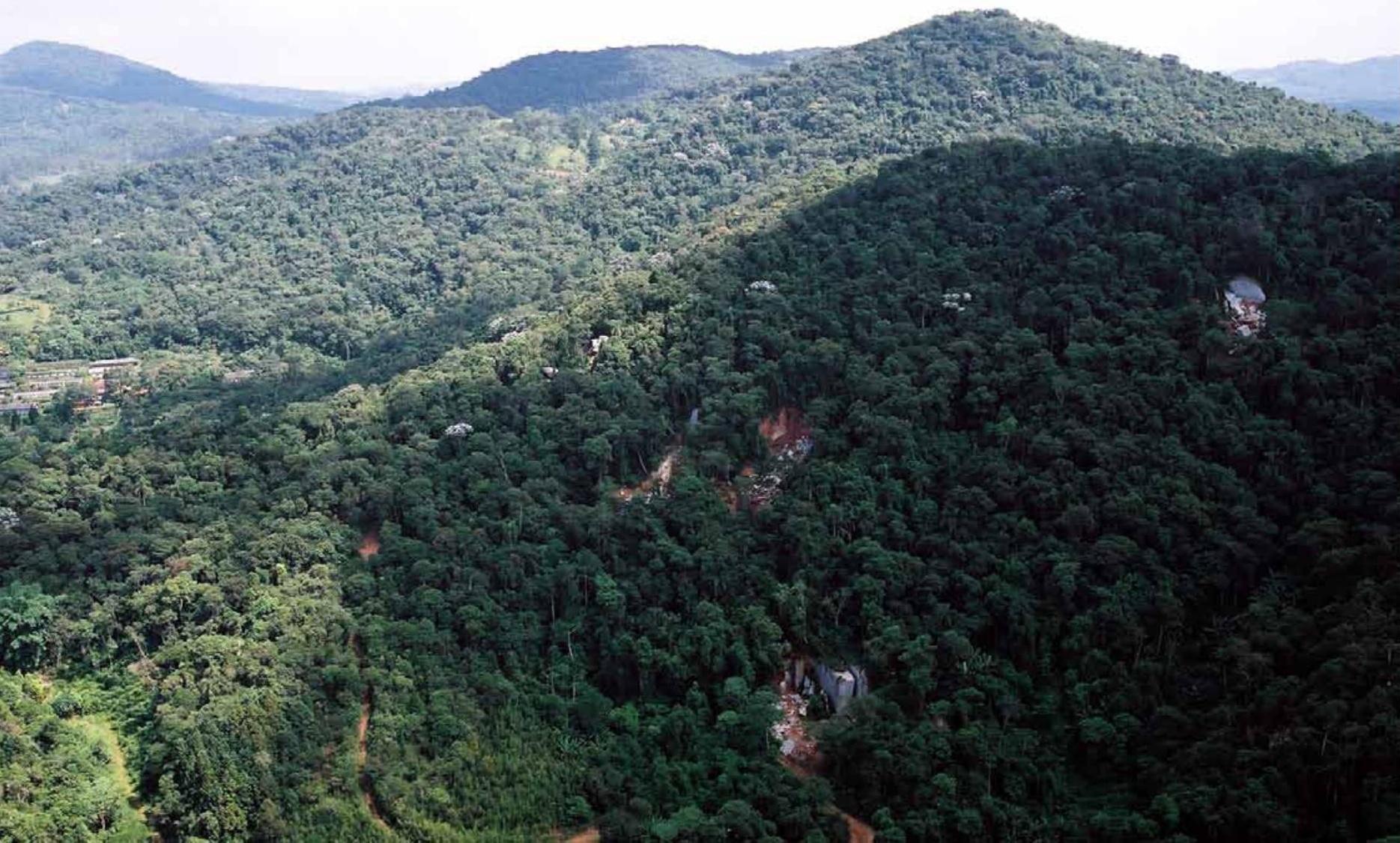




\section{Chácaras de recreio}

"Quando observamos as transformações executadas nos espaços do distrito de Palmeiras, verificamos que há diferenças significativas entre eles, pois ao mesmo tempo que se evidenciam os processamentos dramáticos que os loteamentos populares desenvolvem, por outro lado há aqueles que incorporam os recursos existentes, como águas e pequenos bosques, os quais são muitas vezes conservados e utilizados como componentes do cenário em construção", como se verifica nas chácaras de recreio e pesquei$\operatorname{ros}^{\prime \prime}$.
IIMACEDO, S. S.. Paisagem, urbanização e litoral do éden à cidade. Tese (Livre-Docência) - Faculdade de Arquitetura e Urbanismo, Universidade de São Paulo, São Paulo, 1993. p. 56.

Suzano: Distrito de Palmeiras, loteamento Estância Angelina. A beleza cênica desta região atraiu e ainda atrai chácaras de recreio como evidencia a foto

Fonte: Arquivo Michele de Sá Vieira, 2012

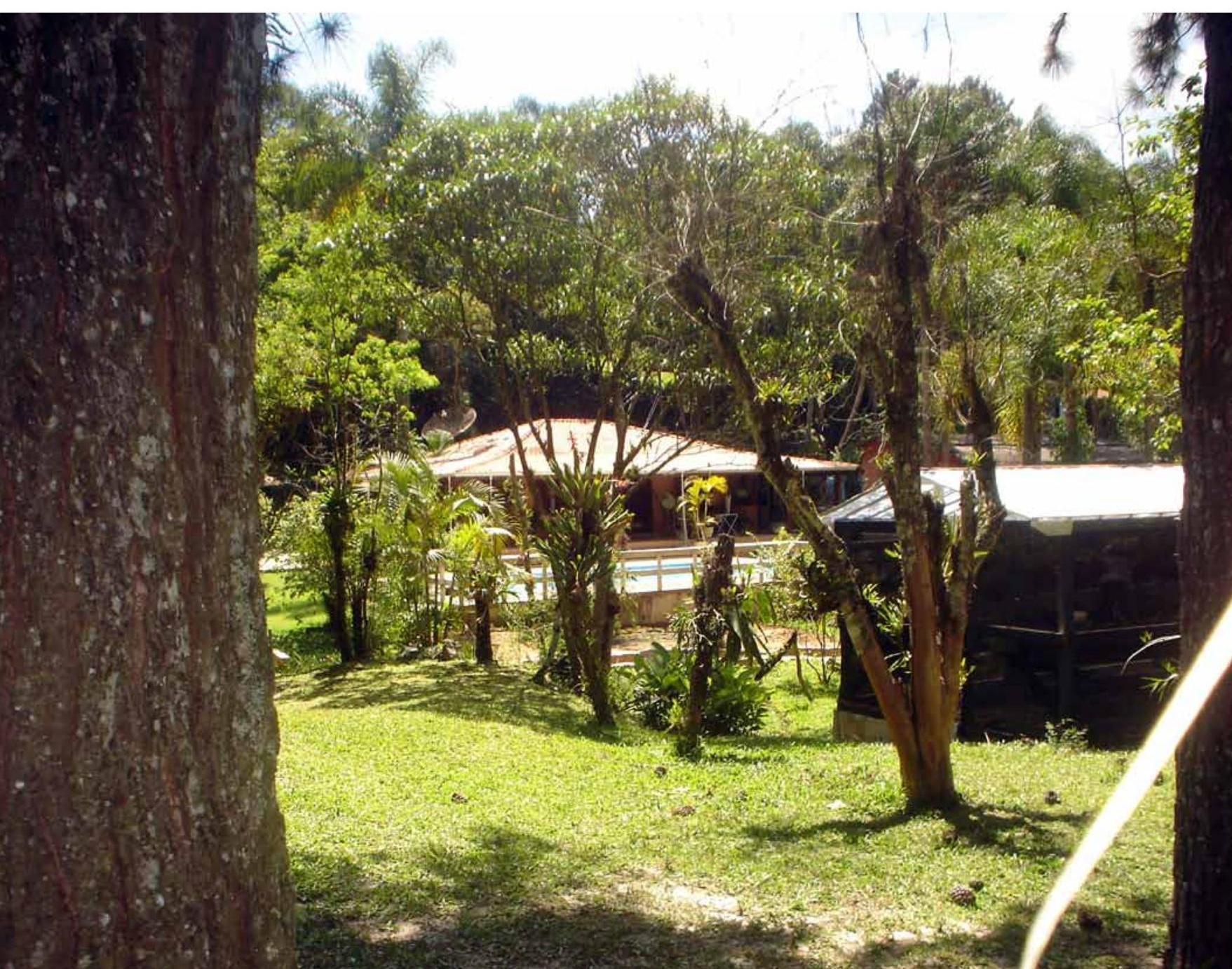




\section{Ocupações urbanas}

Embora as atividades vinculadas à agricultura e ao cultivo de eucalipto tragam perdas ambientais para esta região em função da contaminação do solo por agrotóxicos e da extração do potencial vegetal de mata nativa para que as ações sejam implementadas, a principal causa de degradação deste espaço está ligada às ocupações urbanas, em função do seu padrão de assentamento extremamente precário.

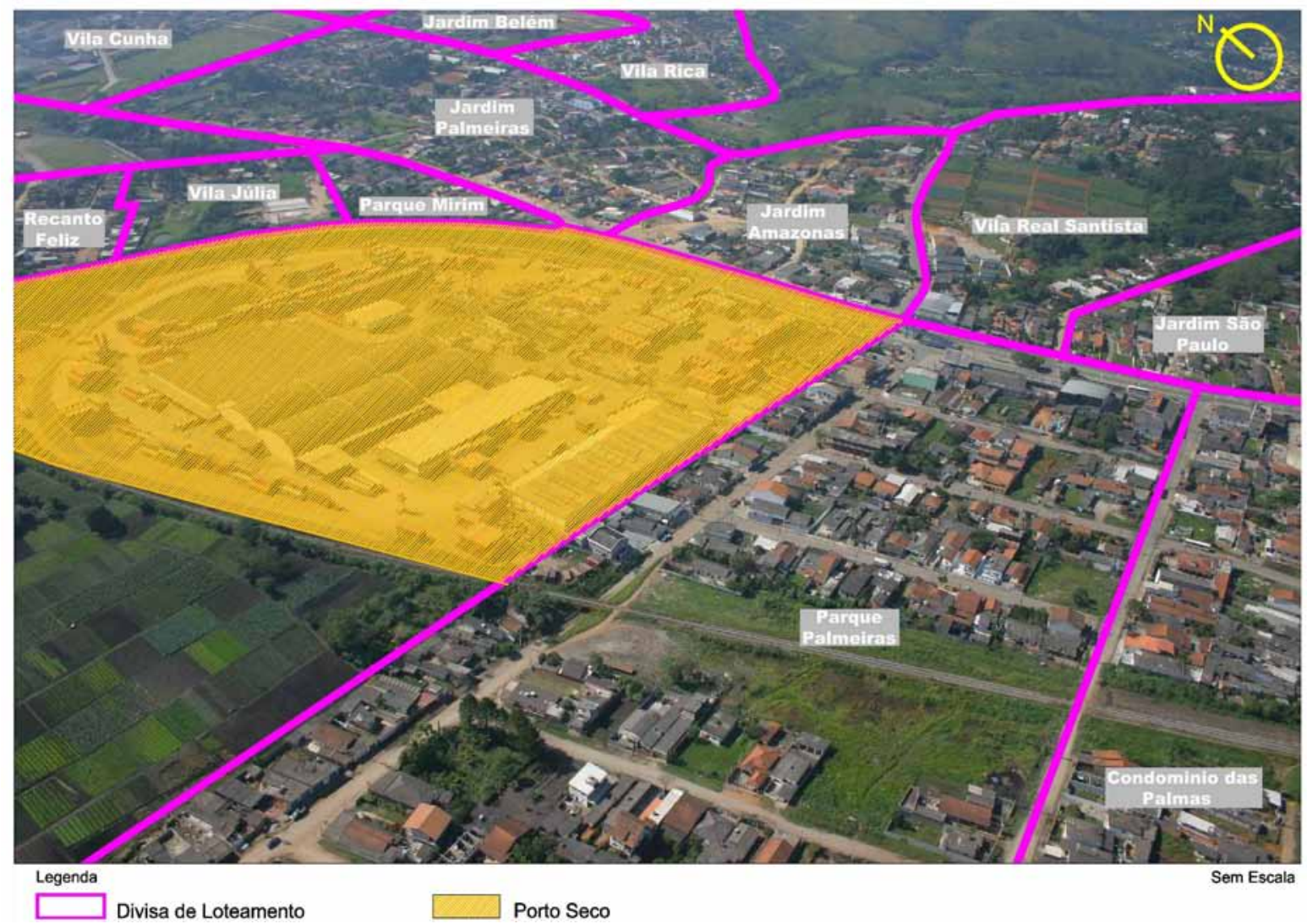

Suzano: Distrito de Palmeiras, loteamentos: Recanto Feliz, Vila Real Santista, Jardim Amazonas, Parque Palmeiras, entre outros, os quais se instalaram de forma precária próximos ao Porto Seco, em Área de Proteção dos Mananciais (APM)

Fonte: Prefeitura Municipal de Suzano, 2008 - imagem organizada por Michele de Sá Vieira e Sanderlei Fernandes Vilanova, 2012 


\section{Urbanização em Área de Proteção dos Mananciais}

Um dos empreendimentos que incentivou as ocupações ao longo da Área de Proteção dos Mananciais, o qual está inserido no distrito de Palmeiras foi o Porto Seco, instalado em 1973, ou seja, antes da legislação vinculada à proteção dos mananciais em 1975.

Este porto, que está situado às margens da rodovia Índio Tibiriça, trata-se de um recinto alfandegado de uso público, em que são executadas operações de movimentação, armazenagem e despacho aduaneiro de mercadorias e de bagagem, sob controle fiscal.

A linha férrea administrada pela Companhia MRS - Logistica, que abastece este porto, atravessa o território longitudinalmente ligando a região de Resende e Volta Redonda ao porto de Santos. Este é administrado pela empresa pública Cragea (Cia. Regional de Armazéns e Entrepostos Aduaneiros).

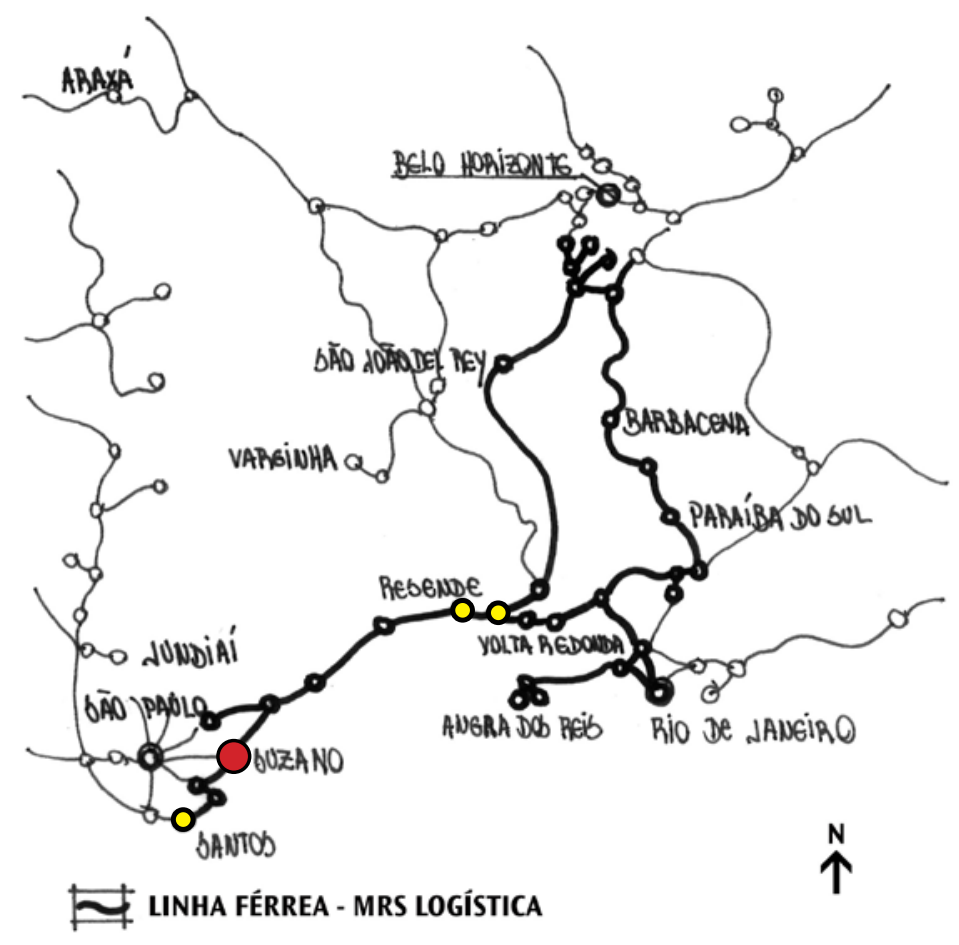

Mapa localizando o município de Suzano junto à linha férrea

Fonte: Desenho criado por Michele de Sá Vieira, 2012 - baseado em mapa do plano diretor da Prefeitura Municipal de Suzano - PMS, 2006 
No entanto, apesar dos investimentos econômicos feitos, entende-se que a presença do equipamento gerou ocupações extremamente conflitantes em relação aos aspectos urbanísticos, de infraestrutura e ambientais devido, em especial, aos diversos loteamentos que o circundam.

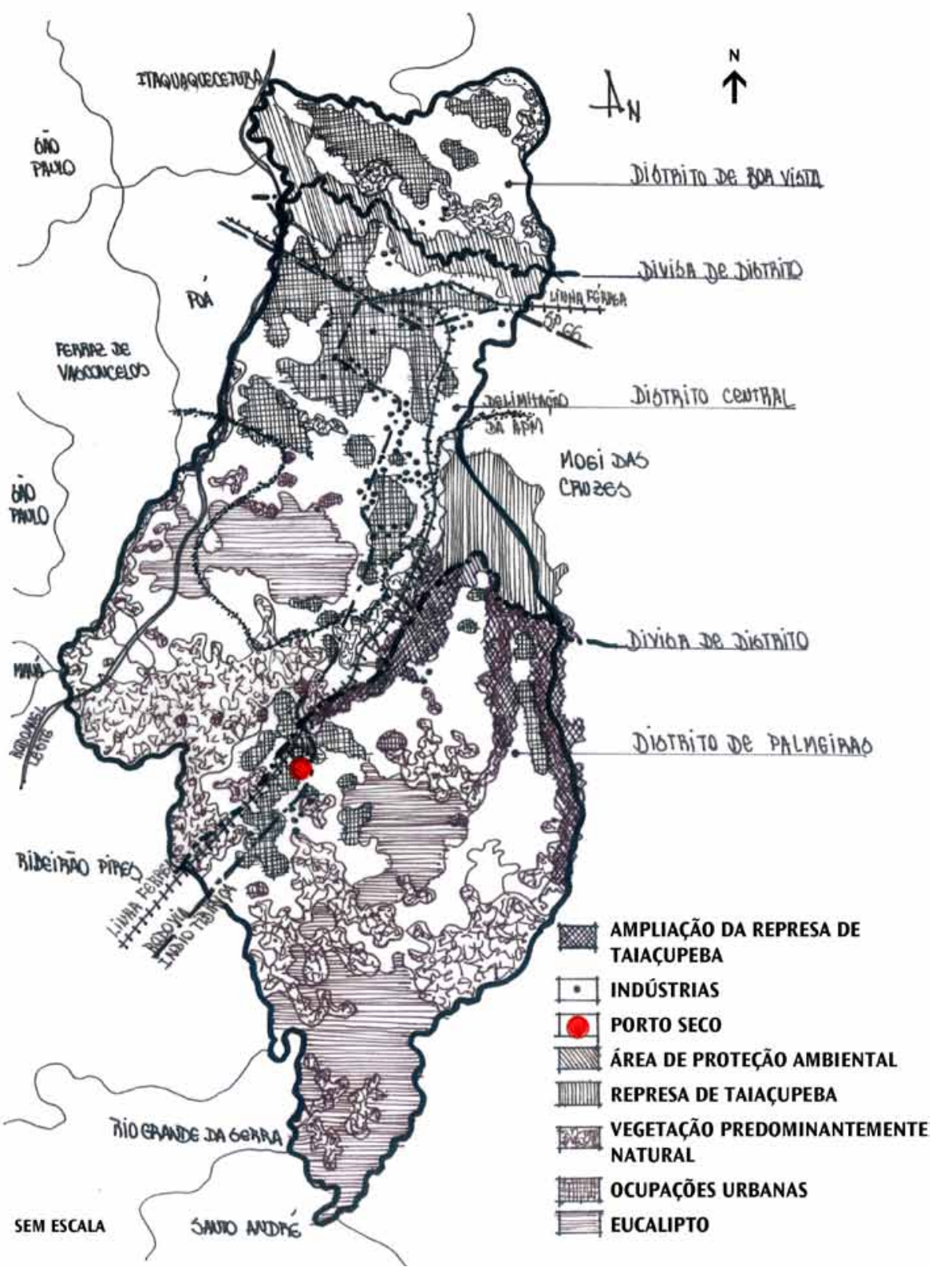




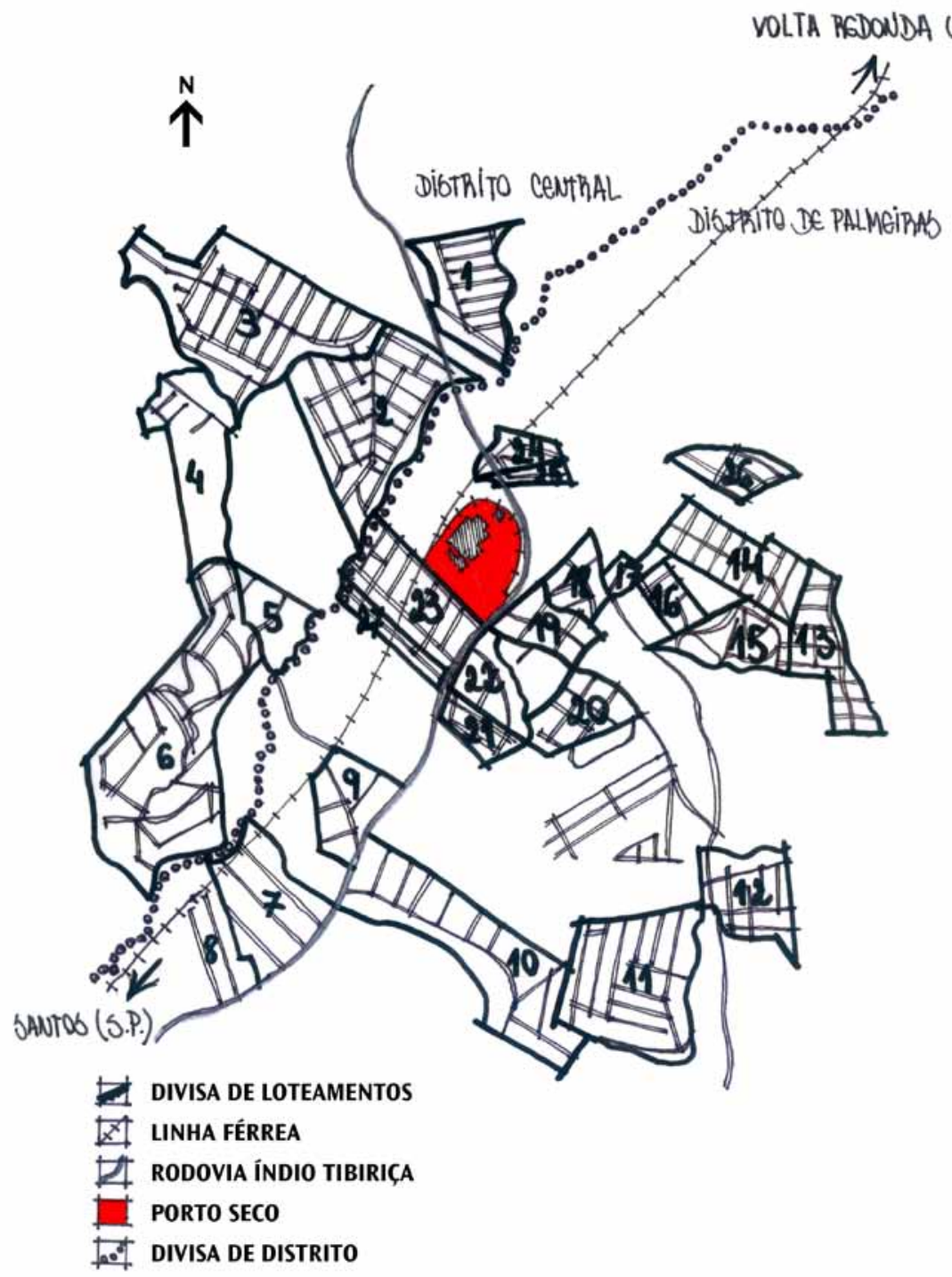

1. Jardim Planalto

2. Parque Buenos Aires

3. Vila Fátima

4. Estância São Luis

5. Recanto Maria de Jesus

6. Parque das Cerejeiras

7. Rincão das Lendas

8. Sítio Santa Gema

9. Jardim Restinga

10. Chácaras São Judas Tadeu

11. Santa Maria

12. Parque Heroísmo

13. Jardim Itamaracá

14. Jardim Belém

15. Vila Real Palmeiras

16. Vila Rica

17. Jardim Palmeiras

18. Jardim Amazonas

19. Vila Real Santista

20. Recreio Bela Vista

21. Jardim Santa Rita de Cássia

22. Jardim São Paulo

23. Parque Palmeiras

24. Recanto Feliz

25. Vila Júlia

26. Recreio das Palmas

27. Condomínio das Palmas

Mapa localizando os diversos loteamentos em torno do Porto Seco

Fonte: Desenho criado por Michele de Sá Vieira, 2012 - baseado em mapa de áreas públicas da Prefeitura Municipal de Suzano - PMS, 2005 


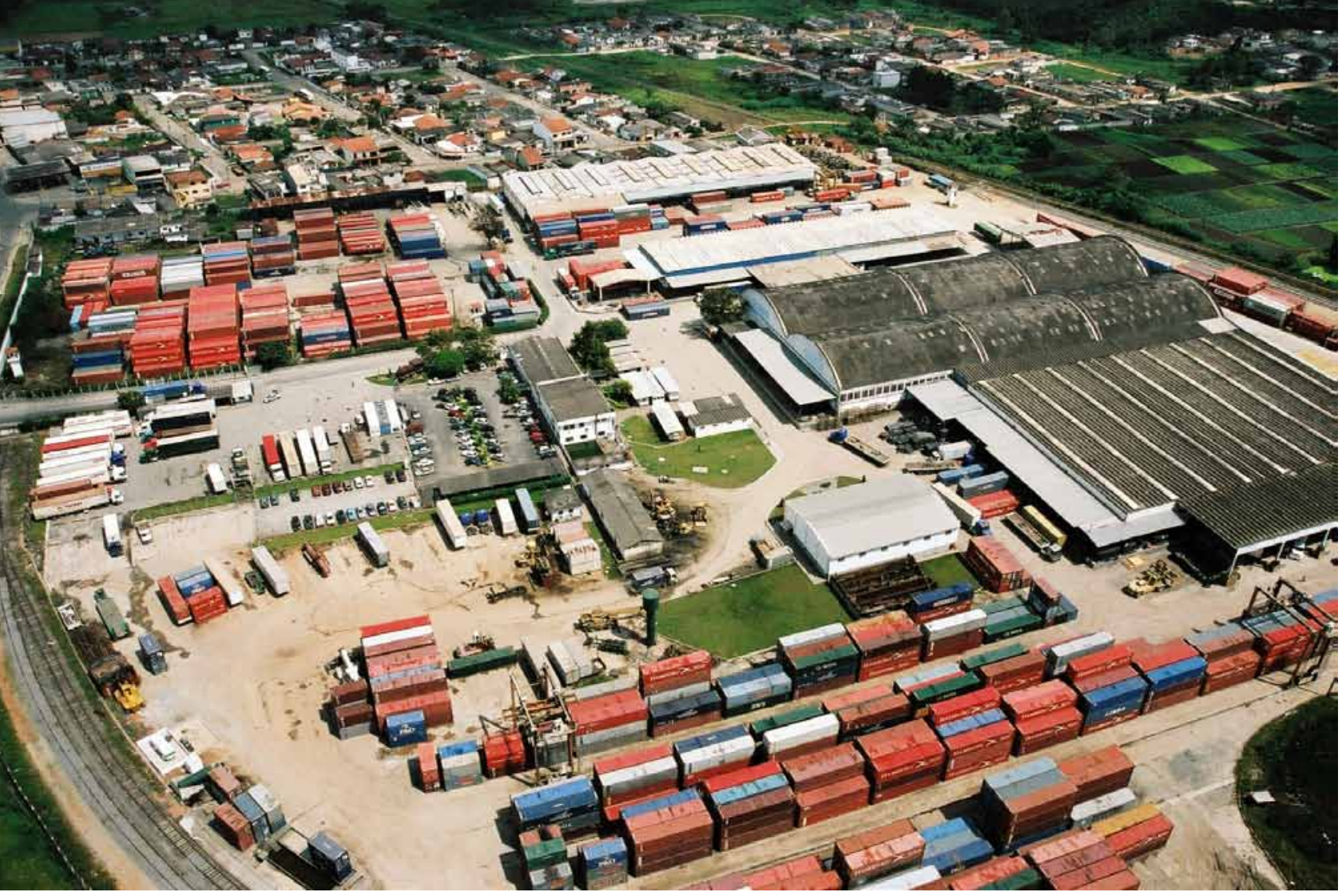

Suzano: Este transporte de carga, que movimenta contêineres $e$ possui como concessionária a empresa MRS Logística S. A. é voltado aos setores de mineração, siderurgia, construção civil, químico e petroquímico, produtos agrícolas, papel e celulose, além dos automotivos

Fonte: Prefeitura Municipal de Suzano, 2008
Ou seja, ao observarmos a relação existente entre o Porto Seco e a região em que se instalou, verificamos que ao longo de anos esta cresceu, no que se refere aos aspectos urbanísticos, quantitativamente com o aumento dos loteamentos. No entanto, como as áreas ocupadas são espaços ambientalmente frágeis, acabaram impedidas pela lei de receber infraestrutura, não permitindo que o território se desenvolvesse urbanisticamente em conformidade tanto com relação às necessidades da população, bem como com o meio ambiente.

Considera-se, pela Lei n. 9.866/97, a qual dispõe sobre diretrizes e normas para a proteção e recuperação das bacias hidrográficas dos mananciais de interesse regional do Estado de São Paulo, que mananciais de interesse regional são as águas interiores subterrâneas, superficiais, fluentes, emergentes ou em depósito, efetiva ou potencialmente utilizáveis para o abasteci- 
mento público. As áreas de mananciais compreendem os espaços do território, percorridas e drenadas pelos cursos d'água desde as nascentes até os rios e as represas.

Estas áreas se encontram protegidas por três leis e um decreto.

A primeira trata-se da Lei Estadual n. 898/75, que disciplina 0 uso do solo para a proteção dos mananciais, cursos e reservatórios de água e demais recursos hídricos de interesse da Região Metropolitana de São Paulo. Esta estabelece para o município de Suzano duas importantes prescrições, que se dão nos Artigos $2^{\circ}$ e $10^{\circ}$.

0 Artigo $2^{\circ}$ define as áreas de proteção de mananciais na Região Metropolitana da Grande São Paulo em dois incisos:

- inciso IX, discorre que o rio Guaió, até o cruzamento com a Rodovia São Paulo - Mogi das Cruzes, na divisa dos municípios de Poá e Suzano, é declarado como área de proteção;

- $\quad$ inciso XIV, estabelece que o rio Taiaçupeba, até a confluência com o Taiaçupeba Mirim, inclusive, na divisa dos municípios de Suzano e Mogi das Cruzes, é considerado como área de proteção.

A segunda prescrição, do Artigo $10^{\circ}$, se refere às urbanizações e atividades existentes ou exercidas anteriormente a esta lei, colocando que estas gozarão de prazo adequado para se adaptarem às suas exigências ou procederem à sua transferência para outro local e, na impossibilidade de o fazerem poderão ser submetidas a indenização ou desapropriação. 
A segunda refere-se à Lei Estadual n. 1.172/76, que delimita as áreas de proteção relativas aos mananciais, cursos e reservatórios de água, segundo o Artigo $2^{\circ}$ da Lei n. 898/75.

No entanto, observa-se que embora o objetivo desta legislação tenha sido o de proteger os mananciais, tanto para o município de Suzano, quanto para os outros que ela atinge, sua aplicação acabou por gerar descompassos, pois diversas atividades e loteamentos continuaram se instalando após a data de 1975, e sendo eles considerados como irregulares, consequentemente, foram impedidos por lei, de receberem investimentos como o saneamento básico, voltado ao abastecimento de água e ao esgotamento sanitário, o que acabou e acaba por acarretar problemas sociais e ambientais.

Sociais, dado ao fato da ausência de água tratada prejudicar a saúde da população e ambientais na medida em que a não existência da coleta e tratamento de esgoto induz a população a lançar o esgoto "in natura" nos corpos d'água, provocando a sua contaminação, os quais são encaminhandos em parte para a represa de Taiaçupeba.

A terceira lei discorre sobre a Lei Estadual n. 9.866/97, que dispõe sobre diretrizes e normas para a proteção e recuperação das bacias hidrográficas dos mananciais de interesse regional do Estado de São Paulo e dá outras providências, estabelecendo assim novos critérios e procedimentos para a proteção dos mananciais do Estado de São Paulo.

0 que esta Lei Estadual propõe de inovação, com relação à legislação anterior a 1970, é o fato de ela possuir abrangência em todo o Estado de São Paulo e não apenas na região metropolitana, 
além disso, propõe a confecção de Leis Específicas, Planos de Desenvolvimentos (PDPA) e Planos Emergenciais para as sub-bacias da Região Metropolitana de São Paulo, o que representa, sem dúvida, um avanço para a política de mananciais, com relação à gestão dos recursos hídricos no Estado.

Com relação aos seus Capítulos, destacamos o I, IV e VI:

0 Capítulo I, que trata dos "Objetivos e Abrangências", em seu Artigo $2^{\circ}$, no inciso II, coloca-se a necessidade quanto à compatibilização das ações de preservação dos mananciais de abastecimento e as de proteção ao meio ambiente, com o uso e ocupação do solo e o desenvolvimento socioeconômico.

Ou seja, o intuito deste inciso é garantir um zoneamento, que seja capaz de preservar os mananciais e, consequentemente, a produção de água, a qual contribui para o abastecimento. Como exemplo Suzano pode ser citada, pois neste momento (2012), dentro da Lei Específica que está em elaboração, para o zoneamento junto a bacia do Taiaçupeba, há a previsão de serem mantidas zonas de baixa densidade populacional, além de ações vinculadas à recuperação de áreas degradadas, através da recuperação florestal a serem propostas no Plano de Desenvolvimento de Proteção Ambiental, com previsão de ser executado após o término da Lei Específica.

No que se refere ao Capitulo IV, o qual trata do "Disciplinamento da Qualidade Ambiental", este coloca em seu Artigo 12, que nas APRMs, para a aplicação de dispositivos normativos de proteção, recuperação e preservação dos mananciais e para a implementação de políticas públicas, serão criadas as áreas de intervenção vinculadas à Restrição à Ocupação, à Ocupação Dirigida 
e a de Recuperação Ambiental, as quais se encontram descritas no Artigo 14.

Para Suzano, assim como para os demais municípios que compõem as APRMs, o Artigo 14 é de extrema relevância, pois define que Áreas de Ocupação Dirigida são aquelas de interesse para a consolidação ou implantação de usos rurais e urbanos, desde que atendidos os requisitos que garantam a manutenção das condições ambientais necessárias à produção de água em qualidade e quantidade para o abastecimento das populações atuais e futuras.

Nesse sentido, a interpretação da Lei demonstra que diversas áreas, que hoje (2012) são consideradas irregulares, podem através das Leis Especificas estarem apontadas como Áreas de Ocupação Dirigida, tendo, portanto, a possibilidade de serem passíveis de regularização e, assim, receberem infraestrutura voltada à urbanização.

Para tanto, a minuta da Lei Específica da Bacia Hidrográfica do Alto Tietê Cabeceiras está, em 2012, sendo desenvolvida, inicialmente através de levantamentos de dados vinculados às características físicas e aos planos diretores dos municípios pela Câmara Técnica de Planejamento, que compõe, conjuntamente com a Câmara Técnica de Educação Ambiental e o Grupo Técnico de Monitoramento Hidrológico, a equipe de trabalho que estuda e formula pareceres sobre assuntos de relevância técnica do Subcomitê da Bacia do Alto Tietê Cabeceiras a serem deliberados pela plenária do Subcomitê desta Bacia.

Esta Lei, por consequência, apoiará a cobrança pelo uso da água no Alto Tietê Cabeceiras, posto que uma de suas funções é a de apontar onde os recursos advindos da cobrança deverão ser 
aplicados, sendo que uma das possibilidades é financiar a elaboração do Plano de Desenvolvimento de Proteção Ambiental (PDPA).

A cobrança pelo uso da água está prevista na Lei n.12.183/05, a qual dispõe sobre a cobrança pela utilização dos recursos hídricos do domínio do Estado de São Paulo, os procedimentos para fixação dos seus limites, condicionantes e valores.

Assim, o Artigo $1^{\circ}$, desta Lei, coloca que a cobrança pela utilização dos recursos hídricos objetiva reconhecer a água como bem público de valor econômico e dar ao usuário uma indicação do seu valor.

Uma questão importante, colocada pelo Artigo $2^{\circ}$, é que a cobrança pela utilização dos recursos hídricos será vinculada à implementação de programas, projetos, serviços e obras, de interesse público, da iniciativa pública ou privada, definidos nos Planos de Recursos Hidricos, aprovados previamente pelos respectivos Comitês de Bacia e pelo Conselho Estadual de Recursos Hidricos.

0 Artigo $3^{\circ}$ trata de outro aspecto fundamental, indicando que o Comitê da Bacia Hidrográfica do Alto Tietê deverá destinar, pelo período de 10 (dez) anos, no mínimo 50\% (cinquenta por cento) dos recursos de investimento oriundos da cobrança para conservação, proteção e recuperação das áreas de mananciais que atendam a sua área de atuação.

Com isto, a cobrança pelo uso da água passa a ser uma grande oportunidade para a recuperação das áreas junto aos mananciais, que foram degradadas por tantos anos ${ }^{12}$.

Com relação ao Capítulo VI, que trata do "Plano de Desenvolvimento e Proteção Ambiental", especificamente no Artigo 31,
12 A dúvida que se coloca, com relação à disponibilidade de recursos, é saber se os municípios que serão beneficiados por eles terão capacidade técnica para desenvolver projetos suficientemente qualificados para a captação destes recursos financeiros. 
coloca que para cada Área de Proteção dos Mananciais - APRM, será elaborado um Plano de Desenvolvimento e Proteção Ambiental - PDPA.

Entre as diversas questões apontadas, o Artigo 31 discorre sobre a necessidade de serem desenvolvidas, dentro do PDPA, diretrizes para o estabelecimento de políticas setoriais relativas à habitação, transporte, manejo de recursos naturais, saneamento ambiental e infraestrutura que interfiram na qualidade dos mananciais, além de metas de curto, médio e longo prazo, para a obtenção de padrões de qualidade ambiental, entre outras propostas e programas.

No entanto, na prática, observa-se que as leis comentadas não foram eficazes para diversos territórios, incluindo o de Suzano, pois somente a partir do Decreto Estadual n. 43.022/98, o qual regulamentou dispositivos relativos ao Plano Emergencial de Recuperação dos Mananciais da Região Metropolitana da Grande São Paulo, de que trata a Lei n. 9.866/97, que neste município, cerca de 25 loteamentos inseridos em APM passaram a receber obras de urbanismo e infraestrutura, enquanto 65 loteamentos continuam, neste momento (2012), impedidos pela lei de receber tais beneficios como demonstra o mapa. 


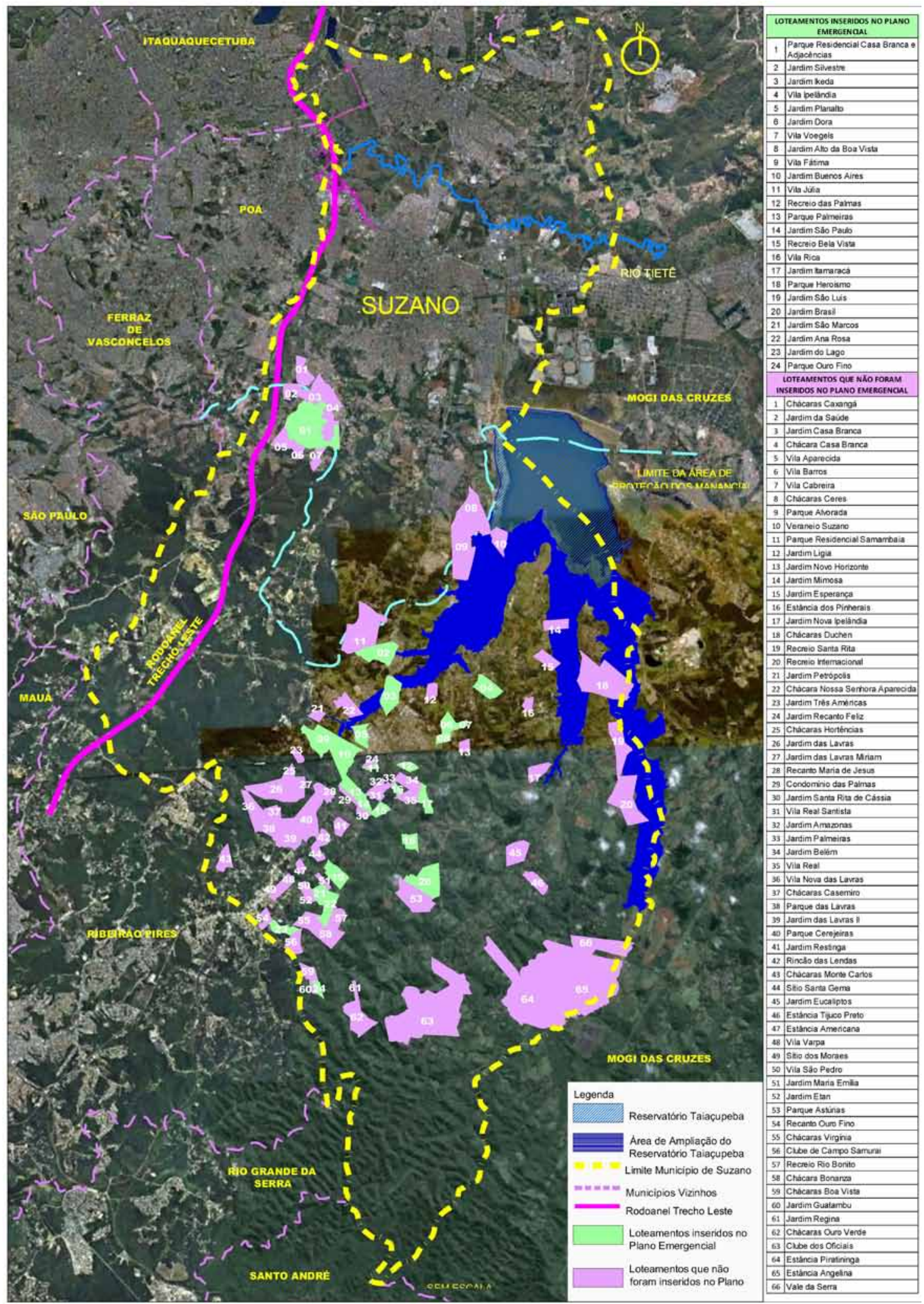

Mapa localizando na Área de Proteção dos Mananciais - APM, os loteamentos que foram inseridos no Plano Emergencial e também aqueles que não foram incluídos no mesmo

Fonte: Desenho criado por Michele de Sá Vieira e Sanderlei Fernandes Vilanova (2012), a partir de imagens do Google, acessadas em dezembro de 2011 e planta base - denominação de loteamentos da Prefeitura Municipal de Suzano, 2006 
Dessa forma, o Plano Emergencial, em seu Artigo $1^{\circ}$ e $\S 2^{\circ}$, autorizou os municípios e as concessionárias a realizarem intervenções como: abastecimento de água, esgotamento sanitário, drenagem de águas pluviais, contenção de erosão, prevenção e controle de poluição das águas, estabilização de taludes, fornecimento de energia elétrica e revegetação, objetivando diminuir os impactos ambientais causados pelo lançamento do esgoto "in natura" nos corpos d'água, assoreamento dos rios, bem como pela falta de drenagem adequada, entre outros.

Mapa localizando na Área de Proteção dos Mananciais, os loteamentos Parque Residencial Casa Branca, Jardim Ikeda e Jardim Brasil

Fonte: Desenho criado por Michele de Sá Vieira, 2012 - baseado em mapa de áreas públicas da Prefeitura Municipal de Suzano PMS, 2005

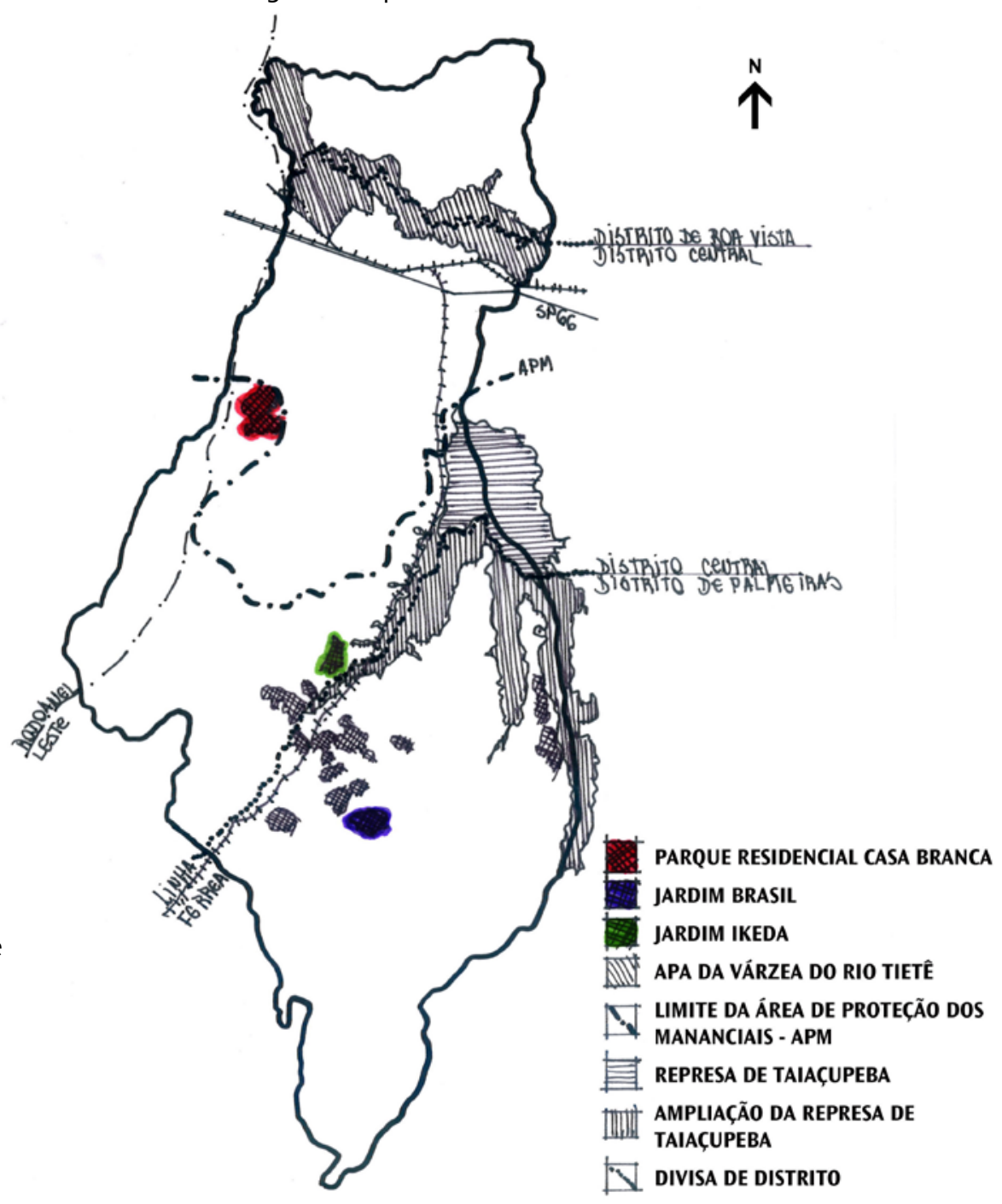


Assim, observa-se que embora todas as leis comentadas tenham sido feitas visando a proteção dos mananciais, diversos locais foram ocupados, irregularmente, por loteamentos como 0 Parque Residencial Casa Branca, Jardim Ikeda e o Jardim Brasil. Dessa forma, objetivando implantar a política municipal de habitação, bem como a valorização dos recursos naturais, as famílias, que se encontravam nestes locais, foram retiradas em 2009, através de ações executadas pela Prefeitura Municipal de Suzano.

Com isto, resta saber se as diretrizes estabelecidas pelas Leis Específicas e pelos Planos de Desenvolvimento de Proteção Ambiental, assim como os recursos advindos da Cobrança pelo Uso da Água serão suficientes para superar minimamente os grandes descompassos existentes nas Áreas de Proteção de Mananciais, gerados em parte por gestões criminosas e ineficientes do Poder Público vinculado à metrópole paulistana.

\section{Sobre os distritos}

Embora entenda-se que toda e qualquer urbanização traga mudanças ao ambiente original, pode-se afirmar que os padrões convencionais de tecido urbano estabelecidos em Suzano, foram altamente incompativeis com o ambiente e a paisagem natural do município, mediante a destruição quase total ou parcial que eles provocaram nos ambientes, exigindo assim a completa ou parcial reconstrução do local'3.

Com isto, a maior parte da população, que vive nas áreas urbanizadas de Suzano como os distritos de Boa Vista e Central, perdem o benefício de conviver com a existência da vegetação nativa nas suas áreas de moradia, sendo que esta convivência passa
13 MACEDO, S. S.. Paisagem, urbanização e litoral do éden à cidade. Tese (Livre-Docência) - Faculdade de Arquitetura e Urbanismo, Universidade de São Paulo, São Paulo, 1993. p. 56. 
${ }^{14} \mathrm{AFONSO}$, C. M.. A paisagem da

Baixada Santista: Urbanização, transformação e conservação. São Paulo: Editora da Universidade de São Paulo; FAPESP, 2006. p. 56.

15 Ibid, p. 56.

16।bid, p. 57. a ser usufruída por apenas uma pequena parcela da sociedade que vive em Palmeiras.

Assim, ao analisarmos as formas de ocupação dos três distritos, observa-se que os assentamentos realizaram constantemente altos graus de processamento no território, pois para a construção dos arruamentos, dos equipamentos coletivos de efeito cênico como das praças, das indústrias, do comércio, habitação e agricultura, fez-se necessário promover drásticas transformações no ambiente $^{14}$. Por isso, de maneira geral, os loteamentos nos três distritos submeteram a paisagem a um modelo rígido de desenho, o que causou perdas reais dos valores paisagísticos e ambientais do território.

Isto aconteceu por diversas razões, como por exemplo, em função do modelo de urbanização ser incompativel com alguns aspectos vinculados ao ambiente como o relevo, assim, a malha urbana acabou sendo implantada de modo tradicional, colocando-se de forma reticulada ou curvilínea ${ }^{15}$. Esta incompatibilidade, por sua vez, remete a conflitos que se expressam através de problemas vinculados à drenagem urbana, como as enchentes, dado ao incorreto encaminhamento das águas da chuva, a impermeabilização do solo gerada pela pavimentação das áreas ocupadas próximas aos corpos d'água, além da retirada da vegetação, que causam grandes alterações no suporte físico ${ }^{16}$.

Para além das questões vinculadas ao urbanismo verifica-se, também, conflitos ligados à vegetação, isto porque em muitos momentos o fragmento nativo é ignorado. Ou seja, a Mata Atlântica é considerada, por vezes, como um elemento esteticamente agressivo e incompatível com o padrão de beleza socialmente estabelecido, onde somente algumas espécies são consideradas e tidas como 
"belas". Assim, ela é desprezada na composição dos loteamentos, esquecendo-se que a agressividade das espécies nativas também pode compor a beleza cênica dos espaços. Nota-se, dessa forma, que a vegetação usada no cotidiano é adquirida e criada em viveiros, de acordo com os padrões estéticos dos gestores públicos, arquitetos, paisagistas e da sociedade. 
ENTRE AS SERRAS: SISTEMA DE ESPAÇOS LIVRES PÚBLICOS, UMA REFLEXÃO PARA SUZANO 


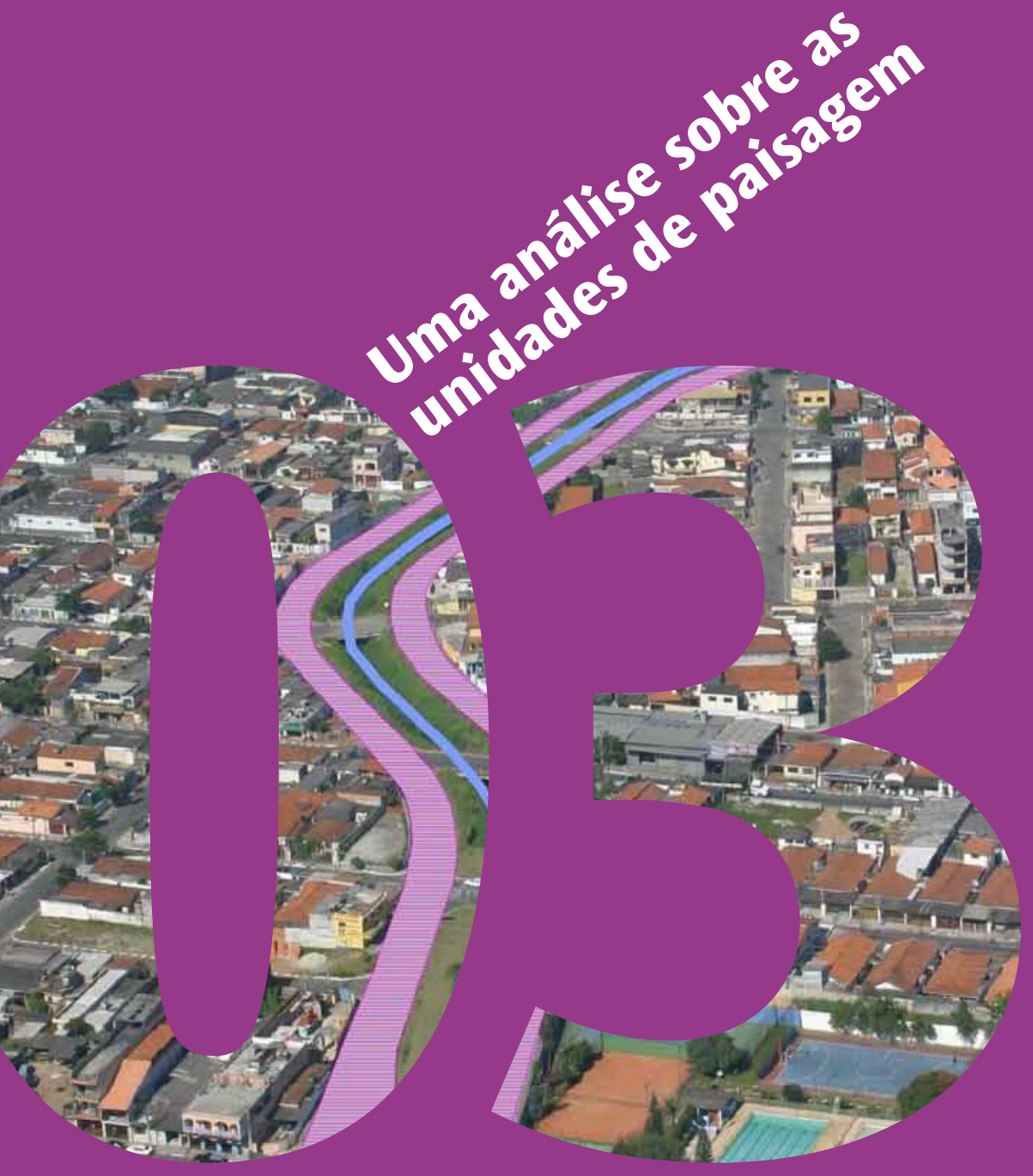





\section{Uma análise sobre as unidades de paisagem}

Para que as reflexões vinculadas às questões urbanísticas, paisagísticas e ambientais sejam aprofundadas, o território foi subdividido em 10 unidades de paisagem, utilizando-se da similaridade e uniformidade com relação ao uso e ocupação do solo como critério para a subdivisão das unidades. Estas foram analisadas pelo viés de suas características, conflitos, previsão com relação aos cenários futuros possíveis, além do levantamento das principais ações públicas executadas entre os anos de 2005 a 2011.

Para tanto, compreende-se por conflito "uma situação indesejável, ocasionada pelas formas de ocupação e apropriação dos recursos socioeconômicos e ambientais de um território, resultando em problemas sociais e/ou ambientais nesse espaço. Os conflitos são originados dos diversos processos de ocupação dos espaços e uso dos recursos"l.

Como cenário entende-se a possibilidade de futuras ações positivas ou negativas, com relação a um determinado aspecto acontecerem ou não, podendo ser este representado pela construção de um parque, ampliação das matas nativas existentes, limpeza dos corpos d'água, ou através da consolidação das ocupações irregulares, do depósito de resíduos em lugares inadequados entre outros.
I PROJETO ORLA: Manual de gestão. Brasília: MMA/SQA; Brasília: MP/SPU, 2002. p. 56 


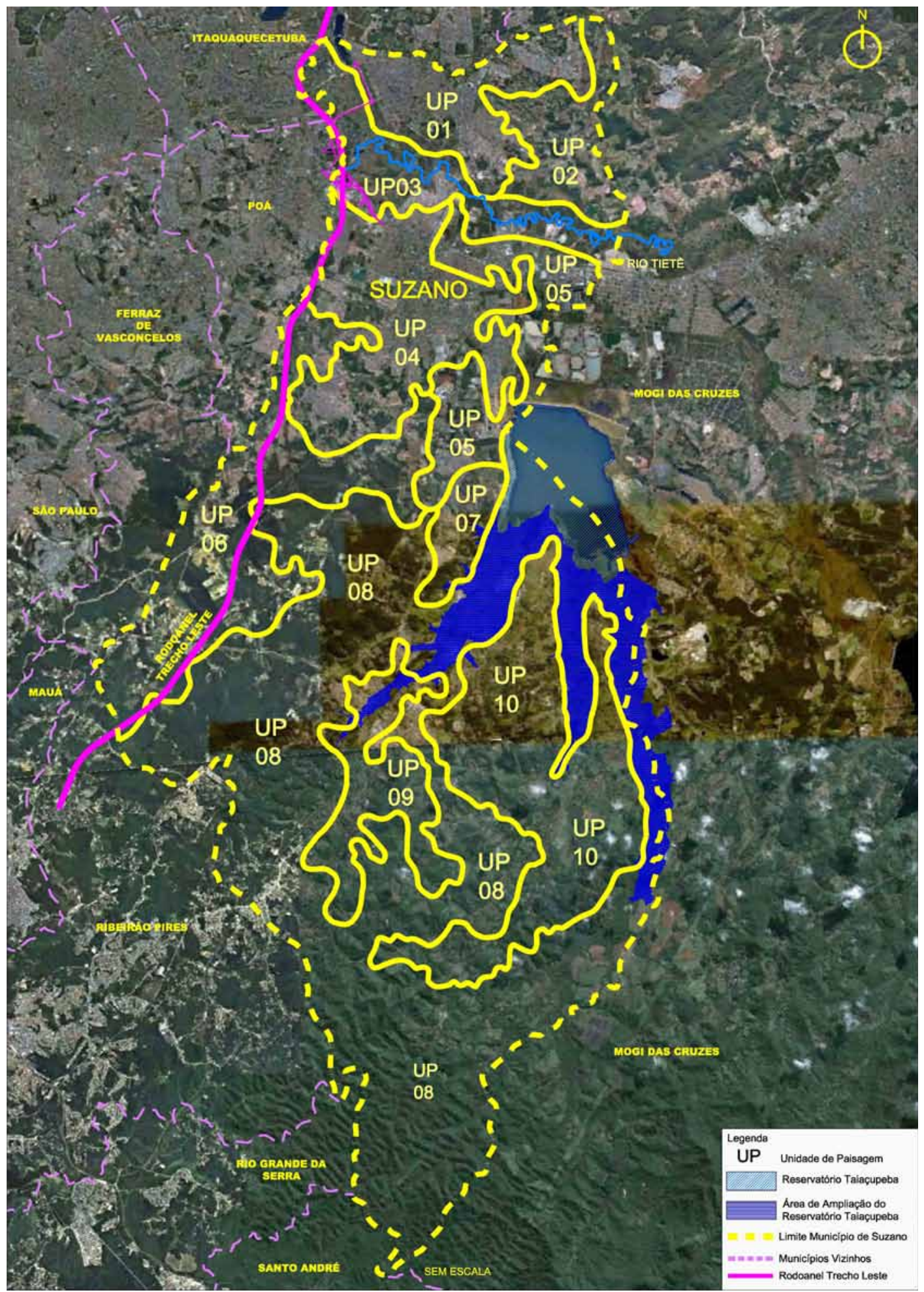

Mapa criado por Michele de Sá Vieira e Sanderlei Fernandes Vilanova (2011), a partir de imagens do Google, acessadas em dezembro de 2011 
Unidades de Paisagem: Uso e Ocupação do Solo

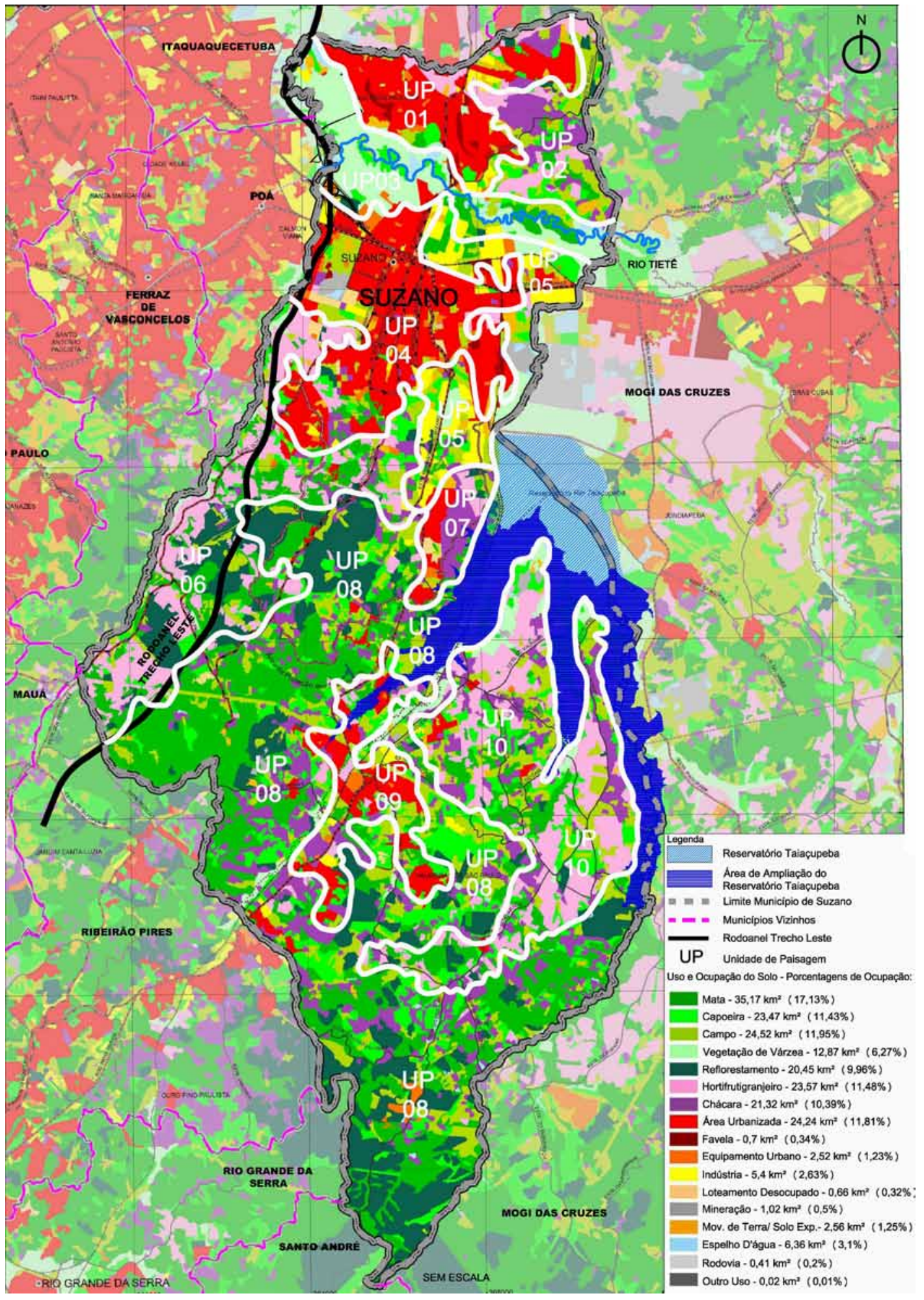

Mapa criado por Michele de Sá Vieira e Sanderlei Fernandes Vilanova (2011), a partir do mapa de Uso e Ocupação do Solo da Empresa Paulista de Planejamento Metropolitano SA - EMPLASA, 2006 


\section{Unidades de paisagens}

\section{Unidade de Paisagem 01}

\section{Características}

Possui urbanização consolidada e alta multiplicidade de usos,

\section{Suzano - Unidade de Paisagem 01}

Fonte: Mapa criado por Michele de Sá Vieira e Sanderlei Fernandes Vilanova (2012), a partir de mapa aerofotogramétrico da Prefeitura Municipal de Suzano, 2008 implantados em parte sobre relevo plano, mas também inclinado, tem como característica principal, no que se refere ao uso e ocupação do solo, muitos loteamentos altamente ocupados, além de indústrias, plantações de hortifrutigranjeiros, chácaras, fragmento de mata nativa, capoeiras e campos.

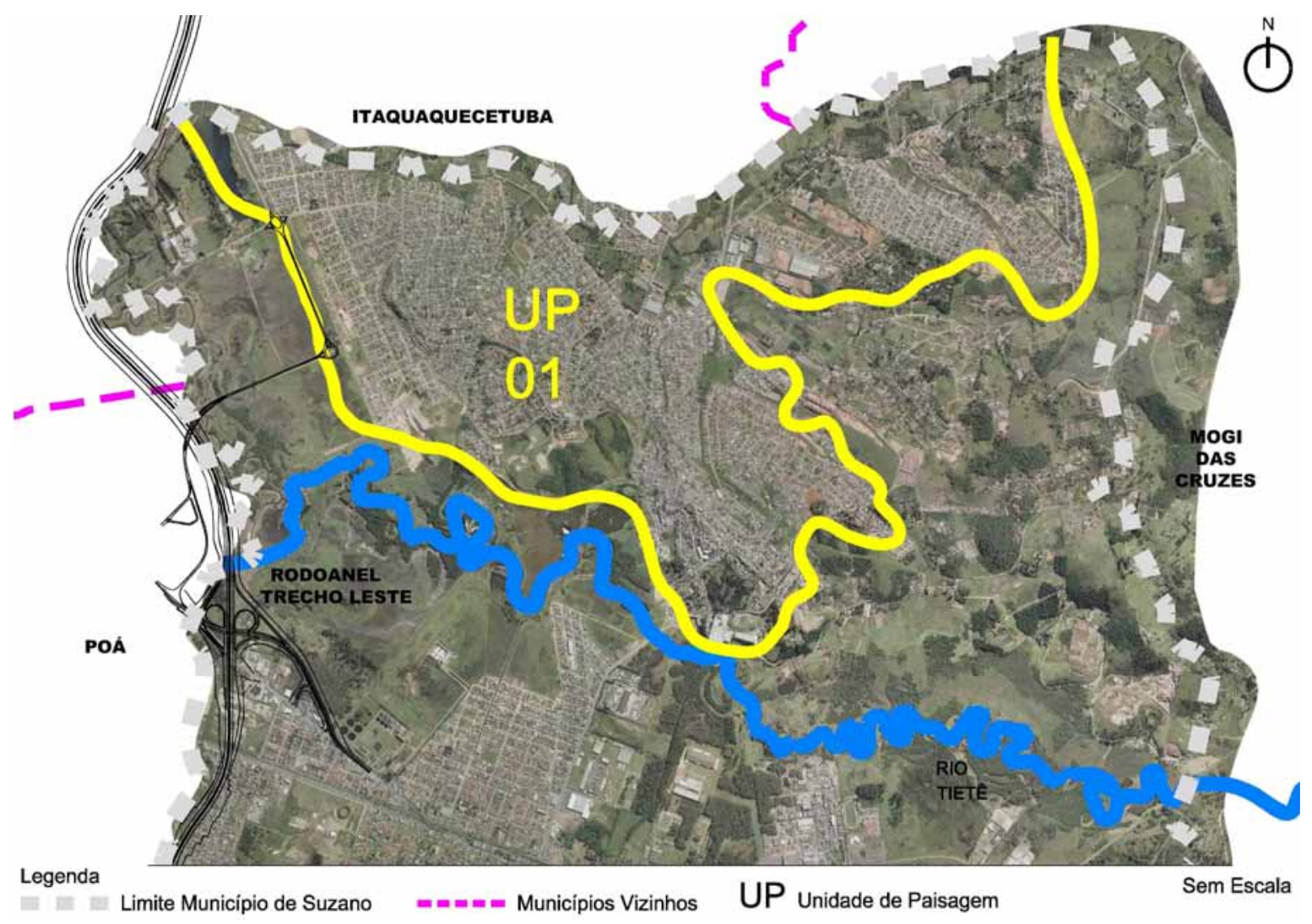




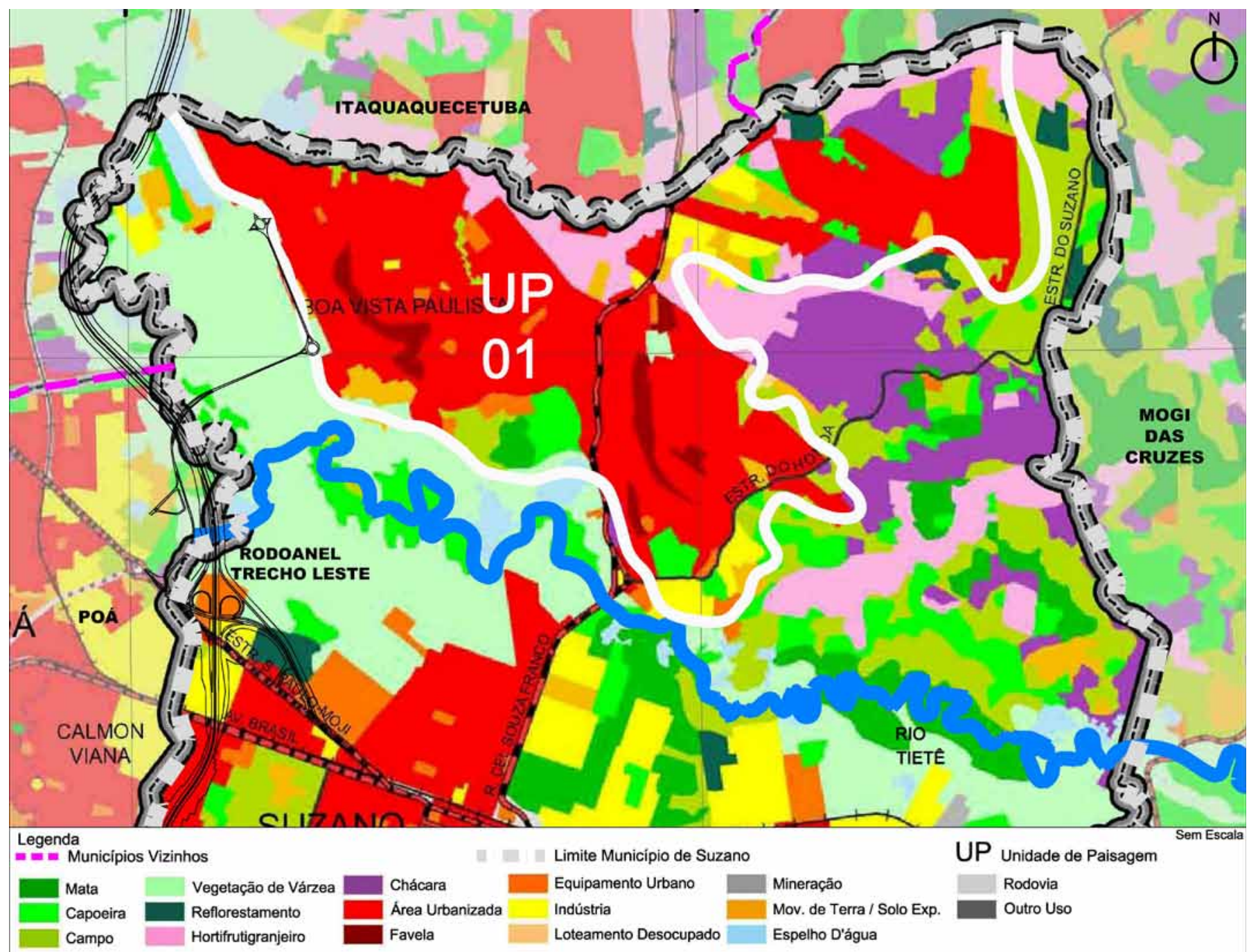

\section{Suzano - Unidade de Paisagem 01}

Fonte: Mapa criado por Michele de Sá Vieira e Sanderlei Fernandes Vilanova (2012), a partir do mapa do Uso e Ocupação do Solo da Empresa Paulista de Planejamento Metropolitano SA - EMPLASA, 2006 


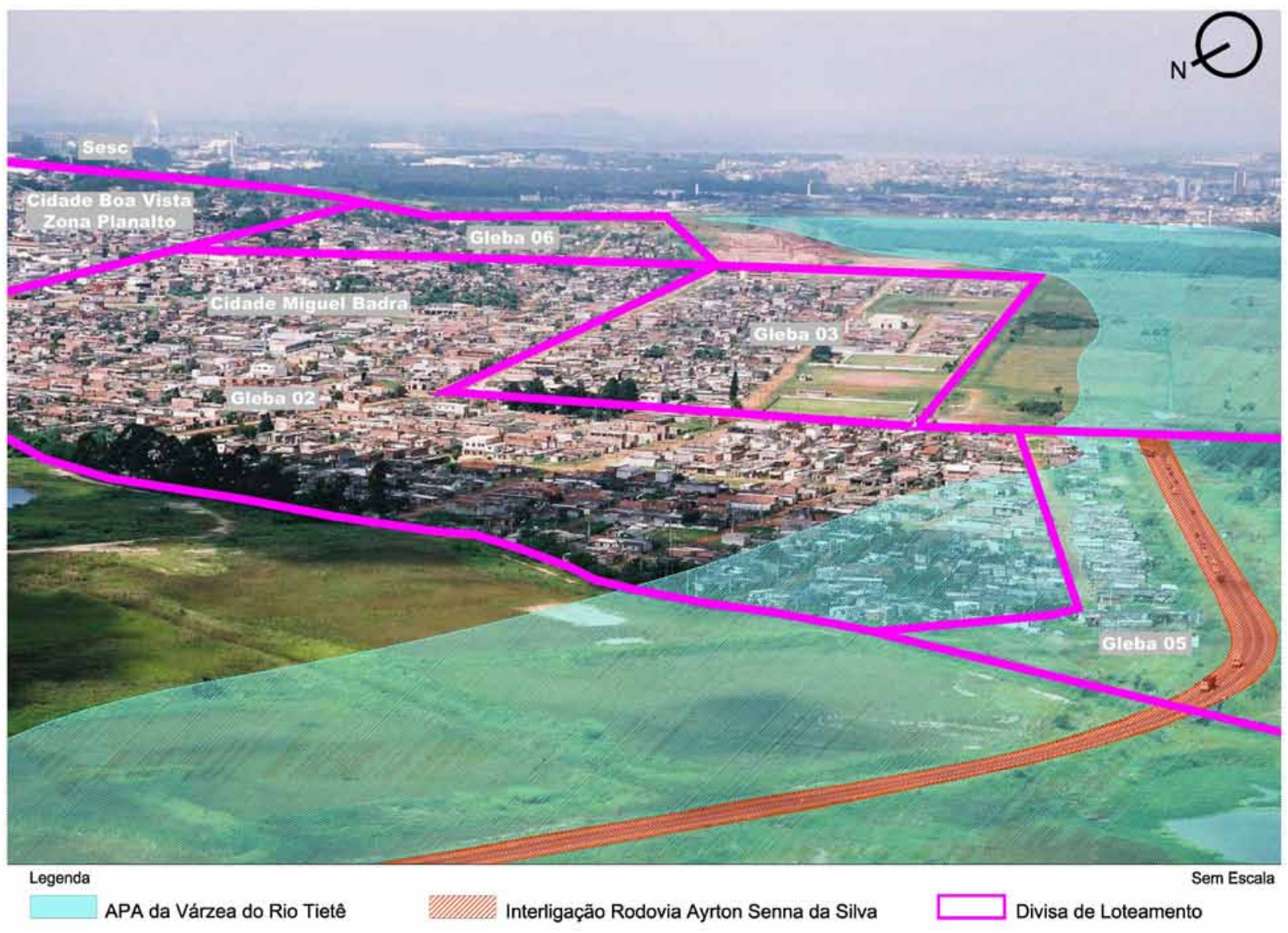

Suzano - Unidade de Paisagem 01. Loteamento Cidade Miguel Badra (Glebas 2, 3, 5 e 6), implantado próximo à Rodovia Ayrton Senna, sobre relevo praticamente plano, está altamente adensado por ocupações de baixa qualidade, as quais se inserem ao lado e também dentro da APA da várzea do Tietê. Porém, apesar desta localização, não possuem relação alguma vinculada com as atividades de lazer e recreação com este potencial ambiental que o território possui

Fonte: Prefeitura Municipal de Suzano, 2008 


\section{Conflitos}

Como conflito latente tem-se um intenso adensamento populacional, com paisagens altamente antropizadas e ocupações irregulares, que em parte estão em áreas de várzea, as quais são expressas por baixissima qualidade estética e urbanística, por promoverem fortes e agressivas transformações no suporte físico, erradicação total ou parcial de vegetação, arruamento em geral não planejado, excessiva ocupação dos lotes, ausência de calçamento e escassez de espaços livres públicos e privados tratados.

Existem ainda conflitos relacionados: a ausência da convivência da sociedade com um dos espaços livres mais significativos do território, que se trata da várzea do Tietê, as constantes movimentações de terra permitindo a exposição do solo, além das queimadas que acontecem por vezes no Parque Mirante do Tietê, provocadas muitas vezes pela própria população que vive em seu entorno. 


\section{Cenários futuros possíveis}

No que se refere aos cenários futuros possiveis positivos, a proximidade das ocupações junto à várzea do Tietê pode possibilitar ampla convivência da população com esta área, a partir da implementação do Parque Várzeas do Tietê que é, sem dúvida, uma das grandes oportunidades existentes no território com relação aos espaços livres.

Apesar dos inúmeros conflitos existentes esta unidade de paisagem possui qualidades para se desenvolver de forma a ter seus espaços transformados positivamente, no que se refere aos aspectos urbanisticos e ambientais.

Uma das oportunidades está vinculada aos canteiros centrais de algumas ruas, como a Edmilson Rodrigues Marcelino, que em função das suas amplas extensões, podem ser transformadas em ciclovias, além de abrigar espaços de lazer, bem-estar e arborização urbana.

Além disso, outras áreas existem com potencial para o uso público: como o rico sistema hídrico, capaz de abrigar parques lineares, a exemplo do córrego Jaguari e, também, as áreas de praças, que se forem tratadas podem atender as demandas da população e compor o sistema de espaços livres públicos.

0 Parque Mirante do Tietê, mais um grande potencial existente nesta unidade de paisagem, apesar de não possuir característica alguma voltada às atividades de parque, pode se tornar um excelente equipamento, por conter amplas áreas capazes de serem destinadas à instalação de equipamentos, vegetação nativa e proximidade com a várzea do Tietê. 
No entanto, ainda que este parque se apresente como um grande cenário futuro positivo, seu solo está bastante degradado, pois abriga intensa quantidade de entulho de residuos da construção civil, e a tendência é que este volume se amplie dado ao fato do local possuir extensas áreas com capacidade para receber um número maior de materiais desta natureza.

A consolidação das ocupações irregulares é outro fato presente nesta unidade, pois em função de sua extensão e conformação, acabam por se tornar espaços suscetiveis à invasão para a criação de locais de moradia, pela população de baixa renda impossibilitada de alugar ou adquirir propriedades regulares, ocupando, dessa forma, estas áreas de maneira inadequada. 


\section{Unidade de Paisagem 02}

\section{Características}

Possui amplas e extensas propriedades de chácaras e hotifrutigranjeiros cercadas por áreas de campos, matas, capoeiras e reflorestamentos, sobre relevo que é em geral acidentado e que ainda apresenta alguns trechos planos.

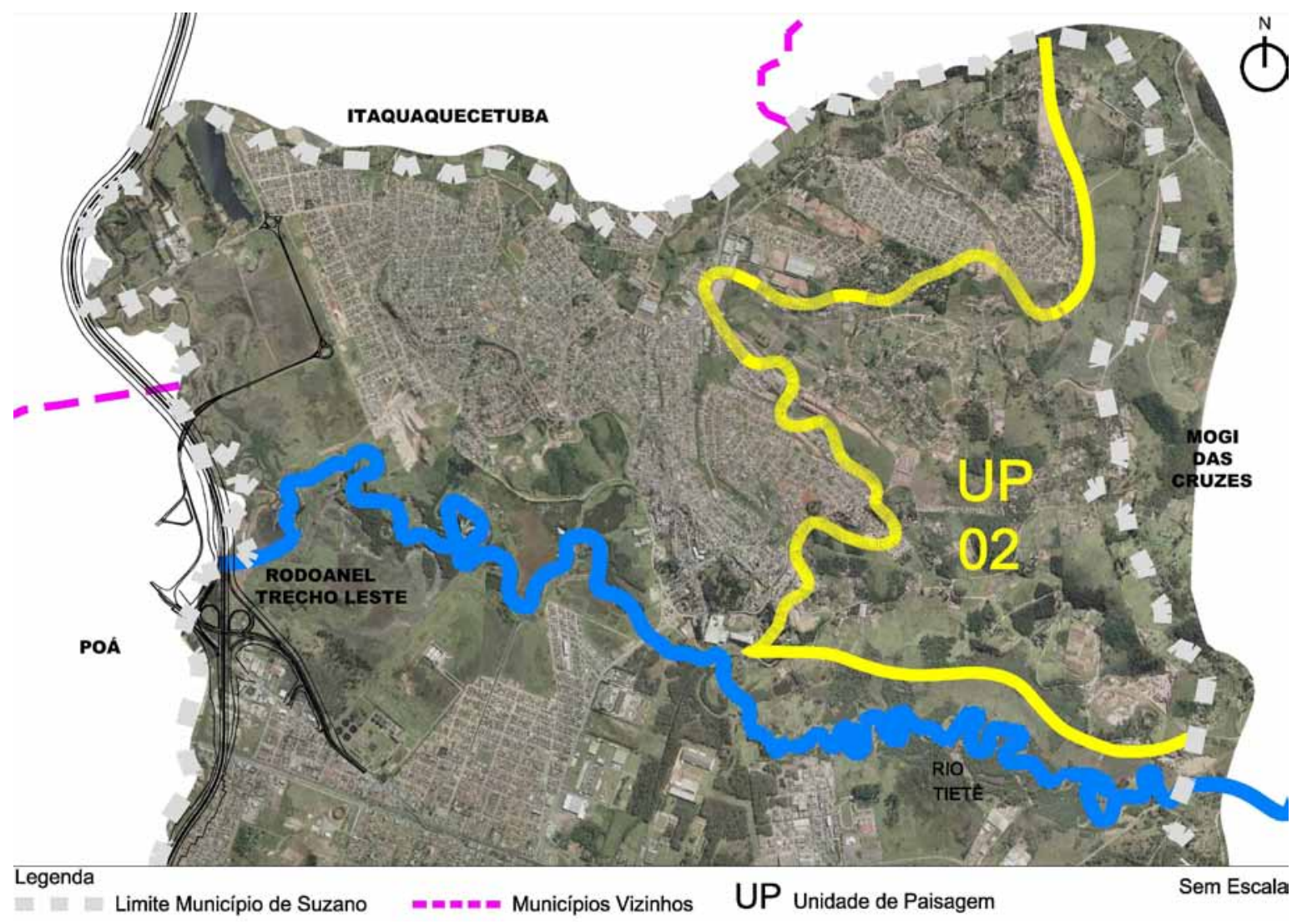

\section{Suzano - Unidade de Paisagem 02}

Fonte: Mapa criado por Michele de Sá Vieira e Sanderlei Fernandes Vilanova (2012), a partir de mapa aerofotogramétrico da Prefeitura Municipal de Suzano, 2008 


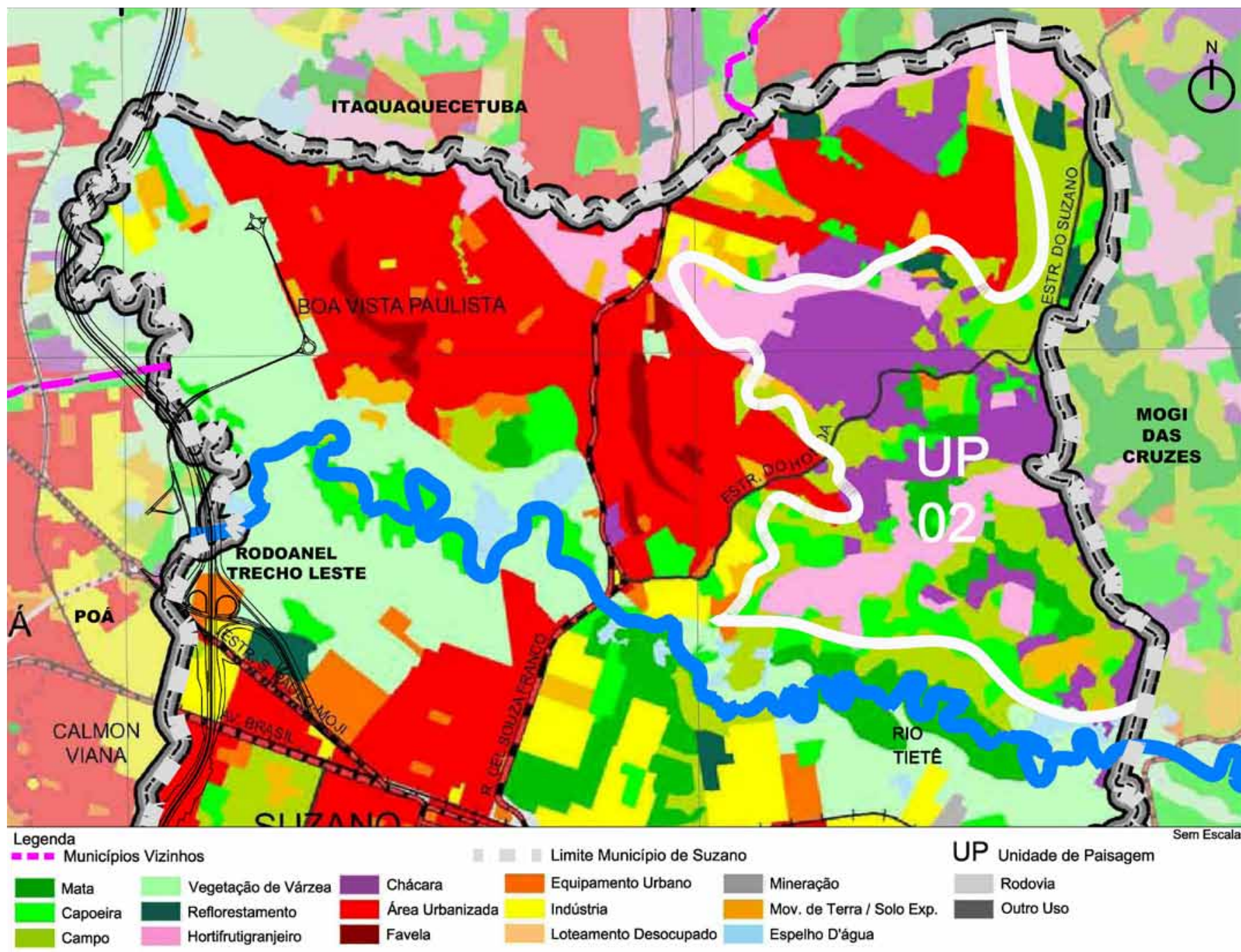

\section{Suzano - Unidade de Paisagem 02}

Fonte: Mapa criado por Michele de Sá Vieira e Sanderlei Fernandes Vilanova (2012), a partir do mapa do Uso e Ocupação do Solo da Empresa Paulista de Planejamento Metropolitano SA - EMPLASA, 2006 


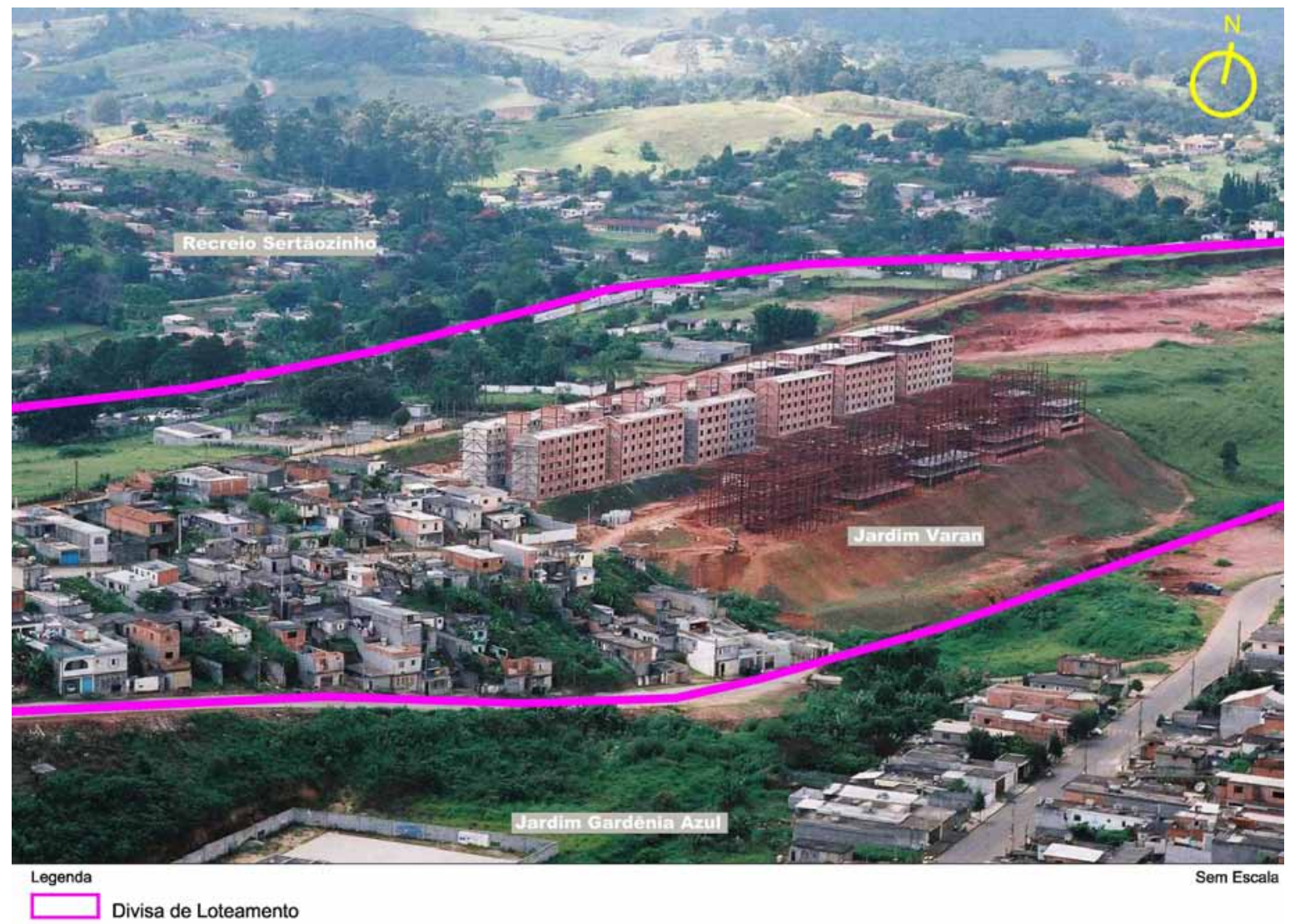

Suzano - Unidade de Paisagem 02. Nesta unidade de paisagem, a qual contém os loteamentos Recreio Sertãozinho, Jardim Varan e Jardim Gardênia Azul, observa-se o uso bastante diversificado do solo, através de ocupações unifamiliares precárias, unidades habitacionais, além de fragmentos de mata nativa preservados Fonte: Prefeitura Municipal de Suzano, 2008 - imagem organizada por Michele de Sá Vieira e Sanderlei Fernandes Vilanova, 2012

\section{Conflitos}

Assim como na Unidade de Paisagem 01, esta também possui movimentação de terra com solo exposto, exploração do sistema hídrico em função das atividades vinculadas à agricultura e baixa qualidade com relação aos aspectos urbanisticos. 


\section{Cenários futuros possiveis}

Como cenário futuro positivo tem-se a possibilidade desta unidade estabelecer duas conexões com vegetação nativa, através de corredores ecológicos, ou seja, uma com a serra do Itapety, localizada no município de Mogi das Cruzes, e a outra com a várzea do rio Tietê.

A conexão com a serra do Itapety pode ser facilitada em função de dois aspectos:

- $\quad$ primeiro pelo o fato da serra estar bastante próxima do municipio de Suzano;

- $\quad$ segundo em função deste território possuir, na Unidade de Paisagem 02, muitas áreas de campo e capoeira que podem ser reflorestadas, constituindo-se, portanto, em corredores ecológicos, com capacidade de promover conexões com a serra.

Já com a várzea do Tietê a possibilidade se dá em razão:

- da proximidade com a própria várzea;

- dos inúmeros fragmentos existentes tanto na várzea, quanto na Unidade de Paisagem 02.

Como cenário futuro negativo, a consolidação das ocupações irregulares é uma questão presente nesta unidade, assim como na unidade anterior, em função do preço da terra ser conveniente à população que apresenta baixa renda. 


\section{Unidade de Paisagem 03}

\section{Características}

É constituída em 2012, pela APA da várzea do rio Tietê. Instalada em relevo plano possui alto potencial estético, e embora esta paisagem esteja parcialmente antropizada, trata-se de uma área de expressivo interesse ecológico, ambiental e paisagístico, a qual possui meandros bem preservados conjuntamente com os fragmentos de mata nativa, além de áreas cobertas por campo e capoeira.

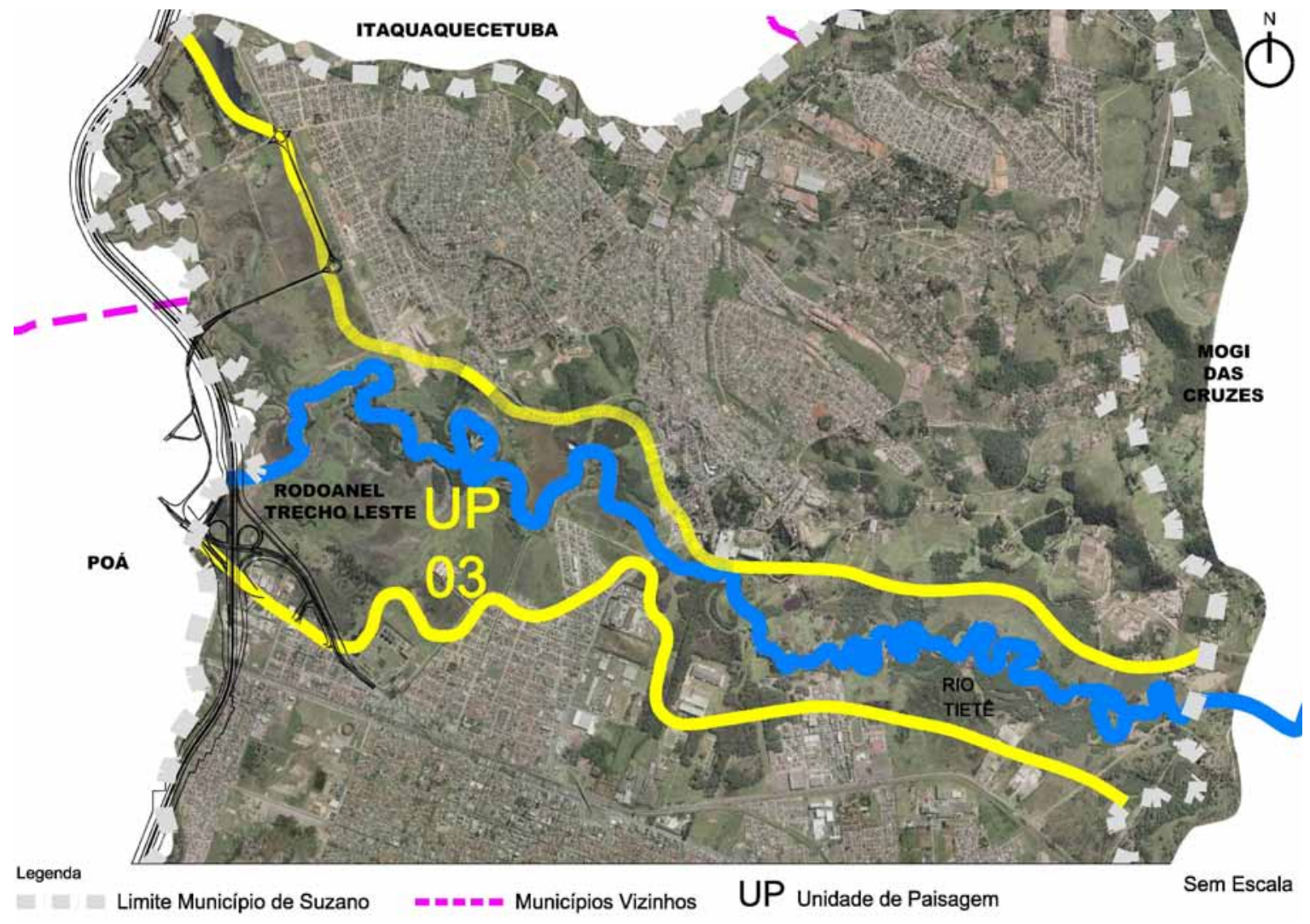

Suzano - Unidade de Paisagem 03

Fonte: Mapa criado por Michele de Sá Vieira e Sanderlei Fernandes Vilanova (2012), a partir de mapa aerofotogramétrico da Prefeitura Municipal de Suzano, 2008 


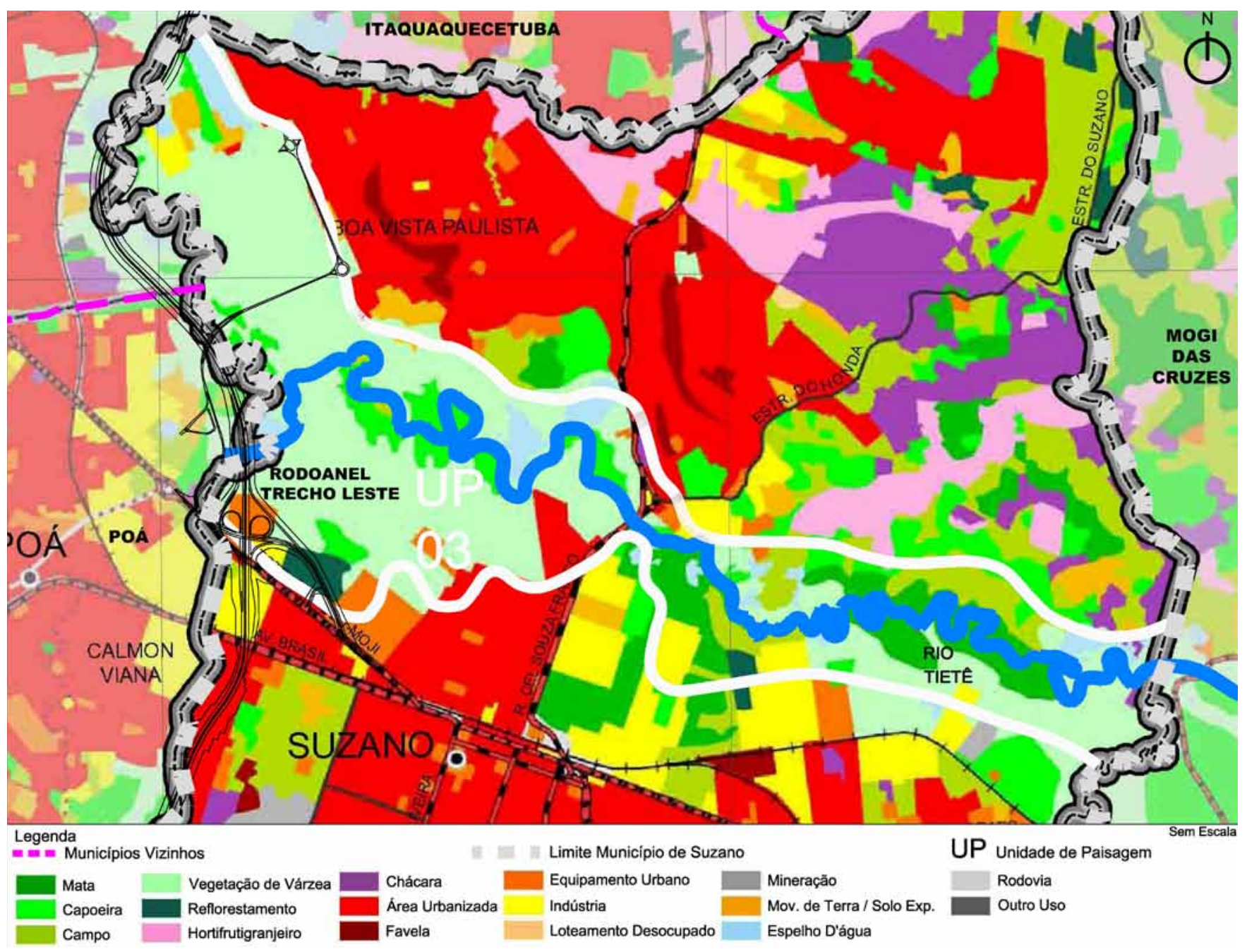

\section{Suzano - Unidade de Paisagem 03}

Fonte: Mapa criado por Michele de Sá Vieira e Sanderlei Fernandes Vilanova (2012), a partir do mapa do Uso e Ocupação do Solo da Empresa Paulista de Planejamento Metropolitano SA - EMPLASA , 2006 


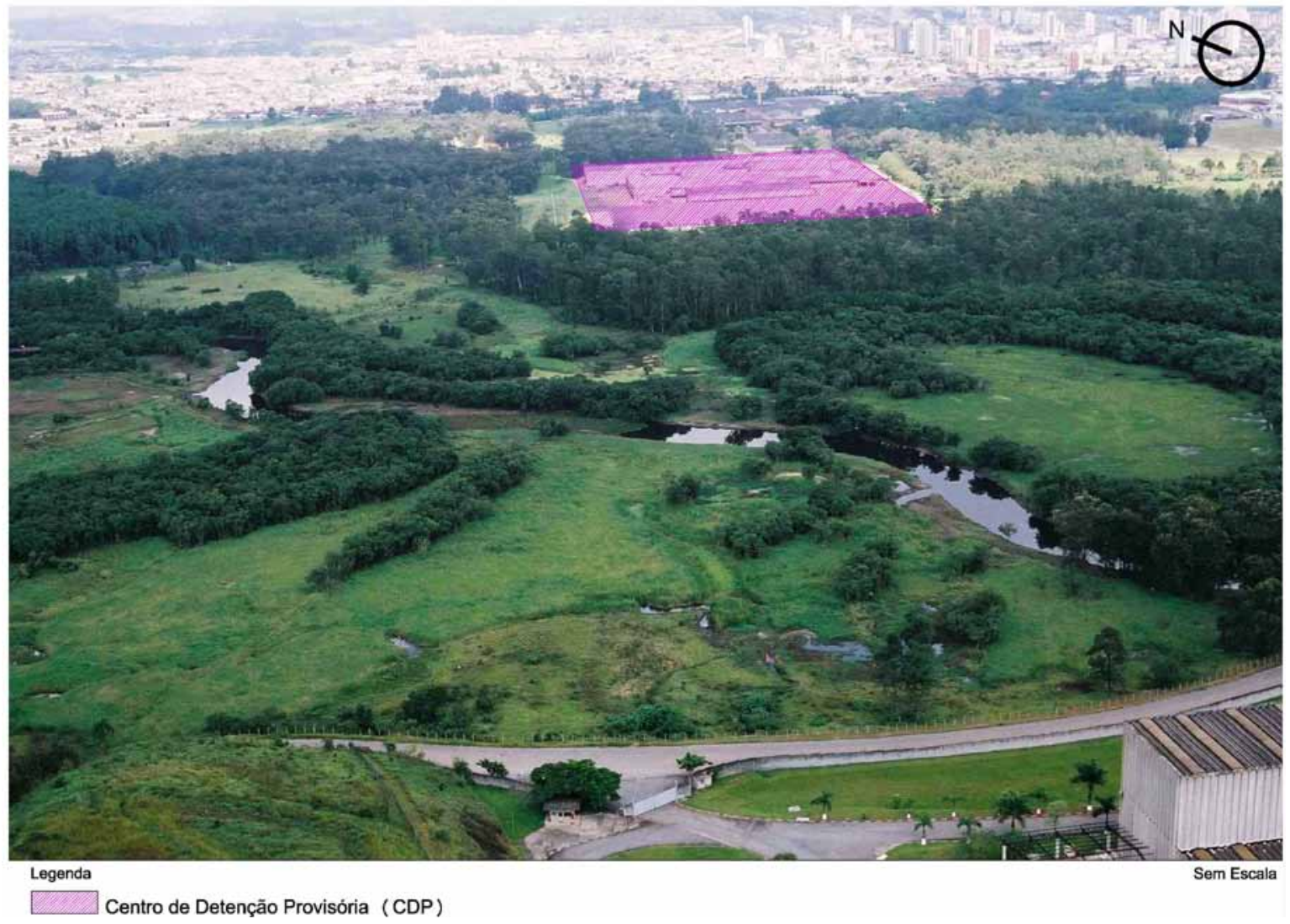

Suzano - Unidade de Paisagem 03. A beleza cênica da APA da Várzea do Tietê é evidente, no entanto, ações antrópicas como a instalação do Centro de Detenção Provisória (CDP) comprometem a estética da sua paisagem, bem como a integridade física do seu ambiente Fonte: Prefeitura Municipal de Suzano, 2008 - imagem organizada por Michele de Sá Vieira e Sanderlei Fernandes Vilanova, 2012

\section{Conflitos}

Ainda que esta unidade de paisagem possua um intenso potencial paisagístico, ambiental e ecológico, nela estão assentados equipamentos industriais e o Centro de Detenção Provisória (CDP), além de outras atividades já licenciadas com previsão de exploração, vinculadas à extração mineral com concessão de lavra, argila e cascalho.

Entre todas as ações conflitantes existentes nesta Unidade 03, a mais significativa refere-se ao fato de alguns loteamentos como a Vila Maluf se situarem sobre a área da várzea, sofrendo por isso várias inundações. 


\section{Cenários futuros possíveis}

A implantação do Parque Várzeas do Tietê, com alto potencial cênico, prevista pelo governo do Estado, é sem dúvida o grande cenário futuro positivo a ser efetivado. Caso realmente aconteça, esta iniciativa, além de definir o uso adequado ao espaço, irá oferecer possibilidades de convivência da população com a paisagem desta unidade.

Como cenário negativo, observa-se que caso o Parque Várzeas não seja implantado, a tendência é que ocorra a extinção dos fragmentos de mata nativa, em função das constantes ações antrópicas. Além disso, a ampliação total ou parcial de empreendimentos vinculados à indústria a serem construídas irão contribuir significativamente para com a ampliação da impermeabilização do solo.

Com relação às águas, a não execução de medidas voltadas ao tratamento de esgotos por parte da SABESP, tendem a permitir a ampliação da poluição sanitária.

Para além das questões conflitantes já instaladas, tem-se a previsão da implantação da alça do Rodoanel Leste, que irá ser construída sobre a várzea do Tietê. 


\section{Unidade de Paisagem 04}

\section{Características}

Possui ocupações urbanas consolidadas, situadas sobre relevo principalmente plano, servidas de infraestrutura, com relação ao saneamento básico, iluminação, pavimentação, transporte, espaços livres com usos definidos, além de equipamentos urbanos voltados à educação e saúde, entre outros.

\section{Suzano - Unidade de Paisagem 04}

Fonte: Mapa criado por Michele de Sá Vieira e Sanderlei Fernandes Vilanova (2012), a partir de mapa aerofotogramétrico da Prefeitura Municipal de Suzano, 2008

De maneira menos preponderante, no que se refere ao uso e a ocupação do solo, esta unidade de paisagem possui loteamentos desocupados, espaços destinados à indústria, áreas de campos, capoeiras, matas, chácaras e cultivo de hortifrutigranjeiros.

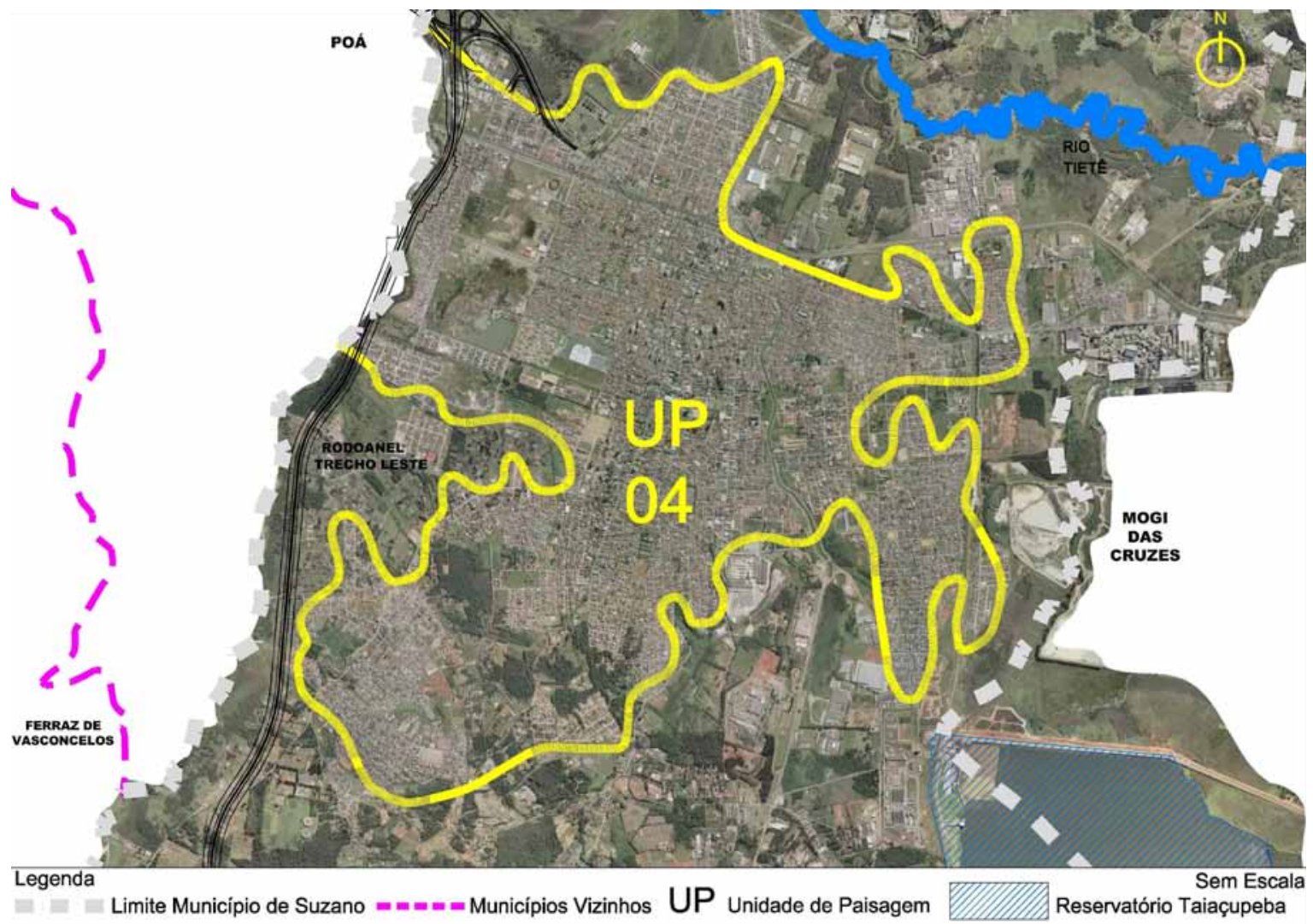




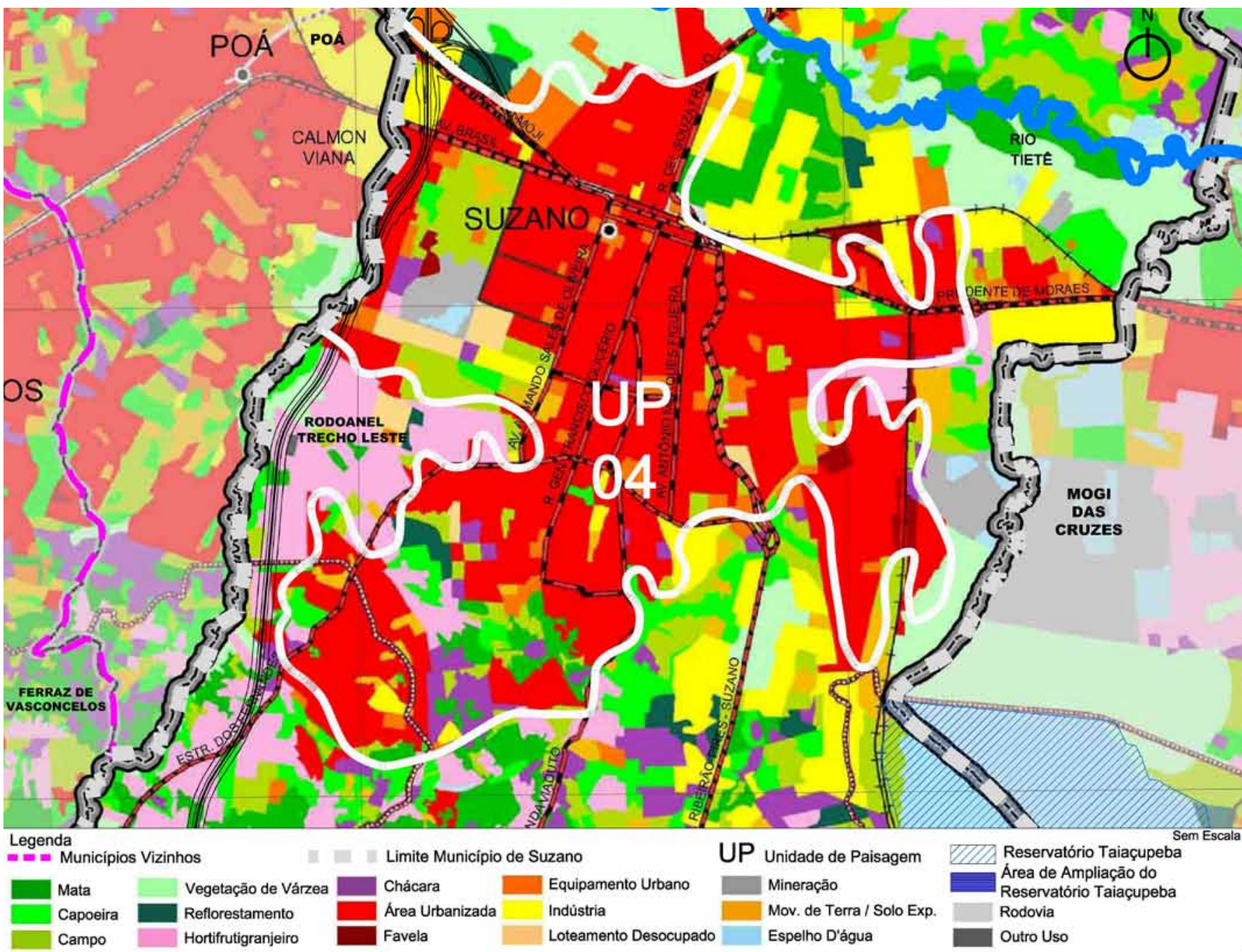

\section{Suzano - Unidade de Paisagem 04}

Fonte: Mapa criado por Michele de Sá Vieira e Sanderlei Fernandes Vilanova (2012), a partir do mapa do Uso e Ocupação do Solo da Empresa Paulista de Planejamento Metropolitano SA - EMPLASA, 2006 
Suzano - Unidade de Paisagem 04. A consolidação das ocupações urbanas com boa infraestrutura é a característica principal desta unidade, pois os locais são pavimentados e iluminados, além de possuírem espaços livres públicos com manutenção adequada, como se observa na área remanescente entre o córrego Chico da Vargem (rio Una) e a Avenida Governador Mário Covas Jr. Fonte: Prefeitura Municipal de Suzano, 2008 - imagem organizada por Michele de Sá Vieira e Sanderlei Fernandes Vilanova, 2012

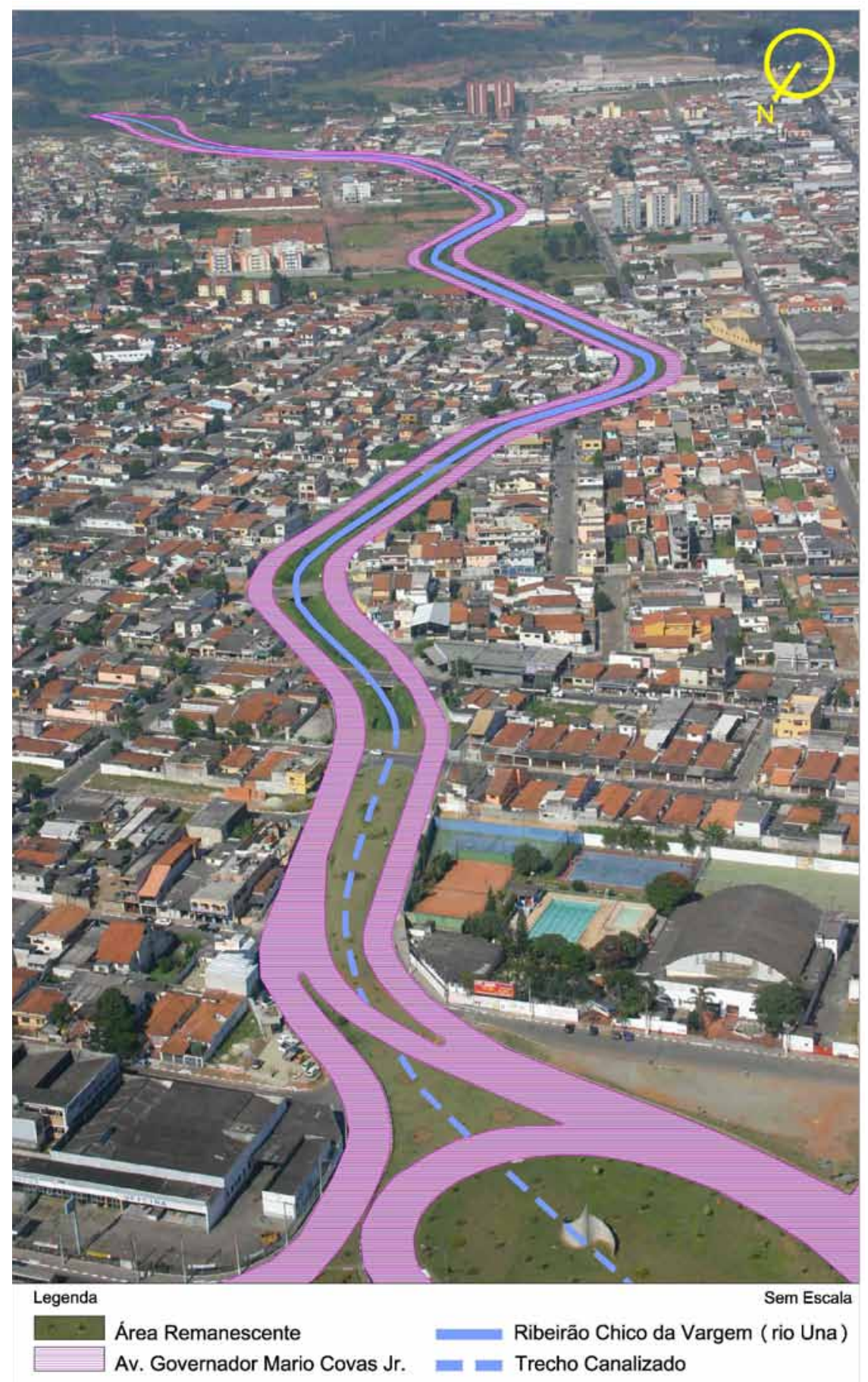




\section{Conflitos}

A exploração imobiliária latente, sem dúvida, contribuiu imensamente para os conflitos que foram sendo cada vez mais enfáticos ao longo dos anos, nesta unidade de paisagem. Pois, quando associamos as altas taxas de ocupação provenientes desta exploração, que geram impermeabilização do solo, ao sistema de drenagem público deficiente, temos como resultado as constantes enchentes no período de chuvas em determinados espaços desta região.

Além disso, outras questões são apontadas como conflitos:

- as calçadas inadequadas, por possuírem dimensões insuficientes, revestimentos danificados, ausência de pisos táteis que facilitam a mobilidade dos deficientes visuais, inexistência de rampas para as pessoas de mobilidade reduzida e arborização com raízes agressivas, as quais dificultam e, até mesmo, impedem o trânsito dos pedestres;

- a poluição visual das fachadas do comércio, que se encontram deterioradas por falta de manutenção por parte dos comerciantes, prejudicam a estética do centro comercial da cidade.

\section{Cenários futuros possíveis}

Como potencialidade positiva, apesar de diversas calçadas possuirem dimensões reduzidas, ainda assim existem muitas possibilidades para que a arborização urbana seja implementada na Unidade de Paisagem 04, favorecendo esteticamente os espaços, além de contribuir para a regulação climática².
2 Como exemplo, tem-se a Parada Tiradentes, implantada como projeto-piloto em 2005 (vide Capítulo 01 página 64), a qual promoveu diversas alterações que beneficiaram o espaço onde a intervenção aconteceu, no que se refere aos aspectos urbanísticos, paisagísticos e ambientais, dado a: inserção de pisos permeáveis, implementação de pisos táteis, rampas de acessibilidade, canteiro ajardinado junto às guias, inserção de espécies arbóreas e ornamentais, além do ponto de ônibus capaz de atender as demandas da população. 
${ }^{3} 0$ termo infraestrutura verde é entendido como "um conjunto de ferramentas que visa utilizar os recursos naturais a favor das cidades como, por exemplo, a redução das ilhas de calor e o melhor aproveitamento da água. Essas iniciativas são classificadas em quatro grupos: preservação da vegetação, criação de espaços de convivência, instalação de ciclovias e de trilhas para pedestres, drenagem natural com filtragem e aproveitamento das águas da chuva”. Disponível em: < http://www.urbansystems.com.br/ noticias/ler/imoveis-cdhu-promove-oficina-sobre-infra-estrutura-verde >. Acesso em: 6 fev. 2012.
Para que cenários futuros com qualidade urbanistica e paisagística aconteçam, projetos voltados à implementação de infraestrutura verde, devem estar entre os objetivos da gestão pública ${ }^{3}$.

A implementação de fragmentos florestais lineares, também, é outra ação possivel para a região, considerando-se que há áreas remanescentes, nesta unidade, capazes de receber diversas espécies de arborização. Um exemplo deste tipo de local está ao longo do Córrego Chico da Vargem (Rio Una), que possui espaços a serem utilizados, tanto junto ao curso d'água, quanto nos seus arredores, os quais podem ser incorporados a um grande desenho, com usos diversos, voltados ao lazer e à recreação.

A requalificação de algumas praças existentes, através da inserção de novas espécies, novo mobiliário urbano e estímulo ao uso, com atividades culturais de lazer e recreação, também é uma ação possivel para a potencialização dos espaços livres públicos na unidade.

Os principais eixos, como as ruas Francisco General Glicério e Benjamin Constant, oferecem oportunidades para serem fechadas e transformadas em calçadões capazes de conter arborização urbana, mobiliário urbano e iluminação, ou seja, ações que levem o cidadão aos espaços externos, abertos, incentivando dessa maneira as atividades vinculadas ao comércio e ao lazer. 


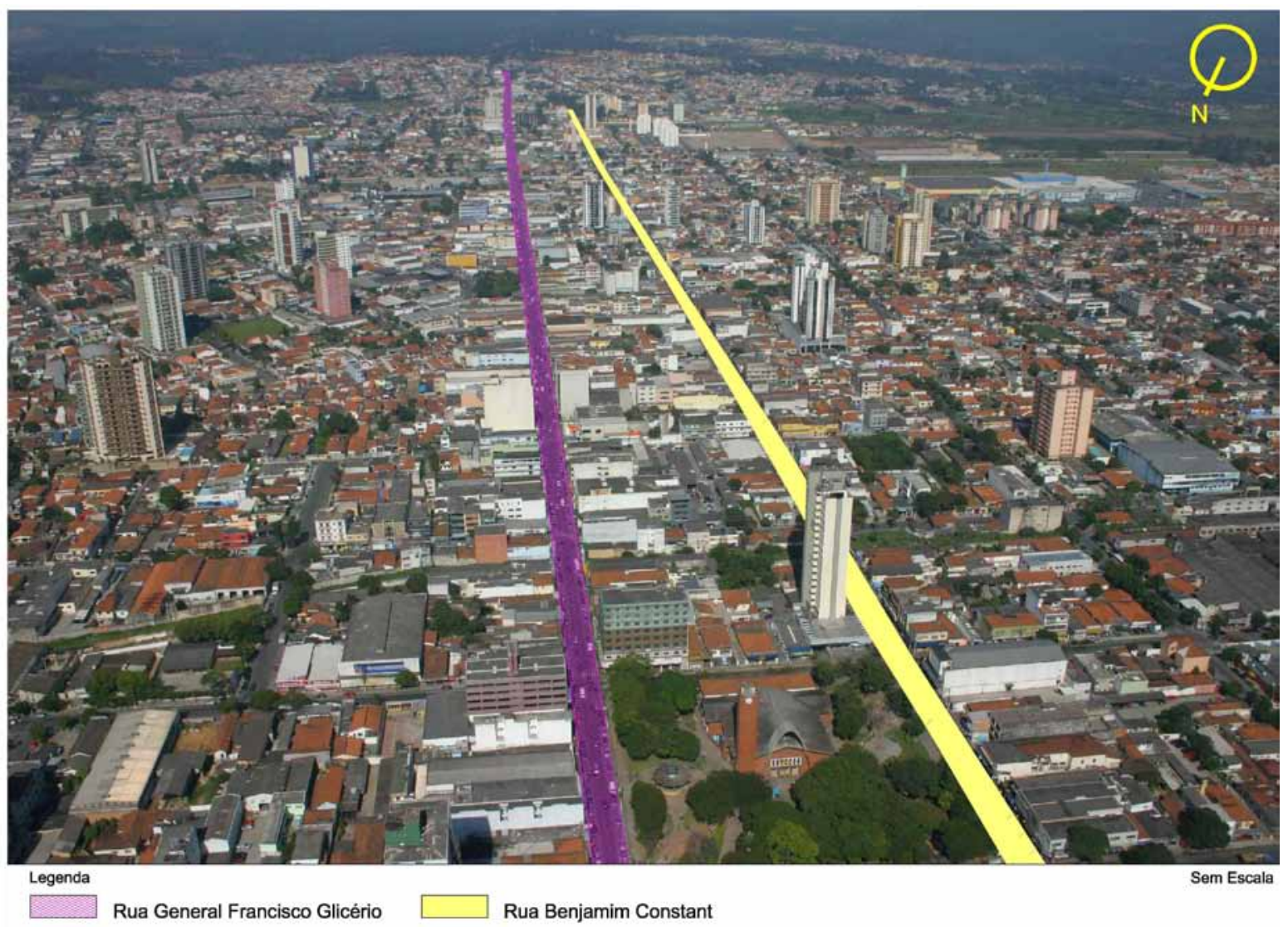

Suzano - Unidade de Paisagem 04. As ruas Francisco General Glicério e Benjamin Constant possuem comércio diversificado por conterem ao longo de seu percurso inúmeros bancos, farmácias, lanchonetes, restaurantes, além de lojas de eletrodomésticos, roupas, calçados, móveis, perfumaria, materiais de construção, entre outras. Em função disso, bem como por serem eixos que promovem importantes interligações na região central, acabam atraindo inúmeros pedestres no seu cotidiano

Fonte: Prefeitura Municipal de Suzano, 2008 - imagem organizada por Michele de Sá Vieira e Sanderlei Fernandes Vilanova, 2012

Próximo ao Parque Max Feffer, encontram-se as instalações do Instituto Federal de Educação, Ciência e Tecnologia de São Paulo (IFSP) e da Universidade Piaget (Unipiaget), os quais vão potencializar a região como um importante polo educacional. Ambos possuem amplos espaços livres, que terão quadras de esporte entre outros equipamentos. No caso em específico da Unipiaget, 
será incorporado, especialmente, uma lagoa que antes era utilizada como cava de mineração, além de pista de corrida, ciclovia, quiosques e intenso plantio de espécies arbóreas, incrementando, dessa forma, o sistema de espaços livres do território.

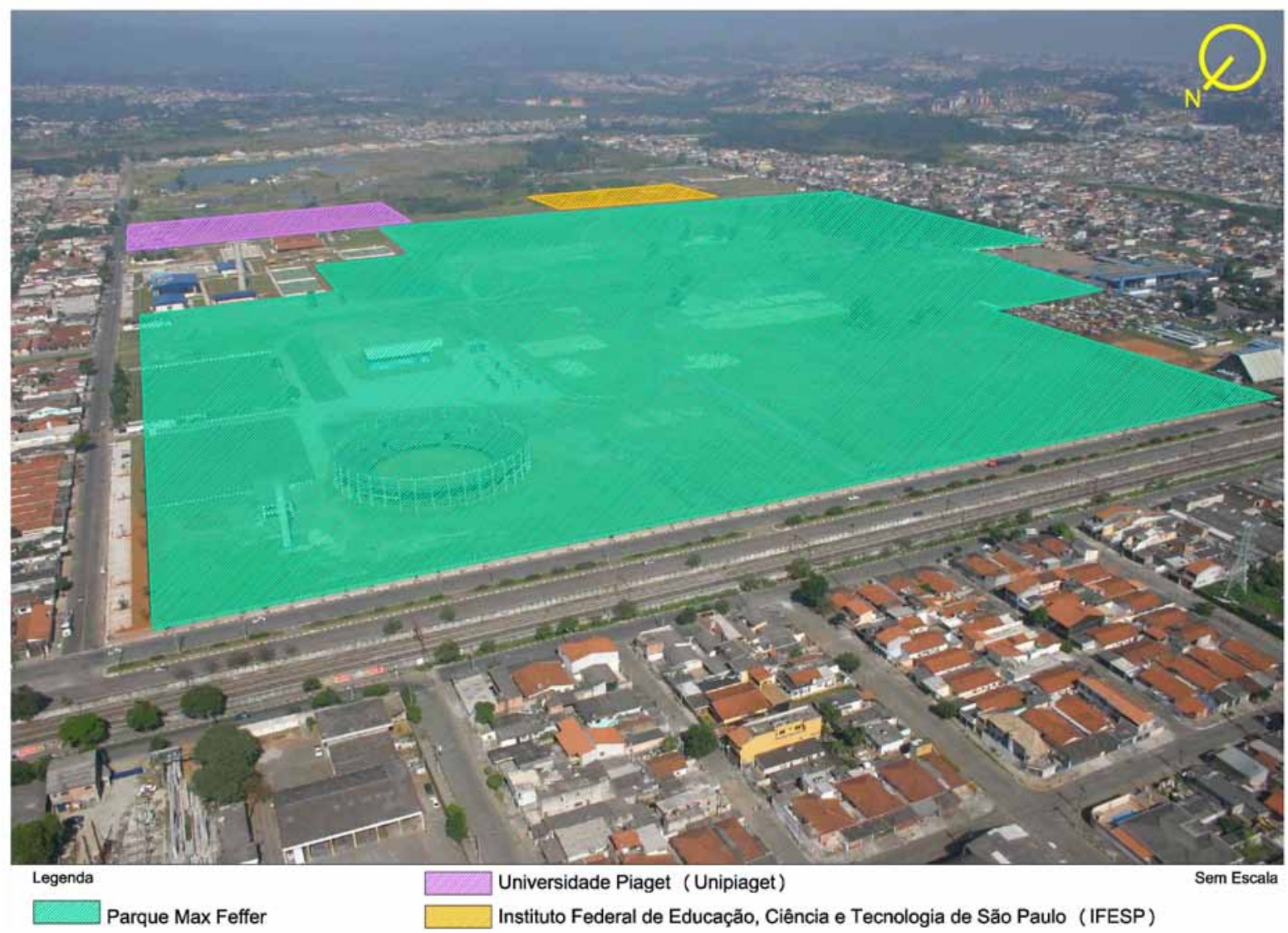

Suzano - Unidade de Paisagem 04. A consolidação do Instituto Federal de Educação, Ciência e Tecnologia de São Paulo (IFSP) e da Universidade Piaget (Unipiaget), os quais já se encontram edificados e com perspectivas de ampliação, somados à potencialização do Parque Max Feffer, que vem recebendo inúmeras obras, tais como: 0 pavilhão de cultura afro, a concha acústica, o pavilhão de esportes, a reforma da piscina, bem como as obras em andamento da arena multiuso e da praça de apoio ao turista, sem dúvida, trazem inúmeros benefícios para esta área, a qual já se encontra consolidada por ocupações urbanas servidas com boa infraestrutura como o transporte, saneamento, iluminação, pavimentação, entre outras

Fonte: Prefeitura Municipal de Suzano, 2008 - imagem organizada por Michele de Sá Vieira e Sanderlei Fernandes Vilanova, 2012 
Como cenário futuro negativo observa-se que, mediante as inúmeras retiradas da vegetação arbórea da região central, somada à ausência de reposição com novos indivíduos, isso tende a comprometer este setor, no que se refere à temperatura e à estética local ${ }^{4}$.

A dificuldade quanto à acessibilidade é outro fato negativo, dada a existência de calçadas estreitas, que se soma à falta de iniciativas privadas, com relação à manutenção destas, no que se refere, por exemplo, a recuperação dos seus revestimentos ${ }^{5}$.
${ }^{4}$ As espécies inseridas na região central possuem raízes muito agressivas, as quais danificam as calçadas oferecendo riscos na circulação dos pedestres.

5 A Lei Complementar n. 025/96, a qual (dispõe sobre a divisão do território do Município em Zonas de Uso, regula o parcelamento e a ocupação do solo, dispõe sobre os imóveis e as edificações em geral) coloca em seus anexos: Tabela "D" (que vias coletoras como as ruas Francisco General Glicério e Benjamin Constant) devem de acordo com a Tabela "B" (ter calçada com largura mínima de $2,50 \mathrm{~m}$ ), no entanto, em muitos locais elas possuem dimensões inferiores ao que está previsto na Lei. 
${ }^{6}$ A Suzano Papel e Celulose, maior contribuinte com relação a arrecadação orçamentária do município, conta com cinco unidades industriais: Suzano, Rio Verde, Embu e Americana, no estado de São Paulo, além da empresa em Mucuri no sul da Bahia. A Unidade Suzano possui cerca de 89.000 hectares de áreas florestadas com eucaliptos distribuídos em diferentes regiões no Estado de São Paulo, sendo que parte destas áreas está localizada no Vale do Paraíba e na Região Metropolitana de Campinas, além do Alto Tietê Cabeceiras, em Salesópolis e Suzano, na qual o espaço destinado a plantação de eucalipto é de aproximadamente 2.779,66 hectares. A técnica de manejo hoje (2012) utilizada pela empresa é do cultivo mínimo, a qual visa obter produtividade florestal com a racionalização operacional dentro do ciclo total.

\section{Unidade de Paisagem 05}

\section{Características}

Possui grande área industrial assentada sobre relevo praticamente plano, abrigando importantes empresas de grande porte como a Clariant S/A, Produquímica Indústria e Comércio Ltda., Agfa Graphics Brasil, Komatsu do Brasil, além da Suzano Papel e Celulose, maior empresa do município ${ }^{6}$.

A vegetação é abundante nesta unidade, a qual contém áreas de várzea próximas à Represa de Taiaçupeba, bem como campos, capoeiras e mata nativa, entremeados próximo às ocupações industriais.

\section{Suzano - Unidade de Paisagem 05}

Fonte: Mapa criado por Michele de Sá Vieira e Sanderlei Fernandes Vilanova (2012), a partir de \} mapa aerofotogramétrico ) da Prefeitura Municipal de Suzano, 2008

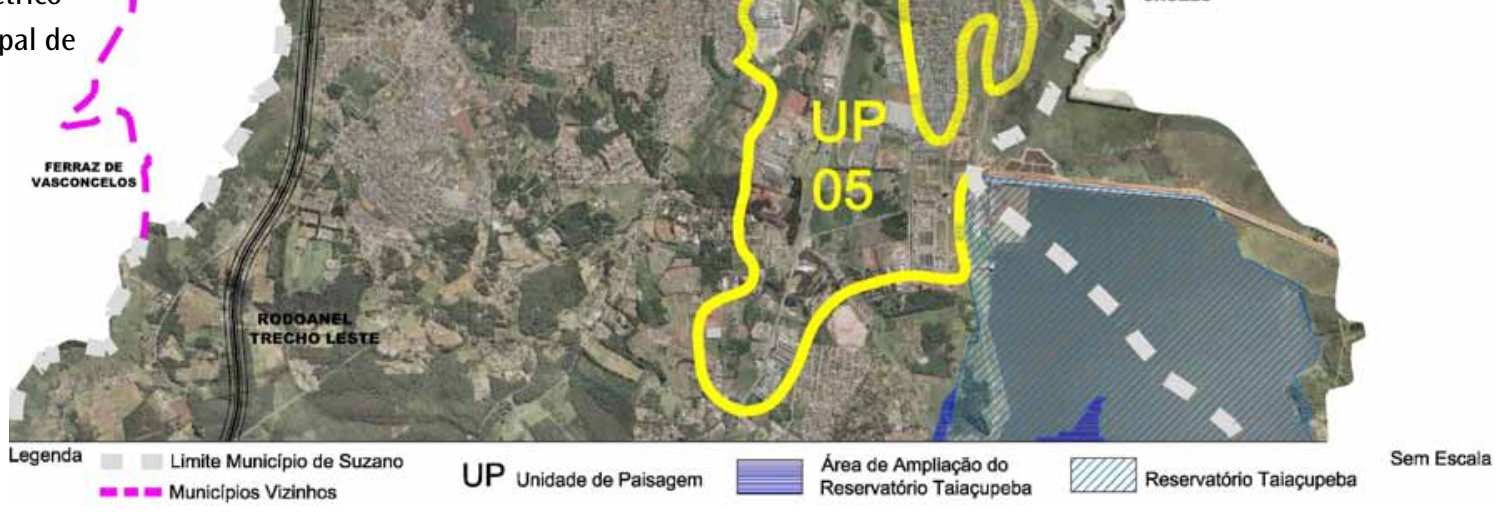




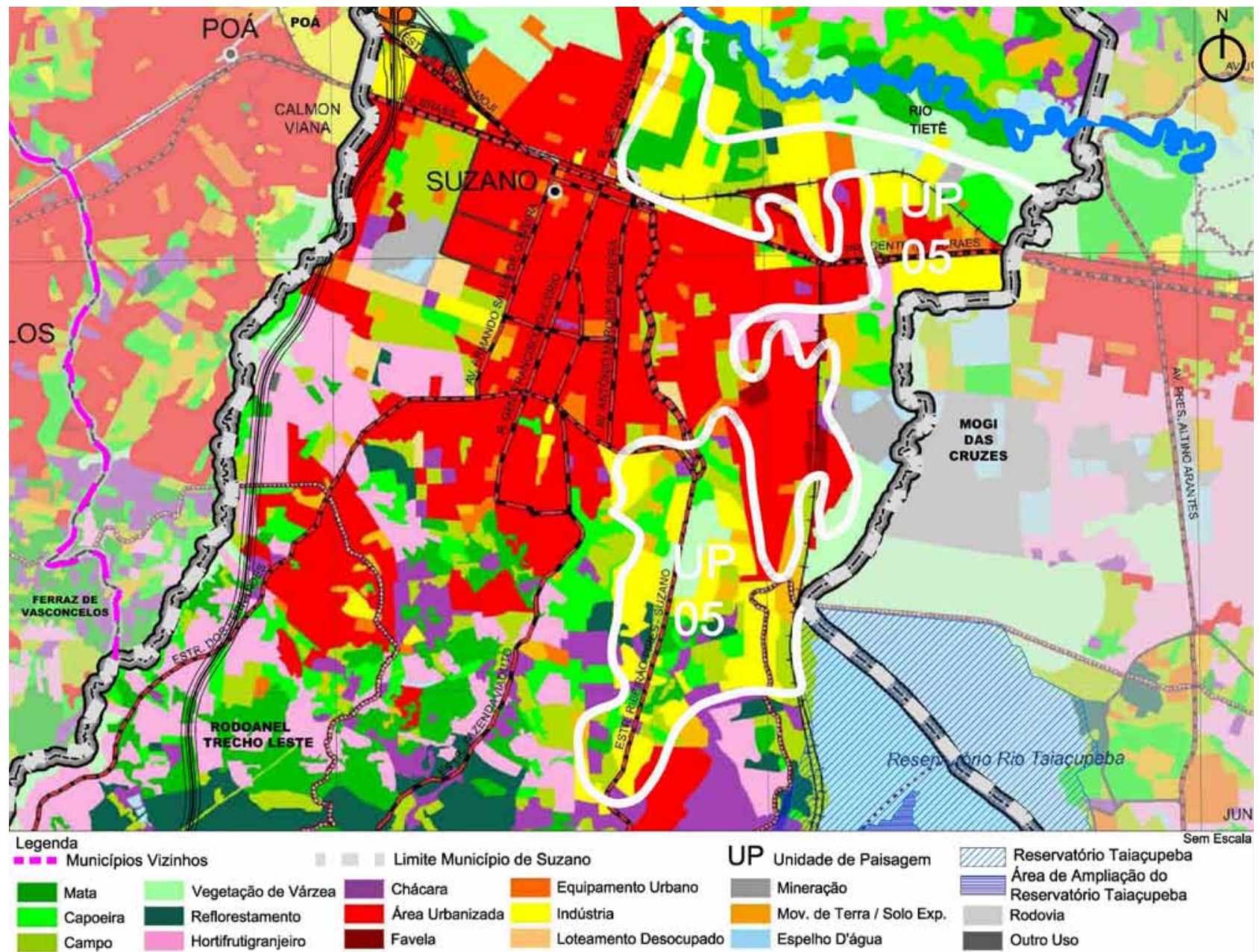

\section{Suzano - Unidade de Paisagem 05}

Fonte: Mapa criado por Michele de Sá Vieira e Sanderlei Fernandes Vilanova (2012), a partir do mapa do Uso e Ocupação do Solo da Empresa Paulista de Planejamento Metropolitano SA - EMPLASA, 2006 


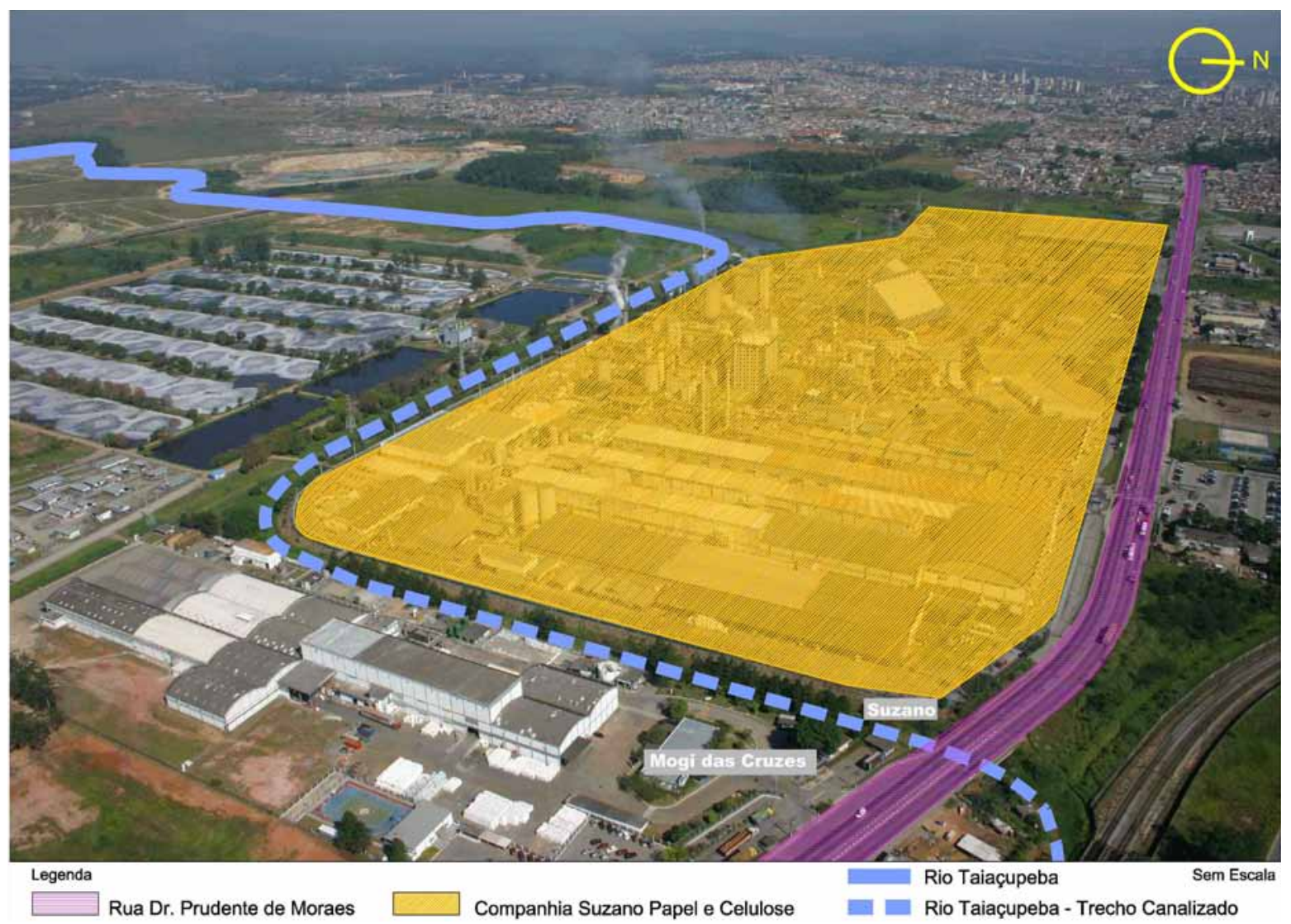

Suzano - Unidade de Paisagem 05. Com extenso parque industrial a Unidade Suzano situa-se próxima ao rio Taiaçupeba, ao longo da rua Doutor Prudente de Morais (SP 66), na divisa com o município de Mogi das Cruzes

Fonte: Prefeitura Municipal de Suzano, 2008 - imagem organizada por Michele de Sá Vieira e Sanderlei Fernandes Vilanova, 2012

\section{Conflitos}

A instalação intensa das indústrias junto à várzea do rio Tietê é sem dúvida o grande conflito existente nesta unidade de paisagem, pois parte das edificações estão dentro da própria Área de Proteção Ambiental (APA), enquanto outras se encontram próximas.

Os diversos pontos de movimentação de terra, com solo exposto, além da extensa cava de mineração, a qual inclusive se transpõe para o município de Mogi das Cruzes, gerando alta exploração com relação aos recursos minerais são outros pontos conflitantes. 


\section{Cenários futuros possíveis}

A existência de capoeiras, campos e vegetação de várzea, próximos à Represa de Taiaçupeba, além do valor cênico do local, contribuem de maneira significativa para que este espaço possa ter seu uso destinado ao turismo, recebendo estruturas vinculadas a atividades de recreação e lazer como os parques lineares nos locais próximos às ocupações e corredores ecológicos, nas áreas onde as ocupações não acontecem, mas que, no entanto, oferecem a possibilidade de serem potencializados pela vegetação. $\mathrm{Ou}$ seja, dado ao fato deste local possuir uma beleza luxuriante, ele se apresenta como um dos altos potenciais paisagísticos ambientais do território.

Como cenário futuro negativo entende-se que embora a várzea do Tietê seja uma das grandes potencialidades do município, o fato dela abrigar indústrias, bem como a ampliação e inserção de novos empreendimentos, entende-se que com esta consolidação a impermeabilização junto ao rio irá aumentar, podendo provocar desastres ambientais, que hoje (2012) já acontecem, como as inundações.

A expansão e consolidação das ocupações residenciais neste local também é um grave problema, pois provoca a ampliação da impermeabilização do solo, que contribui diretamente com o aumento das inundações, considerando-se que estes assentamentos estão situados na várzea do rio Tietê. 


\section{Unidade de Paisagem 06}

\section{Características}

Esta unidade de paisagem instalada sobre relevo praticamente plano se caracteriza principalmente pelo intenso cultivo de hortifrutigranjeiros, disseminados por toda a bacia do rio Guaió.

É também um espaço de grande interesse ambiental e eco-

\section{Suzano - Unidade de Paisagem 06} Fonte: Mapa criado por Michele de Sá Vieira e Sanderlei Fernandes Vilanova (2012), a partir de mapa aerofotogramétrico da Prefeitura Municipal de Suzano, 2008 lógico, em função de possuir diversos fragmentos de mata nativa, distribuídos sobre relevo um pouco mais acidentado em direção ao centro do território e, ainda, por ter áreas de campo e capoeira, além de uma pequena quantidade de vegetação de várzea junto ao Rio Guaió.

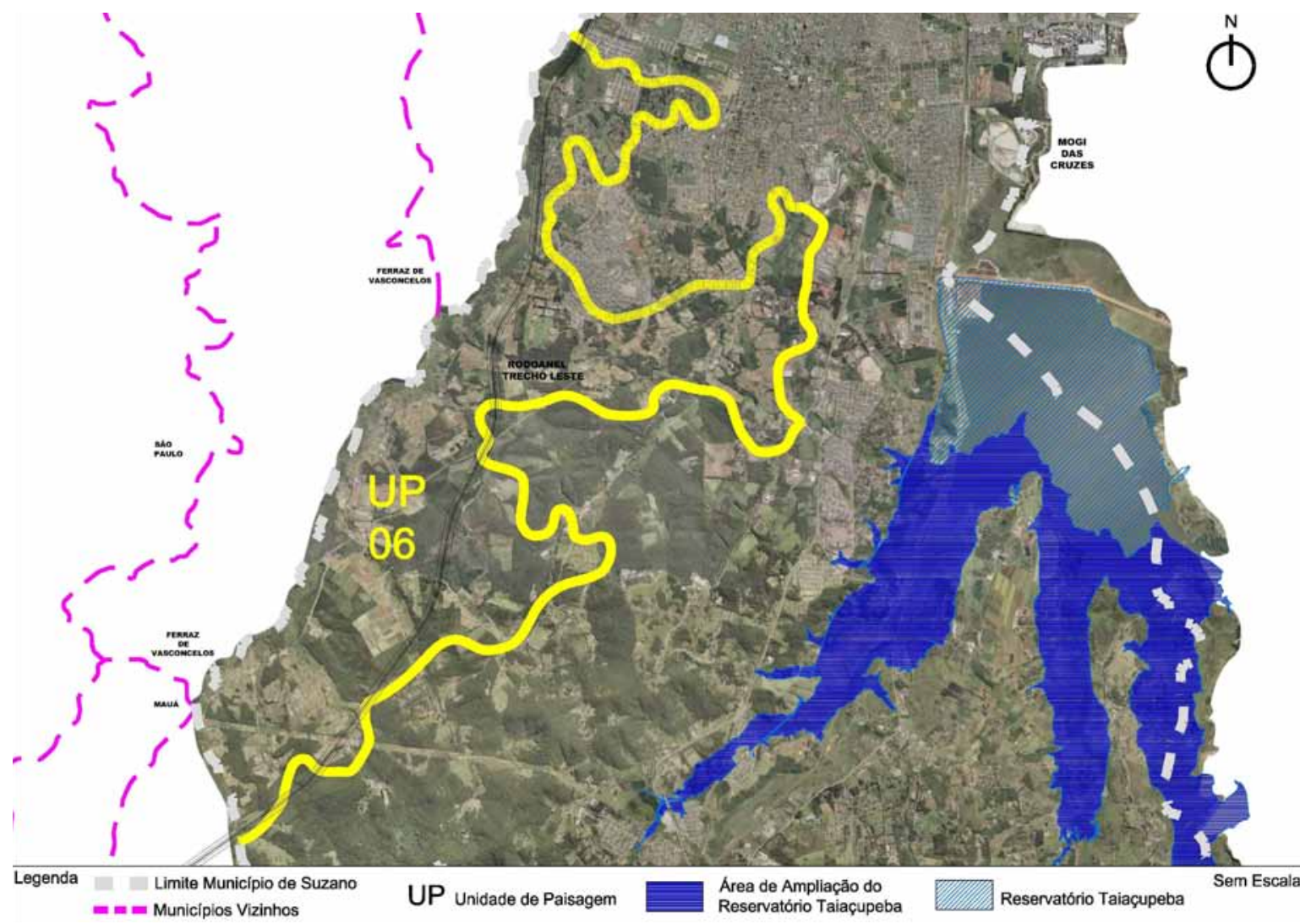


A existência de chácaras se dá de maneira menos expressiva quando comparamos com outras partes do território, como a Unidade de Paisagem 08.

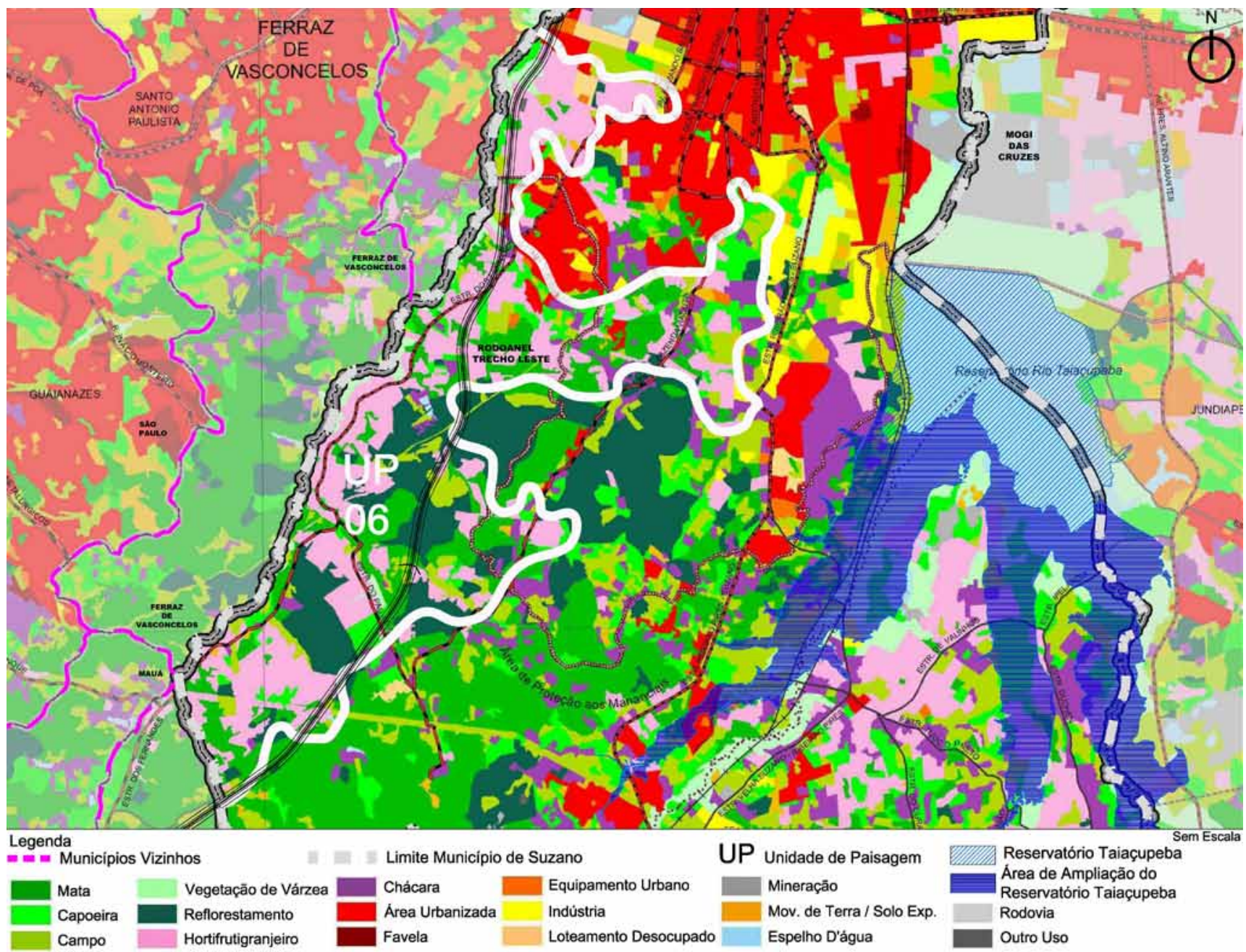

\section{Suzano - Unidade de Paisagem 06}

Fonte: Mapa criado por Michele de Sá Vieira e Sanderlei Fernandes Vilanova (2012), a partir do mapa do Uso e Ocupação do Solo da Empresa Paulista de Planejamento Metropolitano SA - EMPLASA, 2006 


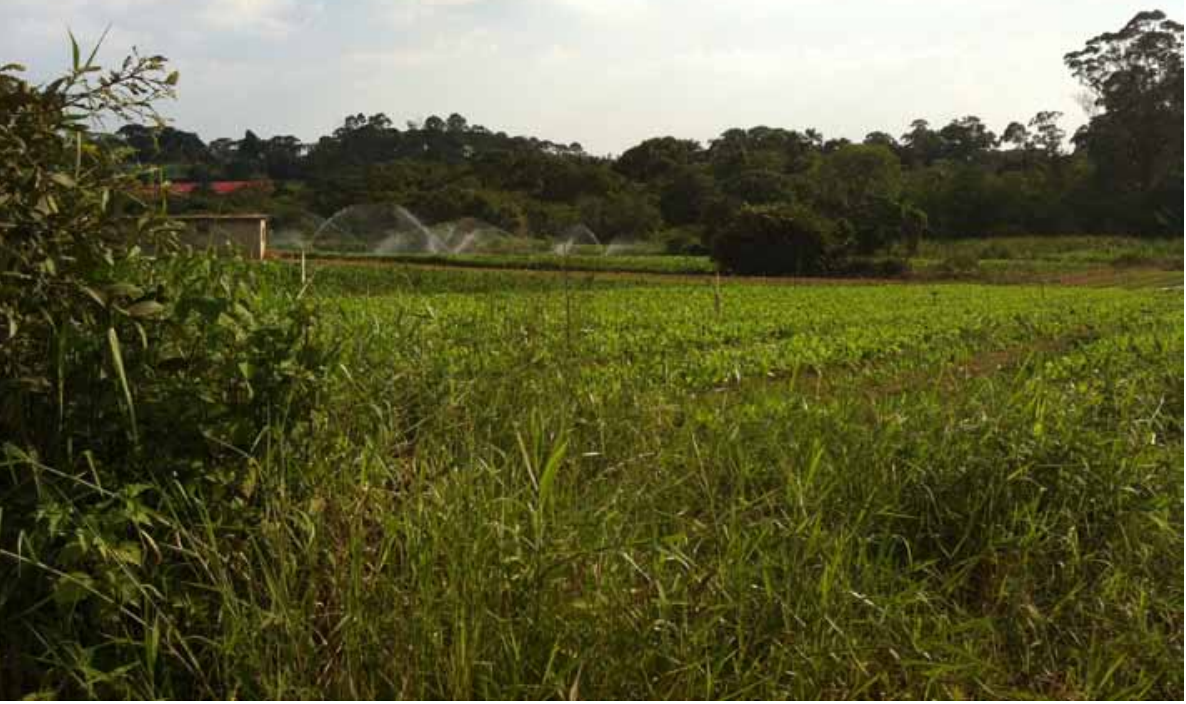

Suzano - Unidade de Paisagem 06. Ao longo da Estrada do Viaduto, esta unidade de paisagem contém uma das maiores áreas vinculadas ao cultivo da agricultura, sem dúvida a atividade é proveniente do rico sistema hídrico da bacia do Guaió

Fonte: Arquivo Michele de Sá Vieira, 2012

Suzano - Unidade de Paisagem 06. Embora o predomínio, no que se refere ao uso e ocupação do solo desta região, seja voltado para a agricultura e recobrimento de vegetação, aí se situam unidades habitacionais, por exemplo, na Estrada Santa Mônica

Fonte: Google maps, 2012

Suzano - Unidade de Paisagem 06. Embora parte da vegetação ao longo do Rio Guaió esteja preservada, com fragmentos de mata ciliar, observase que em alguns locais o solo está completamente exposto, como aparece neste trecho ao longo da Estrada Santa Mônica

Fonte: Google maps, 2012 


\section{Conflitos}

Existem situações que hoje (2012) contribuem intensamente para a degradação deste ambiente, como as movimentações de terra, que levam à exposição do solo, os desmatamentos pontuais, à caça ilegal de animais silvestres, além das grandes áreas de reflorestamento de eucalipto, que se impõem entre os fragmentos de mata nativa, promovendo rupturas na continuidade dos fluxos de energia destas manchas.

\section{Cenários futuros possiveis}

A criação de corredores ecológicos através do aproveitamento dos inúmeros fragmentos de mata, capoeiras e campos existentes, além da utilização do sistema hídrico expressivo na bacia do rio Guaió, trata-se de uma potencialidade positiva.

Gerado pelo Governo do Estado, a passagem do Rodoanel Leste irá propiciar a ruptura e extinção de diversos corpos d'água, fragmentos de vegetação, áreas voltadas à agricultura, bem como intensas movimentações de terra e retirada de famílias, além de não permitir a criação de corredores ecológicos que possibilitem a conexão de florestas de mata nativa existentes no município de Suzano. 


\section{Unidade de Paisagem 07}

\section{Características}

\section{Suzano - Unidade de Paisagem 07}

Fonte: Mapa criado por Michele de Sá Vieira e Sanderlei Fernandes Vilanova (2012), a partir de mapa aerofotogramétrico da Prefeitura Municipal de Suzano, 2008
Esta unidade possui relevo plano em alguns locais e um pouco mais acidentado em outros, contém o maior conjunto de chácaras do município próximo à Represa de Taiaçupeba, circundado por ocupações urbanas, vegetação de mata nativa, capoeiras, campos, cultivo de hortifrutigranjeiros e reflorestamento.

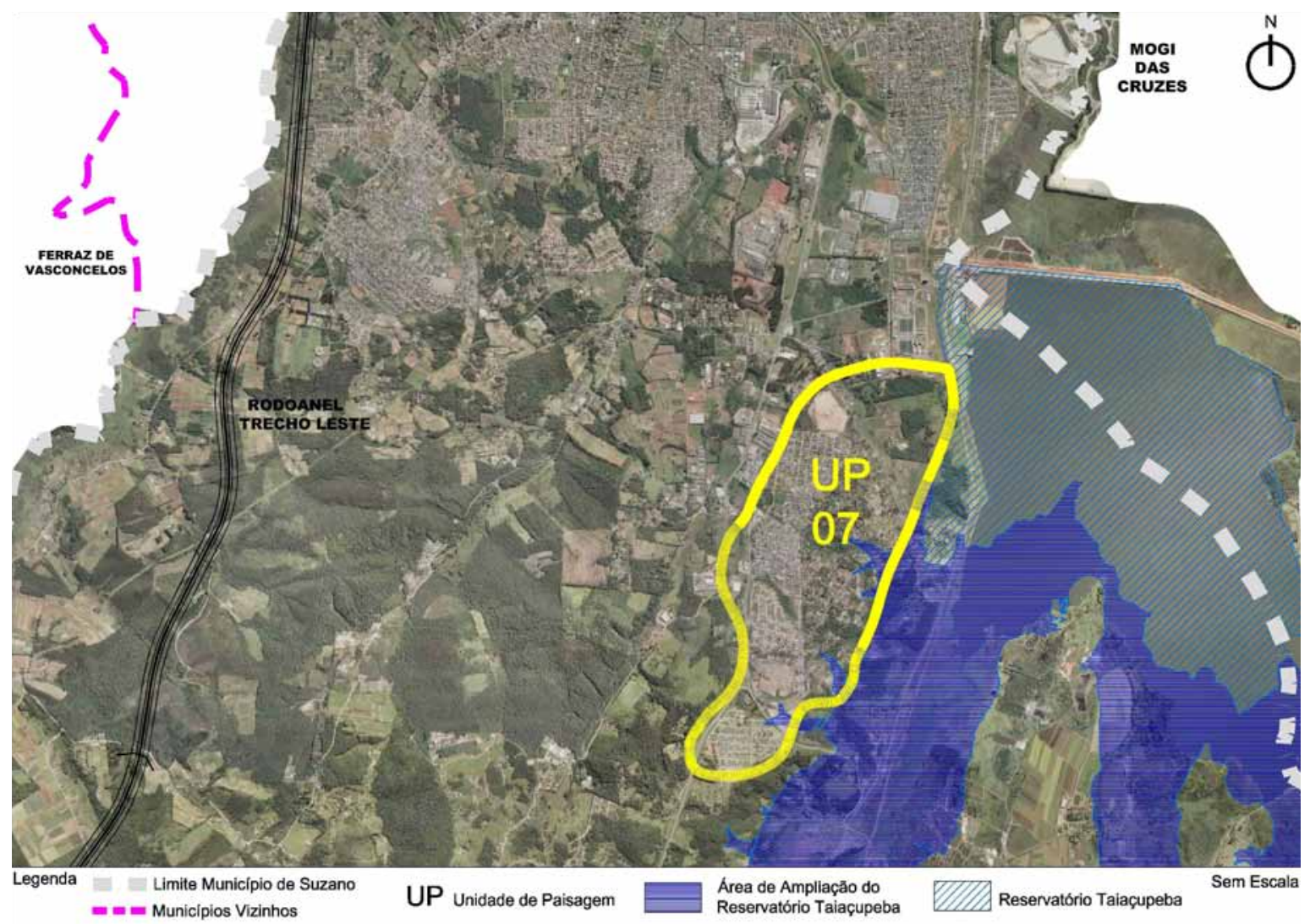




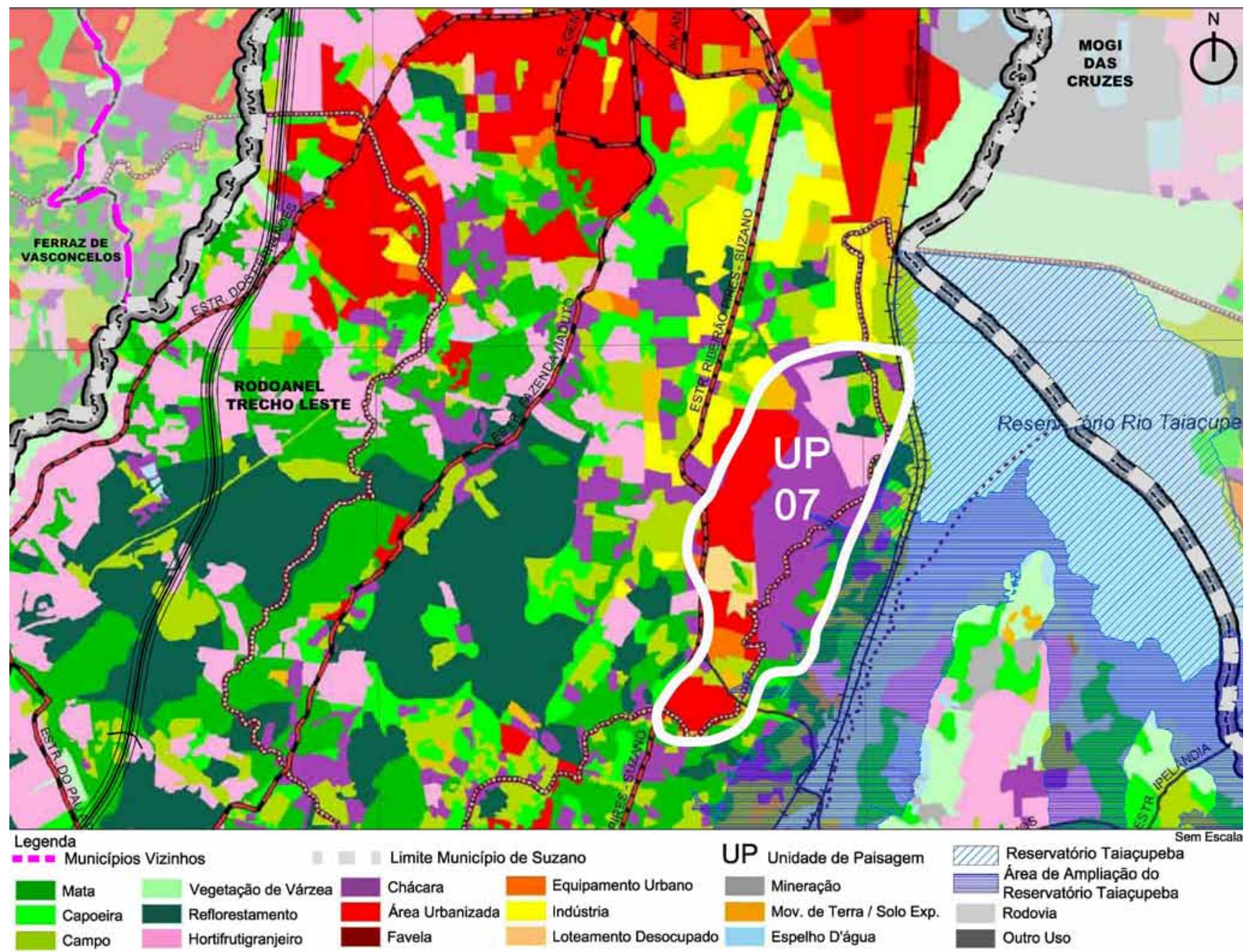

Suzano - Unidade de Paisagem 07

Fonte: Mapa criado por Michele de Sá Vieira e Sanderlei Fernandes Vilanova (2012), a partir do mapa do Uso e Ocupação do Solo da Empresa Paulista de Planejamento Metropolitano SA - EMPLASA, 2006 


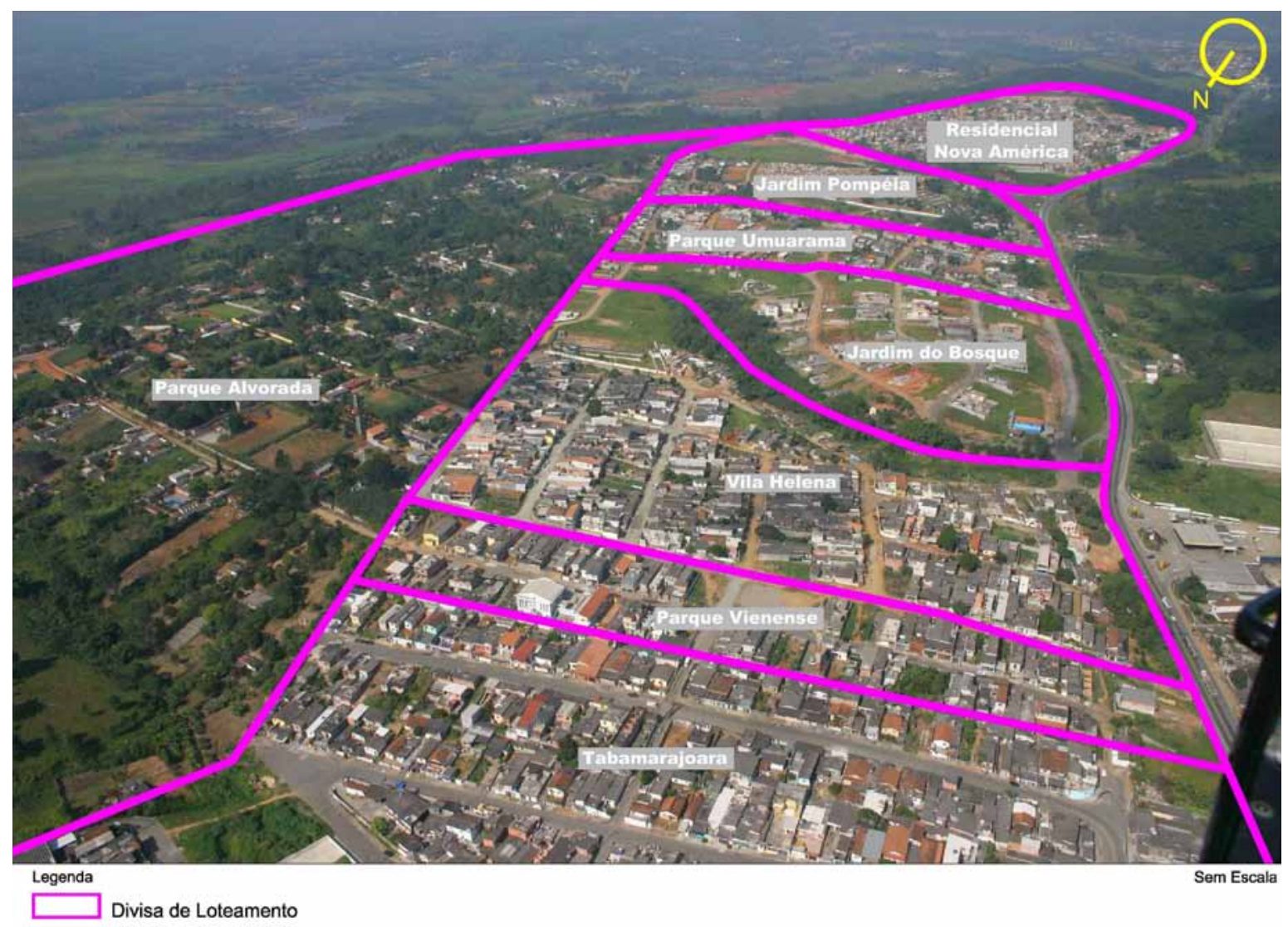

Suzano - Unidade de Paisagem

07. Os loteamentos Parque Vienense, Vila Helena, Jardim do Bosque, Parque Umuarama, Jardim Pompéia e Residencial Nova América, estão próximos à Represa de Taiaçupeba, podendo desfrutar de certa forma de futuras instalações turísticas que venham a ocorrer

Fonte: Prefeitura Municipal de Suzano, 2008 - imagem organizada por Michele de Sá Vieira e Sanderlei Fernandes Vilanova, 2012

\section{Conflitos}

A ampliação da represa irá propiciar a eliminação de espaços destinados ao cultivo de hortifrutigranjeiros, além de diversos recursos florestais, tais como: matas, campos e capoeiras, diminuindo dessa forma, os recursos ambientais existentes no território.

Outro conflito trata da movimentação de terra com solo exposto, a qual também acontece nesta unidade, devido especialmente às novas ocupações. 


\section{Cenários futuros possiveis}

Como cenário futuro positivo esta unidade contém uma das maiores oportunidades que o município oferece, pelo fato de poder abrigar estruturas turisticas, por estar próxima à Represa de Taiaçupeba, tendo a possibilidade, portanto, de explorar o seu valor cênico.

Como cenário negativo, a expansão constante das manchas de ocupação podem se sobrepor em relação à implementação de estruturas turísticas.

\section{Unidade de Paisagem 08 Características}

Possui a maior área em extensão do território, no que se refere aos interesses ecológicos, ambientais e paisagísticos, dado ao fato de possuir grandes fragmentos de matas nativas consolidados sobre relevo bastante colinoso e especial. Além disso, contém importantes áreas de reflorestamento, capoeiras e campos.

As chácaras recreativas ocupam parte significativa desta unidade, em contrapartida as áreas ocupadas pela indústria e cultivo de hortifrutigranjeiro são praticamente inexpressivas, em termos quantitativos. 


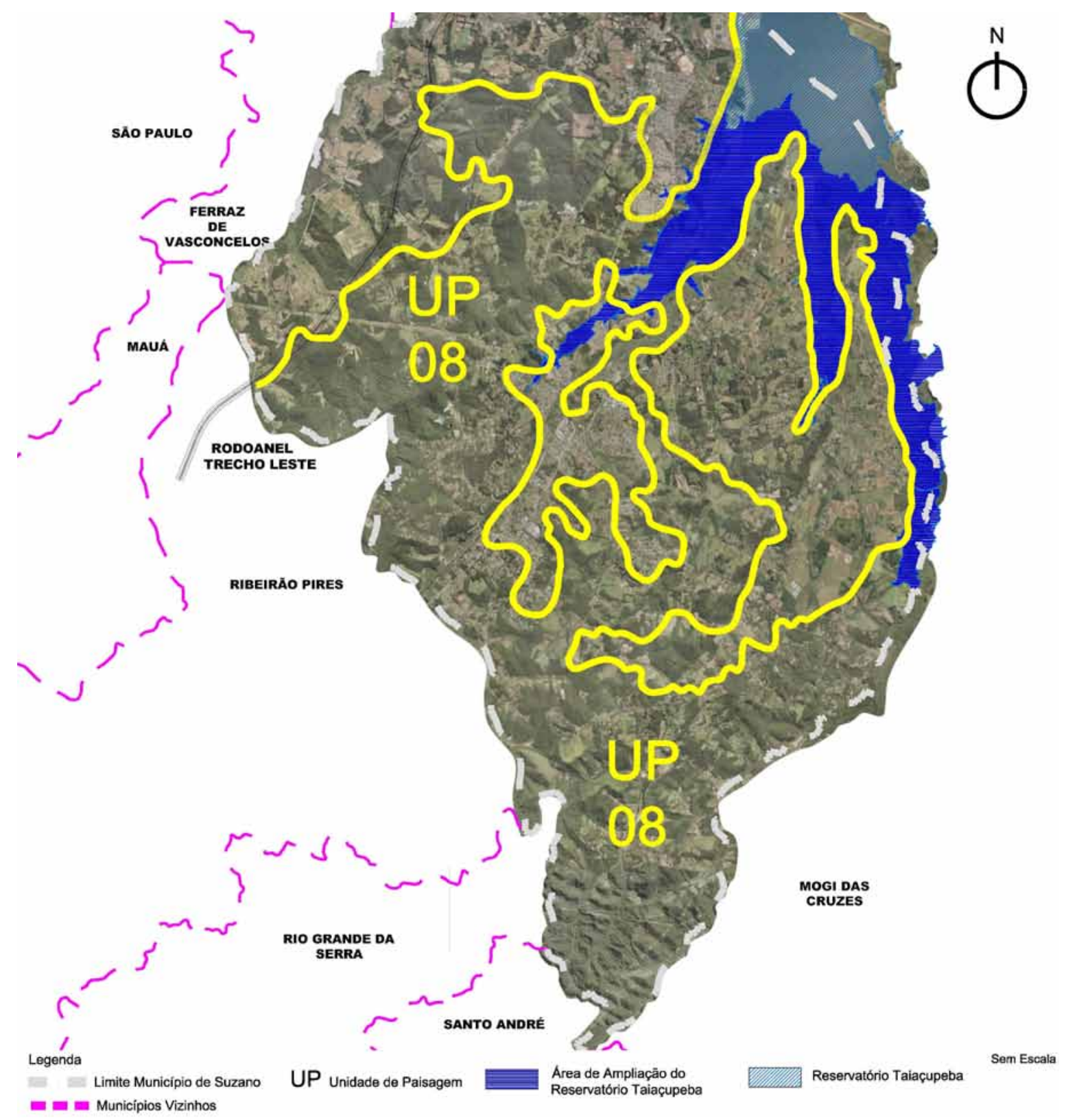

\section{Suzano - Unidade de Paisagem 08}

Fonte: Mapa criado por Michele de Sá Vieira e Sanderlei Fernandes Vilanova (2012), a partir de mapa aerofotogramétrico da Prefeitura Municipal de Suzano, 2008 


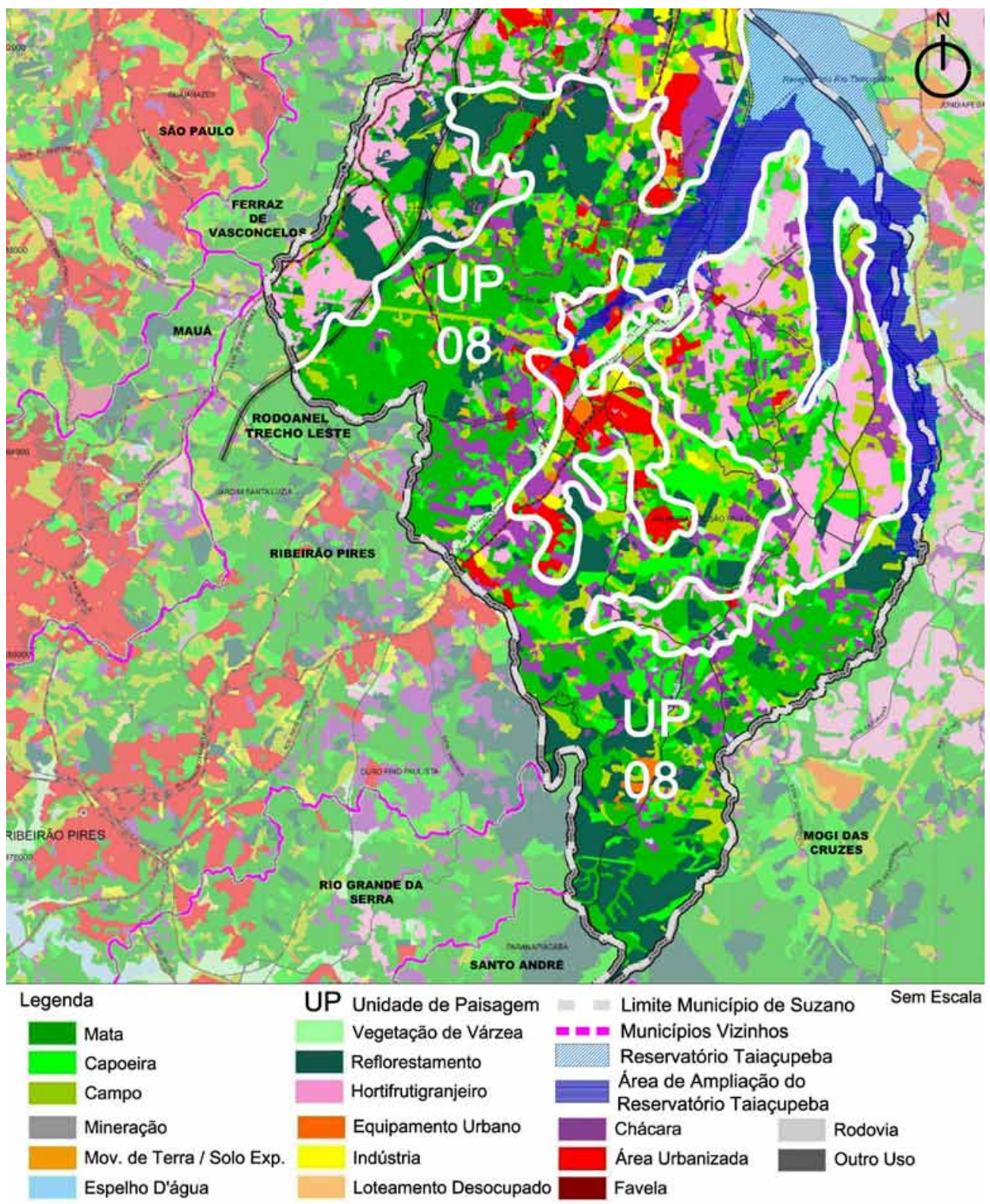

\section{Suzano - Unidade de Paisagem 08}

Fonte: Mapa criado por Michele de Sá Vieira e Sanderlei Fernandes Vilanova (2012), a partir do mapa do Uso e Ocupação do Solo da Empresa Paulista de Planejamento Metropolitano SA - EMPLASA, 2006 


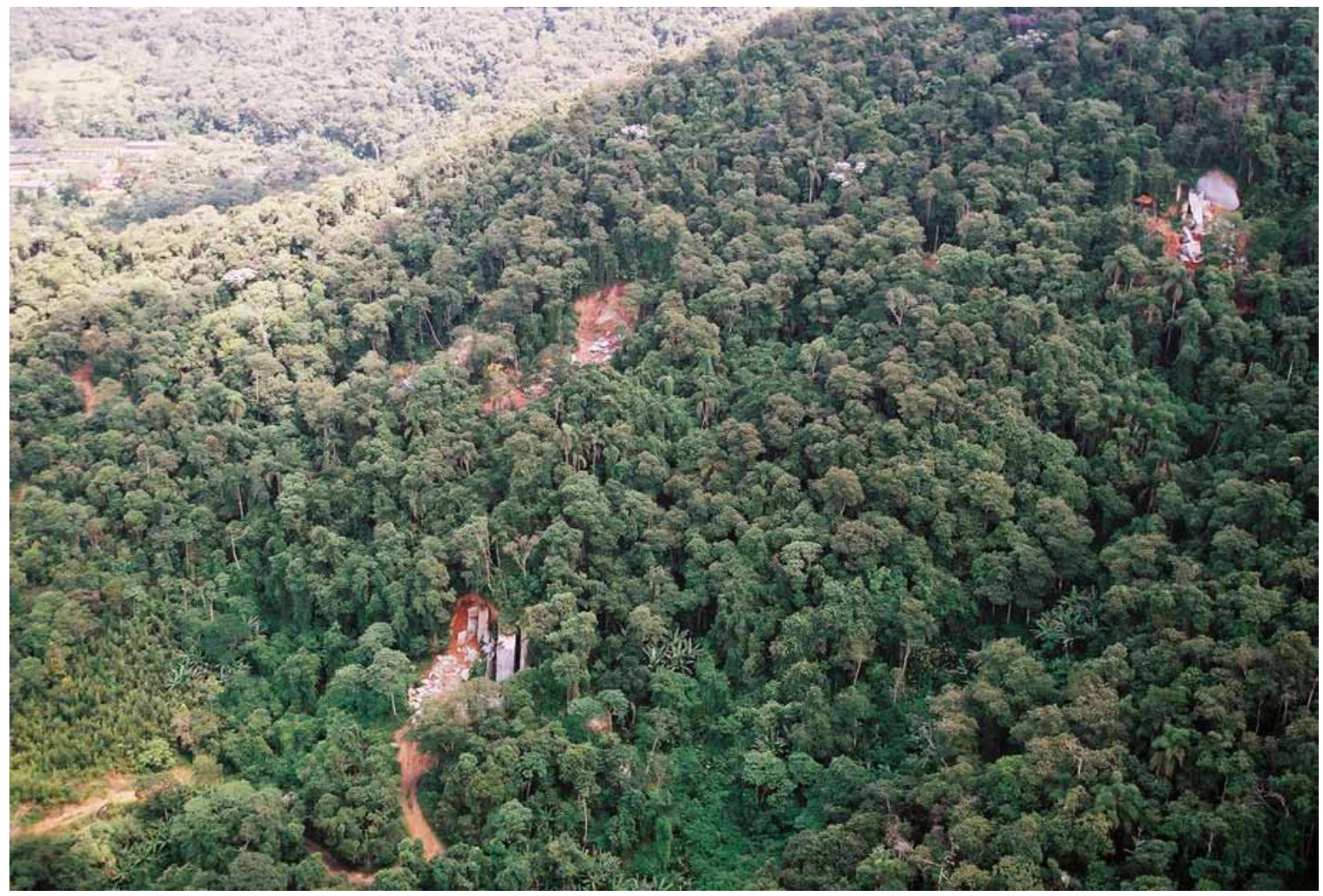

Suzano - Unidade de Paisagem

08. Se, por um lado, esta unidade apresenta características intensamente naturais, como a grande quantidade de fragmentos florestais e recursos hídricos, por outro, vê-se que a exploração mineral existente em alguns pontos dentro dos fragmentos de mata acaba por gerar a degradação das florestas, dado ao fato desta ser exercida, em diversos momentos, de forma predatória e irregular

Fonte: Prefeitura Municipal de Suzano, 2008.

\section{Conflitos}

As ocupações urbanas, as indústrias, a exploração mineral, a movimentação de terra com solo exposto, a disposição irregular de resíduos por municípios vizinhos, os desmatamentos pontuais, os reflorestamentos que se impõem entre os fragmentos de matas nativas, bem como a caça ilegal de animais silvestres, contribuem significativamente para com a degradação desta unidade de paisagem. 


\section{Cenários futuros possíveis}

Por esta unidade de paisagem ser a que contém a maior quantidade de fragmentos florestais naturais, ela, consequentemente, também possui as mais amplas possibilidades com relação ao estabelecimento de corredores ecológicos, para que estes possam ligar as manchas existentes.

Outros aspectos que podem ser observados para que estas conectividades aconteçam são os inúmeros espaços ocupados por capoeira e campos, que podem ser utilizados para a passagem dos corredores.

A existência do rico sistema hídrico é outra característica que contribui para que as manchas possam ser interligadas por fragmentos florestais lineares, uma vez que a água é um importante recurso, capaz de colaborar com esta ação

Atividades vinculadas ao alto valor cênico, como as turísticas-ecológicas, bem como a de extração vegetal e mineral regular, também podem ser desenvolvidas nesta região.

Como cenário negativo tem-se constantemente a eliminação total ou parcial de significativos corpos d'água e fragmentos florestais em função da expansão das ocupações urbanas, além das pressões advindas de fatores vinculados à agricultura e à exploração mineral.

Além disso, o interesse imobiliário, que tende a incentivar atividades vinculadas à exploração dos recursos naturais, como as paisagens que aí estão, também se torna um forte atrativo para que a região seja ocupada de maneira irregular por chácaras de recreio, entre outras. 


\section{Unidade de Paisagem 09}

\section{Características}

Embora esta região seja de grande interesse ecológico, am-

\section{Suzano - Unidade de Paisagem 09}

Fonte: Mapa criado por Michele de Sá Vieira e Sanderlei Fernandes Vilanova (2012), a partir de mapa aerofotogramétrico da Prefeitura Municipal de Suzano, 2008 biental e paisagístico, o que predomina são as ocupações urbanas dispostas em 7 blocos, todas situadas em relevo acidentado. 0 uso e a ocupação do solo deste espaço também são caracterizados pela presença de indústrias, chácaras, cultivo de hortifrutigranjeiro, fragmentos de mata nativa, campos e capoeiras.

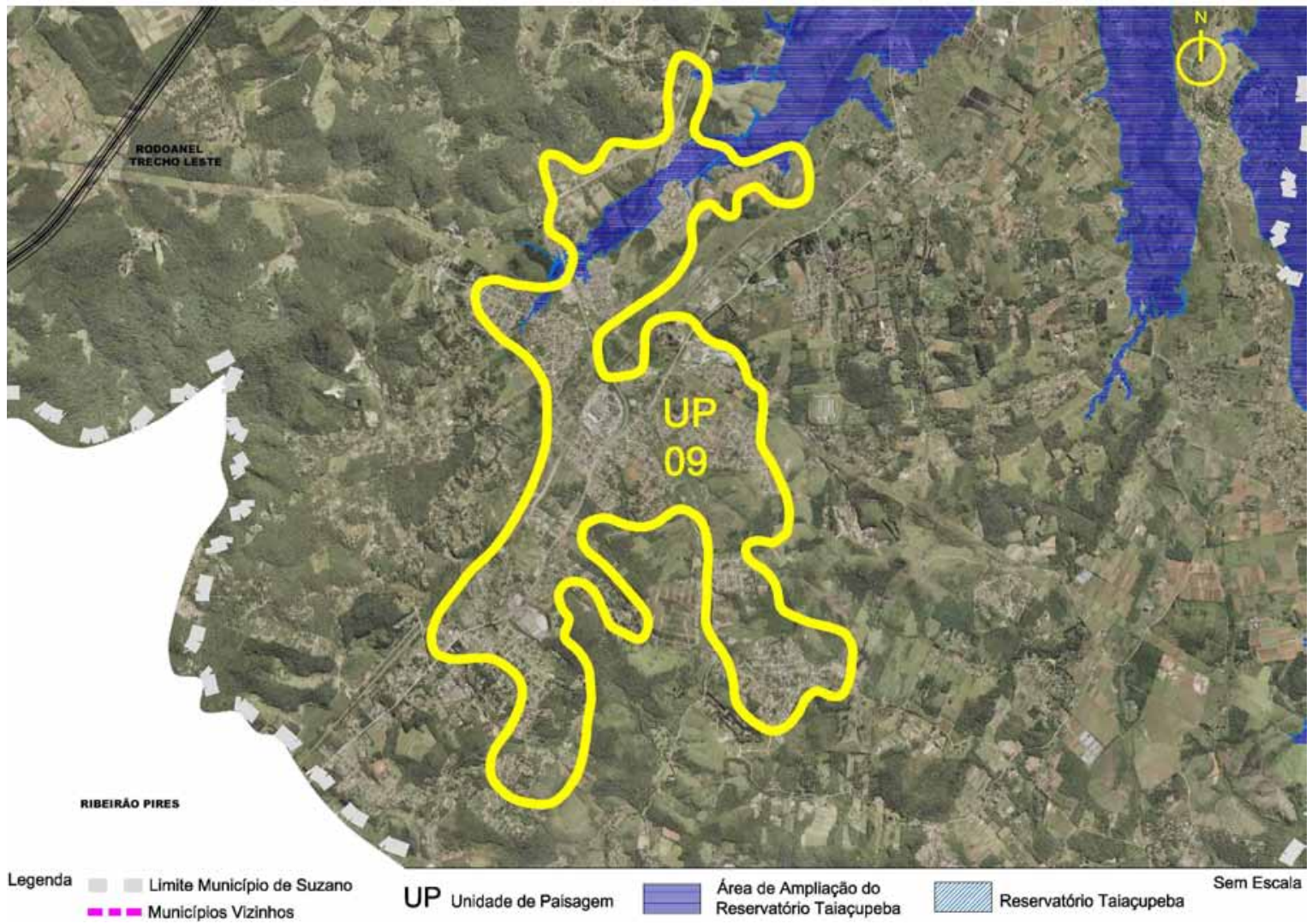




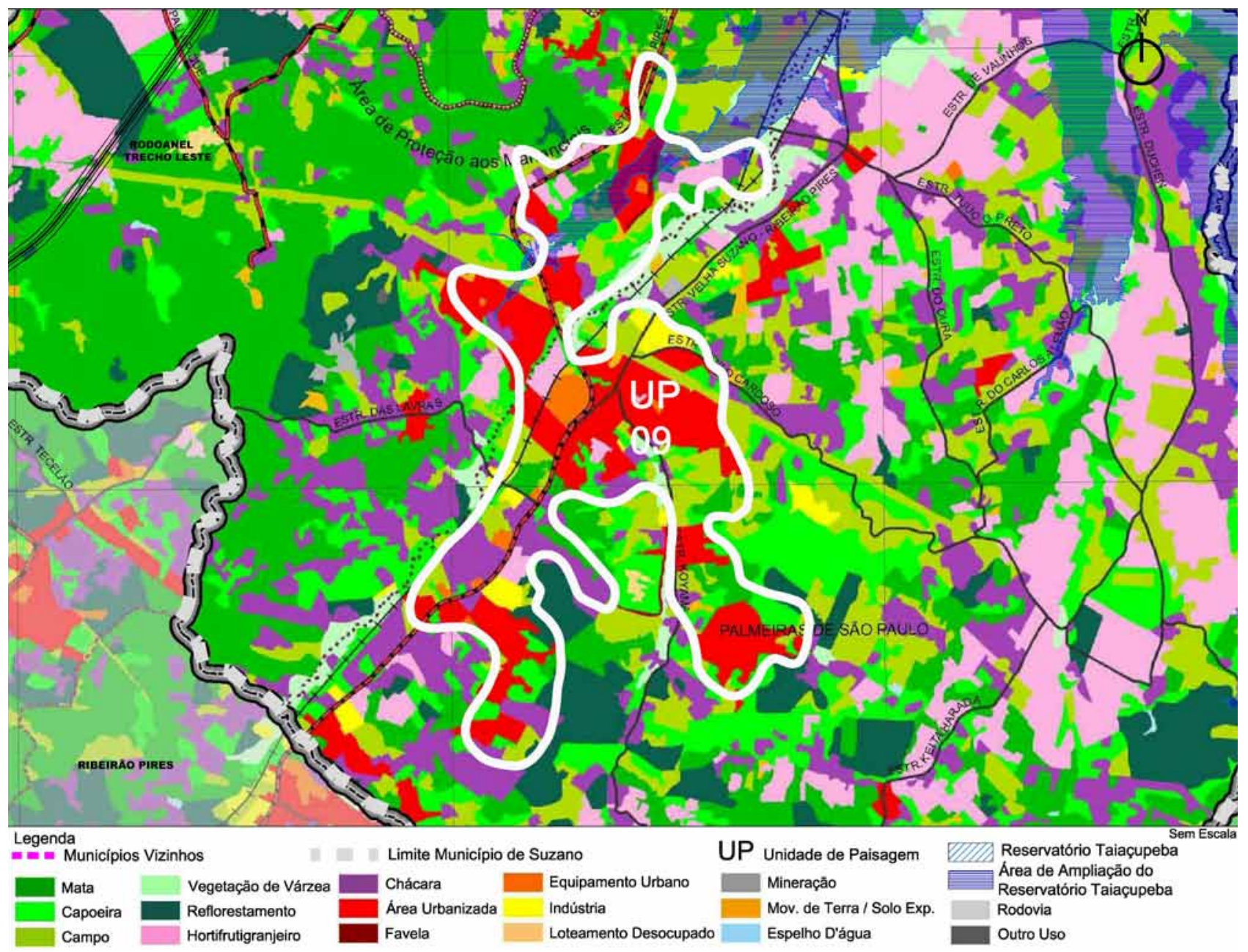

\section{Suzano - Unidade de Paisagem 09}

Fonte: Mapa criado por Michele de Sá Vieira e Sanderlei Fernandes Vilanova (2012), a partir do mapa do Uso e Ocupação do Solo da Empresa Paulista de Planejamento Metropolitano SA - EMPLASA, 2006. 


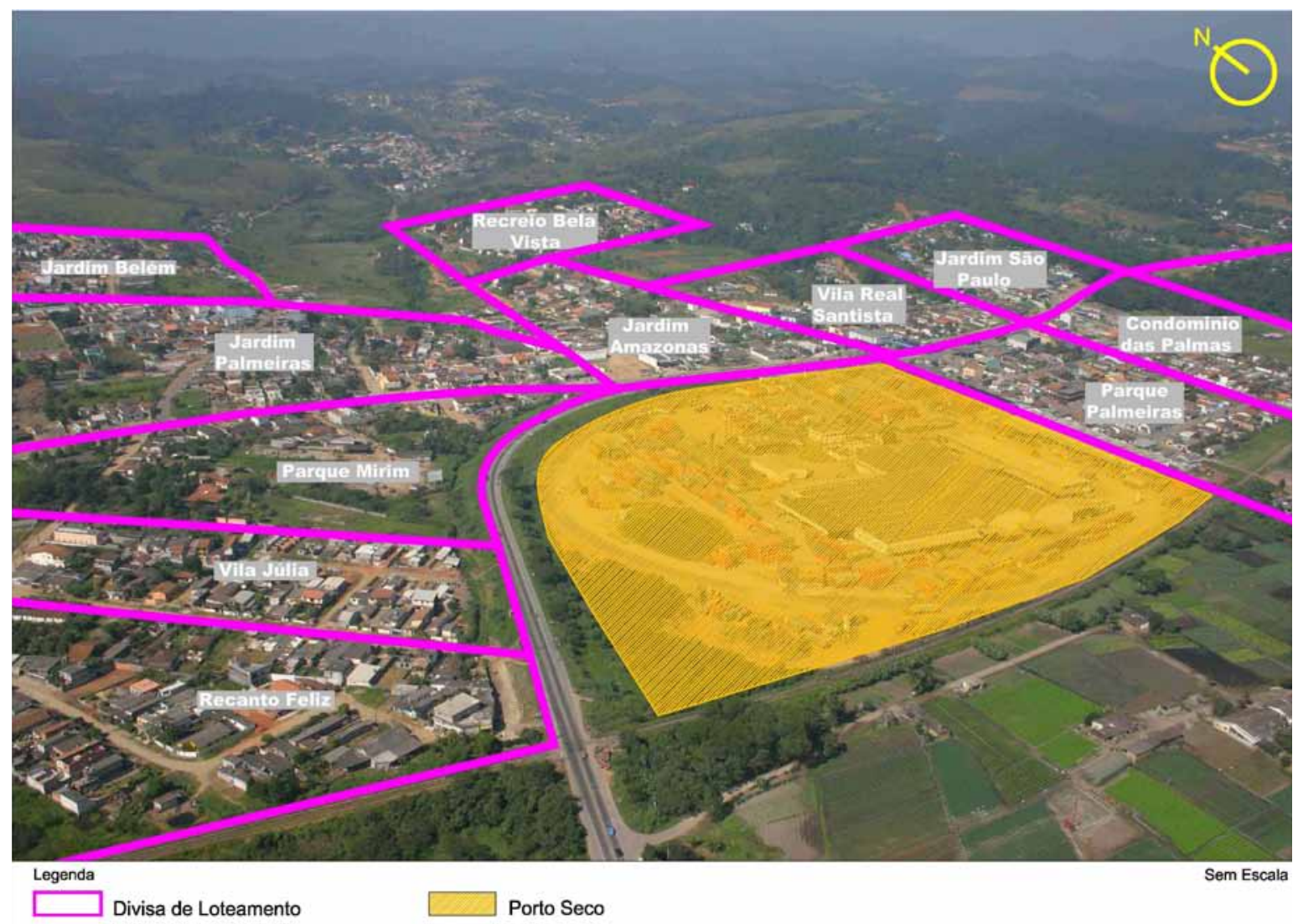

Suzano - Unidade de Paisagem 09. Ainda que entre as unidades de paisagem existentes, junto à Área de Proteção dos Mananciais, esta seja a que contenha a vegetação nativa mais degradada, em decorrência das ocupações urbanas por loteamentos como o Jardim Amazonas, Vila Real Santista, Parque Palmeiras, Recanto Feliz, Condomínio das Palmas, entre outros, esta também possui valor cênico, dado ao fato do seu entorno imediato ser cercado por fragmentos florestais Fonte: Prefeitura Municipal de Suzano, 2008 - imagem organizada por Michele de Sá Vieira e Sanderlei Fernandes Vilanova, 2012 


\section{Conflitos}

As ocupações urbanas existentes nesta unidade são o elemento principal gerador de conflitos na Área de Proteção dos Mananciais (APM), em função da degradação ambiental promovidas por elas. Além disso, também se constituem como uma barreira para que ocorra uma possivel conexão entre os fragmentos de mata nativa existentes na Unidade de Paisagem 08.

No que se refere à vegetação, os desmatamentos pontuais, assim como a caça de animais silvestres e a presença de indústrias neste espaço que possui tantos fragmentos, ampliam a degradação da região.

\section{Cenários futuros possíveis}

Por outro lado, a existência de fragmentos de mata nativa, capoeira e campo, permitem o desenvolvimento de interligações com as demais manchas de mata nativa existentes no entorno.

Os fragmentos de mata, capoeira e campo, bem como a presença das ocupações, indicam a possibilidade da implantação de parques lineares junto à ampliação da Represa de Taiaçupeba, possibilitando assim que a população local tenha áreas de recreação aquática.

Apesar da enorme potencialidade paisagística existente na região sul do território, o que se verifica é que os fortes núcleos de ocupações urbanas presentes, a exemplo dos que existem na Unidade de Paisagem 09, tendem a se expandir e consolidar, gerando como consequência a extinção e contaminação de significativos fragmentos florestais e corpos d'água. 


\section{Unidade de Paisagem 10}

\section{Características}

Assentada sobre relevo parcialmente plano e colinoso, a unidade possui como principal característica um forte caráter paisagístico, por ser lindeira à Represa de Taiaçupeba. Na área existem extensas regiões de chácaras vinculadas ao cultivo de hortifruti-

\section{Suzano - Unidade de Paisagem 10}

Fonte: Mapa criado por Michele de Sá Vieira e Sanderlei Fernandes Vilanova (2012), a partir de mapa aerofotogramétrico da Prefeitura Municipal de Suzano, 2008 granjeiro.

No que se refere à vegetação, suas diversas áreas de campo, capoeiras, fragmentos de mata nativa e vegetação de várzea, dão a esta unidade um grande caráter ecológico e ambiental.

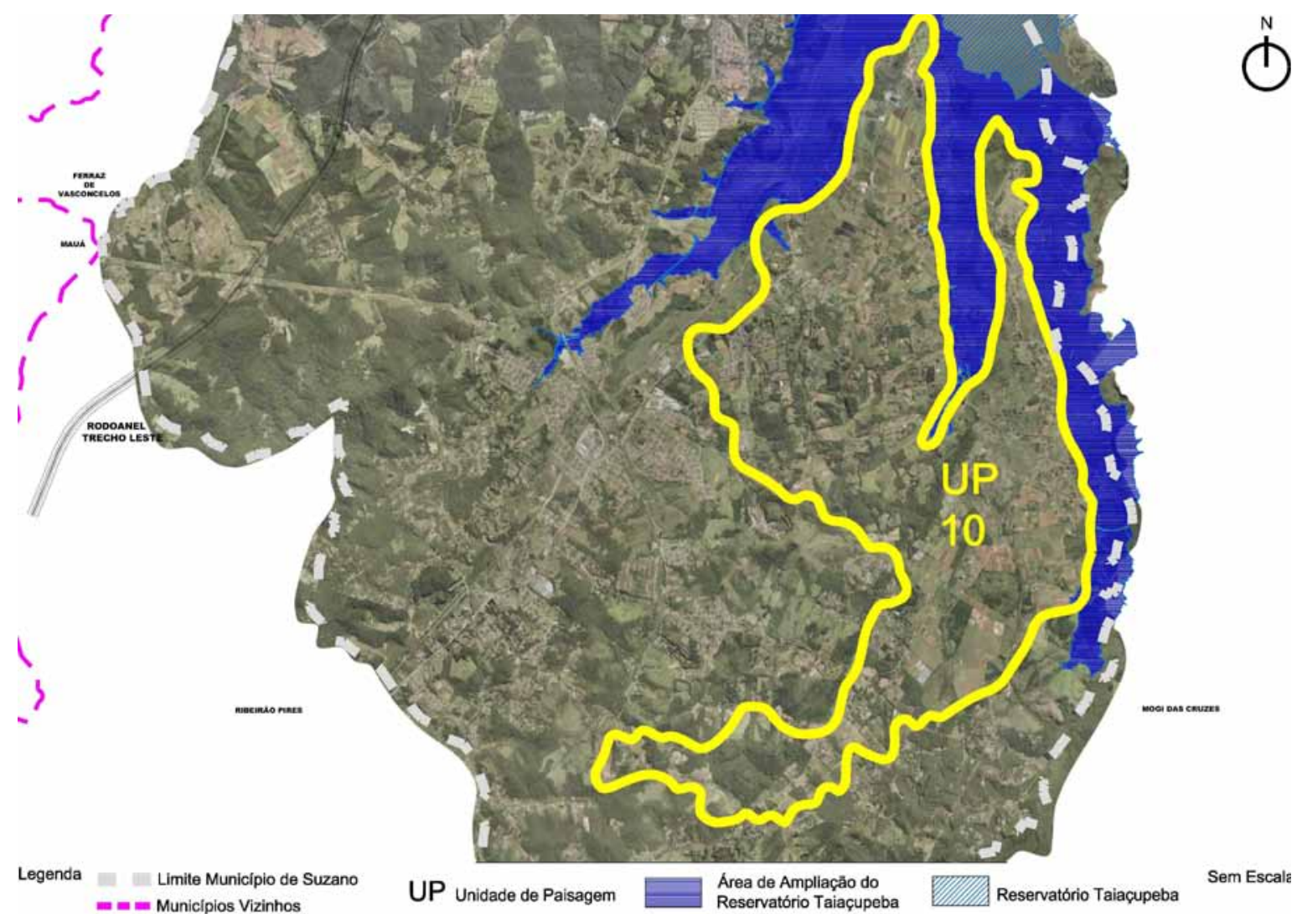




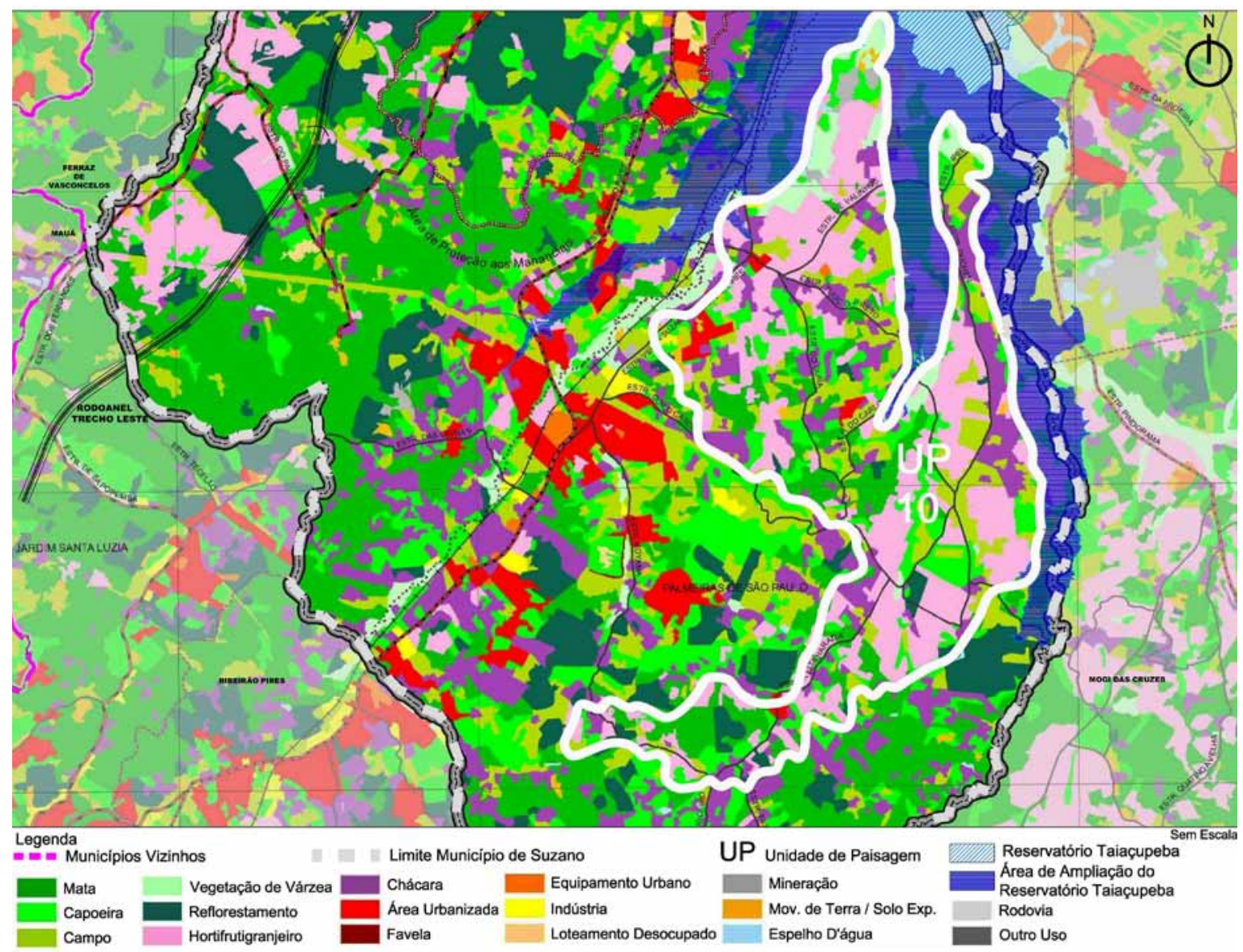

\section{Suzano - Unidade de Paisagem 10}

Fonte: Mapa criado por Michele de Sá Vieira e Sanderlei Fernandes Vilanova (2012), a partir do mapa do Uso e Ocupação do Solo da Empresa Paulista de Planejamento Metropolitano SA - EMPLASA, 2006 


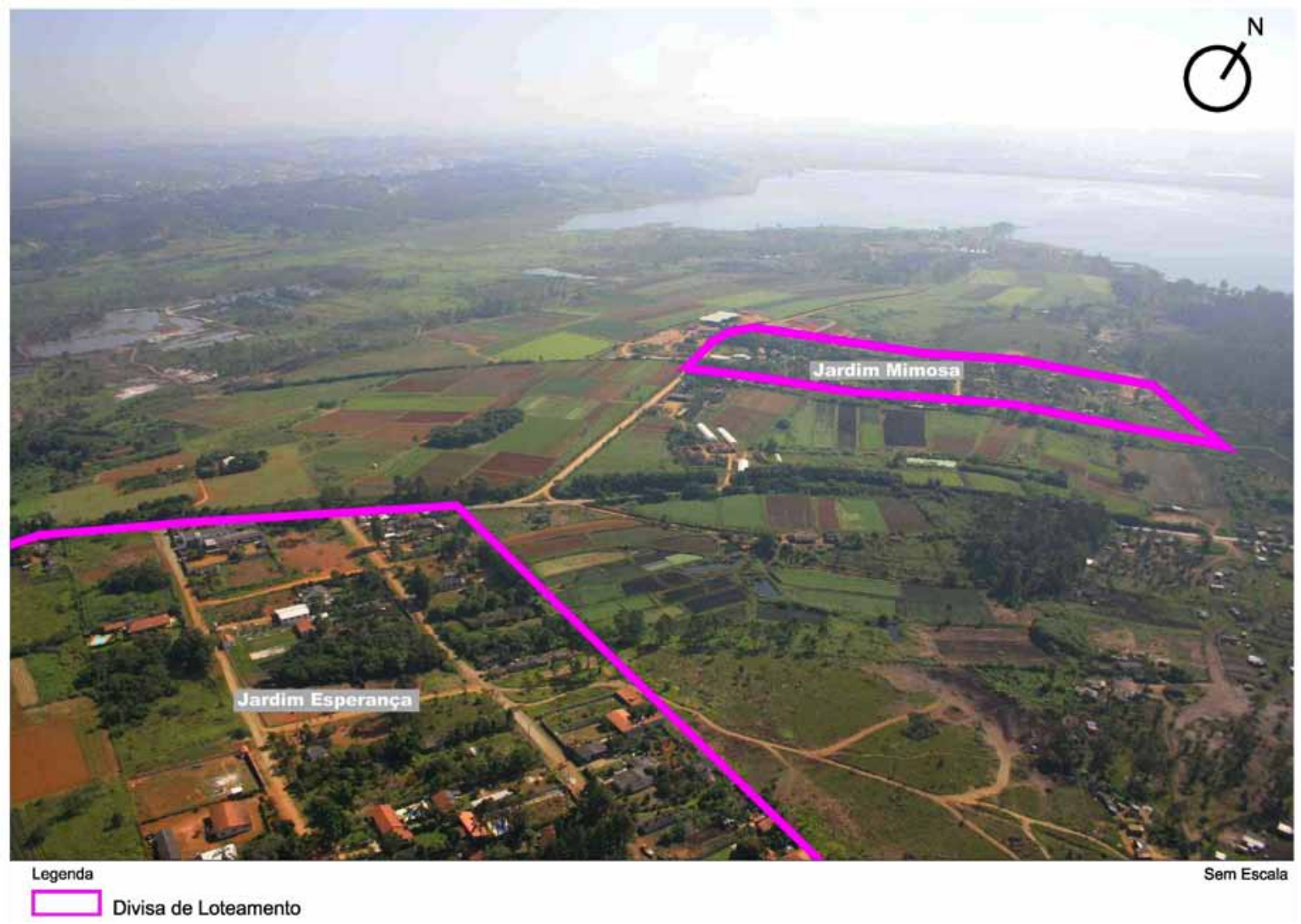

Suzano - Unidade de Paisagem 10. Em decorrência da proximidade da urbanização, com relação a Represa de Taiaçupeba, parques lineares podem ser implantados, considerando-se que a população que vive em loteamentos como Jardim Esperança e Jardim Mimosa, por estarem próximos poderão fazer uso dos equipamentos.

Fonte: Prefeitura Municipal de Suzano, 2008 imagem organizada por Michele de Sá Vieira e Sanderlei Fernandes Vilanova, 2012

Suzano - Unidade de Paisagem 10. Em locais onde a população não se faz presente, uma das opções para se promover a recuperação das áreas degradadas é através da implementação de corredores ecológicos ao longo da Represa de Taiaçupeba

Fonte: Prefeitura Municipal de Suzano, 2008

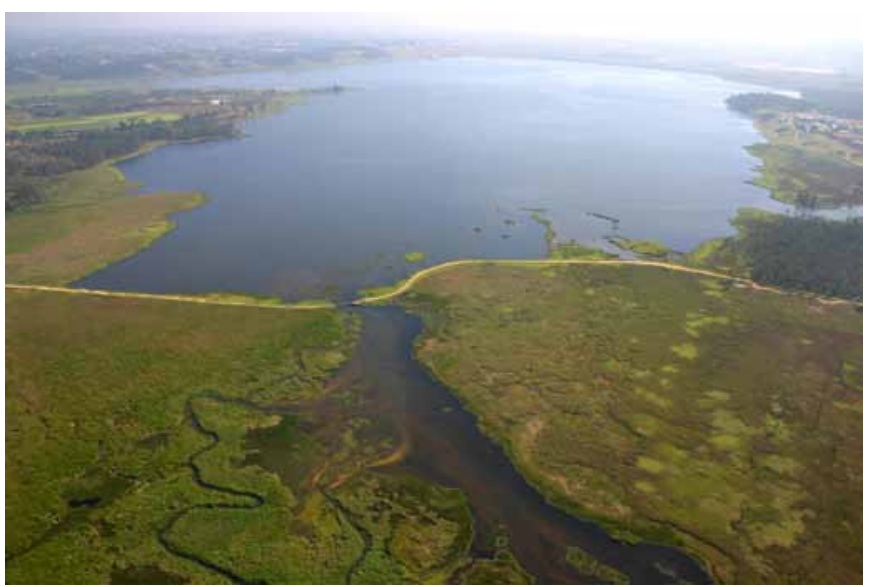




\section{Conflitos}

Com relação aos conflitos, eles ocorrem em função da presença das ocupações urbanas desprovidas de infraestrutura vinculada ao saneamento, bem como da forma intensa que a agricultura usufrui dos recursos hídricos.

No que se refere à vegetação, registram-se alguns fatos que contribuem para a sua extinção nesta unidade de paisagem como:

- a expansão da Represa de Taiaçupeba, que propiciará a supressão de diversos tipos de vegetação;

- a intensa presença da agricultura, a qual funciona como uma barreira entre os fragmentos de mata existente, deixando-os isolados;

- os desmatamentos pontuais, assim como a caça ilegal de animais silvestres, que também contribuem para a extinção dos fragmentos nesta região.

\section{Cenários futuros possíveis}

As atividades futuras nesta unidade estão vinculadas ao turismo e, portanto, à valorização da paisagem, dado ao fato de possuir alto valor cênico, por estar próxima à Represa de Taiaçupeba, os espaços junto a ela permitem a incorporação de atividades voltadas ao lazer e à recreação como a pesca.

Outro aspecto a ser desenvolvido relaciona-se a valores voltados à recuperação ecossistêmica, pois como esta unidade contém vegetação de várzea, fragmentos de mata nativa, áreas de campo e capoeiras, corredores podem ser propostos a fim de promover conexões que restabeleçam os ecossistemas antes existentes. 
Por outro lado, tem-se a tendência com relação à extinção e contaminação de significativos corpos d'água e fragmentos florestais em função da expansão e consolidação das ocupações urbanas irregulares pontuais, que tendem a se ampliar, além da intensa atividade vinculada à agricultura, bem como pela existência de inúmeras chácaras.

\section{Síntese das unidades de paisagens}

Após a análise das 10 unidades de paisagem, segue o quadro-sintese, onde se aponta o resumo das características físicas, dos conflitos, dos cenários futuros possíveis, bem como a relação de alguns dos inúmeros projetos, planos e ações públicas executados entre os anos de 2005 e 2011. 


\begin{tabular}{|c|c|c|c|c|c|}
\hline $\begin{array}{l}\text { Unidades de } \\
\text { paisagens }\end{array}$ & $\begin{array}{l}\text { Características } \\
\text { físicas }\end{array}$ & Conflitos & $\begin{array}{l}\text { Cenários futuros pos- } \\
\text { síveis }\end{array}$ & $\begin{array}{l}\text { Cenários futuros } \\
\text { possíveis }\end{array}$ & $\begin{array}{l}\text { Principais projetos, planos e } \\
\text { ações públicas já executadas }\end{array}$ \\
\hline UP 01 & $\begin{array}{l}\text { - relevo plano e } \\
\text { inclinado; } \\
\text { - loteamentos alta- } \\
\text { mente ocupados; } \\
\text { - indústrias; } \\
\text { - plantações de ho- } \\
\text { tifrutigranjeiros; } \\
\text { - chácaras; } \\
\text { - fragmentos de } \\
\text { mata nativa; } \\
\text { - capoeiras e cam- } \\
\text { pos. }\end{array}$ & $\begin{array}{l}\text { - intenso adensa- } \\
\text { mento populacio- } \\
\text { nal; } \\
\text { - ocupações com } \\
\text { baixa qualidade } \\
\text { estética; } \\
\text { - poluição sanitária; } \\
\text { - ocupações irregu- } \\
\text { lares em área de } \\
\text { várzea; } \\
\text { - escassez de espaços } \\
\text { livres tratados; } \\
\text { - ausência de convi- } \\
\text { vência da popula- } \\
\text { ção com a várzea do } \\
\text { Tietê; } \\
\text { - movimentação } \\
\text { de terra com solo } \\
\text { exposto; } \\
\text { - queimadas no } \\
\text { parque Mirante do } \\
\text { Tietê. }\end{array}$ & $\begin{array}{l}\text { - convivência da po- } \\
\text { pulação com o futuro } \\
\text { Parque Várzeas do } \\
\text { Tietê; } \\
\text { - canteiros centrais capa- } \\
\text { zes de abrigar arboriza- } \\
\text { ção urbana e ciclovias; } \\
\text { - sistema hídrico, capaz } \\
\text { de abrigar parques } \\
\text { lineares; } \\
\text { - praças que podem } \\
\text { ser tratadas visando } \\
\text { atender as demandas } \\
\text { da população; } \\
\text { - Parque Mirante do } \\
\text { Tietê, contém gran- } \\
\text { de potencial para se } \\
\text { transformar em local } \\
\text { de lazer, recreação e } \\
\text { recuperação ambiental; } \\
\text { - universalização dos } \\
\text { serviços de água e } \\
\text { esgoto pela SABESP até } \\
\text { 2018. }\end{array}$ & $\begin{array}{l}\text { - o acumulo de resí- } \\
\text { duos da construção } \\
\text { civil tende a se } \\
\text { ampliar no Parque } \\
\text { Mirante do Tietê; } \\
\text { - expansão e } \\
\text { consolidação das } \\
\text { ocupações residen- } \\
\text { ciais irregulares. }\end{array}$ & $\begin{array}{l}\text { - obras de infraestrutura urbana: } \\
\text { pavimentação, redes de abas- } \\
\text { tecimento de água e coleta de } \\
\text { esgoto, além de atendimento de } \\
\text { iluminação pública; } \\
\text { - implantação do Parque Linear } \\
\text { Ecológico Jaguari; } \\
\text { - implantação do Corredor Ecoló- } \\
\text { gico Recreativo no loteamento } \\
\text { Jardim Revista; } \\
\text { - construção de equipamentos } \\
\text { públicos, tais como: creches, es- } \\
\text { colas, centro cultural, unidades } \\
\text { básicas de saúde, entre outros; } \\
\text { - projetos de urbanização de áre- } \\
\text { as degradadas nos loteamentos } \\
\text { Cidade Miguel Badra, Jaguari e } \\
\text { Planalto; } \\
\text { • projetos de ciclovias para as } \\
\text { avenidas Miguel Badra e Edmil- } \\
\text { son Rodrigues Marcelino; } \\
\text { - desenvolvimento do Plano } \\
\text { Municipal de Saneamento } \\
\text { Ambiental. }\end{array}$ \\
\hline
\end{tabular}

\begin{tabular}{|c|c|c|c|c|c|}
\hline $\begin{array}{l}\text { Unidades de } \\
\text { paisagens }\end{array}$ & $\begin{array}{l}\text { Características } \\
\text { físicas }\end{array}$ & Conflitos & $\begin{array}{l}\text { Cenários futuros } \\
\text { possíveis }\end{array}$ & $\begin{array}{l}\text { Cenários futuros } \\
\text { possíveis }\end{array}$ & $\begin{array}{l}\text { Principais projetos, planos e } \\
\text { ações públicas já executadas }\end{array}$ \\
\hline UP 02 & $\begin{array}{l}\text { - relevo em geral } \\
\text { acidentado e } \\
\text { em alguns locais } \\
\text { plano; } \\
\text { - reflorestamentos, } \\
\text { campos, capoeiras } \\
\text { e matas; } \\
\text { - plantações de } \\
\text { hortifrutigran- } \\
\text { jeiros; } \\
\text { - áreas de cháca- } \\
\text { ras. }\end{array}$ & $\begin{array}{l}\text { - movimentação } \\
\text { de terra com solo } \\
\text { exposto; } \\
\text { - exploração do } \\
\text { sistema hídrico em } \\
\text { função da agricul- } \\
\text { tura; } \\
\text { - baixa qualidade com } \\
\text { relação aos aspectos } \\
\text { urbanísticos. }\end{array}$ & $\begin{array}{l}\text { • estabelecer conexões } \\
\text { através de corredores } \\
\text { ecológicos com os } \\
\text { fragmentos de mata } \\
\text { nativa da serra do } \\
\text { Itapety; } \\
\text { - estabelecer cone- } \\
\text { xões, através de } \\
\text { corredores ecológicos } \\
\text { com os fragmentos } \\
\text { de mata nativa exis- } \\
\text { tentes na várzea do } \\
\text { rio Tietê; } \\
\text { - universalização dos } \\
\text { serviços de água e } \\
\text { esgoto pela SABESP } \\
\text { até } 2018 .\end{array}$ & $\begin{array}{l}\text { - expansão e consoli- } \\
\text { dação das ocupações } \\
\text { residenciais irregu- } \\
\text { lares. }\end{array}$ & $\begin{array}{l}\text { - obra de infraestrutura urba- } \\
\text { na: pavimentação. } \\
\text { - construção de equipamentos } \\
\text { públicos, tais como: creches, } \\
\text { escolas e unidades básicas de } \\
\text { saúde; } \\
\text { - desenvolvimento do Plano } \\
\text { Municipal de Saneamento } \\
\text { Ambiental. }\end{array}$ \\
\hline
\end{tabular}




\begin{tabular}{|c|c|c|c|c|c|}
\hline $\begin{array}{l}\text { Unidades de } \\
\text { paisagens }\end{array}$ & $\begin{array}{l}\text { Características } \\
\text { físicas }\end{array}$ & Conflitos & $\begin{array}{l}\text { Cenários futuros } \\
\text { possíveis }\end{array}$ & $\begin{array}{l}\text { Cenários futuros } \\
\text { possíveis }\end{array}$ & $\begin{array}{l}\text { Principais projetos, planos } \\
\text { e ações públicas já execu- } \\
\text { tadas }\end{array}$ \\
\hline UP 03 & $\begin{array}{l}\text { - relevo plano; } \\
\text { - constitui-se na } \\
\text { Área de Proteção } \\
\text { Ambiental (APA) } \\
\text { da várzea do rio } \\
\text { Tietê; } \\
\text { - área de interesse } \\
\text { ecológico, am- } \\
\text { biental e paisa- } \\
\text { gístico; } \\
\text { - meandros e } \\
\text { fragmentos de } \\
\text { mata nativa bem } \\
\text { preservados; } \\
\text { - indústrias } \\
\text { implantadas na } \\
\text { Área de Proteção } \\
\text { Ambiental (APA) } \\
\text { da várzea do rio } \\
\text { Tietê; } \\
\text { - presença de cam- } \\
\text { pos e capoeiras. }\end{array}$ & $\begin{array}{l}\text { - indústrias concentradas } \\
\text { na Área de Proteção } \\
\text { Ambiental (APA) da } \\
\text { várzea do rio Tietê; } \\
\text { - Centro de Detenção } \\
\text { provisória (CDP), situa- } \\
\text { do na Área de Proteção } \\
\text { Ambiental (APA) da } \\
\text { várzea do rio Tietê; } \\
\text { - exploração mineral } \\
\text { com concessão de lavra } \\
\text { de argila e lavra de } \\
\text { cascalho; } \\
\text { - implantação de empre- } \\
\text { endimentos vinculados } \\
\text { à indústria, na Área de } \\
\text { Proteção Ambiental } \\
\text { (APA) da várzea do rio } \\
\text { Tietê, já licenciados; } \\
\text { - loteamentos consolida- } \\
\text { dos, na Área de Prote- } \\
\text { ção Ambiental (APA) da } \\
\text { várzea do rio Tietê, com } \\
\text { graves problemas de } \\
\text { drenagem. }\end{array}$ & $\begin{array}{l}\text { - implantação do } \\
\text { Parque Várzeas do } \\
\text { Tietê; } \\
\text { • conexão dos frag- } \\
\text { mentos de matas } \\
\text { existentes; } \\
\text { - ampliação das } \\
\text { potencialidades } \\
\text { paisagísticas; } \\
\text { - convivência da popu- } \\
\text { lação com a temática } \\
\text { ambiental; } \\
\text { - contemplação do } \\
\text { alto valor cênico; } \\
\text { - universalização dos } \\
\text { serviços de água e } \\
\text { esgoto pela SABESP } \\
\text { até } 2018 \text {. }\end{array}$ & $\begin{array}{l}\text { - extinção dos frag- } \\
\text { mentos de matas } \\
\text { existentes, devido a } \\
\text { ações antrópicas; } \\
\text { - ampliação da polui- } \\
\text { ção sanitária no rio } \\
\text { Tietê; } \\
\text { - ampliação da imper- } \\
\text { meabilização do solo, } \\
\text { a partir da instalação } \\
\text { de empreendimentos } \\
\text { vinculados à indús- } \\
\text { tria na várzea do rio } \\
\text { Tietê; } \\
\text { - a alça do Rodoanel } \\
\text { Leste será implan- } \\
\text { tada na Área de } \\
\text { Proteção Ambiental } \\
\text { (APA) da várzea do } \\
\text { rio Tietê. }\end{array}$ & $\begin{array}{l}\text { - projeto já elaborado do } \\
\text { Parque Várzeas do Tietê } \\
\text { pelo Governo do Estado de } \\
\text { São Paulo; } \\
\text { - desenvolvimento do Plano } \\
\text { Municipal de Saneamento } \\
\text { Ambiental. }\end{array}$ \\
\hline
\end{tabular}




\begin{tabular}{|c|c|c|c|c|c|}
\hline $\begin{array}{l}\text { Unidades de } \\
\text { paisagens }\end{array}$ & $\begin{array}{l}\text { Características } \\
\text { físicas }\end{array}$ & Conflitos & $\begin{array}{l}\text { Cenários futuros } \\
\text { possíveis }\end{array}$ & $\begin{array}{l}\text { Cenários futuros } \\
\text { possíveis }\end{array}$ & $\begin{array}{l}\text { Principais projetos, planos e } \\
\text { ações públicas já executadas }\end{array}$ \\
\hline UP 04 & $\begin{array}{l}\text { - relevo principal- } \\
\text { mente plano; } \\
\text { • ocupações } \\
\text { urbanas com bom } \\
\text { padrão de urba- } \\
\text { nização (sistema } \\
\text { viário, ilumina- } \\
\text { ção, saneamento, } \\
\text { espaços livres e } \\
\text { etc.); } \\
\text { - praças e parques } \\
\text { com usos defini- } \\
\text { dos; } \\
\text { - equipamentos ur- } \\
\text { banos, voltados à } \\
\text { saúde, educação, } \\
\text { cultura e etc.; } \\
\text { - áreas destinadas } \\
\text { à indústria; } \\
\text { - áreas de reflores- } \\
\text { tamento, campos, } \\
\text { chácaras e cultivo } \\
\text { de hortifrutigran- } \\
\text { jeiros. }\end{array}$ & $\begin{array}{l}\text { • exploração imobiliá- } \\
\text { ria latente; } \\
\text { • impermeabilização } \\
\text { do solo; } \\
\text { - sistema público de } \\
\text { drenagem deficien- } \\
\text { te; } \\
\text { - corpos d'água cana- } \\
\text { lizados; } \\
\text { - constantes enchen- } \\
\text { tes no período de } \\
\text { chuvas; } \\
\text { - calçadas e arboriza- } \\
\text { ção urbana inade- } \\
\text { quadas; } \\
\text { • poluição visual } \\
\text { nas fachadas dos } \\
\text { comércios. }\end{array}$ & $\begin{array}{l}\text { - implementação de } \\
\text { arborização urbana } \\
\text { adequada; } \\
\text { • implantação de } \\
\text { espécies arbóreas, ao } \\
\text { longo dos córregos } \\
\text { canalizados ou não; } \\
\text { - requalificação de } \\
\text { praças existentes; } \\
\text { - criação de calçadões; } \\
\text { - implementação } \\
\text { de infraestruturas } \\
\text { verdes; } \\
\text { - requalificação das } \\
\text { calçadas; } \\
\text { • ampliação do cam- } \\
\text { pus da Unipiaget e } \\
\text { do IFSP; } \\
\text { - universalização dos } \\
\text { serviços de água e } \\
\text { esgoto pela SABESP } \\
\text { até 2018. }\end{array}$ & $\begin{array}{l}\text { - diminuição das } \\
\text { espécies arbóreas } \\
\text { nas áreas urbani- } \\
\text { zadas; } \\
\text { - dificuldade de } \\
\text { acessibilidade } \\
\text { junto às calçadas; } \\
\text { - ausência de } \\
\text { manutenção das } \\
\text { calçadas. }\end{array}$ & $\begin{array}{l}\text { - planos de requalificação: Qua- } \\
\text { drilátero Central, Orla Ferroviá- } \\
\text { ria e Expansão do Centro; } \\
\text { - construção de equipamentos } \\
\text { públicos, tais como: Terminal } \\
\text { Vereador Diniz dos Santos Faria, } \\
\text { creches, centro de cultura, uni- } \\
\text { dades básicas de saúde, entre } \\
\text { outros; } \\
\text { - construção da Praça Cidade das } \\
\text { Flores } \\
\text { - reordenamento do trânsito; } \\
\text { - plano de limpeza urbana e } \\
\text { visual; } \\
\text { - projeto cicloviário para a aveni- } \\
\text { da João Batista Fitipaldi; } \\
\text { - construção do campus da } \\
\text { Unipiaget; } \\
\text { - construção do campus do IFSP; } \\
\text { - construção de vários equipa- } \\
\text { mentos no Parque Max Feffer; } \\
\text { Ambiental. }\end{array}$ \\
\hline
\end{tabular}




\begin{tabular}{|c|c|c|c|c|c|}
\hline $\begin{array}{l}\text { Unidades de } \\
\text { paisagens }\end{array}$ & $\begin{array}{l}\text { Características } \\
\text { físicas }\end{array}$ & Conflitos & $\begin{array}{l}\text { Cenários futuros } \\
\text { possíveis }\end{array}$ & $\begin{array}{l}\text { Cenários futuros } \\
\text { possíveis }\end{array}$ & $\begin{array}{l}\text { Principais projetos, planos e } \\
\text { ações públicas já executadas }\end{array}$ \\
\hline UP 05 & $\begin{array}{l}\text { - relevo pratica- } \\
\text { mente plano; } \\
\text { - diversas indús- } \\
\text { trias instaladas; } \\
\text { - áreas de reflores- } \\
\text { tamento, matas, } \\
\text { capoeiras e } \\
\text { campos; } \\
\text { - áreas de cháca- } \\
\text { ras; } \\
\text { - cultivo de horti- } \\
\text { frutigranjeiro; } \\
\text { - considerável } \\
\text { presença de vege- } \\
\text { tação de várzea } \\
\text { junto à Represa } \\
\text { de Taiaçupeba. }\end{array}$ & $\begin{array}{l}\text { - indústria junto à } \\
\text { área de várzea do rio } \\
\text { Tietê; } \\
\text { - grande área de ex- } \\
\text { ploração mineral; } \\
\text { - movimentação } \\
\text { de terra com solo } \\
\text { exposto. }\end{array}$ & $\begin{array}{l}\text { - criação de infraes- } \\
\text { trutura voltada ao } \\
\text { turismo; } \\
\text { - criação de parques } \\
\text { lineares; } \\
\text { • criação de corredo- } \\
\text { res ecológicos; } \\
\text { - potencialização do } \\
\text { alto valor cênico; } \\
\text { - universalização dos } \\
\text { serviços de água e } \\
\text { esgoto pela SABESP } \\
\text { até } 2018 .\end{array}$ & $\begin{array}{l}\text { - ampliação da imper- } \\
\text { meabilização do solo } \\
\text { próximo à várzea do } \\
\text { rio Tietê; } \\
\text { - expansão e consoli- } \\
\text { dação das ocupações } \\
\text { residenciais irregu- } \\
\text { lares. }\end{array}$ & $\begin{array}{l}\text { - construção de equipamentos } \\
\text { públicos, tais como: creches, } \\
\text { escolas, centro cultural, } \\
\text { unidades básicas de saúde, } \\
\text { entre outros; } \\
\text { - desenvolvimento do Plano } \\
\text { Municipal de Saneamento } \\
\text { Ambiental. }\end{array}$ \\
\hline
\end{tabular}

\begin{tabular}{|c|c|c|c|c|c|}
\hline $\begin{array}{l}\text { Unidades de } \\
\text { paisagens }\end{array}$ & $\begin{array}{l}\text { Características } \\
\text { físicas }\end{array}$ & Conflitos & \begin{tabular}{|l|}
$\begin{array}{l}\text { Cenários futuros } \\
\text { possíveis }\end{array}$ \\
\end{tabular} & \begin{tabular}{|l|}
$\begin{array}{l}\text { Cenários futuros } \\
\text { possíveis }\end{array}$ \\
\end{tabular} & $\begin{array}{l}\text { Principais projetos, planos e } \\
\text { ações públicas já executadas }\end{array}$ \\
\hline UP 06 & $\begin{array}{l}\text { - relevo plano nas } \\
\text { áreas ocupadas } \\
\text { e colinoso, nos } \\
\text { espaços onde a } \\
\text { maior parte da } \\
\text { vegetação de } \\
\text { mata nativa se } \\
\text { encontra; } \\
\text { - intenso cultivo } \\
\text { de hortifrutigran- } \\
\text { jeiro; } \\
\text { - área de interesse } \\
\text { ecológico, am- } \\
\text { biental e paisa- } \\
\text { gístico; } \\
\text { - diversos frag- } \\
\text { mentos de mata } \\
\text { nativa; } \\
\text { - áreas de campo e } \\
\text { capoeiras; } \\
\text { - pequena quan- } \\
\text { tidade de vege- } \\
\text { tação de várzea, } \\
\text { junto à bacia do } \\
\text { rio Guaió; } \\
\text { - poucas áreas de } \\
\text { chácaras. }\end{array}$ & $\begin{array}{l}\text { - movimentação } \\
\text { de terra com solo } \\
\text { exposto; } \\
\text { - desmatamentos } \\
\text { pontuais, caça ilegal } \\
\text { de animais silvestres; } \\
\text { - grandes áreas de } \\
\text { reflorestamento, } \\
\text { impostas entre os } \\
\text { fragmentos de matas } \\
\text { nativas. }\end{array}$ & $\begin{array}{l}\text { • criação de corredo- } \\
\text { res ecológicos; } \\
\text { • potencial para extra- } \\
\text { ção vegetal regular; } \\
\text { • universalização dos } \\
\text { serviços de água e } \\
\text { esgoto pela SABESP } \\
\text { até } 2018 .\end{array}$ & $\begin{array}{l}\text { - passagem do Rodoa- } \\
\text { nel Leste; } \\
\text { • expansão e consoli- } \\
\text { dação das ocupações } \\
\text { residenciais irregu- } \\
\text { lares. }\end{array}$ & $\begin{array}{l}\text { - desenvolvimento do Plano } \\
\text { Municipal de Saneamento } \\
\text { Ambiental. }\end{array}$ \\
\hline
\end{tabular}




\begin{tabular}{|c|c|c|c|c|c|}
\hline $\begin{array}{l}\text { Unidades de } \\
\text { paisagens }\end{array}$ & $\begin{array}{l}\text { Características } \\
\text { físicas }\end{array}$ & Conflitos & $\begin{array}{l}\text { Cenários futuros } \\
\text { possíveis }\end{array}$ & $\begin{array}{l}\text { Cenários futuros } \\
\text { possíveis }\end{array}$ & $\begin{array}{l}\text { Principais projetos, planos e } \\
\text { ações públicas já executadas }\end{array}$ \\
\hline UP 07 & $\begin{array}{l}\text { - relevo plano e } \\
\text { inclinado; } \\
\text { - grande presença } \\
\text { de chácaras; } \\
\text { - possui refloresta- } \\
\text { mento, capoeiras } \\
\text { e campos; } \\
\text { - cultivo de horti- } \\
\text { frutigranjeiro; } \\
\text { - proximidade } \\
\text { com a Represa de } \\
\text { Taiaçupeba. }\end{array}$ & $\begin{array}{l}\text { - ampliação da Repre- } \\
\text { sa de Taiaçupeba, } \\
\text { que irá propiciar a } \\
\text { retirada de: espaços } \\
\text { destinados ao cultivo } \\
\text { de hortifrutigranjei- } \\
\text { ros, além de matas, } \\
\text { campos e capoeiras; } \\
\text { - movimentação } \\
\text { de terra com solo } \\
\text { exposto; }\end{array}$ & $\begin{array}{l}\text { • instalação de estru- } \\
\text { turas turísticas; } \\
\text { • contemplação do } \\
\text { alto valor cênico; } \\
\text { • universalização dos } \\
\text { serviços de água e } \\
\text { esgoto pela SABESP } \\
\text { até } 2018 \text {. }\end{array}$ & $\begin{array}{l}\text { • ocupação urbana, } \\
\text { chácaras e cultivo de } \\
\text { hortifrutigranjeiro, } \\
\text { geram empecilhos } \\
\text { com relação à } \\
\text { implantação das } \\
\text { estruturas turísticas } \\
\text { compatíveis com este } \\
\text { espaço. }\end{array}$ & $\begin{array}{l}\text { - construção de equipamentos } \\
\text { públicos, tais como: creches, } \\
\text { escolas e unidades básicas de } \\
\text { saúde; } \\
\text { - execução de infraestrutura } \\
\text { urbana: pavimentação e } \\
\text { iluminação pública; } \\
\text { - desenvolvimento do Plano } \\
\text { Municipal de Saneamento } \\
\text { Ambiental. }\end{array}$ \\
\hline
\end{tabular}

\begin{tabular}{|c|c|c|c|c|c|}
\hline $\begin{array}{l}\text { Unidades de } \\
\text { paisagens }\end{array}$ & $\begin{array}{l}\text { Características } \\
\text { físicas }\end{array}$ & Conflitos & $\begin{array}{l}\text { Cenários futuros } \\
\text { possíveis }\end{array}$ & $\begin{array}{l}\text { Cenários futuros } \\
\text { possíveis }\end{array}$ & $\begin{array}{l}\text { Principais projetos, } \\
\text { planos e ações públicas } \\
\text { já executadas }\end{array}$ \\
\hline UP 08 & $\begin{array}{l}\text { - relevo colinoso; } \\
\text { - área de grande } \\
\text { interesse ecoló- } \\
\text { gico, ambiental e } \\
\text { paisagístico; } \\
\text { - intenso reflores- } \\
\text { tamento; } \\
\text { - chácaras recrea- } \\
\text { tivas; } \\
\text { - grandes frag- } \\
\text { mentos de matas } \\
\text { nativas; } \\
\text { - diversas áreas } \\
\text { de capoeiras e } \\
\text { campos; } \\
\text { - cultivo de horti- } \\
\text { frutigranjeiro. }\end{array}$ & $\begin{array}{l}\text { • ocupações urbanas; } \\
\text { • indústrias; } \\
\text { • exploração mineral; } \\
\text { - movimentação } \\
\text { de terra com solo } \\
\text { exposto; } \\
\text { - disposição irregular } \\
\text { de resíduos por mu- } \\
\text { nicípios vizinhos; } \\
\text { - desmatamentos } \\
\text { pontuais; } \\
\text { - maiores áreas vol- } \\
\text { tadas ao refloresta- } \\
\text { mento de eucalipto; } \\
\text { - caça ilegal de ani- } \\
\text { mais silvestres. }\end{array}$ & $\begin{array}{l}\text { • maiores possibilida- } \\
\text { des com relação à } \\
\text { criação de corredores } \\
\text { ecológicos; } \\
\text { • potencialização do } \\
\text { valor cênico; } \\
\text { • instalação de estru- } \\
\text { turas turístico-ecoló- } \\
\text { gica, junto à Represa } \\
\text { de Taiaçupeba; } \\
\text { - extração vegetal } \\
\text { regular; } \\
\text { • potencial para extra- } \\
\text { ção mineral regular; } \\
\text { • universalização dos } \\
\text { serviços de água e } \\
\text { esgoto pela SABESP } \\
\text { até } 2018 .\end{array}$ & $\begin{array}{l}\text { - extinção de significa- } \\
\text { tivos corpos d'água e } \\
\text { fragmentos florestais; } \\
\text { • pressões advindas da } \\
\text { agricultura; } \\
\text { - pressões advindas da } \\
\text { exploração mineral; } \\
\text { - interesse imobiliário } \\
\text { latente; } \\
\text { - expansão e consoli- } \\
\text { dação das ocupações } \\
\text { residenciais irregu- } \\
\text { lares, caracterizadas } \\
\text { como chácaras de } \\
\text { recreio. }\end{array}$ & $\begin{array}{l}\text { - construção de equipa- } \\
\text { mentos públicos: tais } \\
\text { como, creches, escolas } \\
\text { e unidades básicas de } \\
\text { saúde; } \\
\text { - desenvolvimento do } \\
\text { Plano Municipal de Sa- } \\
\text { neamento Ambiental. }\end{array}$ \\
\hline
\end{tabular}




\begin{tabular}{|c|c|c|c|c|c|}
\hline $\begin{array}{l}\text { Unidades de } \\
\text { paisagens }\end{array}$ & $\begin{array}{l}\text { Características } \\
\text { físicas }\end{array}$ & Conflitos & $\begin{array}{l}\text { Cenários futuros } \\
\text { possíveis }\end{array}$ & $\begin{array}{l}\text { Cenários futuros } \\
\text { possíveis }\end{array}$ & $\begin{array}{l}\text { Principais projetos, } \\
\text { planos e ações públicas } \\
\text { já executadas }\end{array}$ \\
\hline UP 09 & $\begin{array}{l}\text { - relevo acidentado; } \\
\text { - área de interesse } \\
\text { ecológico, ambien- } \\
\text { tal e paisagístico; } \\
\text { - presença de in- } \\
\text { dústrias, chácaras, } \\
\text { cultivo de hortifru- } \\
\text { tigranjeiro, frag- } \\
\text { mentos de mata } \\
\text { nativa, campos e } \\
\text { capoeiras. }\end{array}$ & $\begin{array}{l}\text { - presença de ocupa- } \\
\text { ções urbanas; } \\
\text { - desmatamentos } \\
\text { pontuais; } \\
\text { - caça de animais } \\
\text { silvestres; } \\
\text { - indústrias. }\end{array}$ & $\begin{array}{l}\text { - desenvolvimento de } \\
\text { interligações com os } \\
\text { demais fragmentos } \\
\text { de mata existentes } \\
\text { no entorno; } \\
\text { - criação de parques } \\
\text { lineares junto à Re- } \\
\text { presa de Taiaçupeba; } \\
\text { - universalização dos } \\
\text { serviços de água e } \\
\text { esgoto pela SABESP } \\
\text { até } 2018 .\end{array}$ & $\begin{array}{l}\text { - expansão e consoli- } \\
\text { dação das ocupações } \\
\text { residenciais irregu- } \\
\text { lares; } \\
\text { - extinção de significa- } \\
\text { tivos corpos d'água e } \\
\text { fragmentos florestais; } \\
\text { - contaminação dos } \\
\text { corpos d' água. }\end{array}$ & $\begin{array}{l}\text { - construção de equipa- } \\
\text { mentos públicos, tais } \\
\text { como: creches, escolas } \\
\text { e unidade básica de } \\
\text { saúde; } \\
\text { - desenvolvimento do } \\
\text { Plano Municipal de Sa- } \\
\text { neamento Ambiental. }\end{array}$ \\
\hline
\end{tabular}

\begin{tabular}{|c|c|c|c|c|c|}
\hline $\begin{array}{l}\text { Unidades de } \\
\text { paisagens }\end{array}$ & Características físicas & Conflitos & $\begin{array}{l}\text { Cenários futuros } \\
\text { possíveis }\end{array}$ & $\begin{array}{l}\text { Cenários futuros } \\
\text { possíveis }\end{array}$ & $\begin{array}{l}\text { Principais projetos, } \\
\text { planos e ações públi- } \\
\text { cas já executadas }\end{array}$ \\
\hline UP 10 & $\begin{array}{l}\text { - relevo parcialmente } \\
\text { plano e colinoso; } \\
\text { - área de interesse } \\
\text { paisagístico, ambiental } \\
\text { e ecológico; } \\
\text { - área lindeira à Represa } \\
\text { de Taiaçupeba; } \\
\text { - contém inúmeras áreas } \\
\text { voltadas às chácaras; } \\
\text { - apresenta a maior } \\
\text { quantidade com } \\
\text { relação ao cultivo de } \\
\text { hortifrutigranjeiro; } \\
\text { - diversas áreas de cam- } \\
\text { po, capoeira, fragmen- } \\
\text { tos de mata nativa e } \\
\text { vegetação de várzea; } \\
\text { - possui cultivo de eu- } \\
\text { calipto. }\end{array}$ & $\begin{array}{l}\text { - ocupações urbanas } \\
\text { desprovidas de sane- } \\
\text { amento; } \\
\text { - agricultura utilizan- } \\
\text { do-se com intensi- } \\
\text { dade dos recursos } \\
\text { hídricos; } \\
\text { - expansão da Repre- } \\
\text { sa de Taiaçupeba irá } \\
\text { gerar a supressão } \\
\text { de diversos tipos de } \\
\text { vegetação; } \\
\text { - fragmentos de mata } \\
\text { desconectados em } \\
\text { função das ativi- } \\
\text { dades vinculadas à } \\
\text { agricultura; } \\
\text { - desmatamentos } \\
\text { pontuais; } \\
\text { - caça ilegal de ani- } \\
\text { mais silvestres. }\end{array}$ & $\begin{array}{l}\text { • atividades vincula- } \\
\text { das ao turismo; } \\
\text { • incremento de } \\
\text { atividades voltadas } \\
\text { à pesca; } \\
\text { - valorização da } \\
\text { paisagem dado ao } \\
\text { alto valor cênico; } \\
\text { - implementação de } \\
\text { corredores ecoló- } \\
\text { gicos; } \\
\text { - universalização dos } \\
\text { serviços de água e } \\
\text { esgoto pela SABESP } \\
\text { até } 2018 \text {. }\end{array}$ & $\begin{array}{l}\text { • extinção de sig- } \\
\text { nificativos corpos } \\
\text { d'água e fragmen- } \\
\text { tos florestais; } \\
\text { - contaminação dos } \\
\text { corpos d'água; } \\
\text { - expansão e } \\
\text { consolidação das } \\
\text { ocupações residen- } \\
\text { ciais irregulares. }\end{array}$ & $\begin{array}{l}\text { - desenvolvimento do } \\
\text { Plano Municipal de } \\
\text { Saneamento Am- } \\
\text { biental. }\end{array}$ \\
\hline
\end{tabular}




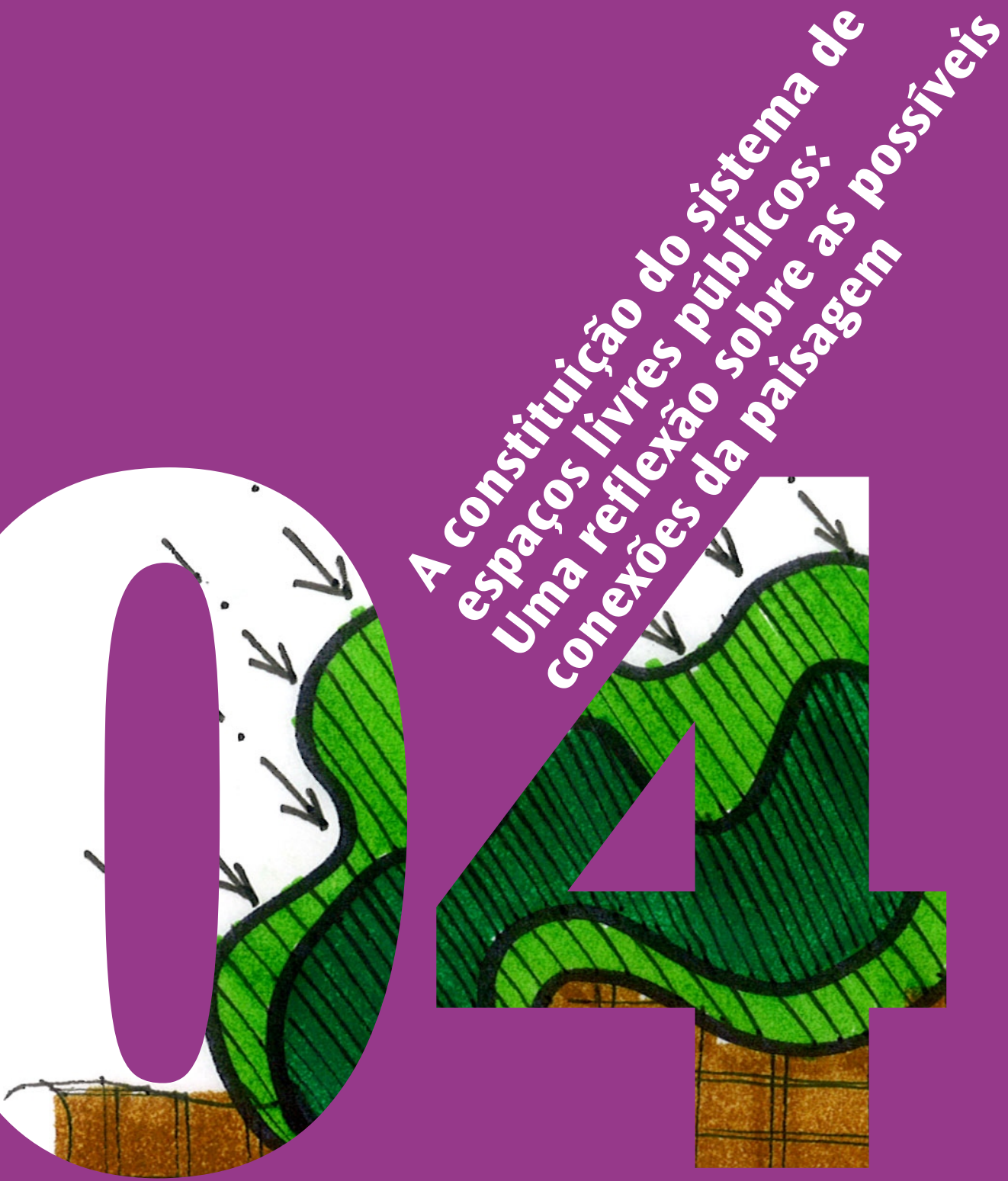





\section{Conexões da paisagem: Conceitos e análises}

É sob o viés de conceitos, tais como manchas, matrizes, bordas e, em especial, de conectividade, vinculados à ecologia de paisagens, já abordados no Capítulo 1, que este capítulo se desenvolve, objetivando elaborar propostas que visem a compreensão e a valorização do território a partir dos recursos naturais.

A análise do município mostra que, pouco a pouco, os fragmentos foram e ainda estão desaparecendo e que, portanto, se faz necessário criar planos, projetos e ações que sejam capazes de restabelecer, ainda que parcialmente, a estrutura do sistema natural antes existente, utilizando-se da ecologia de paisagens como instrumento.

Assim, entende-se que a paisagem de Suzano possui características que são sua própria assinatura, provenientes das formas naturais dos processos de crescimento e desenvolvimento; das pressões do mercado imobiliário para a constituição de habitação; da agricultura e do cultivo de eucalipto, que se impuseram sobre as manchas de vegetação natural, gerando sua supressão e fragmentação; da exploração mineral irregular e predatória; da implantação de indústrias junto a áreas que deveriam ter sido preservadas, como a várzea do rio Tietê; $\mathrm{e}$, da conivência, por parte do Poder Público, com relação às situações que degradaram este território, bem como pela falta de políticas públicas que buscassem a preservação, conservação e recuperação!

Mas, apesar de todas as pressões e degradações expostas, Suzano ainda possui potencial intrínseco para mudanças que visem a recuperação de sua paisagem e de seu ambiente, a partir de
IEm Suzano, as políticas públicas ambientais somente passaram a ser mais valorizadas a partir de 2005 , com a criação das diretorias de Meio Ambiente e Saneamento Ambiental, as quais se fundiram, posteriormente, na Diretoria de Saneamento e Gestão Ambiental, que fazia parte da Secretaria Municipal de Política Urbana. Mas, principalmente, as políticas vinculadas à agenda ambiental ganharam destaque a partir de 2009, com a criação da Secretaria Municipal de Meio Ambiente. 
2DRAMSTAD, W. E; OLSON, J. D.; FORMAN, R.T. T.. Landscape ecology principles in landscape architecture and land-use planning. Washington: Havard University, 1996. p. 14.

3lbid., p. 14. princípios que objetivem interligar as matas, as águas, as terras e a vida selvagem.

Compreender o mosaico existente no município, bem como as possibilidades de conexão de seus ecossistemas, é a base para que a paisagem possa ser novamente processada, mas desta vez para conseguir a recuperação de suas florestas e águas.

É a partir da ilustração de alguns conceitos-chave, ligados à ecologia de paisagens, que compreenderemos o território, utilizando-os para o planejamento de soluções, vinculados ao uso da terra.

Para tanto, o conceito voltado à ecologia de paisagens a ser aplicado indica três características:

- funcionalidade - é o movimento e o fluxo de animais, plantas, água, vento, materiais e energia, através da estrutura;

- mudança - é a dinâmica ou alteração em padrão espacial e tempo de funcionamento;

- $\quad$ estrutura - é o padrão espacial ou arranjo de elementos de paisagem ${ }^{2}$.

0 padrão estrutural de uma paisagem é composto por três tipos de elementos: manchas, corredores e matrizes. É através do entendimento da forma como eles se situam no território que se passa a entender a paisagem, podendo se utilizar dos conceitos vinculados à ecologia de paisagens no planejamento do uso do solo ${ }^{3}$.

Dessa forma, os esquemas a serem apresentados e utilizados para o entendimento, bem como para a formulação de propostas voltadas à paisagem do território de Suzano são: matriz, manchas, corredores ecológicos e conectividade, stepping stones e bordas. 


\section{Matriz}

A matriz é uma unidade de paisagem que estrutura a dinâmica ecológica de um determinado setor da paisagem, podendo ser considerada natural (no caso de grandes fragmentos de mata) ou de urbanização (quando se trata da cidade) ${ }^{4}$.
${ }^{4}$ METZGER J. P.. o que é ecologia de paisagens?. In: Biota Neotropica, v.1 (n.1). BN00701122001, 2001. p.8. www.biotaneotropica.org.br/v1n12/ pt/fullpaper?bn00701122001+pt. Acesso em: 14 de jan. 2012.

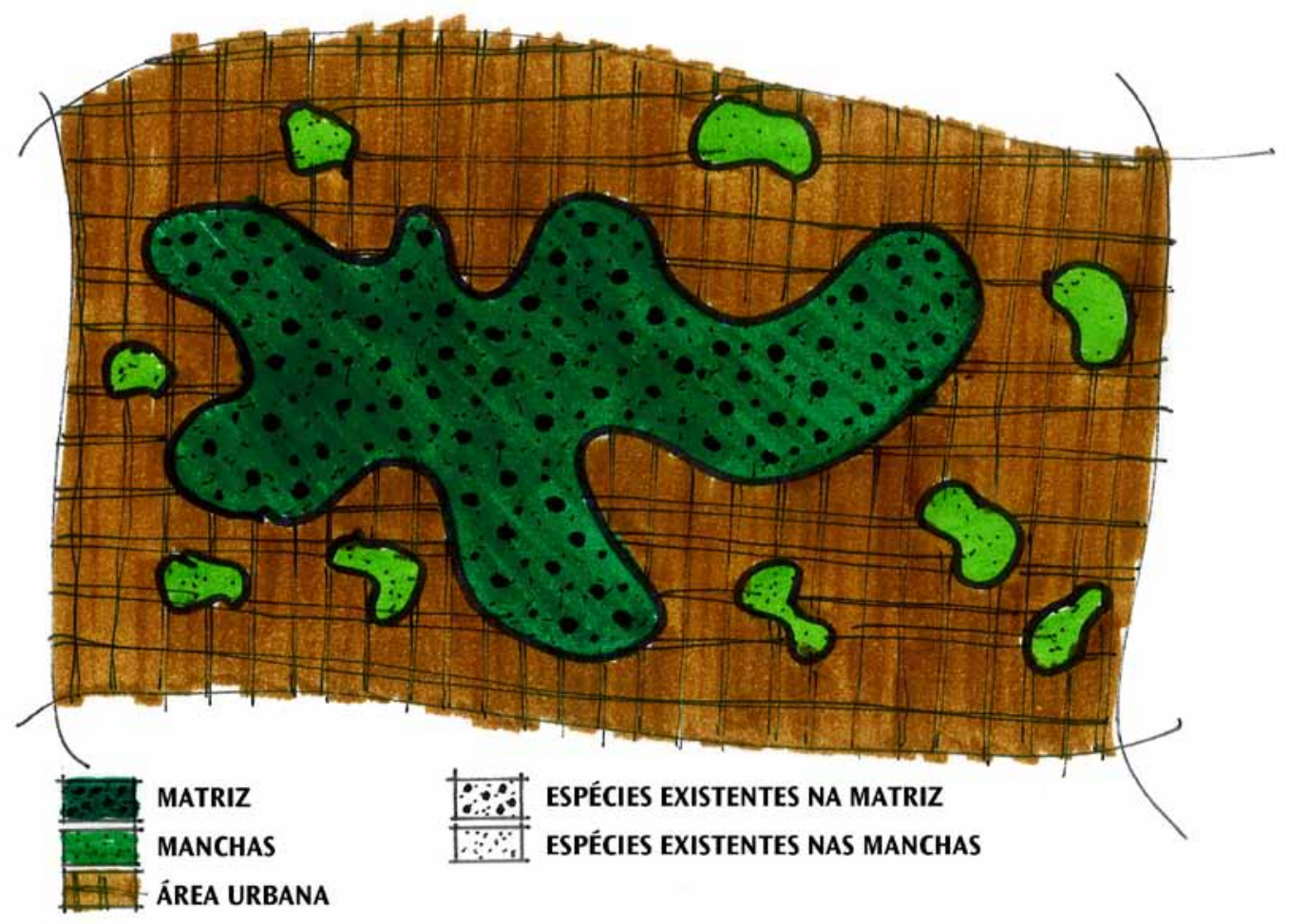

Matriz 01: A matriz é caracterizada pela máxima complexidade funcional e ambiental, além de possuir grandes extensões lineares, sendo que, em geral, é reconhecida por recobrir a maior parte da paisagem Fonte: Desenho criado por Michele de Sá Vieira, 2012 


\section{Manchas}

5Ibid., p. 8.

Mancha 01: Dividindo uma grande mancha em duas menores, removese o interior do habitat reduzindo-se o número de espécies, as quais teriam importância na conservação do ambiente Fonte: Desenho criado por Michele de Sá Vieira, 2012
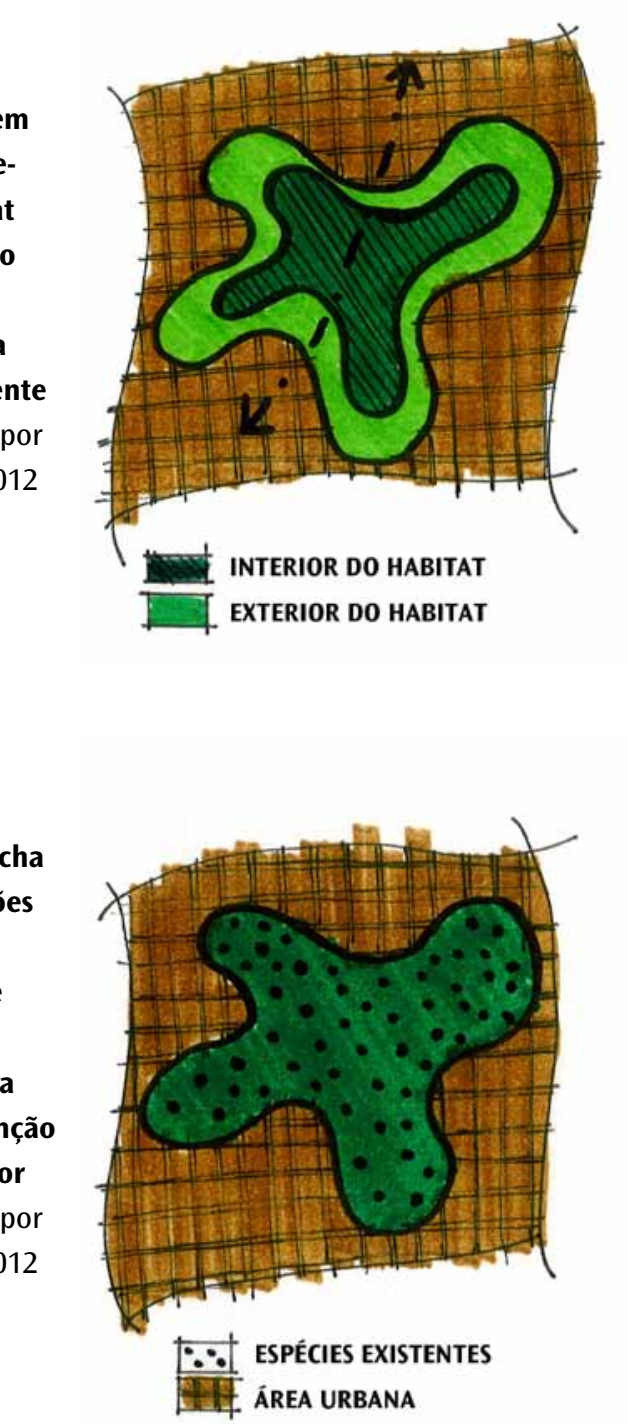

Mancha 02: Uma mancha com maiores proporções possui um número maior de espécies que uma mancha menor. Este fato faz com que a probabilidade de extinção das espécies seja menor Fonte: Desenho criado por Michele de Sá Vieira, 2012 urbanizada.

As manchas são consideradas as áreas homogêneas de uma unidade da paisagem, possuindo extensões espaciais reduzidas e não-lineares ${ }^{5}$. Os esquemas a seguir ilustram as diversas possibilidades de configuração das manchas situadas sobre área

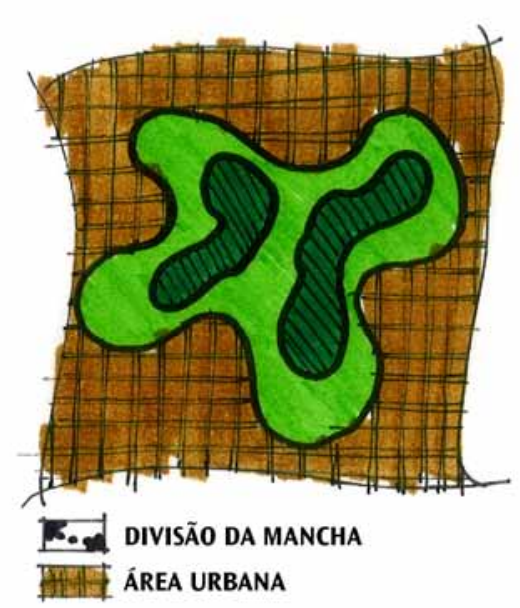




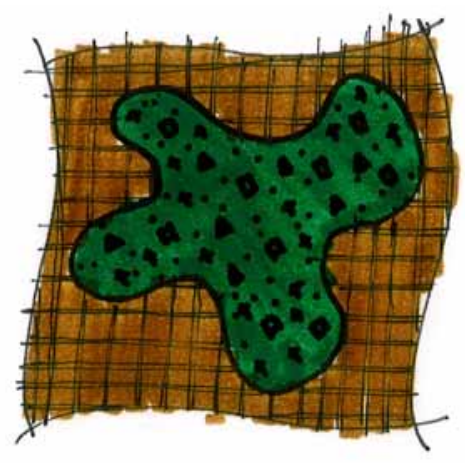

ESPÉCIES EXISTENTES EM UMA MANCHA MAIOR $\because$ ESPÉcIes EXISTENTES EM UMA MANCHA MENOR

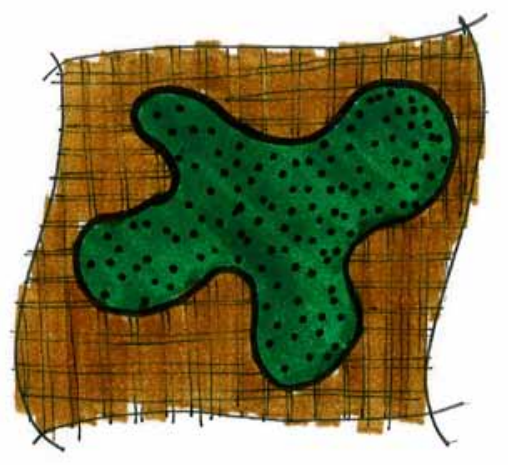

\section{$\because \because$ QUANTIDAde de ESPÉCIES Na MANCHA 整 ÁREA URBANA}

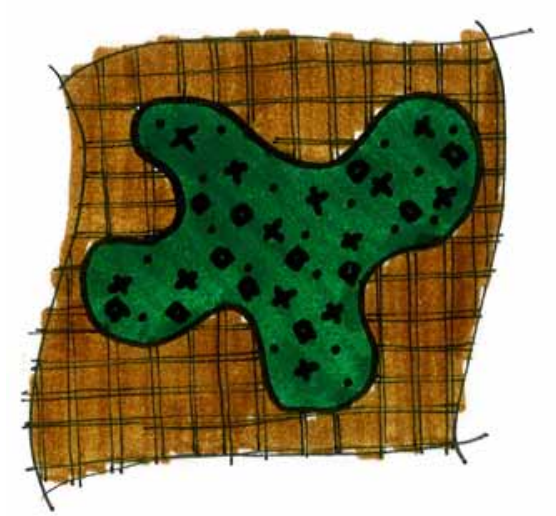

Mancha 03: Uma mancha grande tem chance de ter mais espécies presentes do que uma mancha menor

Fonte: Desenho criado por Michele de Sá Vieira, 2012

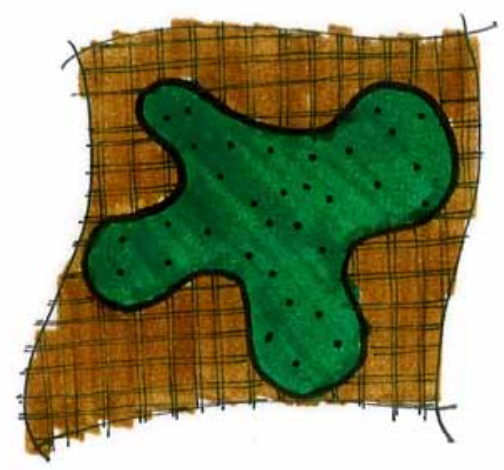

Mancha 04: A probabilidade de espécies se tornarem localmente extintas é maior se a mancha tiver uma quantidade de espécies menor, além disso, quanto maior a diversidade de espécies, mais chances de perpetuação ela terá

Fonte: Desenho criado por Michele de Sá Vieira, 2012

\begin{abstract}
FT:- DIVERSIDADE DE ESPÉCIES MAIOR EM UMA MANCHA
DIVERSIDADE DE ESPÉCIES MENOR EM UMA MANCHA

ÁREA URBANA
\end{abstract}


Mancha 05: A remoção de manchas causa perda de habitat, este fato traz como consequência a redução da quantidade das populações de espécies, bem como a diminuição da diversidade deste habitat

Fonte: Desenho criado por Michele de Sá Vieira, 2012

Mancha 06: Uma mancha, localizada próxima a outra no "espaço principal", tem possibilidades maiores de ser colonizada ou de recolonizar, do que manchas que estejam em locais mais distantes Fonte: Desenho criado por Michele de Sá Vieira, 2012

Mancha 07: Uma mancha ecologicamente ótima, capaz de prover inúmeros benefícios ecológicos, é geralmente "moldada espacialmente" com um centro circular para a proteção de recursos, possui alguns limites curvilíneos e poucas "pontas" para dispersão das espécies

Fonte: Desenho criado por Michele de Sá Vieira, 2012
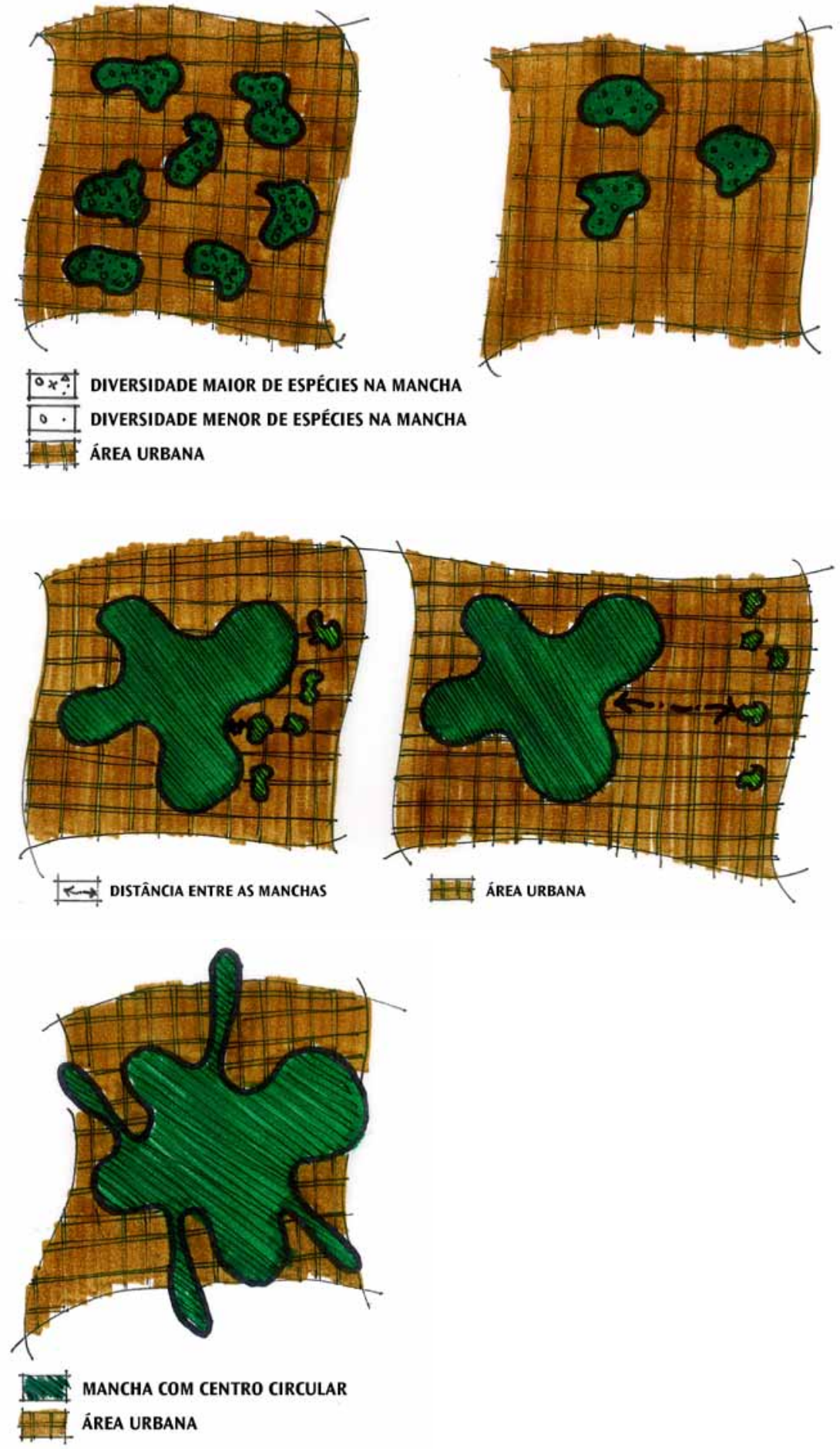


\section{Corredores ecológicos e conectividade}

Os corredores são áreas homogêneas em uma determinada escala de uma unidade da paisagem, apresentando disposição espacial linear que liga dois fragmentos, além disso, são avaliados no que se refere a sua largura e continuidade e também quanto ao fato de serem retos ou curvilíneos ${ }^{6}$.

Por sua vez, conectividade é a capacidade que a estrutura da paisagem, ou que as unidades da paisagem, possuem de facilitar os fluxos biológicos. Assim, o sucesso com relação à conectividade depende da proximidade dos elementos do habitat, da densidade dos corredores, quantidade de stepping stones, bem como da permeabilidade da matriz, seja ela natural ou urbanizada 7 .

Muitos processos dinâmicos, tais como a instalação das ocupações urbanas e/ou de distúrbios naturais como incêndios e invasões herbivoras, entre outros, geram impactos que desconectam unidades de paisagens, como os fragmentos florestais, provocando resultados como a:

- fragmentação - quebra de um habitat intacto;

- dissecação - criação de "buracos" dentro de um habitat essencialmente intacto;

- perfuração - diminuição no tamanho de um habitat ou mais;

- extinção - desaparecimento de uma ou mais manchas de habitats 8 .

Ou seja, em função de contínuas perdas e isolamentos de habitats, muitos ecologistas de paisagens sugerem a necessidade de promover a conectividade de paisagens através de corredores e stepping stones.
6Ibid., p. 7.

${ }^{7}$ lbid., p. 7.

8 DRAMSTAD, W. E; OLSON, J. D.; FORMAN, R.T. T.. Landscape ecology principles in landscape architecture and land-use planning. Washington: Havard University, 1996. p. 35 
${ }^{9}$ lbid., p. 35.

10 Ibid., p. 35.

II Ibid., p. 41.

I2Ibid., p. 41.

Apesar das discussões que acontecem questionando quanto a real eficácia e capacidade que os corredores possuem em aumentar a biodiversidade, a conclusão que se chega é que estes realmente trazem benefícios reais para os habitats 9 .

Alguns tipos de corredores, a exemplo das rodovias, trilhos de trens, linhas de alta tensão, podem funcionar como barreiras e não como elementos de interligação e manutenção dos habitats. Mas há, também, aqueles que possuem excepcional significado para a paisagem e que contribuem de maneira significativa para a manutenção e ampliação da integridade ecológica, como os riachos e os rios 10 .

Para tanto, determinadas caracteristicas do sistema hídrico, tais como a largura, a extensão, a existência da mata ciliar ao longo dele, bem como sua continuidade, é que irão definir a sua capacidade em promover boas conexões, ou seja, todos os aspectos comentados acabam por interferir nas condições aquáticas como as temperaturas da água e o alto nivel de oxigênio que interferem diretamente no trânsito das populações aquáticas e, consequentemente, na capacidade de realizar as conexões'I.

Os corredores, além de conectarem fragmentos de mata não lineares, como as manchas e as matrizes, também se interconectam criando circuitos que contribuem com o funcionamento das paisagens, por facilitar e ampliar os fluxos de energia dentro de um território ${ }^{12}$. 

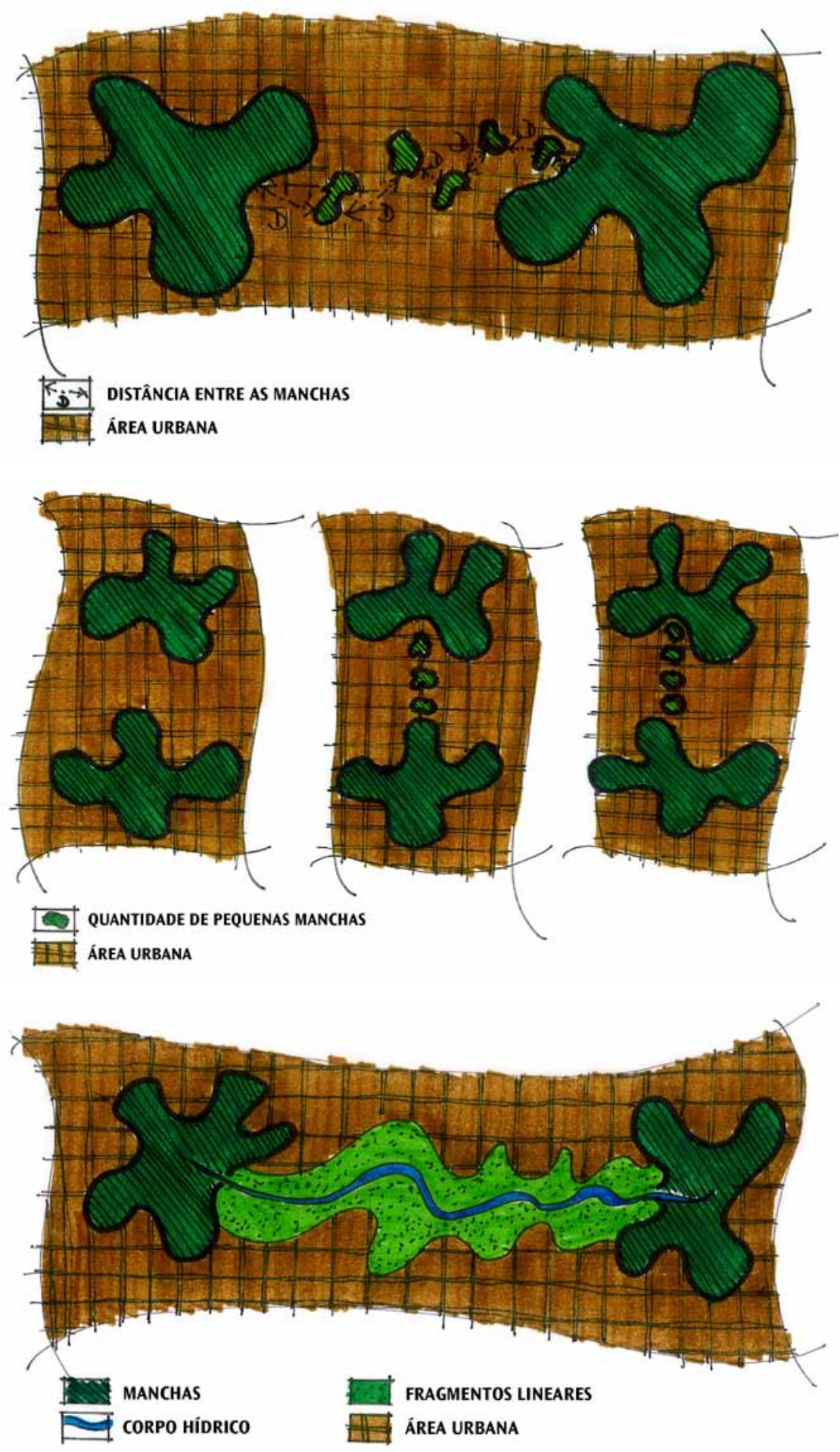

Corredor ecológico 01: Para espécies que se orientam através da visão, a distância efetiva a ser percorrida é determinada pela habilidade de ver cada mancha sucessivamente, ou seja, quanto mais próximas elas estiverem com maior facilidade as espécies irão se movimentar Fonte: Desenho criado por Michele de Sá Vieira, 2012

Corredor ecológico 02: Quanto maior for a quantidade de pequenas manchas entre fragmentos maiores, maior será a probabilidade de acontecer a conectividade Fonte: Desenho criado por Michele de Sá Vieira, 2012

\section{Corredor ecológico 03:} Os corpos d' água devem ser utilizados para fazer as conexões através dos fragmentos situados em suas margens, ou a serem implementados, em função da capacidade que possuem em promover interligações Fonte: Desenho criado por Michele de Sá Vieira, 2012 
13 METZGER J. P.. o que é ecologia de paisagens?. In: Biota Neotropica, v.1 (n.1), BN00701122001, 2001. p.8. www.biotaneotropica.org.br/v1n12/ pt/fullpaper?bn00701122001+pt. Acesso em: 14 de jan. 2012.
Stepping stones 01: As manchas pequenas, que se colocam entre as manchas maiores, agem como "pontos de apoio" para 0 movimento das espécies Fonte: Desenho criado por Michele de Sá Vieira, 2012

\section{Stepping Stones}

Os stepping stones, "pontos de ligação" ou "trampolins ecológicos", são pequenos espaços de habitat como parques, manchas, maciços de vegetação, praças, etc., dispersos pela matriz, que podem ser as áreas urbanizadas, os campos, bem como os locais de cultivo agrícola. Estes pontos de ligação são pequenos fragmentos utilizados para restabelecer a continuidade quando outras formas são inviáveis ${ }^{13}$.

Stepping stones 02: A melhor disposição para um conjunto de stepping stones entre grandes manchas é situá-lo de forma linear. Além disso, é importante que seja posto de maneira a oferecer rotas alternativas para as espécies Fonte: Desenho criado por Michele de Sá Vieira, 2012
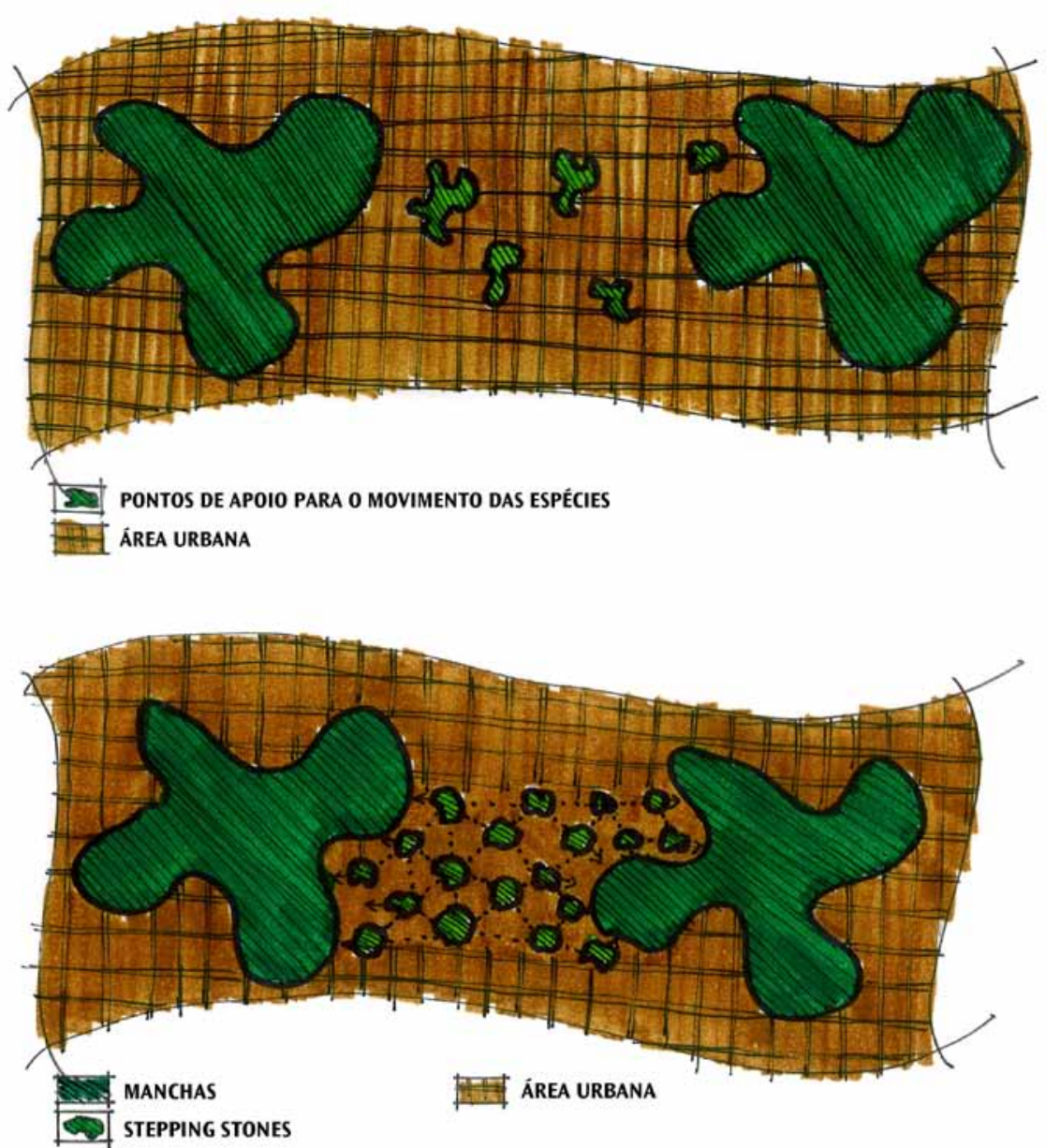


\section{Bordas}

A borda é a porção externa da mancha, que se difere do seu interior em vários aspectos, como: a largura, a quantidade e a composição de espécies, a estrutura vertical e horizontal, o fluxo de energia dos nutrientes, entre outros 14 .

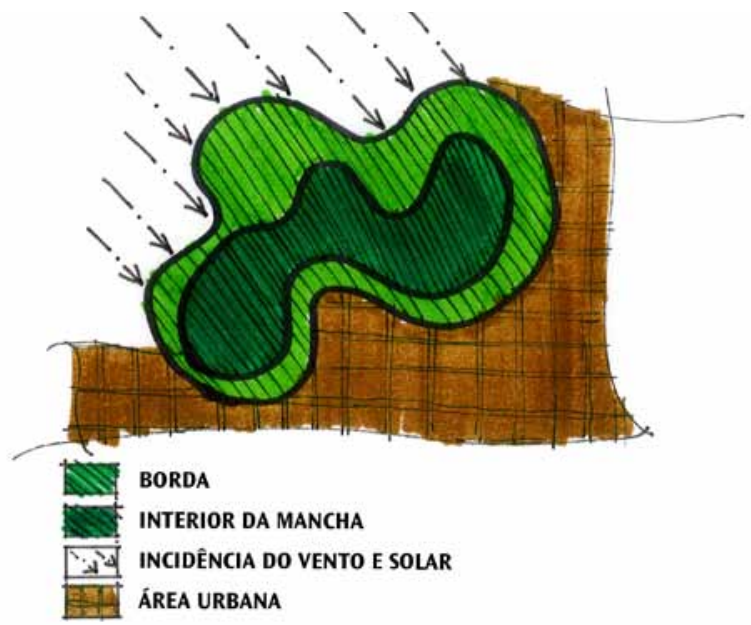

Borda 01: A largura da borda difere em torno da mancha, em função da direção do vento e da exposição solar, em geral a incidência destes fatores contribui para que a borda seja mais larga Fonte: Desenho criado por Michele de Sá Vieira, 2012

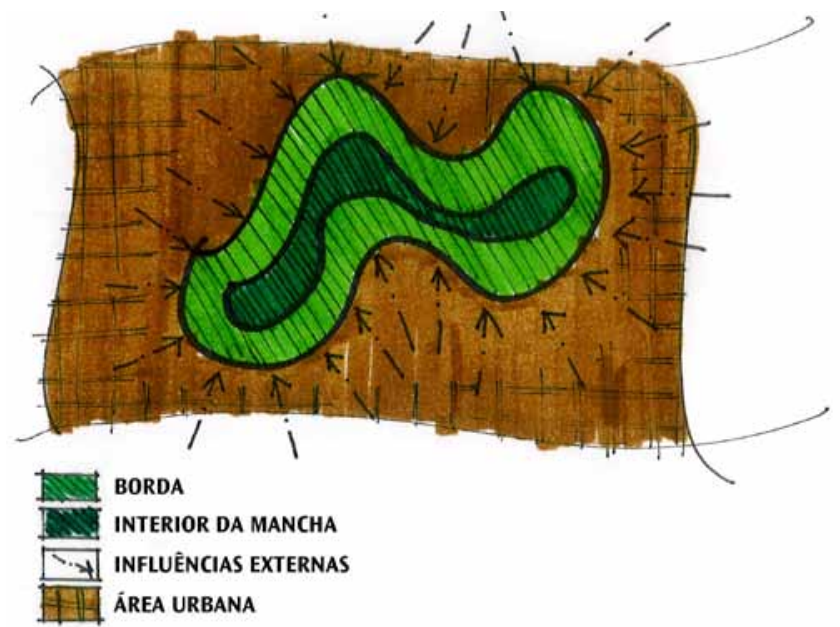

Borda 02: As bordas também funcionam como filtros, impedindo que influências externas cheguem ao interior das manchas, matrizes e corredores Fonte: Desenho criado por Michele de Sá Vieira, 2012

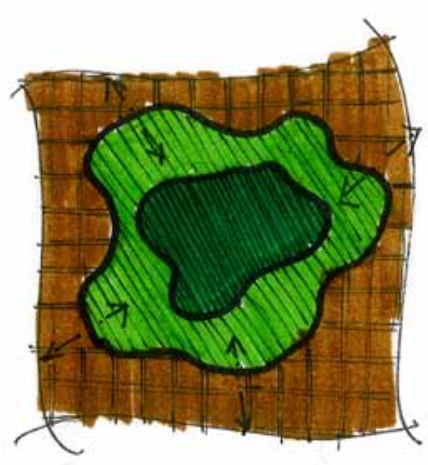

BORDA INTERIOR DA MANCHA

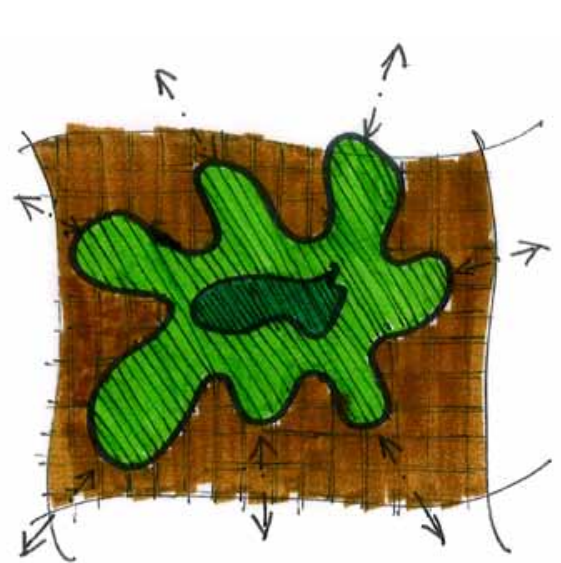

F. INTERAÇÕES COM O ENTORNO

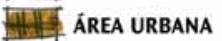

Borda 03: Uma mancha com formato mais irregular terá maior proporção de habitat de borda que uma mancha com formato mais homogêneo, consequentemente, o número de espécies do interior, inclusive aquelas de importante conservação, será menor neste elemento, que apresenta mais "pontas". Além disso, quanto mais irregular for a forma da mancha, maior a interação, ora positiva, ora negativa, entre esta e seu entorno Fonte: Desenho criado por Michele de Sá Vieira, 2012 
15Ibid., p. 8.

16/bid., p. 8.
Assim, ao perpassar pelos diversos conceitos, verifica-se que a utilização da ecologia de paisagens pode propiciar a resolução de problemas ambientais, os quais requerem um trabalho de planejamento em grupo, ou seja, por especialistas como os arquitetos, dado ao fato de possuírem conhecimento vinculado ao uso do solo, e ecologistas, em função de compreenderem os processos ecológicos, objetivando, dessa forma, construir um trabalho interdisciplinar, através do desempenho de ambos os grupos ${ }^{15}$.

Além disso, entende-se que a ecologia de paisagens é uma ferramenta simples, para que os gestores ambientais possam utilizá-la como um instrumento de implantação de políticas públicas ambientais, a partir da compreensão de que este conceito pode auxiliar, em determinados momentos, as decisões do Poder Público, por exemplo, quando este resolve acrescentar ruas, preservar reservas naturais e inserir habitações. Ou seja, contribuir no sentido de maximizar a integridade ecológica, minimizando a degradação do solo, já que colabora para que sejam reduzidas as fragmentações tão evidentes em cada território ${ }^{16}$.

Para que se possa avançar com propostas voltadas às conexões florestais a serem estabelecidas no território de Suzano, analisa-se algumas das suas caracteristicas físicas relacionadas às concentrações de vegetação nativa, na APA e na APM, nas bacias hidrográficas do território, além de abordar questões vinculadas aos recursos hídricos, todos sob a ótica das potencialidades e dos conflitos. 


\section{Vegetação: Concentrações junto a APA e a APM}

Sabe-se que parte dos fragmentos naturais do território foram suprimidos, apesar disso, quando o comparamos com os demais que compõem a Região Metropolitana de São Paulo, constata-se que ainda existem muitos estoques naturais compostos por remanescentes de vegetação de Mata Atlântica, especialmente dentro da Área de Proteção Ambiental (APA) e da Área de Proteção dos Mananciais (APM), que ainda se encontram bastante integros, com alta qualidade ambiental, podendo ser utilizados para as possiveis conexões na paisagem, tanto dentro de Suzano, quanto com os municípios vizinhos ${ }^{17}$.
${ }^{17}$ A Lei Estadual n. 5.598, de 6 de fevereiro de 1987, declara Área de Proteção Ambiental regiões urbanas e/ou rurais dos Municípios de Salesópolis, Biritiba Mirim, Moji das Cruzes, Suzano, Poá, Itaquaquecetuba, Guarulhos, São Paulo, Osasco, Barueri, Carapicuíba e Santana do Parnaíba. Além disso, a Área de Proteção Ambiental é prevista no Sistema Nacional de Unidades de Conservação SNUC - Lei Federal n. 9.985/2000, em seu Art.15, que define a APA como uma área em geral extensa, com um certo grau de ocupação humana, dotada de atributos abióticos, bióticos, estéticos ou culturais, especialmente importantes para a qualidade de vida e o bem-estar das populações humanas. 
Mapa localizando a APA e a APM

\section{em Suzano}

Fonte: Desenho criado por Michele de Sá Vieira, 2011 baseado em mapa (T-3, cobertura vegetal e uso do solo) da Prefeitura Municipal de Suzano PMS, 2008

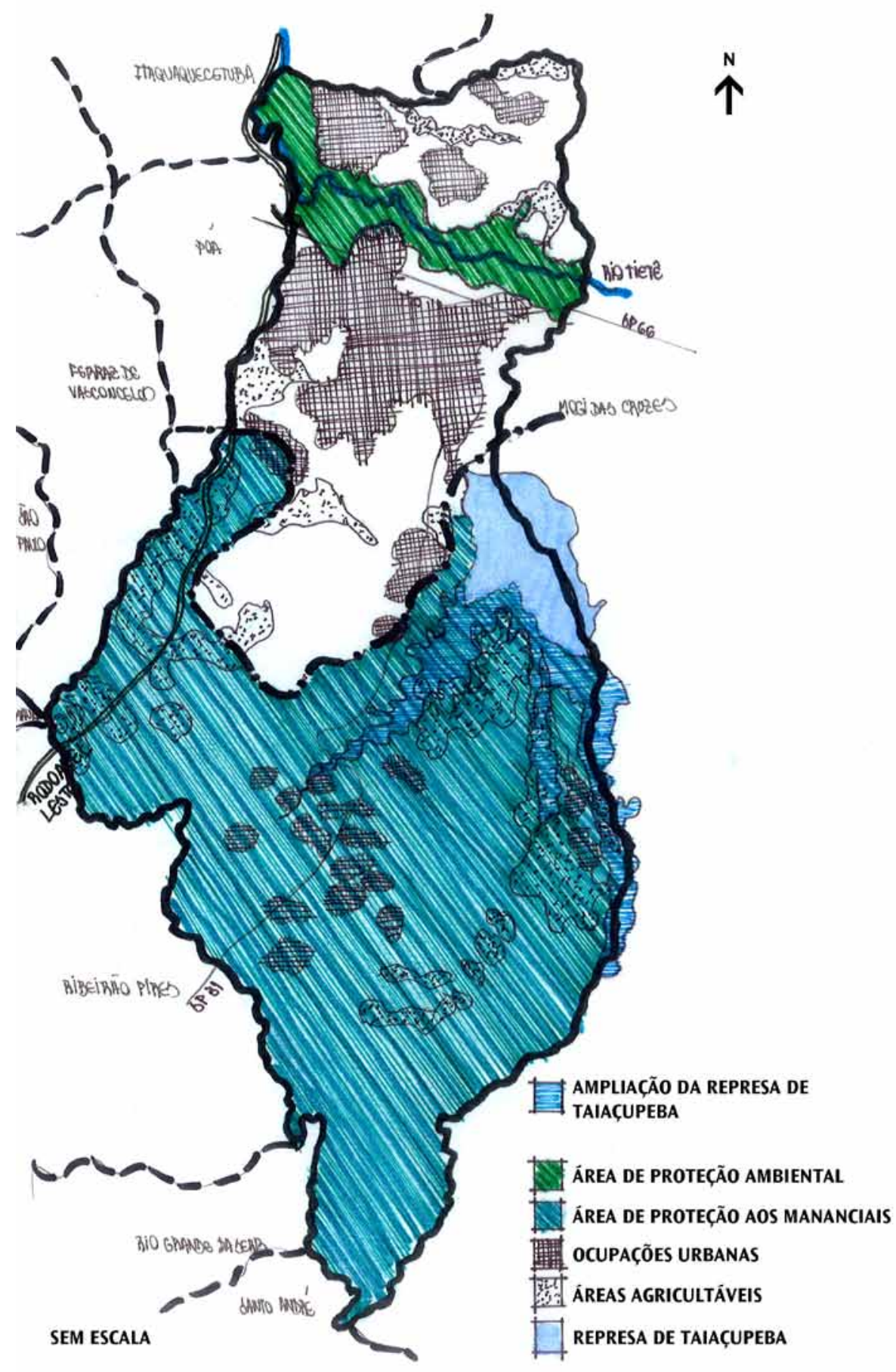




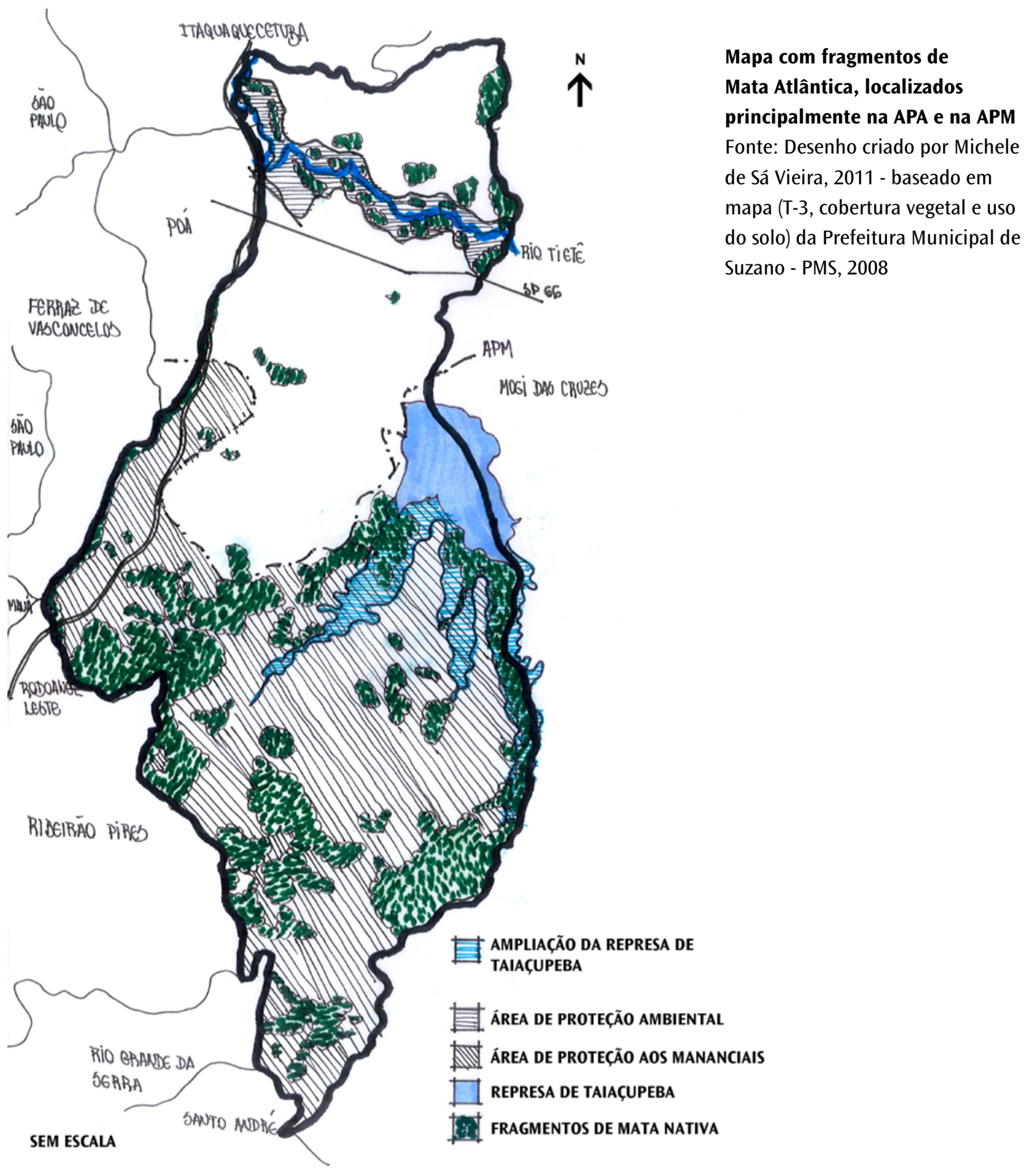




\section{Vegetação: Concentrações junto às bacias hidrográficas}

18É importante ressaltar que, embora estas duas bacias guardem significativos fragmentos, ainda em 2012, parte delas serão suprimidas, respectivamente, em função das obras do Rodoanel Leste e da ampliação da Represa de Taiaçupeba.
Boa parte dos fragmentos de Suzano está localizada principalmente junto às várzeas dos rios Guaió e Taiaçupeba, embora a bacia do Tietê-Leste ainda guarde grandes concentrações de recursos, em função da várzea do Tietê estar conservada.

Já no extremo norte do território existe uma quantidade expressiva, mas fragmentada, de vegetação, que se concentra principalmente no Parque Mirante do Tietê e junto à divisa com o município de Mogi das Cruzes.

Observa-se, ainda, que ao sul da bacia do Guaió, embora parte da vegetação esteja seccionada, a existência dos corpos hídricos, sem dúvida, poderia facilitar diversas interligações entre as matas. A mesma leitura se faz para a bacia do Taiaçupeba, no que se refere à conexão dos fragmentos, que é mais intensa, dado ao fato de possuir maior abundância com relação aos recursos naturais voltados às águas e às matas ${ }^{18}$.

A partir da análise destes potenciais, procura-se dar pistas de como as conexões poderiam ser realizadas através das bacias, levando-se em consideração os diversos fragmentos de mata existentes:

- os da bacia do Tietê-Leste possuem alto potencial para se conectar à vegetação de Mogi das Cruzes;

- os da bacia do Guaió iriam se interligar aos de Ferraz de Vasconcelos, Mauá e Ribeirão Pires;

- $\quad$ os da bacia do Taiaçupeba se juntariam aos de Rio Grande da Serra, Santo André e Mogi das Cruzes. 


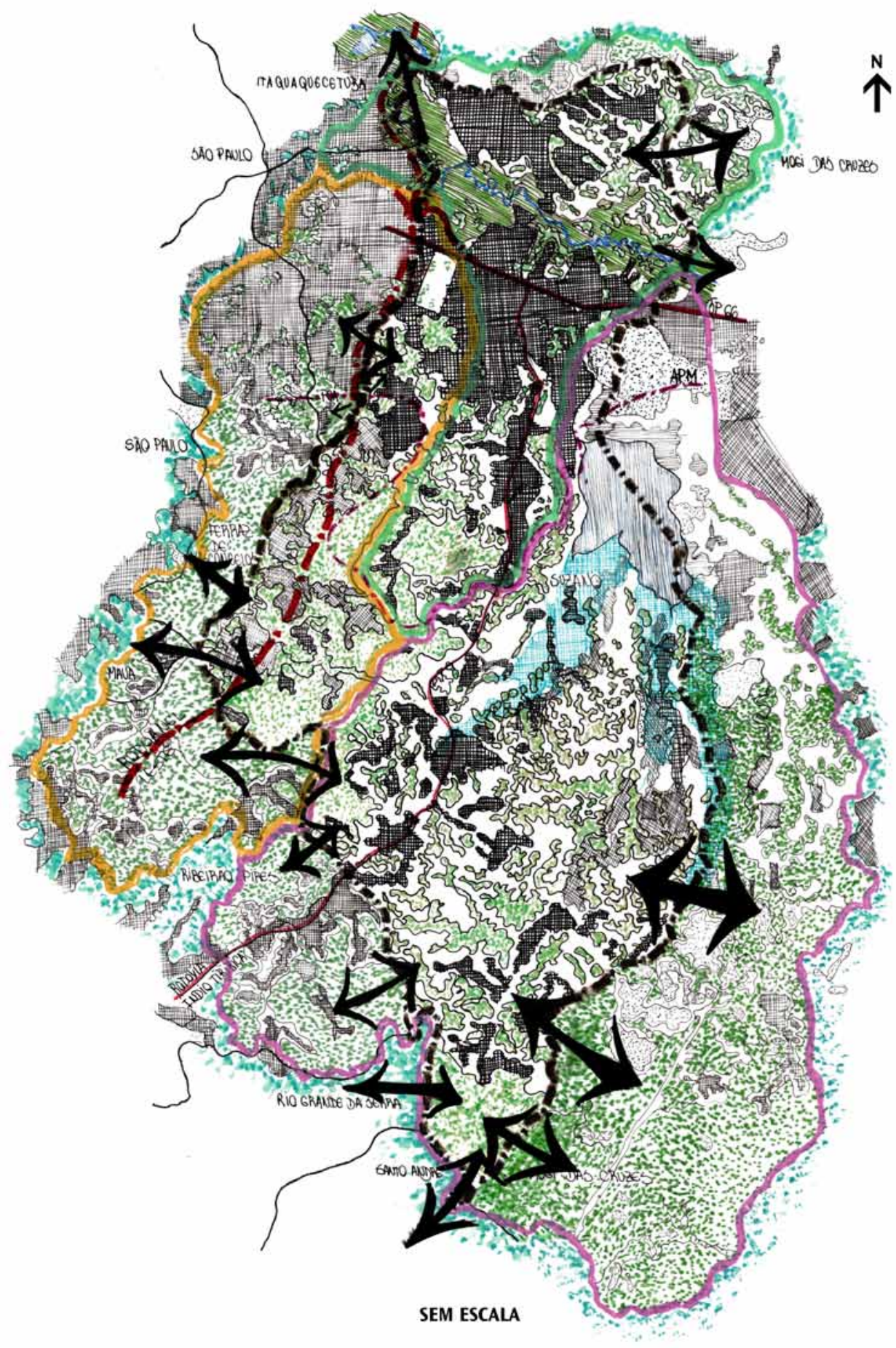

Mapa que aponta como os fragmentos florestais existentes nas três bacias de Suzano podem se conectar, com os municípios vizinhos Fonte: Desenho criado por Michele de Sá Vieira, 2011 baseado em mapa do Plano de Macrodrenagem (T-3, base de imagens aéreas para a delimitação das bacias de estudo) da Prefeitura Municipal de Suzano - PMS, 2008 e mapa de Uso e Ocupação do Solo da Empresa Paulista de Planejamento Metropolitano EMPLASA, 2006

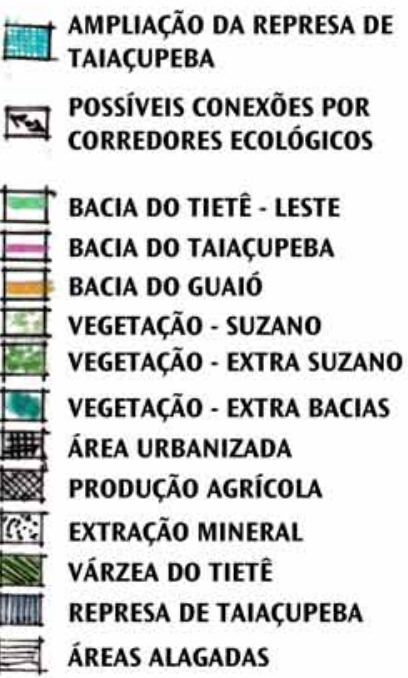




\section{Recursos hídricos: Potencialidades e conflitos}

Embora o território possua rico sistema hídrico, observa-se, claramente, as intervenções que as ocupações urbanas propiciaram junto aos corpos d'água, principalmente na bacia do Tietê-Leste, bem como na bacia do Taiaçupeba, interferindo assim nos ecossistemas.

Quanto à bacia do Guaió, esta não é intensamente afetada no que se refere à existência das ocupações urbanas, considerando-se que elas se encontram em maior quantidade e porte nas bacias do Tietê-Leste e Taiaçupeba.

Por outro lado, notamos a forte exploração da agricultura nesta bacia, o que remete a uma grande utilização com relação aos recursos hídricos. Tal fato se estende também para a bacia do Taiaçupeba, onde esta atividade ocupa importantes extensões do território.

Outra questão de grande relevância é a passagem do Rodoanel Leste pela bacia do Guaió, o qual irá propiciar, a partir de 2012, ano inicial das suas obras, impactos no sistema hídrico.

Assim, o que se observa é que, por diversas razões, os recursos hidricos foram extremamente comprometidos em todas as bacias hidrográficas do município. No entanto, pode-se verificar que eles ainda se encontram bastante ricos, com relação à quantidade. 


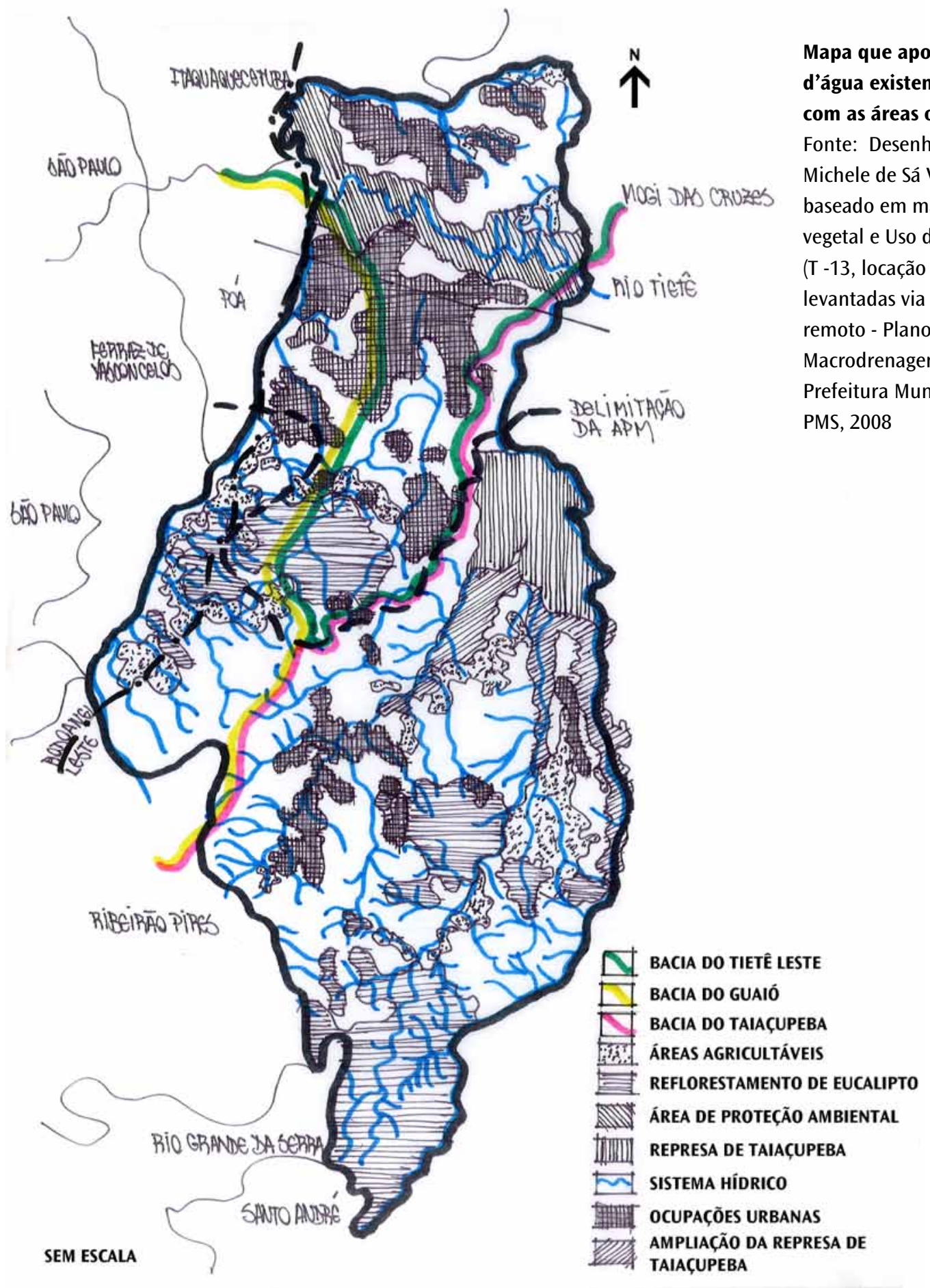




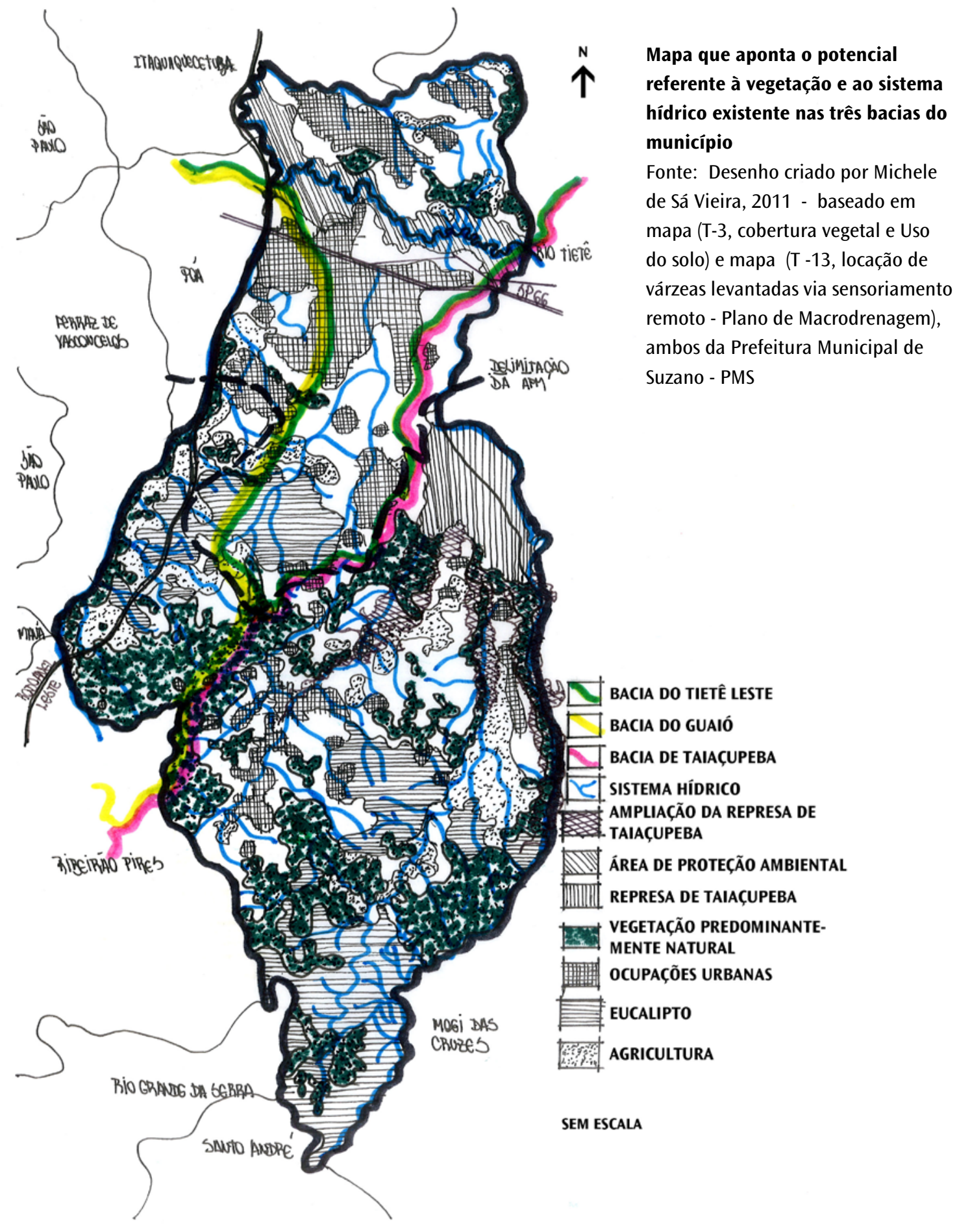


Entende-se, ainda, que a degradação existente especialmente no que se refere à qualidade da água, a exemplo da bacia do Tietê-Leste, não se dá apenas em Suzano, mas também em outros territórios.

Para tanto, segue análise referente a seis pontos distintos, por onde o Rio Tietê passa, localizados entre Salesópolis e GuaruIhos, os quais permitem uma verificação com relação à qualidade da água. Para tanto, foram levantados os seguintes dados:

- $\quad \mathrm{pH}-$ índice do potencial hidrogeniônico, o qual indica a acidez, sendo que o pH normal está entre 6,0 e 8,0;

- OD - índice de oxigênio dissolvido, o qual indica o índice de poluição, sendo que o OD normal está entre 6,0 e 10,0;

- temperatura, a qual é considerada normal até $40,0^{\circ}$.

\begin{tabular}{|l|l|l|l|l|}
\hline Município & Localização & pH & OD & Temperatura \\
\hline Salesópolis & Barragem de Ponte Nova - distrito Nossa Senhora dos Remédios & 6,34 & 6,0 & $18,8^{\circ}$ \\
\hline Biritiba Mirim & Estrada do Rio Acima & 6,57 & 5,87 & $18,3^{\circ}$ \\
\hline Mogi das Cruzes & Estrada Joaquim Pereira de Carvalho - loteamento Volta Fria & 6,0 & 2,27 & $19,1^{\circ}$ \\
\hline Suzano & Ponte da Av. Miguel Badra - loteamento Miguel Badra & $\mathbf{7 , 0}$ & $\mathbf{0 , 8 0}$ & $\mathbf{1 9 , 0 ^ { \circ }}$ \\
\hline Itaquaquecetuba & Estrada do Bom Sucesso - loteamento Vila Japão & 6,8 & 0 & $23,0^{\circ}$ \\
\hline Guarulhos & Estrada da Olaria - loteamento dos Pimentas & 6,0 & 0 & $22,0^{\circ}$ \\
\hline
\end{tabular}

Tabela desenvolvida por Michele de Sá Vieira, a partir de dados levantados pela Sabesp e Agência Ambiental de Mogi das Cruzes

Fonte: Agência Ambiental de Mogi das Cruzes, 2009

Assim, os critérios levantados demonstram que embora o $\mathrm{pH}$ esteja dentro dos parâmetros aceitáveis em todos os municípios, o OD encontra-se bastante alterado em toda a bacia, à exceção de Salesópolis, o que significa que a qualidade da água do Rio Tietê já se encontra degradada a partir de Biritiba Mirim. Ou seja, quando o rio chega em Suzano já está comprometido. 

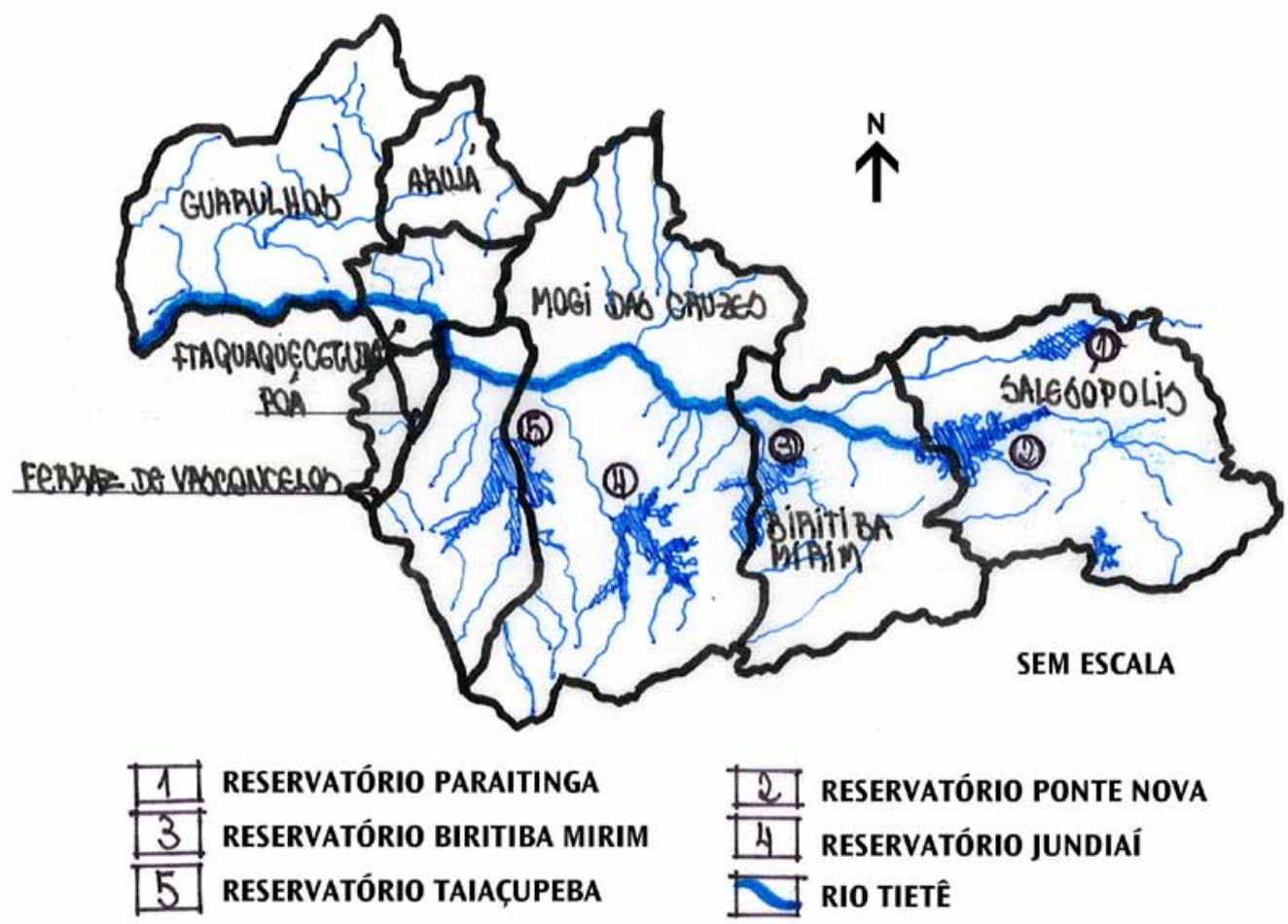

Mapa que aponta os municípios envolvidos na coleta da água para o levantamento de dados que evidenciam a qualidade da água na Bacia do Alto Tietê Cabeceiras

Fonte: Desenho criado por Michele de Sá Vieira, baseado em mapa que mostra as Áreas de Interesse Ambiental Especial da Secretaria Estadual de Meio Ambiente, 2000 


\section{Sistema de espaços livres públicos: A constituição de cenários futuros}

\section{Cenários possíveis: Conexões internas}

Com os cruzamentos das informações observadas nos mapas verifica-se que, embora as ocupações urbanas, a agricultura e até mesmo as matas de eucaliptos se constituam como barreiras na interligação dos fragmentos, existindo possibilidades para que as conexões aconteçam tanto no sentido latitudinal, quanto longitudinal do território.

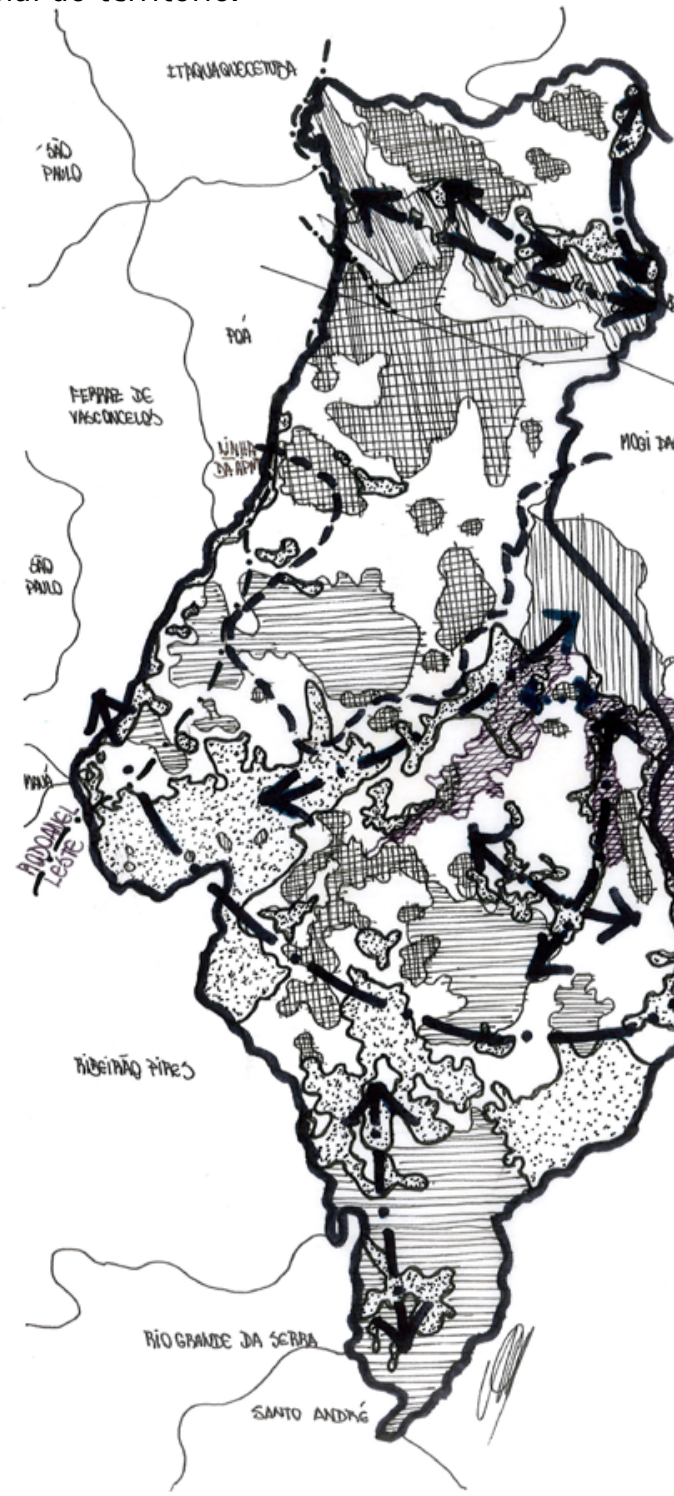

Mapa que demonstra as possíveis conexões dentro do município de Suzano

Fonte: Desenho criado por Michele de Sá Vieira, 2011 - baseado em mapa (T-3, cobertura vegetal e uso do solo) da Prefeitura Municipal de Suzano - PMS, 2008 
Observa-se, no entanto, que a futura instalação do Rodoanel Leste, bem como a ampliação da Represa de Taiaçupeba, irão restringir ou impossibilitar algumas conexões que ainda seriam possíveis, caso estas ações não acontecessem.

No entanto, apesar do papel da vegetação nativa ser fundamental na qualidade dos espaços livres públicos locais, outros elementos são essenciais dentro do sistema, em especial com relação à recreação, tais como:

- as amplas várzeas nas três bacias, que se poderão se integrar ao sistema a partir da implantação de parques lineares e corredores ecológicos nestas áreas;

- as praças existentes na região central e nos bairros;

- os espaços que ainda estão livres, ou seja, sem uso algum;

- os parques municipais, como o Max Feffer e o Mirante do Tietê;

- - os locais de interesse ambiental e paisagístico, como os situados ao longo dos córregos, caracterizados como Área de Proteção Permanente - APP.

No que se refere às praças e parques entende-se que, embora a região central seja uma barreira na interligação norte-sul dos fragmentos, sem dúvida estes poderão funcionar como stepping stones, ou seja, como pontos de parada e descanso nos deslocamentos da avifauna, contribuindo, dessa forma, para com as interligações ainda que de maneira restrita. 


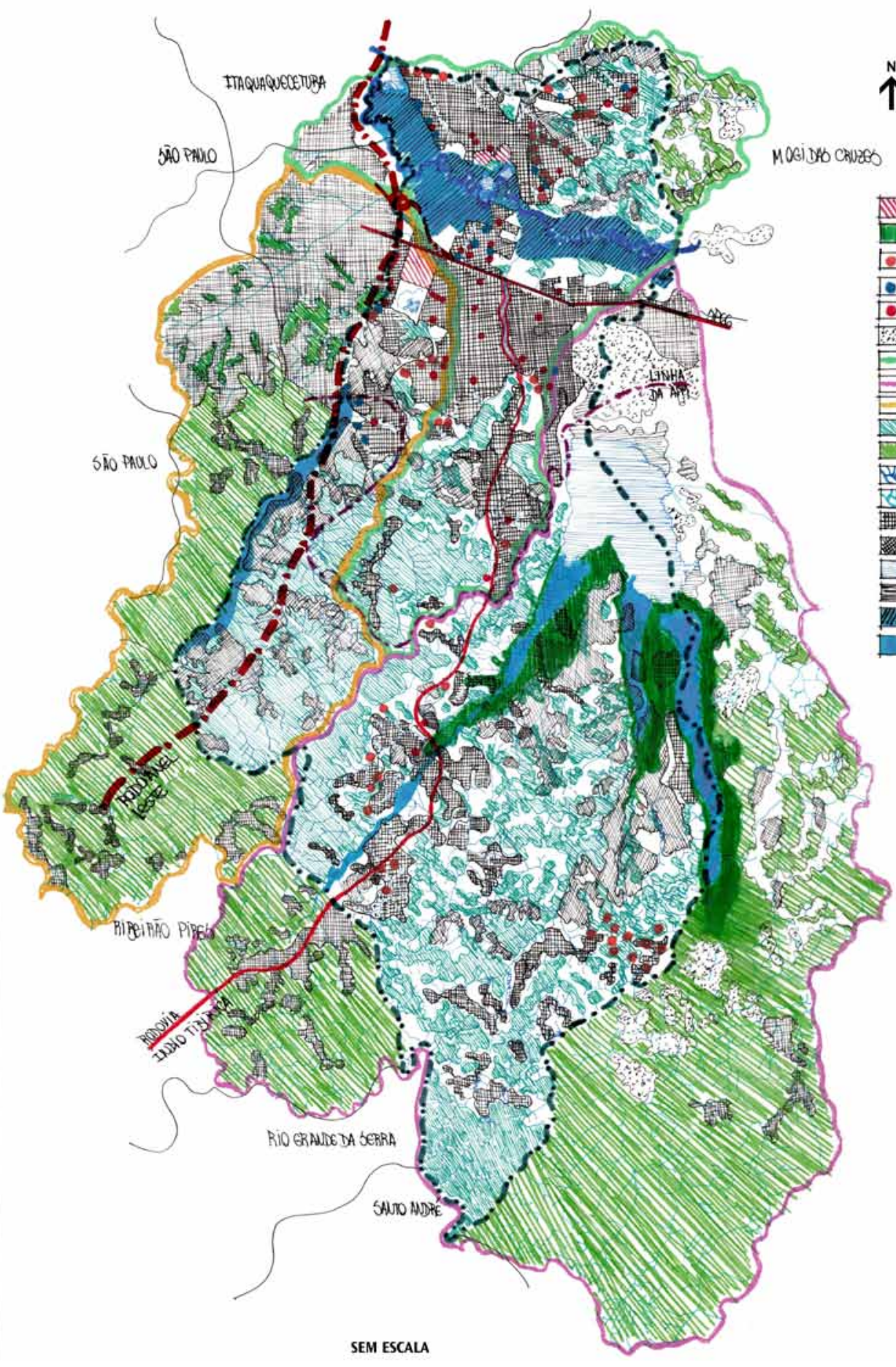

PARQUES MUNICIPAIS

AMPLIAC̄̃̃ DA REPRESA DE TAIAÇUPEBA

- ÁREA dE INTERESSE AMBIENTAL E PAISAGÍstico

CAMPO DE FUTEBOL

PRAÇAS

EXTRAÇ̃̃o MINERAL

BACIA DO TIETÉ-LESTE

BACIA DO TAIAÇUPEBA

BACIA dO GUAIÓ

VEGETAÇ̃̃O DE MATA - SUZANO

VEGETAC̄̃̃O DE MATA - EXTRA SUZANO

SISTEMA HIDRICO - SUZANO

SISTEMA HÍDRICO - EXTRA SUZANO

ÁREA URBANIZADA

PROduÇ̃o AGRÍCOLA

REPRESA DE TAIAÇUPEBA

ÁREAS ALAGADAS

VÁRZEA dO TIETÊ

VÁRZEAS LEVANTADAS VIA SENSORIAMENTO REMOTO

Mapa que apresenta as diversas potencialidades ambientais $e$ paisagísticas, tanto internas quanto externas ao território, a serem utilizadas para a composição do sistema de espaços livres públicos

Fonte: Desenho criado por Michele de Sá Vieira, 2011 baseado em mapa T -13 (locação de várzeas e levantadas via sensoriamento remoto) da Prefeitura Municipal de Suzano - PMS, 2008 e mapa de Uso e Ocupação do Solo da Empresa Paulista de Planejamento Metropolitano - EMPLASA, 2006 


\section{Cenários possíveis: Conexões externas}

Para além das conexões internas, entende-se que a vegetação nativa de Suzano não está isolada. Ela se encontra conectada com importantes fragmentos situados nos territórios vizinhos, podendo ser ampliadas da seguinte maneira:

- ao norte, com os municípios de Itaquaquecetuba e Mogi das Cruzes;

- ao centro com Poá;

- principalmente, na parte sul, com os municípios de Ferraz de Vasconcelos, Mauá, Ribeirão Pires, Rio Grande da Serra, Santo André e Mogi das Cruzes. 


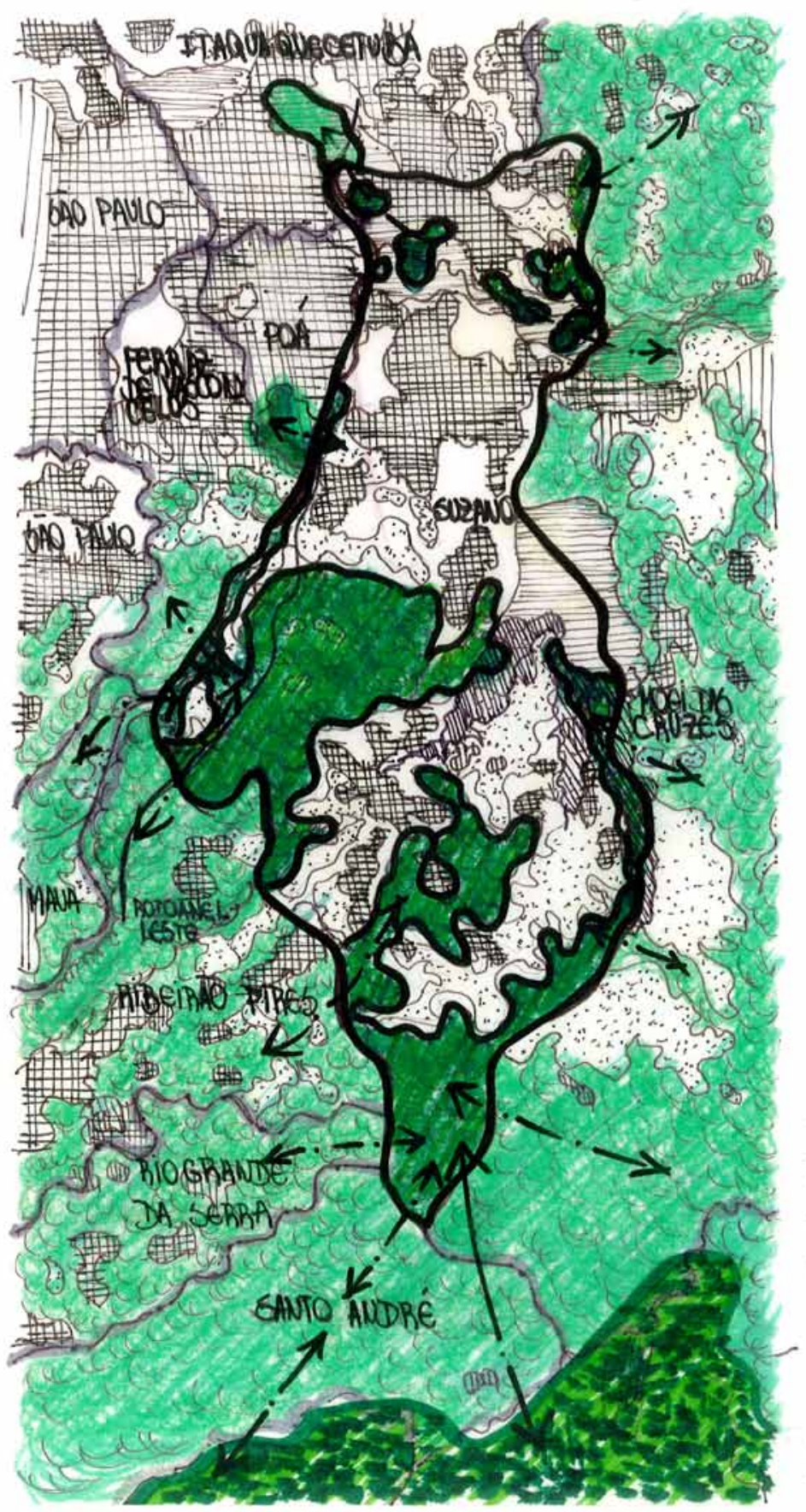

Mapa que aponta as conexões que podem ser estabelecidas com os municípios vizinhos

Fonte: Desenho criado por Michele de Sá Vieira, 2011 - baseado em mapa de Uso e Ocupação do Solo da EMPLASA - Empresa Paulista de Planejamento Metropolitano, 2005. $\uparrow_{\text {Sem escala }}^{N}$

SERRA dO MAR
VEgETACC̃̃o SUZANO
VEGETAÇÃO EXTRA
SUZANO

AGRICULTURA

OCUPAÇÕES

ÁGUAS

POSSÍVEIS CONEXÕES

NUY AMPLIAÇÃO DA REPRESA

Af DE TAIAÇUPEBA 


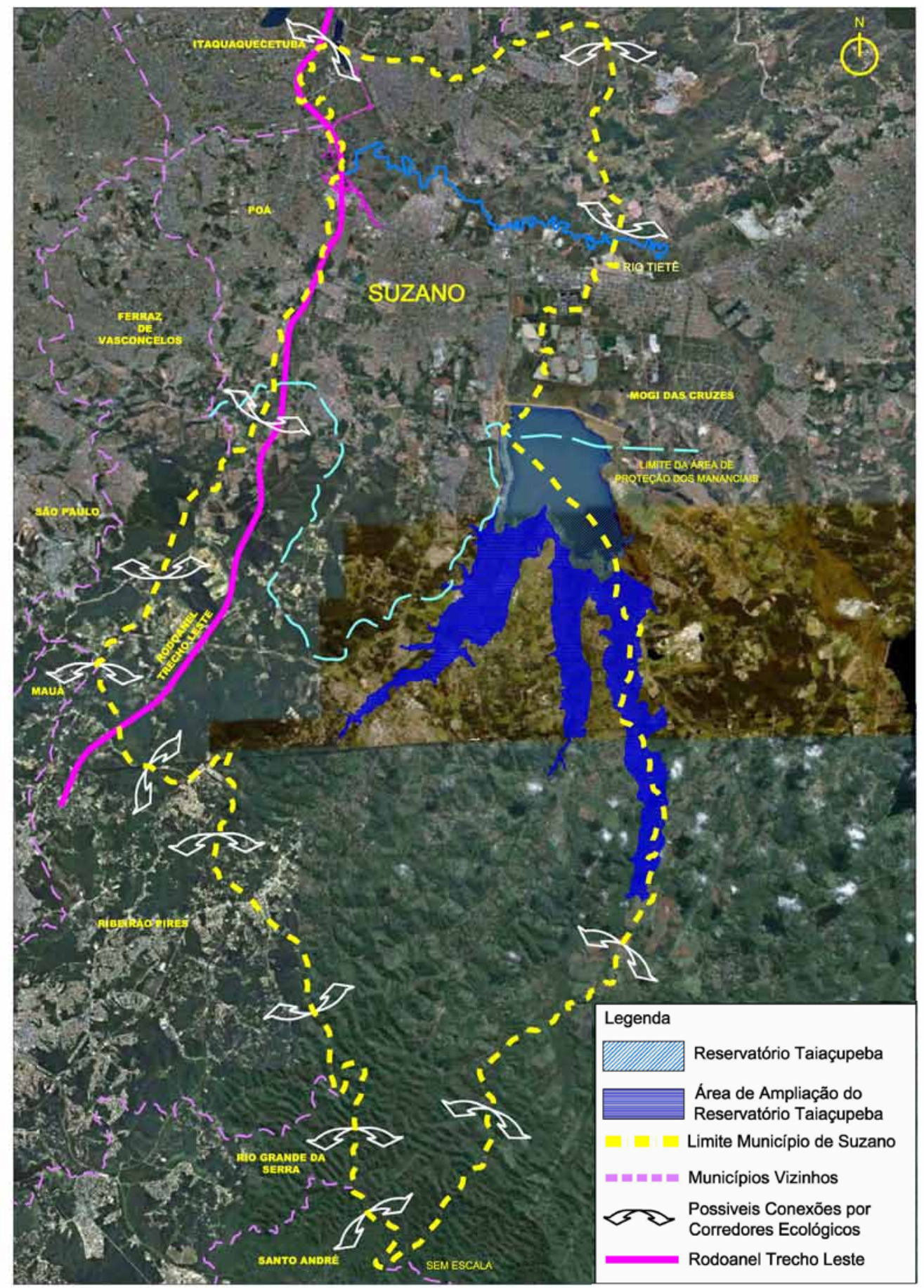

Mapa criado por Michele de Sá Vieira e Sanderlei Fernandes Vilanova, a partir de imagens do Google, acessado em dezembro de 2011, objetivando demonstrar a capacidade que o território de Suzano possui em promover conexões com os fragmentos florestais dos municípios vizinhos 


\section{Cenários possíveis: Conexões entre matrizes}

Após perpassar pelos vários princípios da ecologia de paisagens, especialmente por aqueles diretamente usados no planejamento do uso do solo e na arquitetura paisagística, tais como matrizes, manchas, corredores, stepping stones e bordas, compreendendo como estes podem se articular; e somando-se à apropriação do território de Suzano, sob o viés dos conflitos e das potencialidades, propõe-se um "esquema", o qual demonstra o potencial que o município possui em funcionar como um extenso e rico corredor, capaz de conectar a Serra do Itapety à Serra do Mar, em função da existência da vegetação entre estes espaços.

Dessa forma, observa-se que as áreas protegidas de Suzano, tal como a APA e a APM, entre outras, atuam como manchas, que podem vir a contribuir para uma possivel conexão entre as matrizes, Serra do Itapety e Serra do Mar, mas para que isso aconteça verifica-se que a malha urbana, presente no distrito central, é uma barreira a ser superada, por conter pouquíssimos recursos ambientais, tais como águas e matas nativas preservadas, capazes de contribuir para a conectividade.

Para que a área onde se situa a malha urbana possa colaborar com a conexão, as estratégias a serem utilizadas estão vinculadas à ampliação e implementação de praças, parques lineares e não lineares; recuperação dos corpos d'água, através do saneamento ambiental e tratamento paisagístico; ampliação dos fragmentos florestais onde estes ainda existem; inserção de arborização nas calçadas e nos canteiros centrais, bem como nos espaços remanescentes dos corpos d'água, entre outros. A execução destas ações funcionaria como stepping stones, ou seja, como pontos de apoio, para a interligação entre os grandes fragmentos de mata. 
Esta conexão, que possui como objetivo principal interligar as matrizes, não estaria vinculada somente aos princípios ecológicos, ou seja, a ideia de que todas as espécies, todos os fluxos de energia e alimento, que acontecem na Serra do Itapety, teriam que transpor a malha urbana para chegar à Serra do Mar e vice-versa, mas, sobretudo, esta "linha" de conectividade seria utilizada para a implementação de ações que buscassem a valorização do território, a partir de princípios ambientais e paisagísticos.

Ambientais, dado aos benefícios climáticos, a qualidade do ar e da água, que se teria ao executar as estratégias comentadas, as quais contribuiriam para a qualidade de vida das pessoas, que iriam usufruir do seu cotidiano junto aos espaços livres, através das suas relações de trabalho, da vida em família e do lazer com os amigos.

Paisagísticos, pois no momento em que se implantam fragmentos de mata, praças, parques, vegetação nas calçadas, entre outros, isto acabaria por ampliar o embelezamento da paisagem urbana, bem como a qualificação do sistema de espaços livres locais. 


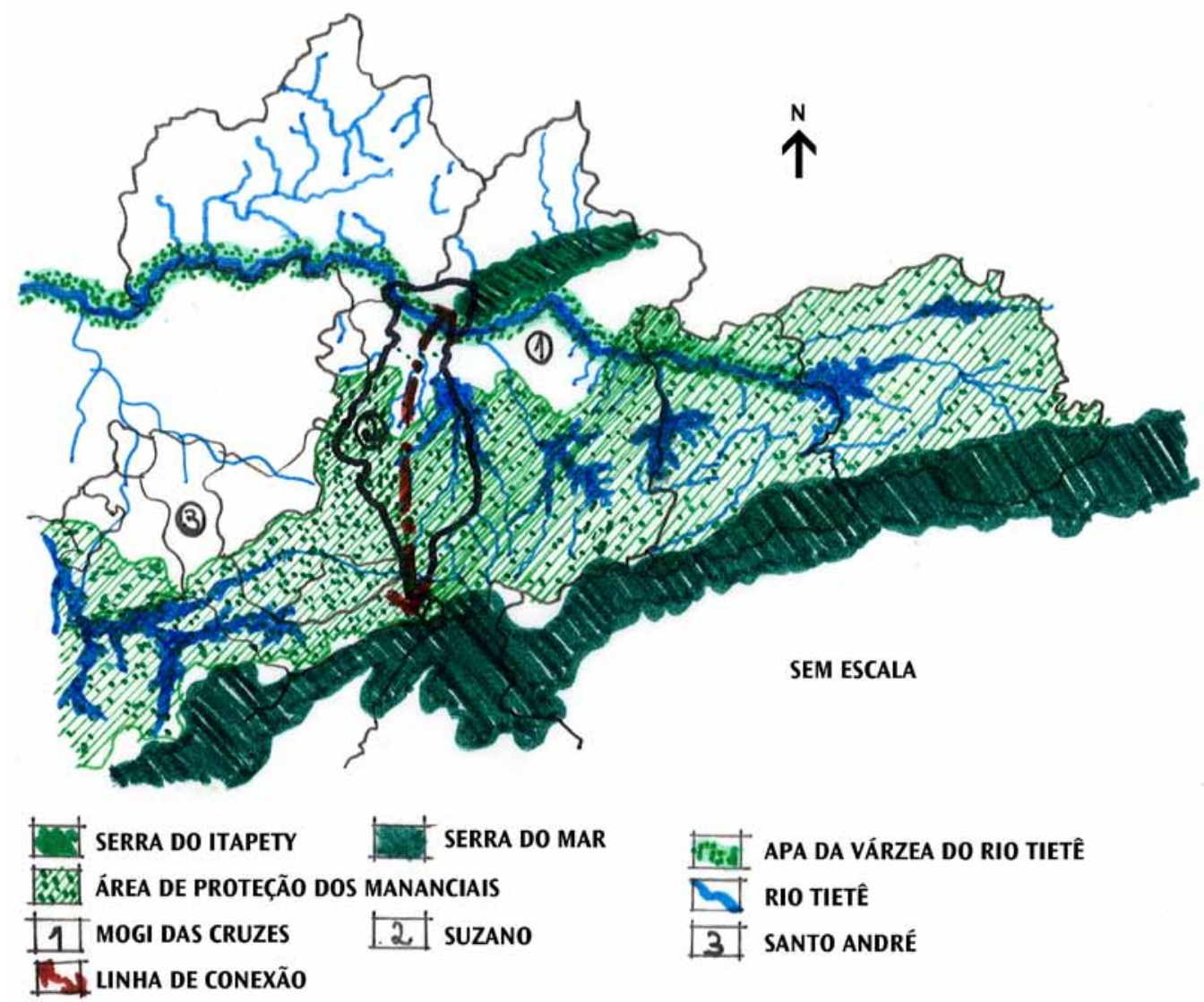

Mapa que localiza toda a Serra do Itapety e parte da Serra do Mar, demonstrando a possível conexão a ser estabelecida entre estas matrizes, dentro do território de Suzano Fonte: Desenho criado por Michele de Sá Vieira, 2012 - baseado em mapa que demonstra as Áreas de Interesse Ambiental Especial da Secretaria Estadual de Meio Ambiente, 2000 
Mapa que detalha a possível conexão a ser estabelecida entre a Serra do Itapety e a Serra do Mar, utilizando-se das manchas de vegetação existentes nos municípios de Suzano e Santo André Fonte: Desenho criado por Michele de Sá Vieira, 2012 - baseado em mapa que demonstra as Áreas de Interesse Ambiental Especial da Secretaria Estadual de Meio Ambiente, $2000 \mathrm{e}$ mapa do Uso e Ocupação do Solo da Empresa de Planejamento Metropolitano - Emplasa, 2006

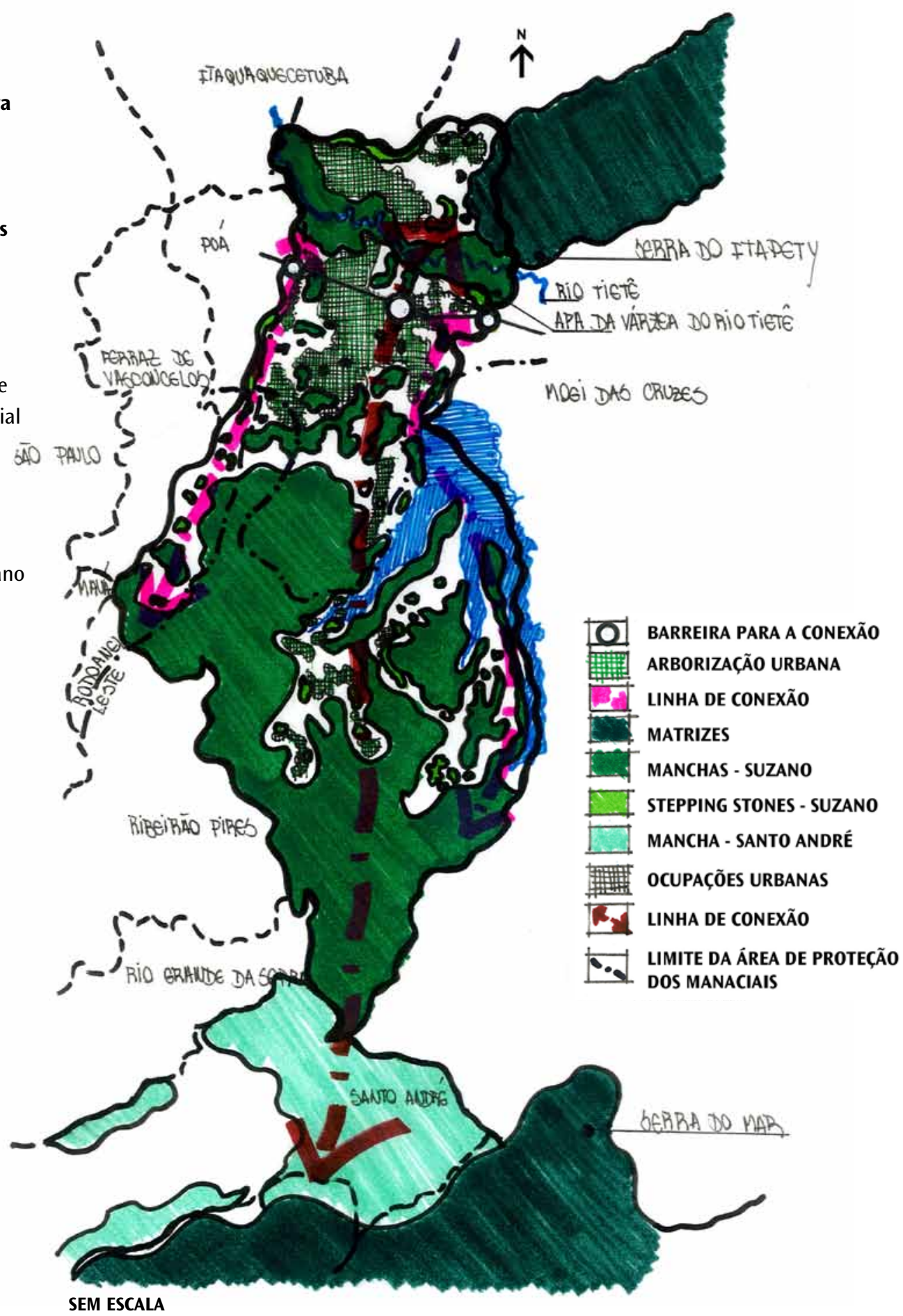




\section{Sistema de espaços livres públicos: Uma proposta para o território de Suzano}

\section{Proposta do sistema: Um esquema para Suzano}

A intenção é ilustrar, de forma esquemática, uma proposta para a constituição do sistema de espaços livres públicos planejado para o município de Suzano.

Em 2012, o território possui um sistema de espaços livres públicos convencional, pautado apenas em interligações voltadas ao transporte, ao controle dos recursos hídricos por meio de canalizações, ao percurso elementar dos pedestres, ou seja, em situações-padrão. No entanto, este sistema pode evoluir para alcançar uma forma não convencional, planejada, capaz de resgatar as funções ecológicas, através da implantação de um modelo morfológico, elaborado em conformidade com as estruturas ecológicas, ambientais e paisagisticas de cada lugar deste município.

Suzano possui sua paisagem totalmente fragmentada, proveniente de uma urbanização acelerada, além de intensa escassez de espaços livres públicos tratados, ou seja, que possuam arborização, acessibilidade, mobiliário urbano, bem como equipamentos de lazer e recreação. Esta proposta, portanto, procura demonstrar que a implementação, ou a requalificação do sistema, beneficiará 0 município, tanto na valorização de suas áreas de convivio, quanto no aumento da biodiversidade deste território.

Dessa forma, entende-se que a criação de um sistema de espaços livres públicos, o qual possuirá como principal estratégia a possivel interligação entre a Serra do Itapety e a Serra do Mar, utilizando-se dos parques lineares e dos corredores ecológicos como 
elementos fundamentais para que esta conexão aconteça, trata-se do elemento central desta proposta.

Neste âmbito, os corredores ecológicos se destacam como um tema sempre trabalhado no paisagismo, em especial na vertente vinculada à ecologia de paisagens, que se reflete na recomposição de matas ciliares, prevendo, assim, a reestruturação das margens de córregos e rios, cumprindo suas funções ecológicas, tendo como objetivo promover interligações.

Por outro lado, os parques lineares cumprirão um exercício prático, permitindo que a população desfrute de espaços voltados ao lazer, esporte e convivência, exercendo também um papel importante na conectividade dos espaços quando sua vegetação for trabalhada para atender a esta finalidade. Assim, estes parques serão uma oportuna medida que poderá levar o território: ao resgate da paisagem local, beneficiando os loteamentos do entorno, a valorização das áreas de convívio e o aumento sua biodiversidade. Além disso, potencializarão a permeabilidade do solo nas regiões onde vão ser implementados, contribuindo para a recomposição da mata ciliar, conservação dos solos, controle de processos erosivos e de assoreamento, e melhoria nos níveis de quantidade e qualidade dos recursos hídricos, como um todo.

Além dos os aspectos citados anteriormente, os parques lineares possuirão outras funções como:

- a manutenção das áreas de várzeas remanescentes, pois quando o uso for destinado a parques, estas áreas deixarão de ser ocupadas irregularmente por habitações, resguardando, dessa maneira, suas reais funções, ou seja, atuarão como um espaço que possa abrigar as cheias nas épocas de chuva; 
- a devolução das áreas degradadas, caso recuperadas, às suas funções originais de amortecimento de vazões, que se darão também na época das chuvas, mas, para que isto aconteça, por muitas vezes, será preciso que se retire as famílias destas áreas, propondo-se, posteriormente, a restauração ambiental destes espaços através da implantação destes parques.

Como aplicação prática entende-se que os corredores ecológicos e os parques lineares vão poder ser implantados em diversos locais de Suzano, sendo que, em alguns espaços, será fundamental sua implantação como: ao longo dos rios Jaguari, Tietê, Guaió, Una e Taiaçupeba, por poderem colaborar com o resgate ecossistêmico e ambiental, além da requalificação urbana. Considera-se, ainda, que a proposta da criação do sistema de corredores ultrapasse os limites do território em análise, pois, como já foi colocado, existem inúmeras opções de interligações com os municipios vizinhos.

Entende-se que outras ações, além das que foram colocadas, também são fundamentais para a constituição do sistema de espaços livres, tais como: a universalização dos serviços vinculados à água e ao esgoto, a ampliação do número de praças e parques, a construção e requalificação de calçadas com a implementação de espécies arbóreas, bem como o tratamento paisagístico de áreas remanescentes aos corpos d'água.

Para além das obras ligadas à infraestrutura, outras ações devem ser consideradas como a aprovação das Leis Específicas, pela Assembléia Legislativa, pois isto possibilitará a regularização de diversos loteamentos irregulares existentes na APM de Suzano. Esta regularização, por sua vez, irá permitir que obras estruturais como o abastecimento de água, bem como o esgotamento sanitário, parques lineares e não lineares, além das praças, sejam levados 
para estas áreas, colaborando dessa forma, para a ampliação do sistema.

Assim, após analisarmos todas as possibilidades no que se refere às possiveis conexões, tanto com relação às que podem acontecer dentro do território, quanto as que podem se dar com os municípios vizinhos, além de outras possíveis ações, como as que acabaram de ser comentadas, propõe-se aqui um esquema-síntese, o qual está acompanhado por uma tabela-síntese que sugere a prioridade de espaços para investimentos públicos, bem como de ações para a construção de um cenário voltado à constituição de um sistema de espaços livres públicos. 


\section{Esquema-síntese}

ARBORIZAÇ̃̃o URBANA - IMPLEMENTAÇōES

. CONEXÃo entre a SERra do ITAPETY E A SERRA do MAR (MATRIZES)

- CONEXÃO DOS FRAGMENTOS DE MATA EXISTENTES NA APA DO RIO TIETÊ (MANCHAS)

- CORREDOR ECOLÓGICO - AO LONGO DA RODOVIA ÍNDIO TIBIRIÇÁ E dEMAIS SISTEMAS VIÁRIOS

T. CORREDORES ECOLÓGICOS E/OU PARQUES LINEARES PRÓXIMOS A REPRESA DE TAIAÇUPEBA E DO RIO GUAIÓ

CONEXÃO HORIZONTAL DOS FRAGMENTOS DE MATA NA APM

SII CONEXÕES COM OS MUNICÍPIOS VIZINHOS

MATRIZES

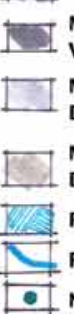

MANCHAS - MUNICÍPIOS

VIZINHOS

MANCHAS - MUNICÍPIO

DE SUZANO

MANCHAS - APA DA VÁRZEA

DO RIO TIETÊ

REPRESA DE TAIAÇUPEBA

RIO GUAIÓ

NOVAS PRACAS E PARQUES

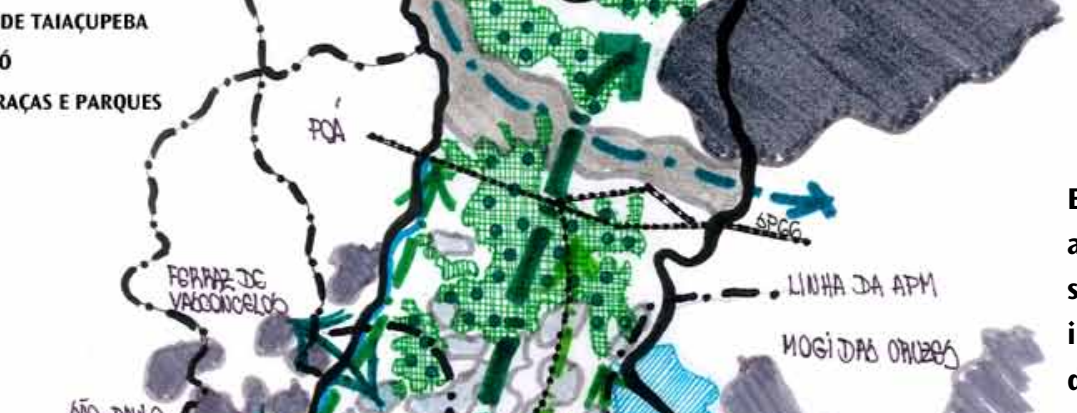

Esquema demonstrando

as possíveis conexões a

serem estabelecidas para a

implantação de um sistema

de espaços livres públicos em

Suzano

Fonte: Desenho criado por

Michele de Sá Vieira, 2012

- baseado em mapa T -13

(locação de várzeas, levantadas

via sensoriamento remoto) -

Plano de Macrodrenagem) da

Prefeitura Municipal de Suzano

- PMS, 2008 e mapa de Uso e

Ocupação do Solo da Empresa

Paulista de Planejamento

Metropolitano - EMPLASA, 2006

SERRA DO MAR

SEM ESCALA 


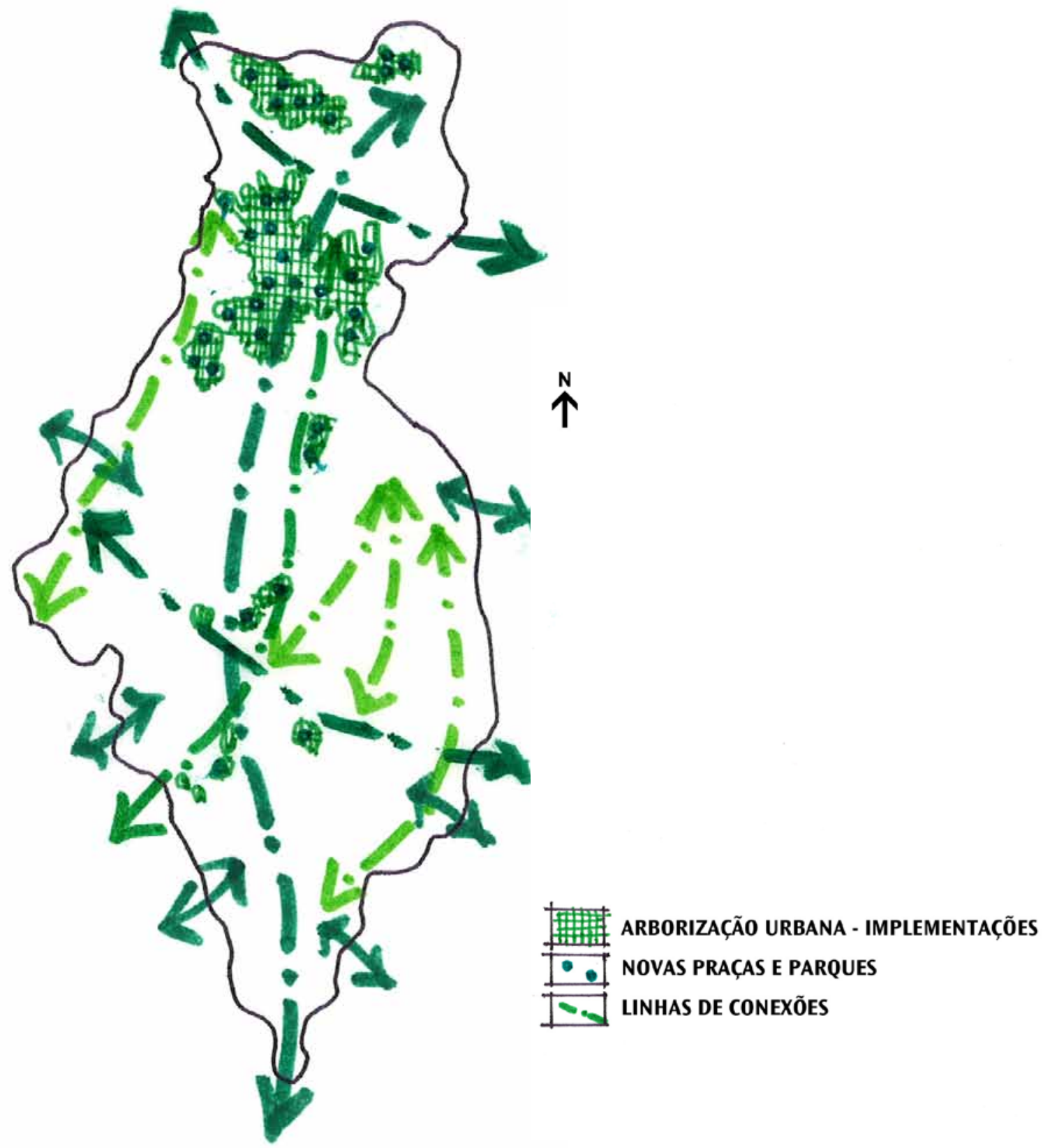

Síntese da proposta, com a indicação das interligações, bem como de alguns elementos essenciais para a constituição do sistema de espaços livres públicos de Suzano

Fonte: Desenho criado por Michele de Sá Vieira, 2012 - baseado em esquema demonstrando as possíveis conexões a serem estabelecidas para a implantação de um sistema de espaços livres públicos em Suzano, 2012 


\section{Tabela-síntese}

\begin{tabular}{|c|c|}
\hline $\begin{array}{l}\text { Prioridade de espaços para investimentos públicos na } \\
\text { constituição de um sistema de espaços livres públicos }\end{array}$ & $\begin{array}{l}\text { Ações para a construção de um cenário ideal voltado } \\
\text { à constituição do sistema de espaços livres públicos }\end{array}$ \\
\hline Áreas urbanizadas do setor norte do território & Implementação de praças e requalificação das calçadas \\
\hline Área de Preservação Permanente do Córrego Jaguari & Desenvolvimento de parques lineares \\
\hline Área ao norte próxima a divisa de Mogi das Cruzes & $\begin{array}{l}\text { Implementação de fragmentos de mata nativa para uma } \\
\text { possível conexão com a Serra do Itapety }\end{array}$ \\
\hline Área do Parque Mirante do Tietê & Implementação efetiva do parque \\
\hline Área de Proteção Ambiental da várzea do rio Tietê & $\begin{array}{l}\text { Implementação do Parque Várzeas do Tietê, com espaços } \\
\text { de lazer, bem como de vegetação capaz de conectar os } \\
\text { fragmentos existentes }\end{array}$ \\
\hline Área urbanizada no setor central & $\begin{array}{l}\text { Implementação e requalificação de praças e parques } \\
\text { para que estes possam funcionar como "pontos de } \\
\text { apoio" dentro do sistema de espaços livres públicos }\end{array}$ \\
\hline Calçadas do setor central & $\begin{array}{l}\text { Criação de infraestrutura verde e implementação de } \\
\text { arborização }\end{array}$ \\
\hline $\begin{array}{l}\text { Espaço remanescente ao longo do Córrego Chico da } \\
\text { Vargem (Rio Una) }\end{array}$ & Tratamento paisagístico \\
\hline $\begin{array}{l}\text { Áreas desocupadas e próximas do Córrego Chico da } \\
\text { Vargem (Rio Una) }\end{array}$ & $\begin{array}{l}\text { Implementação de parques e praças que possam se } \\
\text { conectar ao espaço remanescente do Córrego Chico da } \\
\text { Vargem (Rio Una) }\end{array}$ \\
\hline Parque Max Feffer & Tratamento paisagístico \\
\hline Espaço ao longo da Represa de Taiaçupeba & $\begin{array}{l}\text { Criação de parques lineares, onde a população próxima } \\
\text { possa desfrutar do equipamento e de corredores ecológi- } \\
\text { cos nas áreas não habitadas }\end{array}$ \\
\hline Área remanescente ao longo do Rio Guaió & $\begin{array}{l}\text { Implantação de corredores ecológicos por meio de reflo- } \\
\text { restamentos }\end{array}$ \\
\hline Área de Proteção dos Mananciais & $\begin{array}{l}\text { Criação de corredores ecológicos e parques lineares, } \\
\text { interconectando os vários fragmentos de mata que ali } \\
\text { existem }\end{array}$ \\
\hline $\begin{array}{l}\text { Municípios que fazem fronteira com o território de } \\
\text { Suzano }\end{array}$ & $\begin{array}{l}\text { Potencialização de corredores ecológicos para a conexão } \\
\text { com os municípios de Itaquaquecetuba, Poá, Ferraz de } \\
\text { Vasconcelos, Mauá, Ribeirão Pires, Rio Grande da Serra, } \\
\text { Santo André e Mogi das Cruzes }\end{array}$ \\
\hline $\begin{array}{l}\text { Áreas situadas na linha de conectividade entre a Serra do } \\
\text { Itapety e a Serra do mar }\end{array}$ & $\begin{array}{l}\text { Implementação dos diversos tipos de elementos da pai- } \\
\text { sagem, tais como, parques praças, corredores ecológicos } \\
\text { e etc., para que as serras possam ser conectadas dentro } \\
\text { dos aspectos ambientais e paisagísticos }\end{array}$ \\
\hline Território de Suzano & $\begin{array}{l}\text { Universalização dos serviços voltados ao abastecimento } \\
\text { de água e ao esgotamento sanitário }\end{array}$ \\
\hline Região do Alto Tietê Cabeceiras & Aprovação das Leis Específicas \\
\hline
\end{tabular}

Fonte: Tabela criada por Michele de Sá Vieira, a partir da proposta desenvolvida no esquema síntese, 2012 
ENTRE AS SERRAS: SISTEMA DE ESPAÇOS LIVRES PÚBLICOS, UMA REFLEXÃO PARA SUZANO 


\section{A gestão pública e os entraves para o alcance dos objetivos}
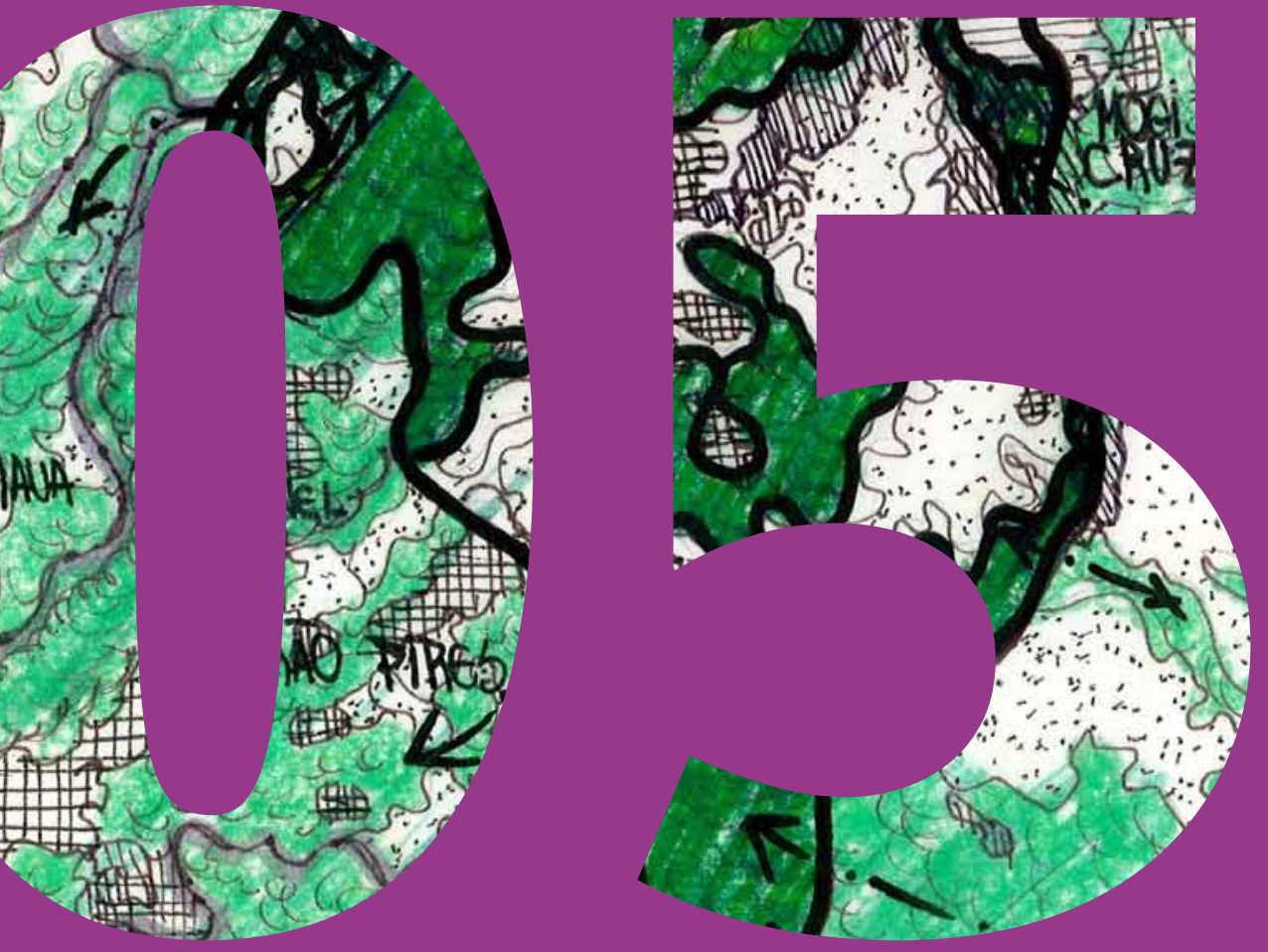



\section{A gestão pública e os entraves para 0 alcance dos objetivos}

$\mathrm{Na}$ administração do território municipal, o Estado é responsável por uma parcela significativa dessa gestão. Como qualquer processo no interior de cada instância governamental, as deficiências, assim como os sucessos, são constantes.

A crônica descontinuidade administrativa, em termos de ações políticas, associada a uma não priorização na administração das políticas voltadas à paisagem e ao ambiente, prejudicam imensamente a concretização de um sistema de espaços livres públicos. Somada a este aspecto, a ausência de cuidados por parte da administração pública em relação às questões urbanas, paisagísticas e ambientais, é um fato comum, podendo ser atribuida a diversos motivos, tais como a inexistência de políticas focadas no sucesso, falta de recursos, deficiência crônica com relação aos quadros técnicos administrativos, bem como a outras questões que seguem descritas no texto, fundamentais para o entendimento da situação.

\section{Composição dos cargos}

Os fatores políticos são fundamentais no entendimento dos processos de gestão e conformação do território e, com certeza, a composição e o preenchimento dos cargos administrativos de confiança, ou não, influenciam de um modo estrutural os diversos resultados da gestão.

Objetivando atender demandas exclusivamente políticas, os dirigentes possuem o hábito de indicar para o preenchimento de muitos de seus cargos, seja para as Coordenadorias, Diretorias, 
IObserva-se que a prática de indicação é recorrente no Brasil, nas inúmeras instituições públicas, sejam elas municipais, estaduais ou federais. Este hábito se aplica aos governos municipais, a exemplo de várias Prefeituras que compõem a Bacia Hidrográfica do Alto Tietê Cabeceiras, as quais possuem os cargos de primeiro escalão vinculados à agenda ambiental, em sua grande maioria, ocupados por indicações partidárias sem vínculo expressivo com o assunto, bem como Câmaras Municipais, que atendem interesses específicos, necessariamente não vinculados com tal questão. A mesma situação é recorrente na composição do secretariado no governo do Estado de São Paulo, considerando-se que o atual secretário de Meio Ambiente (2012) não possui formação técnica na área de conhecimento voltada à esfera ambiental.
Secretarias e Ministérios, pessoas que não possuem conhecimento suficiente sobre temáticas especificas e muito menos noções básicas das questões ambientais e paisagísticas, o que indica, portanto, que os governos, na verdade, desenvolvem uma composição técnica e política dentro da administração pública!.

Sem dúvida, o correto encaminhamento político, que significa, por exemplo, contratar ou indicar pessoas com conhecimento técnico, é essencial para que as políticas públicas ambientais, como o licenciamento e a fiscalização, o saneamento ambiental, a educação ambiental, a conservação dos recursos naturais, a implementação de um sistema de espaços livres públicos, possam realmente ser executadas. No entanto, quando uma gestão conta com muitos de seus componentes completamente desprovidos de capacidade técnica especifica, conhecimento científico e habilidade de interlocução, isto certamente gera comprometimentos negativos.

\section{Instabilidade das equipes}

Para além da distribuição direcionada dos cargos conta-se, também, com a instabilidade das equipes técnicas contratadas para o desenvolvimento de planos, projetos e ações, pois ao término dos contratos, por vezes, os trabalhos são definitivamente ou momentaneamente paralisados em decorrência da falta de profissionais ou recursos para sua implementação desestruturando, dessa maneira, o desenvolvimento das atividades junto aos órgãos administrativos.

Mediante a isso, o Poder Público busca outras formas de contratação para vencer os entraves como, por exemplo, a contratação 
das empresas visando a terceirização de serviços e mão-de-obra, ganhando dessa forma maior mobilidade na execução de planos e projetos. Em função destes fatos, incorpora-se a construção de uma cultura de trabalhos técnicos vinculados à gestão pública, por intermédio de empresas terceirizadas, através de estratégias que buscam resolver os processos burocráticos.

Isso se dá nas mais diversas áreas como o meio ambiente, 0 transporte, a saúde, a educação, a habitação, entre outros, objetivando, dessa maneira, a execução de planos e projetos para que assim a implementação das políticas públicas possam se consolidar.

\section{Escassez de recursos}

Outros entraves ainda impedem a fluidez de uma agenda ambiental. Trata-se dos escassos recursos destinados ao meio ambiente, para o encaminhamento das demandas, considerando-se que a estrutura administrativa pública, assim como a privada, não se mostram ágeis.

Nesse sentido, alguns fatos são considerados para que aconteça a distribuição dos recursos anuais junto aos órgãos administrativos que compõem um governo, tais como:

- a sintonia entre projetos e obras que entram na proposta orçamentária de um ano para o outro, visando a continuidade das ações de uma administração, trabalhando-se dessa forma por um viés mais conservador;

- a não transferência de responsabilidades orçamentárias administrativas para um próximo governo; 
- a manutenção de ações previamente anunciadas, com o intuito de se evitar perdas estruturais e políticas;

- $\quad$ enfrentamento dos grandes temas prioritários que estão em andamento dentro de um governo, muitas vezes ligados ao transporte, à saúde e à educação;

- a garantia de obras definidas no orçamento participativo, acordadas com a população ou com segmentos influentes da sociedade;

- $\quad$ projetos e programas que possuam interligação com obras e ações vinculadas aos governos estadual e federal;

- a alta capacidade que determinadas ações possuem com relação à obtenção de votos, entre outros.

Diante deste contexto, por inúmeras vezes as agendas ambientais, voltadas às mudanças climáticas, educação ambiental, resíduos sólidos, restauração ambiental, fiscalização, monitoramento dos recursos naturais e sistema de espaços livres, não são contempladas com recursos suficientes para a sua implantação.

Assim, os órgãos ambientais são obrigados a utilizar caminhos alternativos para alcançar alguns de seus objetivos, que por muitas vezes se dão através de parcerias estabelecidas com o setor privado, seja com as indústrias ou com o comércio, para conseguir cumprir agendas que são fundamentais ao desenvolvimento da política nacional, estadual e municipal de meio ambiente, mas que por vezes não contam com apoio pleno da administração pública. 


\section{Entraves burocráticos: licitações públicas}

Com relação aos empecilhos constantes na administração pública comenta-se os resultados advindos da Lei n. 8.666, de 12 de junho de 1993, a qual regulamenta o Art. 37, inciso XXI, da Constituição Federal, onde institui-se normas para licitações e contratos da Administração Pública e dá outras providências.

Nesta, alguns elementos são fundamentais para a compreensão quanto aos entraves burocráticos recorrentes, a exemplo do Art. 10, que estabelece normas gerais sobre licitações e contratos administrativos pertinentes a obras, serviços, inclusive de publicidade, compras, alienações e locações no âmbito dos Poderes da União, dos Estados, do Distrito Federal e dos Municípios.

No parágrafo único do Art. 10 coloca-se que é permitido à administração pública direta, bem como aos fundos especiais, às autarquias, às fundações públicas, às empresas públicas, às sociedades de economia mista e demais entidades controladas direta ou indiretamente pela União, Estados, Distrito Federal e Municípios, contratação de obras, serviços, inclusive de publicidade, compras, alienações, concessões, permissões e locações, quando precedidas de licitação.

No entanto, com relação às obras, o que se observa é que embora esta lei tenha os seus objetivos, como a transparência, a garantia do princípio da isonomia, seleção de propostas mais vantajosas, a garantia da promoção do desenvolvimento nacional sustentável, levando-se em consideração também os princípios básicos da legalidade, da impessoalidade, da moralidade, da igualdade, da publicidade, da probidade administrativa, permitindo assim processos licitatórios transparentes, por outro lado, por mui- 
tas vezes, o critério que trata das propostas mais vantajosas, ou seja, no que se refere aos custos, acaba gerando dificuldades para a implementação das obras, bem como dos serviços, não alcançando, dessa forma, os objetivos pretendidos.

Isto se deve, por exemplo, ao fato de que algumas empresas que vencem a concorrência, por apresentar uma proposta orçamentária com valores inferiores às demais, nem sempre estão preparadas realmente para assumir determinados empreendimentos, dado ao fato de possuírem equipes despreparadas, não ter capital inicial suficiente para investir na obra, não conseguir cumprir o cronograma de obras durante sua execução, não atender com qualidade aos aspectos da construção civil, bem como os prazos de entrega final das obras. Ou seja, na medida em que, ao final o critério, passa ser o menor valor apresentado pelas construtoras, perde-se a oportunidade de resguardar a qualidade do espaço edificado.

\section{A disputa entre os órgãos administrativos}

Prática constante, alguns órgãos, por muitas vezes, são fortalecidos pela administração com recursos expressivos e dotações orçamentárias para assumir determinadas demandas que não Ihes cabem especificamente, impondo-se de maneira agressiva e autoritária sobre outras que realmente possuem interface direta e capacidade técnica para gerenciar as atividades. 0 resultado desse fato acaba por gerar comprometimentos com relação ao desenvolvimento dos trabalhos, bem como das ações por falta de conhecimento e capacidade técnica. 
Na escala municipal esta prática acontece, sendo que a educação ambiental pode ser citada como uma das agendas e ações que entram na disputa entre as secretarias de Meio Ambiente e Educação, visando consolidar, em muitos momentos, interesses partidários específicos, considerando-se que, em determinados instantes, os secretários que ocupam os cargos fazem parte do Partido Verde.

Outra agenda em constante disputa é a do Saneamento Ambiental que, embora possua interface direta com o Meio Ambiente, por vezes é tomada por outras secretarias em função da sua importância estrutural e grande interface com questões relacionadas à habitação, no que se refere ao abastecimento de água e esgotamento sanitário, drenagem urbana, por se inter-relacionar com o órgão de Infraestrutura e Obras e Resíduos Sólidos, dada à relação com as secretarias voltadas aos Serviços Urbanos.

Dessa forma, por vezes, um trabalho não é atribuido ou até mesmo é retirado de um setor administrativo, sendo passado a outro que não possui interface com o tema a ser desenvolvido. 0 que se constata é que dentro da gestão pública, alguns órgãos são criados apenas como "fachada", ou melhor, para servirem como instrumentos de marketing de uma gestão, já que não têm poder para cumprir, dentro de sua própria agenda, um papel estruturante na elaboração de trabalhos que interferem no desenvolvimento do território.

Assim, a agenda ambiental acaba sendo o próprio reflexo destas práticas, por ser capaz de gerar boa mídia para uma administração, considerando-se que ela (a agenda ambiental) é um tema debatido mundialmente ${ }^{2}$.
${ }^{2} \mathrm{~A}$ agenda ambiental para esta dissertação é entendida como as demandas que os órgãos voltados à área ambiental se propõem a trabalhar de forma articulada ou separadamente. Sendo assim, estão voltadas a determinados eixos temáticos, tais como: educação ambiental, saneamento ambiental, licenciamento e fiscalização, sistema de espaços livres públicos, manejo e conservação dos recursos naturais, agricultura e manejo dos insumos agropecuários, além do sistema de avaliação, monitoramento e gerenciamento de informações integradas. 


\section{Ausência de matricialidade}

Outra questão a ser posta, com relação a sua real eficácia e capacidade de implementação, trata-se da prática vinculada à matricialidade, que é a habilidade que os órgãos administrativos possuem em trabalhar conjuntamente sobre um mesmo tema, como o transporte, o desenvolvimento econômico, a agricultura e etc.. Este pode ser considerado como um método que visa a potencialização de políticas públicas, através do trabalho integrado dos órgãos gestores.

Um de seus objetivos, entre outros, é proporcionar à população maiores benefícios, utilizando-se de uma quantidade menor de recursos, que, no entanto, por vezes não acontece em função das disputas, da falta de integração e de interesse por uma das partes. Assim, a sociedade acaba não recebendo todos os beneficios que Ihes resguardaria a qualidade de vida por direito, ou os recebem com restrições.

\section{Não aprovação dos projetos nas casas de leis}

Para que planos e projetos sejam analisados pelas casas de leis, estes percorrem inúmeras etapas como: a realização dos levantamentos de campo e coleta de dados para o entendimento do território; a superação de todos os entraves, barreiras, dificuldades técnicas, científicas, burocráticas e econômicas da gestão pública dentro do poder executivo; a mobilização e sensibilização da sociedade, além do desenvolvimento de diversos seminários junto às demais secretarias, diálogos voltados à construção dos planos com as equipes técnicas das prefeituras e conversas com as consultorias, a fim de chegar ao seu último destino. 
Apesar de todo este trabalho, o desfecho nem sempre é favorável à sociedade e ao ambiente, pois o destino final significa a chegada de todo o processo descrito anteriormente às Câmaras Municipais, aos Deputados, às Assembléias Legislativas e ao Senado, para que os projetos de lei sejam votados.

Em função de questões políticas partidárias, por muitas vezes nestas instituições, de forma perniciosa e autoritária, bons projetos de interesse da sociedade não são aprovados, trazendo imensos prejuízos para o território ${ }^{3}$.

\section{Políticas cosméticas}

Embora se tenha consciência da necessidade com relação à implementação de políticas estruturantes, ou seja, de planos, projetos e ações que realmente tenham a capacidade de intervir na vida da sociedade, por muitas vezes projetos fundamentais que tragam reais transformações acabam sendo deixados de lado, em função de prioridades "cosméticas", as quais trazem apenas um mero embelezamento urbano.

A exemplo do que se verifica, por vezes, a "boniteza" e a "belezura" dos projetos voltados a simples inserção de espécies, como forrações e plantas arbustivas, nas praças, parques, viadutos, calçadas, entre outros, ganham espaço no investimento da administração pública. Em contrapartida, projetos que realmente deveriam receber atenção como os que: criam novos espaços de recreação como praças e parques, requalificam as calçadas, prevêem a restauração ambiental de áreas ambientalmente significativas, que possuem uma vegetação luxuriante, acabam não sendo priorizados.
${ }^{3}$ Como exemplo citam-se dois trabaIhos: o Plano Diretor desenvolvido para Suzano e o Plano Integrado de Resíduos da Construção Civil e Volumosos, elaborado para Poá, Ferraz de Vasconcelos e Suzano, sendo que ambos não foram aprovados pela Câmara Municipal de Suzano, por comprometer interesses específicos, pontuais e individuais, ainda que tenham sido desenvolvidos de forma participativa pelo poder executivo, com vistas ao desenvolvimento equilibrado do território e respeito às suas características. Como exemplo, ainda que as Secretarias, responsáveis pela limpeza urbana, retirem parte do entulho lançado por caçambeiros e carroceiros, a ausência com relação à implantação desta política torna impossível a manutenção da cidade com relação a este tipo de resíduos. 
Observa-se que este conflito é eminente em qualquer parte, dada a própria demanda por parte da população que constantemente faz solicitações imediatistas desconexas entre si, com relação à manutenção estética da cidade, ficando o Poder Público, por vezes, refém dos pedidos. Este se vê, dessa forma, obrigado a atender as necessidades superficiais, sendo que poderia estar investindo os recursos públicos em políticas estruturantes, com alta capacidade de intervir na vida das pessoas, ainda que a longo prazo.

Assim, entende-se que ao falarmos de inserção de espécies decorativas em um trecho da cidade, existem políticas públicas que apresentam uma relevância muito maior, que simples plantios de elementos ornamentais. Como exemplo, citam-se os planos e ações de restauração ambiental que contemplem todo o território, com o objetivo claro de recuperar áreas que estejam degradadas, proteger corpos d'água através da implementação de matas ciliares, promover a conectividade de fragmentos de mata e/ou matrizes através de corredores ecológicos, criar áreas de borda em torno de matas existentes para sua proteção, valorizar áreas que possuem beleza cênica, contribuir para que um sistema de espaços livres planejados possa ser desenvolvido, entre tantas outras.

Ou seja, diante de territórios que possuem diversas características ambientais especiais, uma ação de embelezamento não é perniciosa, mas não pode ser a única ou a principal, sobre o sistema de espaços livres públicos.

Portanto, verifica-se que todos os aspectos comentados, tais como a composição dos cargos, a instabilidade das equipes, a falta de recursos financeiros, os entraves burocráticos, a disputa entre os órgãos administrativos, a não aprovação dos projetos nas casas de leis, as prioridades cosméticas, interferem na construção de 
políticas públicas que podem ser implantadas em todo o país, voltadas à estrutura paisagística, à implementação de espaços livres, à preservação, conservação e recuperação das florestas, bem como à valorização dos potenciais ambientais e ecológicos existentes.

Para tanto, considera-se que são inúmeras as políticas ambientais de grande relevância a serem implementadas em um território, como as voltadas a mudanças climáticas, ao saneamento ambiental, ao licenciamento e fiscalização ambiental, à educação ambiental, conservação dos recursos naturais, agricultura sustentável, ao sistema de avaliação, monitoramento e gerenciamento de informações integradas ambientais, à preservação dos recursos hídricos, entre tantas outras, mas que, no entanto, por muitas vezes são desprezadas, ignoradas e não incentivadas pelo Poder Público, por não trazerem reflexos diretos e imediatos no cotidiano das pessoas.

Mas, apesar de determinadas administrações públicas apresentarem as inúmeras deficiências, que foram expostas, há sem dúvida aquelas que são envolvidas com a temática ambiental, sendo que este comprometimento se expressa de diversas formas, ou seja, através:

- da indicação de pessoas para ocupar os cargos administrativos, que realmente possuem conhecimento técnico e científico;

- $\quad$ de concursos feitos, os quais têm a intenção de manter equipes estáveis para o desenvolvimento dos trabalhos, prevendo a contratação de pessoas com os mais variados conhecimentos dentro da área ambiental como engenheiros ambientais, gestores ambientais, biólogos, técnicos em gestão ambiental, 
engenheiros florestais, arquitetos e advogados especializados na área, entre outros;

- da disponibilização de recursos para que seus técnicos possam realizar cursos que visem sua constante formação;

- de recursos do Tesouro reservados e destinados à temática ambiental para o desenvolvimento de planos, projetos, ações e obras;

- da promoção de atividades como seminários e dinâmicas que visam promover a potencialização das políticas públicas, através da integração dos órgãos administrativos;

- da destinação compatível das agendas com os órgãos administrativos, ou seja, cada setor acaba fazendo realmente a gestão do tema que lhe compete;

- da aprovação de bons projetos nas casas de leis, favorecendo, dessa forma, o desenvolvimento das políticas;

- da implantação de políticas estruturantes, ou seja, aquelas que mudam e melhoram a vida das pessoas.

Entende-se, ainda, que a gestão ambiental sobre um território não se faz somente pelo Poder Público. Para além deste, 0 setor privado também contribui especialmente para esta gestão, em função de seus interesses, voltados, por exemplo, à produção incessante dos bens de consumo, às oportunidades de grandes lucros, aos desejos do mercado imobiliário, os quais produzem alterações que infligem negativamente sobre a natureza, ocasionando processos irreversíveis.

É a gestão privada que de fato constrói a paisagem, com seus investimentos na agricultura, na urbanização, na indústria, no comércio e etc., possuindo, dessa forma, um papel extremamente significativo na ocupação de um território, os quais são expressos, 
por exemplo, pela construção das indústrias, que por muitas vezes induzem a implantação de novos loteamentos, aberturas de comércio, atividades vinculadas a reflorestamentos e, também, por ações que em diversos momentos degradam o meio ambiente ao promoverem o desvio, a canalização e a supressão de corpos d'água, visando atender interesses imediatos de determinados proprietários.

Nesse sentido, constata-se que a iniciativa privada não incorpora, em vários momentos, no seu cotidiano, procedimentos e ações que trabalhem em conformidade com critérios paisagísticos e ambientais desejáveis, cabendo ao Poder Público cumprir a sua parte, através de ações, de fiscalização, considerando-se que é o Estado que possui a responsabilidade de regular, gerenciar e implementar politicas públicas ambientais que resguardem o "solo".

Assim, o desenvolvimento de um território não é uma "via de mão única" que sofre interferências, intervenções e ações somente do Poder Público. 0 que se verifica é que, em geral, setores da sociedade privada possuem total desprezo ou ignorância, bem como ausência de preocupação pela paisagem e ambiente de um território.

Dessa forma, não é possivel culpar somente o Poder Público pela falta de "desenvolvimento equilibrado", pois o setor privado, bem como a sociedade em geral com a sua omissão constante, seja de maneira coletiva ou individual, também possui sua parcela de culpa.

Como resultado da atuação, tanto do Poder Público quanto do setor privado, observa-se, em diferentes pontos do país, os chamados desastres naturais, tais como deslizamentos e enchentes 
em função da urbanização se dar de uma maneira inadequada no que se refere ao uso do solo.

No Brasil, bem como em outros países, em geral, não estão previstas medidas que evitem estes problemas, mas sim a constante postura de incentivos e permissões quanto às ocupações inadequadas em áreas ambientalmente protegidas, por razões eleitoreiras.

Os incentivos também acontecem por parte do mercado imobiliário informal, que vende terras ambientalmente protegidas por valores abaixo do mercado formal, utilizando-se da falta de conhecimento e disponibilidade financeira das pessoas.

Os critérios adequados para o assentamento urbano, assim como a drenagem urbana, os resíduos sólidos, o abastecimento de água e o esgotamento sanitário, temas de alçada do saneamento ambiental, raramente possuem o devido destaque nas políticas públicas ambientais, causando assim intensos danos, em longo prazo, por todo o país.

0 que se verifica, através de todas as explanações expostas sobre a paisagem, é que a sociedade sempre age sobre ela, buscando processá-la para atingir seus objetivos.

Objetivos estes geradores de conflitos que acabam sendo inadequados para a nossa vida, como a contaminação das águas. Alguns deles sensibilizam a sociedade por serem mais visíveis, possuirem a capacidade de transformar de forma imediata a paisagem e o cotidiano. No entanto, outros são imperceptíveis e, por isso, acabam sendo ignorados. 


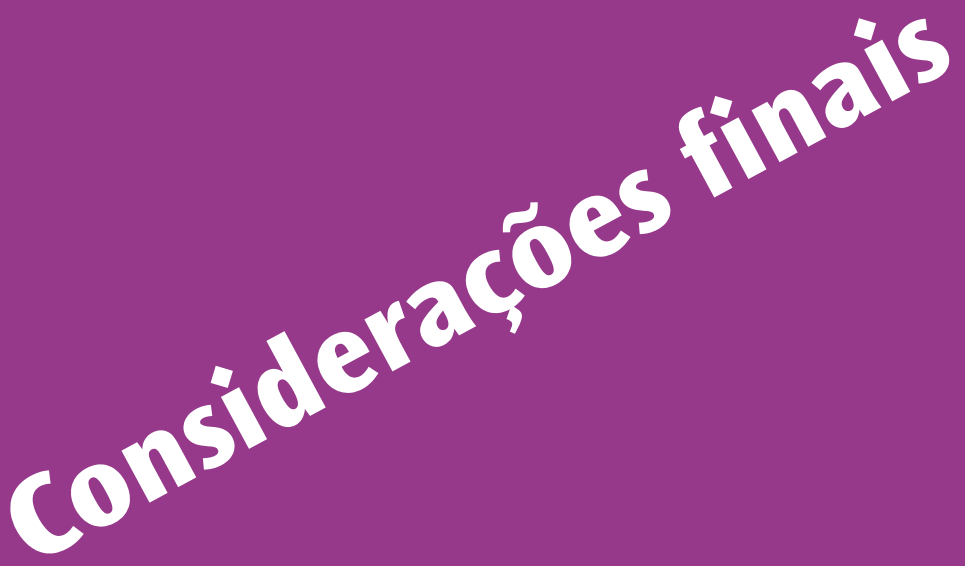





\section{Considerações finais}

Ao analisarmos, em um mesmo contexto, as identidades naturais e as criadas, percebemos que, embora o território possua lugares magníficos sob o aspecto paisagístico, como a região de Palmeiras, a Represa de Taiaçupeba e a APA do Tietê, estas não foram exploradas de forma a valorizar os espaços criados do território, não incentivando, consequentemente, a convivência da população com os recursos naturais.

Nesse sentido, observa-se que a gestão pública até então (2012) pouco soube aproveitar as oportunidades ambientais e ecológicas que o território oferece, entre elas as possibilidades de conectividade entre os diversos elementos florestais existentes, que poderiam se constituir em fatores de interesse para a produção de um sistema de espaços livres públicos ecologicamente correto e urbanisticamente interessante.

0 estudo mostra que, embora o município de Suzano tenha uma atividade industrial e comercial importante, a maior parcela da população vive em condições insatisfatórias do ponto de vista urbanístico e ambiental, o que leva à constatação de que houve ausência, ao longo de muitos anos, de políticas de governo para estas temáticas, que começaram a ser refletidas e dialogadas, ainda de um modo incipiente, somente a partir de 2005.

Verificamos que para o municipio o desenvolvimento e o crescimento urbano não coincidiram e que, por sua vez, o crescimento econômico não conduziu automaticamente ao desenvolvimento de um sistema de espaços livres adequado às demandas latentes da população. 
A análise empírica do território demonstra claramente este fato quando avaliamos a forma como as expansões urbanas se deram ao longo do município. Observamos que o crescimento foi quantitativo, explicitado pelo aumento dos loteamentos. No entanto, como grande parte das áreas ocupadas foram locais ambientalmente frágeis, como as compreendidas dentro da APM, estas acabaram impedidas por lei de receber infraestrutura, não permitindo o desenvolvimento equilibrado.

A degradação ambiental está, na maioria dos casos, relacionada às ocupações conflitantes do território, o que compromete drasticamente a oferta de recursos e serviços ambientais, apresentando influência direta na qualidade urbana e natural.

Tem-se, como exemplo, os loteamentos situados no distrito de Palmeiras, que possuem uma situação de oposição e, consequentemente, conflitante com relação à tendência natural da região, já que as ocupações representam o comprometimento tanto do abastecimento de água para todo o município, como das áreas florestadas, que deveriam ser preservadas, tendo como premissa a conservação ambiental.

A análise demonstra que a "lógica" das ocupações no município em questão e as consequências resultantes deste processo foram negativas e intangiveis. 


\section{0 não planejamento e a omissão}

Os reflexos do não planejamento por tanto tempo resultaram, desta maneira, na escassez de espaços livres públicos qualificados, na ausência de saneamento em grande parte do território, na precariedade quanto às condições de habitabilidade e nas agressões junto às florestas e águas.

Alguns exemplos: a conivência do poder público com relação à poluição das águas e o não aproveitamento do partido paisagístico que a Represa de Taiaçupeba oferece para o desenvolvimento de uma orla capaz de abrigar espaços com características propícias para lazer, recreação e contemplação. 0 u seja, as potencialidades ambientais e paisagisticas foram ignoradas, na medida em que 0 município e o Estado não proporcionaram qualquer destinação específica para atender às demandas latentes voltadas à recreação da população e à conservação dos seus recursos, assim como ao embelezamento da paisagem do território.

Situação esta sustentada, por um lado, pela falta de interesse e conhecimento que fossem pautados em ações, planos e projetos, que considerassem de fato a paisagem e o meio ambiente; e, por outro, pela presença de ações que se concentraram apenas no desenvolvimento de projetos pontuais e casuisticos, as quais visaram 0 atendimento de solicitações simplesmente políticas para atender a alguns segmentos da sociedade, em detrimento de outros.

Essas intervenções, por sua vez, geram padrões distintos de expansões territoriais, como demonstra o corte esquemático, através da implantação dos loteamentos edificados, das indústrias, do cultivo de eucalipto e da agricultura, propiciando degradações junto ao sistema hídrico e às matas, pois, por muitas vezes, estas 
ocupações se instalam sobre estes recursos, exigindo a sua supressão quando se trata de fragmentos florestais, ou até mesmo que sejam desviados, quando se referem aos corpos d'água.

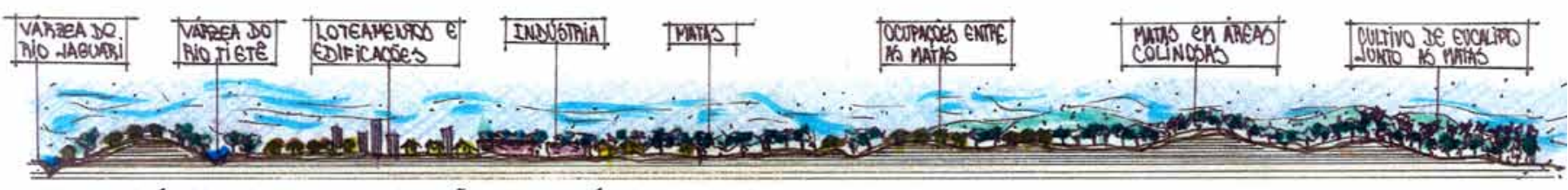

ESQUEMA GRÁFICO DAS FORMAS DE OCUPAÇÃO NO TERRITÓRIO DE SUZANO

Corte que demonstra os padrões distintos de expansão territorial Fonte: Desenho criado por Michele de Sá Vieira, 2011

Neste contexto, a gestão pública local evidenciou o completo descaso pelos recursos naturais. Ou seja, a paisagem deste território foi vista pelos gestores públicos como um produto totalmente desvinculado das questões paisagísticas e ambientais, o que acabou por estabelecer uma série de conflitos, causando prejuizos tais como: a poluição das águas e o descarte irregular de resíduos.

Desta forma, o ambiente passou a ser prejudicado através das práticas de degradação ambiental, as quais refletiram diretamente na vida da população em função da:

- alteração das características do meio ambiente, vinculadas aos solos, às águas, à vegetação, à atmosfera, que, dessa forma, prejudicam a saúde, a segurança e o bem-estar da população;

- criação de situações adversas às atividades sociais e econômicas, que descaracterizam a biota e estimulam alterações que comprometem a estética do meio ambiente . 
Ou seja, as intervenções geradas por empreendimentos urbanos sobre o território, que por vezes interrompem e desviam o sistema hídrico, prejudicam o fluxo deste, gerando problemas na produção da água, bem como interferências junto à perpetuação da biodiversidade.

Esta é uma característica da região metropolitana paulista e de Suzano, que vivenciam inúmeros conflitos ambientais, como a contaminação e destruição dos ecossistemas das áreas vinculadas aos seus mananciais.

Sendo assim, a territorialidade urbana de Suzano, em 2012, é expressa através de tensões, legalidades, usos e complexidades socioculturais e socioambientais, que acontecem tanto sobre este município como em qualquer outro.

\section{Os desafios}

A gestão municipal possui o desafio de evoluir para uma política não convencional, que vise resgatar as funções ecológicas, 0 uso sustentável da água e o direito à paisagem, objetivando atender aos mais diversos interesses.

Além disso, torna-se fundamental que se comprometa com as políticas que envolvem toda a Região Metropolitana de São Paulo, através do estabelecimento de planos capazes de estimular novas formas de uso e ocupação do solo, propiciando, assim, uma nova estruturação da paisagem pautada em princípios ecológicos. 


\section{Como avançar}

Para que a sustentabilidade do território seja resguardada, será necessário trabalhar para a manutenção e a ampliação da interconexão entre os elementos da paisagem, dentro dos princípios da Ecologia de Paisagens.

Compreende-se que a adoção de critérios paisagísticos-ambientais dentro do planejamento municipal deva ser priorizada, objetivando controlar perdas e acrescentar valores nos processos de urbanização, através:

- da preservação dos sistemas ambientais, representados pela água, ar, solo e ecossistemas, mantendo-os saudáveis e acessiveis à população;

- do controle da poluição difusa sobre o ar e a água, objetivando a não geração de distúrbios em relação a eles;

- de ações que minimizem a vulnerabilidade humana, a partir da implementação do saneamento ambiental adequado, objetivando resguardar as condições ideais voltadas à nutrição e à saúde;

- da ampliação da capacidade socioinstitucional, visando implementar habilidades, atitudes e redes que sensibilizem e estimulem a sociedade, quanto à superação dos desafios ambientais;

- da atuação sobre a responsabilidade regional, que compreende nos esforços voltados a cooperação compartilhada, colaborando para sanar os problemas ambientais comuns a dois ou mais territórios, no intuito de reduzir os transbordamentos de impactos ambientais de um município para o outro.

Ou seja, todas as considerações colocadas acima devem ser tratadas de forma conjunta, pela gestão púbica, para evitar danos imensuráveis sobre o território como a degradação dos solos, concentração e emis- 
são de metais pesados, fragmentação dos ecossistemas, impactos quanto à disposição de resíduos sólidos e exploração predatória da fauna e flora.

A partir deste entendimento, compreende-se que o município deve ser repensado, para que as criações humanas, vistas como adaptações convenientes aos lugares, possam realçar as qualidades naturais intrínsecas deste território, tais como clima, vegetação, morfologia, pedologia e fauna, contribuindo, dessa maneira, para o embelezamento da paisagem, que surgirá nas ocasiões em que houver o reconhecimento dos reais valores presentes em Suzano.

Nesse sentido existem possibilidades de ações que podem estabelecer novos desenhos como a transformação de grandes várzeas, a exemplo do Rio Tietê e da Represa de Taiaçupeba, em parques lineares, que oferecem diversas alternativas de lazer e contemplação, principalmente aos grupos que estão no entorno destes espaços. Ou seja, a criação de grandes intervenções é essencial para o desenvolvimento ambiental e urbanístico desse território.

Apesar de todas as questões postas, ainda é possivel vencer os descompassos presentes, sendo que a proposta de um sistema de espaços livres públicos, que leve em consideração as machas de vegetação ainda existentes no território, é uma oportuna medida para que a superação dos conflitos ambientais e urbanísticos aconteça. 


\section{O Poder Público}

Cabe ao Poder Público, junto à sociedade civil organizada e aos movimentos sociais, buscar instrumentos que sejam capazes de atuar na produção do espaço, suscitando movimentos que possibilitem resolver os problemas existentes entre as relações físicas, sociais e econômicas no território de Suzano. Este deverá verificar em que medida a criação das políticas públicas poderá trabalhar como fator indutor na solução dos problemas estabelecidos, analisando quais seriam os instrumentos de gestão e as estruturas administrativas a serem criadas e organizadas para sustentar e garantir melhores condições de habitabilidade, além do uso racional e sustentado dos espaços, o ordenamento equilibrado do território, bem como a manutenção, recuperação e preservação dos recursos naturais.

A gestão pública tem de mediar os conflitos que surgem constantemente, sejam dos movimentos sociais ou das tensões territoriais, utilizando-se de planos, projetos, ações e programas que tragam ganhos políticos e materiais para a sociedade, através de políticas públicas com capacidade de moldar os problemas existentes, principalmente pelo fato de ser ela a detentora do poder de fiscalização sobre o território.

Diante da atual realidade nos resta somente conjecturar sobre qual cidade teriamos hoje, se ela tivesse sido pensada em sua totalidade a partir de um desenvolvimento gradual, onde cada elemento houvesse sido proposto no intuito de agregar interesses coletivos, desejos e aspirações de cada um e não à ambição predatória de indivíduos múltiplos, coordenados para atender a aspirações pontuais. 


\section{Cenários}

A meta do Poder Público, portanto, deveria ser 'trabalhar para contribuir com o aumento da qualidade de vida', que se expressa através da distribuição equilibrada da renda, acesso à habitação adequada, à mobilidade, educação, cultura e conservação da natureza.

Este arranjo ideal, a partir de um planejamento específico, permitiria de uma forma mais aprofundada o contato da população com as estruturas ambientais e as dinâmicas ecológicas existentes. 0 que se constata é que esta situação de valorização da identidade natural do município somente se dará no futuro, caso ocorra a produção de espaços livres em escalas e distribuições adequadas pelo território, o que influenciará, dessa maneira, não somente na adoção de novas formas de sociabilidade, mas também na criação de novos valores paisagísticos.

Entende-se que todas as escalas de abordagem devem ser contempladas, ou seja, tanto as pontuais, que colaboram para o embelezamento da cidade, quanto as territoriais, já que oferecem sem dúvida oportunidades muito mais amplas tanto para o uso humano quanto para a conservação dos recursos naturais.

As ações de planejamento municipais deveriam abordar os princípios relacionados com o sistema de valores ambientais existente, que obviamente está ligado aos recursos naturais para que, dessa forma, passem a ser determinantes na constituição adequada da forma do território.

Além dos recursos hídricos, a valorização das matas também deveria ser considerada por ter a capacidade de estruturar o solo, 
melhorar a drenagem e permeabilidade, equilibrar o clima e a manutenção da biodiversidade.

Diante de todas as exposições feitas, observa-se que o Estado não cumpriu, em momentos diversos, seu papel com relação aos recursos naturais, fato este que se deu em função: de uma real falta de demanda pela população local, das prioridades políticas, dos recursos orçamentários insuficientes para atender a todas as necessidades do município, bem como dos interesses difusos e não prioritários com relação à temática ambiental.

Por considerar que as cidades são, potencialmente, territórios de riqueza e diversidade ambiental, econômica, politica e cultural, movidas por atores sociais capazes de modificar a realidade local diante da atuação e, consequentemente, provocar a transformação de seus espaços físicos, é que se vê a grande necessidade quanto à implantação de políticas estruturadoras, ou seja, daquelas que realmente possuem a capacidade de mudar e melhorar a vida das pessoas cabendo, assim, aos gestores públicos, envolvidos com 0 meio ambiente, exercerem o seu papel junto à sociedade que os colocou no poder. 


\section{Referências bibliográficas}

\section{Referências bibliográficas citadas}

AFONSO, C. M.. A paisagem da baixada santista: Urbanização, transformação e conservação. São Paulo: Edusp/ FAPESP, 2006.

ARRIGHI, G.. O longo século XX: Dinheiro, poder e as origens de nosso tempo. São Paulo: UNESP, 1996.

BONILHA, I.. O desenho da paisagem à beira-rio e as metamorfoses da várzea do Tietê na cidade de São Paulo. Dissertação (Mestrado) - Faculdade de Arquitetura e Urbanismo, Universidade de São Paulo. São Paulo. 2002.

CHRISTOFOLETTI, A.. Modelagem de sistemas ambientais. São Paulo: Edgard Blucher, 1999.

DRAMSTAD, W. E; OLSON, J. D.; FORMAN, R. T. T.. Landscape ecology principles in landscape architecture and land-use planning. Washington: Harvard University, 1996.

HARVEY, D.. A condição pós-moderna: Uma pesquisa sobre as origens da mudança cultural. São Paulo: Loyola, 1993.

LEFF, H.. Saber ambiental: Sustentabilidade, racionalidade, complexidade e poder. Petrópolis, RJ: Vozes, 2001.

MACEDO, S. S.. Paisagem, urbanização e litoral do éden à cidade. Tese (Livre-Docência) - Faculdade de Arquitetura e Urbanismo, Universidade de São Paulo. São Paulo, 1993.

. Quadro do Paisagismo no Brasil. São Paulo: FAUUSP, 1999. (Coleção Quapá.)

\&t QUEIROGA, E. F.. Os sistemas de espaços livres e a constituição da esfera pública contemporânea no Brasil. São Paulo: FAUUSP, 2011. (Relatório de Pesquisa-Quapá.)

PELLEGRINO, P. R. M.. Paisagens temáticas: Ambiente virtual. Tese (Doutorado) - Faculdade de Arquitetura e Urbanismo, Universidade de São Paulo. São Paulo. 1995.

PROJETO ORLA: Fundamentos para gestão integrada. Brasília: MMA/SQA; Brasília: MP/SPU, 2002.

PROJETO ORLA: Manual de gestão. Brasília: MMA/SQA; Brasilia: MP/SPU, 2002.

SAKATA, F. G. Paisagismo urbano: Requalificação e criação de imagens. São Paulo: Edusp, 2011.

SANTOS, M. A natureza do espaço. São Paulo: Hucitec, 1996.

TÂNGARI, V. R.; ANDRADE, R.; SCHLEE, M. B. (orgs.). Sistema de Espaços Livres: o cotidiano, apropriações e ausências. 1a. ed. Rio de Janeiro: Universidade Federal do Rio de Janeiro/PROARO FAUUFRJ, 2009.

VEIGA, J. E.. Desenvolvimento sustentável. O desafio do século XXI. Rio de Janeiro: Garamond Universitária, 2005.

YÁZIGI, E.. Turismo e paisagem. São Paulo: Contexto, 2002. 


\section{Referências bibliográficas de apoio}

ARRIGHI, G.. Adam Smith em Pequim. Origens e fundamentos do século XXI. São Paulo: Bontempo Editorial, 2008.

BRESSER-PEREIRA, L.C.. Desenvolvimento e crise no Brasil: História, economia e política de Getúlio a Lula. São Paulo: Editora 34, 2003.

CARNOY, M.. Estado e teoria política. Campinas, SP: Papirus, 1989.

CHACEL, F.. Paisagismo e Ecogênese. Rio de Janeiro: Fraiha, 2004.

COMITÊ da Bacia Hidrográfica do Alto Tietê. Plano da Bacia do Alto Tietê. Relatório Final. Setembro 2002.

GEHL, J.; GEMZOE, L.. Nuevos espacios urbanos. Barcelona: Gustavo Gili, 2002.

HOUGH, M.. Naturaleza y ciudad. Planificación Urbana y Processos Ecológicos. Barcelona: Gustavo Gili, 1998 (1995).

LEENHARDT, J. (org.). Nos jardins de Burle Marx. São Paulo: Perspectiva, 1994.

LEFÉBVRE, H.. Espaço e política. (Trad. Margarida M. Andrade e Sérgio Martins). Belo Horizonte: UFMG, 2008.

LOUREIRO, C. F. B.. O movimento ambientalista e o pensamento crítico. Rio de Janeiro. Quartet, 2003.

MALACO, J. T. S.. Da forma urbana: 0 casario de Atenas. São Paulo: Alice Foz, 2002.

MARTINS, M. L. R.. Moradia e mananciais, tensão e diálogo na metrópole. São Paulo: FAUUSP/FAPESP, 2006.

MC'HARG. I.. Proyectar con la naturaleza. Barcelona: Gustavo Gili, 2000.

MOLLINGA, P.P.. Water, politics and development: Framing a political sociology of water resources management, water alternatives. v. 1, n.1, p. 7-23, 2008.

MORSELLO, C.. Áreas protegidas públicas e privadas: Seleção e manejo. São Paulo: Annablume/ Fapesp, 2001.

OLIVEIRA, F.. A navegação venturosa: Ensaios sobre Celso Furtado. São Paulo: Bontempo Editorial, 2003.

PELLEGRINO, P. R. M.. Paisagem e ambiente: Um processo de aproximação no setor oeste da macrometrópole de São Paulo. Dissertação (Mestrado) - Faculdade de Arquitetura e Urbanismo, Universidade de São Paulo. São Paulo, 1987.

. Poder Público, decisão técnica e cidadania. In: Democratic strategies for the production of the built environment. v.1. São Paulo: Proceedings/ FAUUSP, 1992.

. Pode-se planejar a paisagem? Paisagem e Ambiente? In: Paisagem e Ambiente - Ensaios. v. 13. São Paulo: FAUUSP, 2000.

PHILIPPI, A.. Saneamento, saúde e ambiente: Fundamentos para um desenvolvimento sustentável. Barueri, SP: Manole, 2005.

Prefeitura Municipal de Suzano. Plano Municipal de Abastecimento de Água e Esgotamento Sanitário. v. 1. Junho, 2008. 
. Revisão do Plano Diretor de Suzano 2006-2016. Etapa 4 - Construção do conhecimento sobre a realidade local. v. 1. Janeiro, 2007.

. Plano Diretor de Macrodrenagem, 2008.

REBOUÇAS, A. C. \& BRAGA, B. \& TUNDISI, J. G.. Águas doces do Brasil: Capital ecológico, uso e conservação. São Paulo: Escrituras Editora, 1999.

RODRIGUES, R. R. \&t FILHO, H. F. L.. Matas ciliares: Conservação e recuperação. 2a. ed.. São Paulo: Edusp/ Fapesp, 2001.

SANTOS, R. F.. Planejamento ambiental: Teoria e prática. São Paulo: Oficina de Textos, 2004.

SAULE, J. N. (org.). Direito urbanístico - vias jurídicas das políticas urbanas. Porto Alegre: Sergio Antonio Fabris Editor, 2007.

SPIRN, A.. O jardim de granito - A natureza no desenho da cidade. São Paulo: Edusp, 1996.

TOPALOV, C.. La urbanización capitalista. México: Edicol, 1970.

VIGILAR, J.M.M.. Interesses individuais homogêneos e seus aspectos polêmicos. São Paulo: Saraiva, 2003.

YÁZIGI, E.; CARLOS, A. F. A.; CRUZ, R. C. A. (orgs.). Turismo: Espaço, paisagem e cultura. São Paulo: Hucitec, 1996.

\section{Referências de legislações}

BRASIL, República Federativa do - Lei Federal n. 6.938/81 (Dispõe sobre a Política Nacional do Meio Ambiente, seus fins e mecanismo de formulação e aplicação, e dá outras providências), Brasília, 1981.

BRASIL, República Federativa do - Resolução Federal CONAMA n. 1/86 (Dispõe sobre procedimentos relativos ao Estudo de Impacto Ambiental), Brasília, 1986.

BRASIL, República Federativa do - Lei Federal n. 9.985/2000 (Regulamenta o art. 225, § 1², incisos I, II, III, e VII da Constituição Federal, institui o Sistema Nacional de Unidades de Conservação da Natureza e dá outras providências), Brasília, 2000.

SÃO PAULO, Estado de - Lei Estadual n. 898/75 (Disciplina o uso de solo para a proteção dos mananciais, cursos e reservatórios de água e demais recursos hídricos de interesse da Região Metropolitana da Grande São Paulo e dá providências correlatas), São Paulo, 1975.

SÃO PAULO, Estado de - Lei estadual n. 1.172/76 (Delimita as áreas de proteção relativas aos mananciais, cursos e reservatórios de água, a que se refere 0 artigo $2^{\circ}$ da Lei Estadual n. 898, 18 de dezembro de 1975, estabelece normas de restrição do uso do solo em tais áreas e dá providências correlatas), São Paulo, 1976.

SÃO PAULO, Estado de - Lei Estadual n. 5.598/87 (Declara Área de Proteção Ambiental regiões urbanas e/ou rurais dos municípios de Salesópolis, Biritiba Mirim, Moji das Cruzes, Suzano, Poá, Itaquaquecetuba, Guarulhos, São Paulo, Osasco, Barueri, Carapicuíba e Santana do Parnaíba), São Paulo, 1987. 
SÃO PAULO, Estado de - Lei Estadual n. 7663/91 (Estabelece normas de orientação à Política Estadual de Recursos Hídricos, bem como ao Sistema Integrado de Gerenciamento de Recursos Hídricos), São Paulo, 1991.

SÃO PAULO, Estado de - Lei Estadual n. 9.866/97 (Dispõe sobre diretrizes e normas para a proteção e recuperação das bacias hidrográficas dos mananciais de interesse regional do Estado de São Paulo e dá outras providências), São Paulo, 1997.

SÃO PAULO, Estado de - Decreto Estadual n. 43.022/98 (Regulamenta dispositivos relativos ao Plano Emergencial de Recuperação dos Mananciais da Região Metropolitana da Grande São Paulo, de que trata a Lei $n$. 9.866, de 28 de novembro de 1997, que dispõe sobre diretrizes e normas para a proteção e a recuperação dos mananciais de interesse regional do Estado de São Paulo e dá providências correlatas), São Paulo, 1998.

SÃO PAULO, Estado de - Lei Estadual n.12.183/05 (Dispõe sobre a cobrança pela utilização dos recursos hídricos do domínio do Estado de São Paulo, os procedimentos para fixação dos seus limites, condicionantes e valores e dá outras providências), São Paulo, 2005.

SUZANO, Município de - Lei Complementar Municipal n. 025/96 (Dispõe sobre a divisão do território do município em zonas de uso; regula o parcelamento e a ocupação do solo; dispõe sobre os imóveis e as edificações em gera, e dá outras providências), Suzano, 1996.

\section{Referências de endereços eletrônicos}

Comitê da Bacia Hidrográfica do Alto Tietê (CBH-AT). Disponivel em: <http://www.comiteat.sp.gov.br/>. Acesso em: 22 de fev. 2012.

Companhia de Saneamento Básico do Estado de São Paulo (Sabesp). Disponivel em: <http://www.bnamericas. com/company-profile/en/Companhia_de_Saneamento_Basico_do_Estado_de_Sao_Paulo_S,A,-Sabesp>. Acesso em: 22 de fev. 2012.

Departamento de Águas e Energia Elétrica (DAEE). Disponivel em: <http://www.daee.sp.gov.br/>. Acesso em: 22 de fev. 2012.

Departamento de Avaliação de Impacto Ambiental (DAIA). Disponível em: <http://homologa.ambiente.sp.gov.br/ cprn/sobre_daia.htm>. Acesso em: 22 de fev. 2012.

Fundação Agência da Bacia Hidrográfica do Alto Tietê (FABHAT). Disponivel em: <http://www.fabhat.org.br/site/ index.php>. Acesso em: 22 de fev. 2012.

Google maps. Disponivel em: <http://www.google.com.br/search?hl=pt- BR\&tsource=hp\&tq=google+maps\&tgbv=

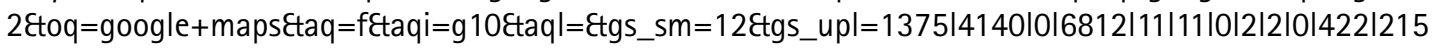
6l2-2.2.2|6|0>. Acessos em 2011 e 2012.

Instituto Brasileiro de Geografia e Estatística (IBGE). Disponível em: <http://www.ibge.gov.br/cidadesat/painel/ painel.php?codmun=355250>. Acesso em 06 de jun. 2011. 
Infraestrutura verde. Disponivel em: <http://www.urbansystems.com.br/noticias/ler/imoveis-cdhu-promove-oficina-sobre-infra-estrutura-verde >. Acesso em 6 fev. 2012

MACEDO S. S. (Org.). Sistema de espaços livres da cidade contemporânea brasileira e a esfera de vida publica considerações preliminares. São Paulo: IEB-USP, 2009. Disponivel em: <http://egal2009.easyplanners. info/area05/5156__CUSTODI0_Vanderli.doc>. Acesso em: 10 abr. 2011. p 3.

METZGER, J. P.. 0 que é ecologia de paisagens? In: Biota Neotropica. v.1 (n.1) BN00701122001, 2001. Disponível em: <http://www.biotaneotropica.org.br/v1n12/pt/fullpaper?bn00701122001+pt>. Acesso em: 14 de jan. 2012.

Prefeitura Municipal de Suzano. Disponivel em: <http://www.suzano.sp.gov.br/CN04/secretarias.asp>. Acesso em: 22 de fev. 2012.

Secretaria Estadual do Meio Ambiente (SMA). Disponivel em: <http://www.ambiente.sp.gov.br/>. Acesso em: 22 de fev. 2012.

Subcomitê da Bacia Hidrográfica do Alto Tietê Cabeceiras (SBH-ATC). Disponivel em: <http://www.tietecabeceiras.com.br/institucional/sobre-o-sub-comite>. Acesso em: 16 de jan. 2012.

VILLAÇA, F. Dilemas do Plano Diretor. Disponivel em: <http://www.ongcidade.org/site/arquivos/artigos/

dilemas436f9e94d59fb.pdf>. Acesso em: 31 de abr. 2011.

\section{Entidades consultadas}

Agência Ambiental de Mogi das Cruzes

Comitê da Bacia Hidrográfica do Alto Tietê

Prefeitura Municipal de Suzano

Sabesp - Companhia de Saneamento Básico do Estado de São Paulo

Secretaria de Saneamento e Recursos Hídricos

Subcomitê da Bacia Hidrográfica do Alto Tietê Cabeceiras 


\section{Anexo}

\section{Órgãos administrativos: Estrutura}

\section{Esta tabela mostra quais são os órgãos gestores, bem como suas funções, algumas ações e órgãos} vinculados a eles, que contribuem para a política de implantação e manutenção dos espaços livres públicos do município.

\begin{tabular}{|c|c|c|c|c|c|}
\hline Recorte & Órgãos Gestores & Funções & Órgãos vinculados & Funções & Ações \\
\hline \multirow[t]{5}{*}{ Estado } & \multirow[t]{2}{*}{$\begin{array}{l}\text { Comitê da Bacia } \\
\text { Hídrográfica do Alto } \\
\text { Tietê (CBH - AT), } \\
\text { trata-se de um } \\
\text { órgão colegiado, } \\
\text { criado pela Lei n. } \\
7663 / 91 \text {, de caráter } \\
\text { consultivo e } \\
\text { deliberativo que } \\
\text { compõe o Sistema } \\
\text { Integrado de } \\
\text { Recursos Hídricos - } \\
\text { SIGRH, com atuação } \\
\text { na Bacia } \\
\text { Hidrográfica do Alto } \\
\text { Tietê }\end{array}$} & \multirow[t]{2}{*}{$\begin{array}{l}\text { Promover o } \\
\text { gerenciamento } \\
\text { descentralizado, } \\
\text { participativo e integrado } \\
\text { dos recursos hídricos } \\
\text { sem dissociação dos } \\
\text { aspectos quantitativos e } \\
\text { qualitativos em sua área } \\
\text { de atuação, além disso o } \\
\text { Comitê adota a bacia } \\
\text { hidrográfica, como } \\
\text { unidade físico territorial } \\
\text { de planejamento e } \\
\text { gerenciamento }\end{array}$} & $\begin{array}{l}\text { Subcomitê da Bacia } \\
\text { Hidrográfica do Alto Tietê } \\
\text { Cabeceiras } \\
\text { (SBH - ATC), é um órgão } \\
\text { colegiado, descentralizado, } \\
\text { de caráter consultivo e } \\
\text { deliberativo, vinculado ao } \\
\text { Comitê da Bacia Hidrográfica } \\
\text { do Alto Tietê, criado pela Lei } \\
\text { n. 7663/91. Este Subcomitê é } \\
\text { composto pela } \\
\text { Câmara Técnica de } \\
\text { Planejamento, } \\
\text { Câmara Técnica de Educação } \\
\text { Ambiental, } \\
\text { Grupo Técnico de } \\
\text { Monitoramento Hidrológico }\end{array}$ & $\begin{array}{l}\text { Promover o gerenciamento } \\
\text { descentralizado, } \\
\text { participativo e integrado } \\
\text { dos recursos hídricos na } \\
\text { Sub-Região Cabeceiras. } \\
\text { Além disso, deve-se } \\
\text { implantar, em sua área de } \\
\text { atuação, uma Política de } \\
\text { Proteção e Recuperação } \\
\text { dos Mananciais, } \\
\text { compatibilizando as ações } \\
\text { de preservação dos } \\
\text { mananciais de } \\
\text { abastecimento e as de } \\
\text { proteção ao meio } \\
\text { ambiente com o uso e } \\
\text { ocupação do solo e o } \\
\text { desenvolvimento } \\
\text { socioeconômico }\end{array}$ & $\begin{array}{l}\text { Produção: das Leis } \\
\text { Específicas, do futuro Plano } \\
\text { de Desenvolvimento de } \\
\text { Proteção Ambiental (PDPA), } \\
\text { bem como do } \\
\text { Protocolo em Defesa da } \\
\text { Recuperação da Qualidade } \\
\text { Socioambiental da Bacia } \\
\text { Hidrográfica do Alto Tietê } \\
\text { Cabeceiras, entre outras. }\end{array}$ \\
\hline & & & $\begin{array}{l}\text { Fundação Agência da Bacia } \\
\text { Hidrográfica do Alto Tietê - } \\
\text { (FABHAT) }\end{array}$ & $\begin{array}{l}\text { Ser o órgão executivo do } \\
\text { Comitê da Bacia } \\
\text { Hidrográfica do Alto Tietê, } \\
\text { na realização das políticas } \\
\text { estabelecidas pelo Comitê }\end{array}$ & $\begin{array}{l}\text { Produção: das Leis } \\
\text { Específicas, do futuro Plano } \\
\text { de Desenvolvimento de } \\
\text { Proteção Ambiental (PDPA), } \\
\text { entre outras. }\end{array}$ \\
\hline & \multirow[t]{2}{*}{$\begin{array}{l}\text { SABESP - } \\
\text { Companhia de } \\
\text { Saneamento Básico } \\
\text { do Estado de São } \\
\text { Paulo }\end{array}$} & \multirow{2}{*}{$\begin{array}{l}\text { Trata-se de uma } \\
\text { empresa de economia } \\
\text { mista, responsável pelo } \\
\text { fornecimento de água, } \\
\text { coleta e tratamento de } \\
\text { esgotos de } 364 \\
\text { municípios do Estado de } \\
\text { São Paulo }\end{array}$} & $\begin{array}{l}\text { Estações de Tratamento de } \\
\text { Água }\end{array}$ & $\begin{array}{l}\text { Assegurar os serviços de } \\
\text { abastecimento de água }\end{array}$ & \multirow[t]{3}{*}{$\begin{array}{l}\text { Garantir a universalização } \\
\text { dos serviços de água e esgoto }\end{array}$} \\
\hline & & & $\begin{array}{l}\text { Estação de Tratamento de } \\
\text { Esgotos }\end{array}$ & $\begin{array}{l}\text { Assegurar os serviços } \\
\text { vinculados ao esgotamento } \\
\text { sanitário }\end{array}$ & \\
\hline & $\begin{array}{l}\text { DAEE - } \\
\text { Departamento de } \\
\text { Águas e Energia } \\
\text { Elétrica (órgão } \\
\text { gestor dos recursos } \\
\text { hídricos do Estado } \\
\text { de São Paulo) }\end{array}$ & $\begin{array}{l}\text { Estabelecer a política de } \\
\text { utilização dos recursos } \\
\text { hídricos, tendo em vista } \\
\text { o desenvolvimento } \\
\text { integral das bacias } \\
\text { hidrográficas. Além } \\
\text { disso, elabora estudos e } \\
\text { projetos relativos ao } \\
\text { aproveitamento total } \\
\text { dos recursos hídricos }\end{array}$ & $\begin{array}{l}\text { (8) Diretorias de Bacias do } \\
\text { DAEE } \\
\text { Obs.: } 0 \text { município de Suzano } \\
\text { é atendido pela diretoria de } \\
\text { Mogi das Cruzes }\end{array}$ & $\begin{array}{l}\text { Realizar o monitoramento } \\
\text { dos reservatórios na região } \\
\text { do Alto Tietê Cabeceiras, os } \\
\text { quais possuem múltiplas } \\
\text { funções, como, por } \\
\text { exemplo, a regularização } \\
\text { de vazões e o controle das } \\
\text { enchentes }\end{array}$ & \\
\hline
\end{tabular}




\begin{tabular}{|c|c|c|c|c|c|}
\hline $\begin{array}{c}\text { Recorte } \\
\text { Territorial }\end{array}$ & Orgãos Gestores & Funções & Órgãos vinculados & Funções & Ações \\
\hline \multirow[t]{2}{*}{ Estado } & $\begin{array}{l}\text { DAIA - } \\
\text { Departamento de } \\
\text { Avaliação de } \\
\text { Impacto Ambiental }\end{array}$ & $\begin{array}{l}\text { Analisar os estudos } \\
\text { ambientais de } \\
\text { empreendimentos } \\
\text { sujeitos ao } \\
\text { licenciamento com } \\
\text { Avaliação de Impacto } \\
\text { Ambiental }\end{array}$ & $\begin{array}{l}\text { (7) Diretorias } \\
\text { (2) Divisões }\end{array}$ & $\begin{array}{l}\text { Definir diretrizes para a } \\
\text { recuperação de áreas } \\
\text { degradadas por atividades } \\
\text { humanas }\end{array}$ & $\begin{array}{l}\text { Emite parecer técnico que } \\
\text { subsidia o licenciamento } \\
\text { ambiental pela Secretaria de } \\
\text { Meio Ambiente - SMA, } \\
\text { define o Termo de Referência } \\
\text { para a elaboração do EIA e } \\
\text { RIMA e responde a consultas } \\
\text { sobre necessidade de } \\
\text { licenciamento ambiental }\end{array}$ \\
\hline & $\begin{array}{l}\text { SMA - Secretaria } \\
\text { Estadual do Meio } \\
\text { Ambiente }\end{array}$ & $\begin{array}{l}\text { Planejar, coordenar, } \\
\text { supervisionar, executar e } \\
\text { controlar as atividades } \\
\text { setoriais, que visem a } \\
\text { proteção, conservação e } \\
\text { melhoria do meio } \\
\text { ambiente, através da } \\
\text { execução das políticas } \\
\text { estaduais de Meio } \\
\text { Ambiente }\end{array}$ & $\begin{array}{l}\text { CETESB - Companhia } \\
\text { Estadual do Estado de São } \\
\text { Paulo (Agência Ambiental de } \\
\text { Mogi das Cruzes) }\end{array}$ & $\begin{array}{l}\text { Promover a unificação do } \\
\text { licenciamento ambiental } \\
\text { na região do Alto Tietê } \\
\text { Cabeceiras }\end{array}$ & $\begin{array}{l}\text { Implantar o licenciamento } \\
\text { ambiental unificado, bem } \\
\text { como fiscalizar as infrações } \\
\text { ambientais, na região do Alto } \\
\text { Tietê Cabeceiras }\end{array}$ \\
\hline Município & $\begin{array}{l}\text { Prefeitura Municipal } \\
\text { de Suzano }\end{array}$ & $\begin{array}{l}\text { implantar, } \\
\text { regulamentar e fiscalizar } \\
\text { as políticas públicas } \\
\text { referentes ao território } \\
\text { de Suzano }\end{array}$ & $\begin{array}{l}\text { Secretarias municipais: Meio } \\
\text { Ambiente; Infraestrutura e } \\
\text { Obras; } \\
\text { Política Urbana; } \\
\text { Manutenção e Serviços } \\
\text { Urbanos; Cultura; Segurança } \\
\text { Alimentar e Nutricional e de } \\
\text { Agricultura e Abastecimento, } \\
\text { entre outras }\end{array}$ & $\begin{array}{l}\text { Desenvolver políticas que } \\
\text { promovam: a recuperação } \\
\text { e manutenção de áreas de } \\
\text { proteção permanente e de } \\
\text { mananciais; o } \\
\text { planejamento, o } \\
\text { gerenciamento e a } \\
\text { execução de obras } \\
\text { públicas; o direito à cidade } \\
\text { sustentável; a formulação } \\
\text { de projetos e programas } \\
\text { voltados às ações de } \\
\text { manutenção e } \\
\text { aperfeiçoamento dos } \\
\text { serviços relacionados à } \\
\text { manutenção da cidade; a } \\
\text { elaboração, coordenação e } \\
\text { execução de projetos } \\
\text { capazes de garantir o } \\
\text { acesso aos bens culturais; a } \\
\text { elaboração de políticas } \\
\text { públicas capazes de } \\
\text { assegurar o acesso e } \\
\text { garantir o direito da } \\
\text { população à alimentação } \\
\text { de boa qualidade e de } \\
\text { baixo custo }\end{array}$ & $\begin{array}{l}\text { Desenvolver planos, projetos } \\
\text { e ações, além de } \\
\text { implementar e promover a } \\
\text { manutenção de obras e } \\
\text { serviços }\end{array}$ \\
\hline
\end{tabular}

Tabela criada por Michele de Sá Vieira, a partir de dados levantados junto aos órgãos estaduais e municipais, 2012 